BRUNO MITSUO NAGATA

\title{
FISCALIZAÇÃO FINANCEIRA QUANTO À LEGITIMIDADE
}

UNIVERSIDADE DE SÃO PAULO

Faculdade de Direito do Largo de São Francisco

SÃO PAULO

2012 
Bruno Mitsuo Nagata

\title{
FISCALIZAÇÃO FINANCEIRA QUANTO À LEGITIMIDADE
}

\author{
Dissertação apresentado à Faculdade de Direito da \\ USP como exigência para a obtenção do grau de \\ Mestre em Direito Econômico Financeiro e \\ Tributário.
}

Orientador: Prof. Estevão Horvath. 
BANCA EXAMINADORA 
Ao meu pai, José Mitsuo, pelo apoio incondicional registro minha eterna gratidão.

À minha mãe, Maria Alice, de saudosa memória, cuja lembrança é um perene incentivo para a determinação e a constância nos estudos acadêmicos. 


\section{AGRADECIMENTOS.}

Ao prof. Estevão Horvath pela confiança em mim depositada ao aceitar-me como seu orientando, rendendo-lhe, também, o meu reconhecimento pela sua generosa disposição em atender-me, não obstante seus laboriosos afazeres profissionais e acadêmicos.

Aos professores José Maurício Conti, Fernando Facury Scaff, Manoel Gonçalves e Odete Medauar pelas preciosas lições que nos foram passadas nas disciplinas do programa de pós-graduação da Faculdade de Direito da USP.

Ao prof. Régis Fernandes de Oliveira pelo apoio e incentivo que, certamente, foram fundamentais para alcançar os nossos objetivos acadêmicos.

Ao Dr. Sérgio Assoni Filho, exemplo de dedicação acadêmica, pelas oportunas críticas exaradas quando do exame de qualificação.

Aos meus pais, familiares e amigos pelo incentivo, apoio e auxílio. E, também, à Renata um especial agradecimento pela revisão profícua e minuciosa. 


\section{RESUMO}

A fiscalização financeira quanto à legitimidade tem fundamento constitucional expresso no art. 70 da CF de 1988. A sindicância da legitimidade cometida aos órgãos de controle interno e ao controle externo franqueia a possibilidade de verificar a correção material da atividade financeira do Estado. Todavia, essa atribuição constitucional não deixa de revelar alguma dificuldade aos órgãos de controle na medida em que dá condições para que se possa analisar o mérito das escolhas discricionárias. Assim, é preciso compatibilizar a fiscalização quanto à legitimidade com a preservação da discricionariedade, uma vez que não se admitem ingerências de um Poder sobre o outro. Ocorre que o sistema de controle é arquitetado de modo a garantir o exercício das faculdades discricionárias. Mediante controle externo, o Parlamento leva a efeito um controle dilatado e fluido garantindo a liberdade quanto às decisões políticas globais. O Tribunal de Contas, por sua vez, debruçase sobre a gestão administrativa constatando e coibindo qualquer vício quanto ao uso equivocado da discricionariedade. Já o controle interno da legitimidade não apresenta maiores problemas, pois nesse caso a Administração fiscaliza a si mesma, inexistindo ingerências indevidas.

Palavras - Chave:

Fiscalização. Controle Externo. Controle Interno. Legitimidade. Discricionariedade. 


\begin{abstract}
The financial control regarding the legitimacy is founded expressed in article 70 of the Brazilian Constitution of 1988. The inspection of legitimacy committed to the agencies of internal control and external control allows the possibility of verifying the substantial correctness of the public finances. However, this constitutional assignment causes some difficulties to control agencies in that it allows to examine the discretionary choices. Thus, it is necessary to reconcile the control of legitimacy with the preservation discretion, since it is not allowed the interference of a Power over the other. In fact, what happens is that the control system is architected to ensure the exercise of discretions. Through the external control, the Parliament carries out a less rigid control, ensuring freedom regarding the choices of political decisions. The County Court, in turn, focuses on the administrative action checking and preventing any defect on the mistaken exercise of discretion. Already the internal control of legitimacy presents no major problems, because in this case the Administration inspects herself, there is no undue interference.
\end{abstract}

Key-Words:

Surveillance. External Control. Internal Control. Legitimacy. Discretion. 


\title{
REFERÊNCIAS
}

\author{
ADI - Ação Direta de Inconstitucionalidade \\ CF - Constituição Federal \\ LRF - Lei de Responsabilidade Fiscal \\ MC - Medida Cautelar \\ MS - Mandado de Segurança \\ Resp - Recurso Especial \\ RO - Recurso Ordinário \\ STF - Supremo Tribunal Federal \\ STJ - Superior Tribunal de Justiça \\ TCE - Tribunal de Contas do Estado \\ TCU - Tribunal de Contas da União
}




\section{SUMÁRIO}

\section{INTRODUÇÃO.}

I - PERSPECTIVA CONSTITUCIONAL DO TEMA.

1. Constitucionalismo e Controle Financeiro.

2. Fiscalização e Controle.

3. Da Fiscalização Financeira.

4. Sistema Constitucional de Fiscalização Financeira.

5. Controle Externo e Interno.

$5.1 \mathrm{O}$ controle interno.

5.2. O controle externo.

5.2.1. O controle externo exercido pelo Congresso Nacional.

5.2.2. O controle externo exercido pelo Tribunal de Contas.

II - A NOÇÃO DE LEGITIMIDADE DO ART. 70 DA CF DE 1988.

1. Conceito de Legitimidade.

2. A Noção de Legitimidade preconizada pelo art. 70 da CF de 1988.

2.1. Legitimidade e Democracia.

2.2 Legitimidade e Interesse público.

2.3. Legitimidade e Moralidade.

2.4 Legitimidade e Legalidade.

2.5 Legitimidade e Economicidade.

3. A aferição da Legitimidade 


\section{III - FISCALIZAÇÃO FINANCEIRA QUANTO À LEGITIMIDADE.}

\section{Histórico.}

2. Problemática: a fiscalização da legitimidade e a invasão do mérito administrativo.

2.1. Discricionariedade política e discricionariedade administrativa.

2.2. Discricionariedade em matéria financeira e o regime orçamentário.

3. A Fiscalização Financeira quanto à Legitimidade mediante Controle Externo.

3.1. Os regimes de apuração das contas públicas: contas de governo e contas de gestão.

3.2. O controle da legitimidade e o Poder Legislativo.

3.3 O controle da legitimidade e o Tribunal de Contas.

3.3.1. Os limites da atuação dos Tribunais de Contas em relação aos atos discricionários.

3.3.2. O julgamento do Chefe do Executivo pelo Tribunal de Contas.

4. A Fiscalização Financeira quanto à legitimidade mediante Controle Interno.

5. A Fiscalização Financeira quanto à Legitimidade: as empresas estatais, as renúncias de receitas e as subvenções.

5.1 O controle de legitimidade e as empresas estatais.

5.2. O controle de legitimidade e as renúncias de receitas.

5.3. O controle de legitimidade e as subvenções.

SÍNTESE CONCLUSIVA.

REFERÊNCIAS BIBLIOGRÁFICAS.

JULGADOS. 


\section{INTRODUÇÃO.}

Na seara do controle das contas públicas, a Constituição Federal de 1988 trouxe ao ordenamento jurídico pátrio uma novidade sem precedentes na história jurídica nacional. A saber, os órgãos voltados à fiscalização financeira não mais se circunscrevem à apuração de regularidades formais, podendo aprofundar o exame das contas, visto que estão constitucionalmente habilitados a examinar a legitimidade relativa à condução das finanças públicas. Precisamente, o art. 70, caput, da Constituição inova ao possibilitar o contraste da legitimidade, superando a ordem jurídica então vigente, que permitia apenas uma sindicância de mera legalidade formal.

Mas, não obstante essa inolvidável competência, é espantoso verificar que a fiscalização financeira quanto à legitimidade é um dos temas mais negligenciados pelos doutrinadores pátrios. É bem verdade que os "Manuais" e os "Cursos" não se furtam em comentar o tema, todavia, o tratamento dispensado é, no mais das vezes, superficial ou não esgota a extensa problemática provocada com exercício do controle de legitimidade.

Pode-se afirmar, sem qualquer temeridade, que inexistem monografias específicas sobre o tema. Há, praticamente, um deserto doutrinário acerca da aferição de legitimidade pelos organismos de fiscalização das contas públicas, em que pese ser este um tema da maior relevância, sobretudo se considerada a tendência cada vez mais pujante da atuação desses órgãos, notadamente, o Tribunal de Contas.

Os últimos anos mostraram que os Tribunais de Contas têm procedido de maneira muito vigorosa, suscitando, por parte dos agentes políticos, críticas severas no sentido de que o aprofundamento do controle acaba por interferir negativamente nas prerrogativas gerenciais da Administração, bem como contribui para o atraso no oferecimento de bens e serviços públicos. Nesse contexto, uma análise detida da fiscalização quanto à legitimidade é um reclame indeclinável, uma vez que o controle desse aspecto leva a indagar sobre a correção material das finanças públicas, possibilitando o confronto direto da escolha de prioridades, de diretrizes e do modo como se gerencia a res pública. 
Como se nota, ao menos do ponto de vista da relevância do tema, não existem razões para se desprezar o estudo da fiscalização financeira quanto à legitimidade. Assim, o enfretamento do tema se faz imprescindível tanto para fundamentar um controle financeiro mais substancioso e efetivo, quanto para preservar as faculdades da Administração Pública no exercício de suas funções privativas.

Porém, uma reflexão mais analítica acerca do controle de legitimidade das finanças públicas levanta inúmeras dificuldades. O primeiro obstáculo a ser superado é, sem dúvida, o de encontrar a significação adequada da palavra legitimidade. Questiona-se o que seria uma atuação legítima, existindo, nesse particular, um plexo considerável de teorias e discussões. Alguns dizem que a atuação legítima é aquela que realiza a justiça, outros, que a legitimidade infere-se do assentimento democrático; ainda, há aqueles que defendem a legitimidade como a satisfação das necessidades públicas, desvinculando-a de qualquer apelo axiológico.

Assim, já no tocante à definição do sentido de legitimidade, aparecem discussões de alta indagação relativas à propedêutica jurídica e à filosofia, pois a perspectiva de correção acaba por provocar uma intrincada reflexão sobre a justificação daquilo que é certo em oposição ao errado. Em outras palavras, afirmar que uma ação é legítima importa em saber se ela é certa ou errada, boa ou má, justa ou injusta. Assim, este enfoque não prescinde de uma perquirição sobre o que é, de fato, o justo, o bom e o correto.

Ocorre, no entanto, que as dificuldades não se resumem simplesmente à complexa exegese filosófica e etimológica do vocábulo em tela. Na medida em que a fiscalização da legitimidade invoca a necessidade de correção material, as escolhas derivadas da discrição administrativa podem ser contraditadas quando não desvelarem o bem comum, superando-se, portanto, a sindicância de uma mera legalidade formal. Nessa esteira, o tema também participa de uma celeuma jurídica assaz obtusa, consistente na possibilidade de controlar os chamados atos discricionários.

Registre-se que a sindicabilidade da discricionariedade administrativa é um dos tópicos mais controvertidos do Direito Público, revelando preocupações das mais prudentes, tais como: a imunidade quanto às ingerências de um Poder sobre outro; a questão da identificação da competência discricionária; e, por fim, a possibilidade de revisão do mérito do ato discricionário diante do uso viciado da margem de liberdade. Logo, o estudo do controle da legitimidade não pode se dar sem um esforço intelectivo que 
demonstre todo o embate jurídico ligado ao esclarecimento do controle da discricionariedade, suas limitações e peculiaridades.

Nessa perspectiva, o estudo do controle de legitimidade não pode se furtar em analisar o conteúdo do mérito administrativo e das condições em que é possível sindicá-lo, bem como não poderá olvidar-se de fundamentar a habilitação constitucional dos órgãos de controle financeiro para rever as escolhas derivadas da discrição administrativa. Sem esquecer, é claro, que toda a argumentação vertida em favor do controle da discricionariedade deve, compulsoriamente, ponderar a imperiosa necessidade de resguardar as faculdades discricionárias da Administração Pública.

Mas além de toda a dificuldade já exposta, o estudo da fiscalização financeira quanto à legitimidade deve enfrentar, ainda, a análise dos mecanismos institucionais pelos quais essa espécie de controle se operacionaliza. Em outros termos, é preciso desvendar a atribuição constitucional dos órgãos de controle das contas públicas para reconhecer como a legitimidade pode ser aferida na prática. Nota-se que a Constituição estabelece uma pluralidade de organismos fiscalizatórios, dotando-os com atribuições precisas e, ao mesmo tempo, distintas; assim, conforme a natureza do ente controlador, a averiguação da legitimidade assume certas peculiaridades que precisam ser pontuadas.

Vale sublinhar, diante desse breve panorama, o quão árduo e complexo é o estudo do controle financeiro quanto à legitimidade. Nesse sentido, é preciso, desde logo, estabelecer algumas delimitações ao tema proposto, sendo o seu enquadramento objetivo extraído, necessariamente, da sistemática constitucional. Conforme foi consignado, a fiscalização financeira quanto à legitimidade está explicitamente prevista na Lei Maior, mais precisamente no art. 70, caput. Desse modo, as balizas que orientarão o enfrentamento do tema decorrerão do quadro constitucional no qual a análise de legitimidade está inserida.

Topologicamente, a fiscalização de legitimidade está inscrita na seara referente ao controle das contas públicas e, nos termos da Constituição, essa sindicância será exercitada mediante controle externo e interno. $\mathrm{O}$ controle externo é aquele realizado pelo Poder Legislativo, auxiliado, nesse mister, pelo Tribunal de Contas. Noutro lado, o controle interno, por sua vez, é efetivado por cada Poder sobre suas próprias estruturas, sendo o controle realizado por cada Poder sobre si mesmo. 
Ocorre, assim, que essas duas espécies de controle, o interno e o externo, levam a cabo a sindicância de legitimidade, de modo que o estudo do tema não pode fugir dessas balizas constitucionais. Ou seja, o tema proposto será enfrentado, obrigatoriamente, dentro da ótica do controle interno e do controle externo, uma vez que a própria Constituição concebe a fiscalização de legitimidade sob o influxo desses dois tipos de controle.

Estabelecida essa premissa metodológica, vale ressaltar que o estudo a ser empreendido não fará referência ao controle que o Poder Judiciário exerce sobre a atuação financeira do Estado. Na mesma linha, não será abordado o questionamento relativo aos mecanismos do chamado controle social. Não se despreza, é evidente, a importância dos controles judicial e social, todavia, a complexidade do tema requer uma delimitação mais restrita, de maneira que o enfretamento da fiscalização de legitimidade será circunscrito tendo em vista a perspectiva constitucional expressa - às formas institucionais do controle externo e do controle interno.

Destarte, o estudo que segue a essa breve introdução está dividido em três grandes partes. A primeira analisa o sistema de fiscalização financeira sob o ângulo constitucional, uma vez que a aferição da legitimidade está no interior de uma estrutura orgânica de controle definida pela Lei Maior.

A segunda parte examina o conceito de legitimidade. O objetivo é esclarecer o conteúdo semântico da "legitimidade" a ser apurada pela fiscalização financeira. Essa análise verificará a carga axiológica expressa pelo vocábulo e sua aproximação com a idéia de justiça, problematizando, também, a relação da legitimidade com a participação democrática, o interesse público, a moralidade e, também, com os aspectos da legalidade e da economicidade.

Por fim, a última parte verifica a procedimentalização da fiscalização financeira quanto à legitimidade mediante controle externo e interno. O cerne dessa análise está na aferição do controle do mérito administrativo por parte do Tribunal de Contas e do Poder Legislativo. Nesse particular, avalia-se em que medida os órgãos de controle podem invadir os critérios de conveniência e oportunidade que orientaram a direção da atividade financeira do Estado. 


\section{I - PERSPECTIVA CONSTITUCIONAL DO TEMA.}

\section{CONSTITUCIONALISMO E CONTROLE FINANCEIRO.}

A CF de 1988 dedica uma seção específica para regular a fiscalização da atividade financeira do Estado. Inserida no capítulo referente à organização do Poder Legislativo, a seção intitula-se "Da fiscalização contábil, financeira e orçamentária" e compreende os arts. 70 a 75 da Constituição Federal.

É de se notar que os dispositivos que figuram nessa seção específica arquitetam a configuração elementar da fiscalização das finanças públicas, não esgotando, todavia, a extensa temática que comporta o controle financeiro do Estado. Como se verificará adiante, a leitura sistemática do Texto Maior permite identificar preceitos constitucionais voltados ao controle das contas públicas, que, por sua vez, não estão presentes na seção própria "Da Fiscalização contábil, financeira e orçamentária".

Mas antes de analisar a fiscalização das finanças públicas tal como disciplinada na Constituição, cabe fazer alguma ponderação sobre os motivos histórico-políticos que induziram o constituinte a alçar ao status constitucional a matéria afeita ao controle da atividade financeira do Estado. Ou seja, busca-se compreender o controle financeiro do Estado sob a perspectiva do constitucionalismo.

É imperioso destacar que a idéia de constitucionalismo está intimamente vinculada à noção de limitação de poder dos governantes. Mc Ilwain, em sua obra Constitutionalism: Ancient and Modern ${ }^{1}$, faz uma análise da história política dos povos que influenciaram a cultura ocidental, indicando que: "o constitucionalismo tem uma qualidade essencial: é uma limitação jurídica imposta ao governo; é a antítese do governo arbitrário; seu oposto é o governo despótico, o governo da vontade ao invés do império da lei." 2

\footnotetext{
${ }^{1}$ Cf. MC ILWAIN, Charles Howard.. Constitucionalismo Antiguo y Moderno. Trad. José Rovira Armenegol. Buenos Aires: Editorial Nova, 1947.

2 "el constitucionalismo tiene una cualidad esencial: es una limitación jurídica impuesta al gobierno; es la antítesis del gobierno arbitrario; su opuesto es el gobierno despótico, el gobierno de la voluntad en vez del imperio de la ley.'Ibid. p. 35.
} 
Manoel Gonçalves Ferreira ${ }^{3}$, embasado na citada obra de Mc Ilwain, afirma que o fator essencial do constitucionalismo, seja ele antigo ou moderno, não se resume na implantação de uma Constituição escrita, sendo seu intento primordial a limitação do poder. Prossegue o citado autor, lecionando que o constitucionalismo moderno movimento jurídico-político surgido nos fins do século XVIII - reclama não só a adoção de Constituições documentais, mas também que essas Constituições imponham uma organização limitativa do poder com o desiderato de impedir arbítrios.

Clara afirmação desse nascente constitucionalismo está plasmada no art. 16 da Declaração dos Direitos do Homem e do Cidadão de 1789 que proclama: “Qualquer sociedade em que não esteja assegurada a garantia dos direitos, nem estabelecida a separação dos poderes não tem Constituição.” Interessa notar que a idéia de Constituição não se faz completa tão somente com a proclamação de direitos e garantias individuais. Exige-se, também, que o diploma constitucional disponha sobre a separação de poderes. $\mathrm{O}$ esquema da divisão de poderes implica em definir a competência dos órgãos estatais, organizando a distribuição de poder dentro do Estado com o claro intuito de limitar o exercício do poder. ${ }^{4}$

Desse modo, é natural encontrar elementos de organização do poder no seio das Constituições. Antes, as normas constitucionais que operam a divisão de poderes fazem parte daquilo que se convencionou chamar de Constituição material. Ou seja, os fatores que importam na limitação do poder estatal são matérias de cunho essencialmente constitucional e, portanto, aptas e necessárias a figurar em um diploma que se propõe conformador da estrutura política do Estado.

A dicotomia entre Constituição material e formal consagrou-se na doutrina tradicional. Nesse sentido, leciona José Afonso da Silva:

"Segundo a doutrina tradicional, as prescrições das constituições que não se referiam à estrutura do Estado, à organização dos poderes, seu exercício e aos direitos do

\footnotetext{
${ }^{3}$ FERREIRA FILHO, Manoel Gonçalves. Princípios Fundamentais do Direito Constitucional. $2^{\mathrm{a}}$ ed. São Paulo: Saraiva, 2010. p. 3 e 4.

${ }^{4}$ Nesse sentido aponta Manoel Gonçalves: "A Constituição deve dispor sobre a organização política do Estado, nos seus traços basilares, definindo os seus órgãos de cúpula, discriminando-lhes a competência, fixando os limites de sua atuação legítima. É o que sugere Montesquieu no Espírito das Leis, ao dissertar sobre os Poderes, e corrobora o art. 16 da Declaração de 1789 na referência à 'separação de poderes'." Ibid. p.24.
} 
homem e respectivas garantias, só são constitucionais em virtude da natureza do documento a que aderem; por isso, diz-se que só são constitucionais apenas do ponto de vista formal." 5 (destaque do autor).

Conforme se denota das lições de José Afonso da Silva, a chamada Constituição material contempla um núcleo de natureza essencialmente constitucional que consiste na organização dos poderes e na previsão de direitos e garantias. Tal núcleo essencial, embora fruto histórico do constitucionalismo nascido no século XVIII, ainda figura como elemento presente nas Constituições hodiernas. A preocupação em organizar o exercício do poder, com a sua conseqüente limitação, é tarefa da qual o poder do constituinte de qualquer época não pode se furtar.

Jorge Miranda afirma que: "No século XX a Constituição material sofre duas vicissitudes decisivas: generaliza-se, universaliza-se; e, simultaneamente, perde a sua referência liberal." 6 O autor esclarece que a Constituição deixa de se preocupar com as liberdades individuais e a separação de poderes para inserir no âmbito constitucional os direitos sociais, econômicos e culturais ou atribuir diferentes tarefas ao poder político. Contudo, não obstante haja um alargamento do objeto da Constituição, em desprestígio à idéia tradicional de Constituição material, não se pode deixar de reconhecer a natureza constitucional das disposições que regulam a organização do poder estatal. O próprio constitucionalista lusitano reconhece que: "Na realidade qualquer Constituição encerra elementos orgânicos e doutrinais." 7 Ou seja, qualquer Constituição encerra em seu conteúdo aspectos relativos à organização do poder e normas que revelam o interesse do constituinte em cuidar da vida social, econômica e cultural.

Sobre o caráter notadamente constitucional das regras de organização do poder, advoga, ainda, a doutrina de Antonino Spadaro $^{8}$, aludindo que toda contemporânea Constituição contém essencialmente dois grupos de normas: aquelas relativas a "princípios ideais" na qual é inspirada a convivência civil e aquelas atinentes à organização do aparato

\footnotetext{
${ }^{5}$ SILVA, José Afonso. Curso de Direito Constitucional Positivo. 23 ed. São Paulo: Malheiros, 2005. p.43.

${ }^{6}$ MIRANDA, Jorge. Manual de Direito Constitucional. Tomo II. $2^{\mathrm{a}}$ ed. Coimbra: Coimbra Ed., 2005. p 20.

${ }^{7}$ Ibid. p. 24.

${ }^{8}$ Segundo Spadaro: "ogni moderna Costituzione contiene essenzialmente due gruppi di norme: quelle relative ai 'principi ideali' cui è ispirata La convivenza civile e quelle attinenti all 'organizzazione dell'apparato statale" SPADARO, Antonino. "Contributo per una Teoria della Costituzione: fra democrazia relativista e assolutismo etico". V I. Milano: Giufré, 1994. p. 62.
} 
estatal. Esse autor italiano formulou uma tripartição conceitual da noção de Constituição a partir de constantes essenciais evidenciadas por uma pluralidade de teorias, afirmando que a Constituição democrática é: a) uma tábua de valores fundamentais, concebidos com o complexo de valores políticos, éticos, religiosos e econômicos que o poder constituinte houve por bem constitucionalizar; b) um conjunto de regras do jogo político, havendo, desse modo, disposições constitucionais referentes à formação da vontade política; e c) um sistema de limites jurídicos essenciais. ${ }^{9}$

Sobre o sistema de limites jurídicos essenciais leciona Antonino Spadaro:

“A Constituição, assim, mostra-se essencialmente como um 'código jurídico' que - repartindo poderes, atribuições e competências entre os principais sujeitos do ordenamento põe limites essenciais, estáveis (e, às vezes, imodificáveis) à ordenação da convivência social." 10

Nota-se, portanto, que a separação de poderes, com a conseqüente determinação de competências e atribuições dos órgãos estatais, tem uma razão de ser, qual seja, a limitação do poder do Estado frente aos indivíduos. O simples fato de a Constituição operar a divisão funcional do poder, consagrando a clássica doutrina de Montesquieu, impede, por si só, a concentração de poder nas mãos de um único órgão. Ademais, essa decomposição do poder entre as funções típicas do Estado - levando assim à denominação do Poder Legislativo, Poder Executivo e Poder Judiciário - desdobra-se em um sistema de freios e contrapesos em que a atribuição de competência a um órgão limita e contém o exercício do poder conferido ao outro. ${ }^{11}$

Nessa perspectiva, conclui-se que a separação dos poderes é fator preponderante na limitação do poder estatal, razão pela qual possui um evidente status constitucional, pois o intento da contenção do poder é escopo atemporal do constitucionalismo.

\footnotetext{
${ }^{9}$ SPADARO, Antonino. Contributo... p. 54 e 55.

${ }^{10}$ Ibid. p. 55. "La Costituzione, dunque, appare essenzialmente come un "códice giuridico che - ripartendo poteri, atribuizioni e competenze fra i principali soggetti dell'ordinamento - pone limiti essenziali, stabili (e, talvolta, immodificabili) all'ordinata convivenza sociale”,

${ }^{11}$ Segundo José Afonso da Silva a harmonia entre os poderes verifica-se quando entre eles "há de haver consciente colaboração e controle recíproco (o que, aliás, integra o mecanismo) para evitar distorções e desmandos." SILVA, José Afonso. Curso... p. 111.
} 
Quanto ao status constitucional do controle financeiro do Estado deve-se reconhecer de pronto que esse tipo de controle possui um caráter notadamente limitativo. Talvez, nos dias que correm, o aspecto financeiro seja o fator de maior relevância para o incremento do poder estatal, logo, qualquer disposição que venha a regular ou restringir a atividade financeira do Estado mereceria, por si só, o status constitucional. No entanto, a essência constitucional do controle financeiro do Estado está ligada ao esquema de separação de poderes, pois concentrar toda atividade financeira nas mãos de um único Poder vai de encontro à proposta de limitação do poder preconizada pelo constitucionalismo. Logo, a estruturação orgânica dos Poderes reclama, também, uma divisão das competências e atribuições no âmbito da atividade financeira.

Ressalte-se, nesse sentido, que toda a temática voltada à distribuição de competência e atribuições em matéria financeira consta, obrigatoriamente, como parte integrante da chamada Constituição material. Efetivamente, o desenho institucional da tripartição de poderes evidencia e determina quem são órgãos responsáveis e quais as suas respectivas atribuições na condução da atividade financeira do Estado, sendo certo, também, que essa organização desdobra-se em um sistema de freios e contrapesos pelo qual a competência deferida a um Poder limita e refreia a atuação dos demais Poderes.

Sem dúvida, essa composição orgânica dos Poderes no tocante à atividade financeira do Estado acaba por conceber um sistema constitucional de controle das finanças públicas. Nesse sentido, vale consignar que as competências dos Poderes em relação a esse sistema estão, em larga medida, alicerçadas em um instrumento histórico de contenção do poder financeiro do Estado: o orçamento. Nas lições de Alvaro Rodriguez Bereijo:

"O orçamento é a instituição na qual historicamente se há plasmado as lutas políticas das representações populares (Parlamentos, Assembléias, Dietas, Cortes) por conseguir o direito de fiscalizar e controlar o exercício do financeiro: primeiro em relação à imposição de tributos e encargos e, 
posteriormente, em relação à administração das receitas $e$ distribuição dos gastos públicos." 12

Precisamente, o regime constitucional orçamentário exige uma interação necessária entre Executivo e Legislativo para que a atividade financeira do Estado possa se desenvolver a contento. $\mathrm{O}$ orçamento, sob a ótica do procedimento constitucional que envolve sua elaboração, aprovação e execução, manifesta-se como evidente fator de controle financeiro, pois exige que a atividade de designar os gastos públicos e indicar as receitas correspondentes seja compartilhada pelos Poderes Executivo e Legislativo.

Roberto Dromi ${ }^{13}$, de seu turno, afirma que o orçamento é uma manifestação do controle jurídico-político do Poder Legislativo sobre o Executivo, em atenção à repartição de competências em matéria financeira, sendo que tal repartição de competências dependeria de um regime constitucional concreto.

Das lições de Roberto Dromi destacam-se dois pontos fundamentais: o primeiro liga-se ao fato de que, através do orçamento, o Legislativo exerce o controle sobre o Executivo em matéria financeira; e o segundo é relativo à idéia de que a repartição de competências dos Poderes em matéria financeira depende de um regime constitucional concreto.

No tocante ao primeiro ponto, constata-se que o controle do Legislativo sobre o Executivo em matéria financeira remonta a uma antiga tradição política. Manoel Gonçalves $^{14}$ afirma que o controle financeiro do Legislativo é anterior à própria função legislativa, encontrando respaldo na Magna Carta de 1215 que consagra princípio pelo qual

\footnotetext{
12 BEREIJO, Alvaro Rodriguez. “Estudio preliminar”. In: LABAND, Paul. “Derecho presupuestario”. Madri: Instituto de Estudios Fiscales, 1979. p. XI. "El Presupuesto es la institución en que historicamente se han plasmado las luchas políticas de las representaciones populares (Parlamentos, Assembleas, Dietas, Cortes) por conseguir el derecho a fiscalizar y controlar el ejercicio del poder fianaceiro: primero respecto de la imposicion de tributos y cargas y, posteriormente, respecto a la administración de los ingressos y distribuición de los gastos públicos."

${ }^{13}$ DROMI, Jose Roberto. "Constitución, Gobierno y Control” Argentina: Ediciones Ciudad Argentina, 1983. p. 200. Segundo ele: "El pressupuesto es una manifestación del control jurídico-político del Poder 'Legislativo' sobre el 'Ejecutivo', (...). El pressupuesto objetiva la relación jurídico-política entre el Parlamento y Poder Ejecutivo, respecto del reparto de competencias en materia financiera, que depende del régimen constitucional concreto."

14 "Na verdade, o poder financeiro das Câmaras é historicamente anterior ao exercício, por elas, da função legislativa. De modo geral, as câmaras representativas da Idade Média, destinavam-se precipuamente a consentir nos impostos, em razão do princípio largamente difundido de que sem o consentimento dos contribuintes ou de seus representantes não pode haver cobrança de tributos, princípio esse, por exemplo, consagrado na Magna Carta" FERREIRA FILHO, Manoel Gonçalves. Curso de Direito Constitucional. 30 ed. São Paulo: Saraiva, 2003. p. 158.
} 
a instituição de tributos deve ser consentida pelo Parlamento. Igualmente, José Afonso da Silva ${ }^{15}$ preleciona que o controle da administração financeira é um conquista secular do Poder Legislativo, sendo certo que a esse Poder deve pertencer a prerrogativa de controlar o aspecto financeiro do Executivo.

De outra parte, é imperioso reconhecer que o modo de ser do controle financeiro depende de um regime constitucional concreto que indique os entes responsáveis pelo controle, definindo, igualmente, suas respectivas atribuições e competências. Nessa linha, o constituinte brasileiro de 1988, ao compor o esquema da tripartição de poderes, houve por bem, em atenção à tradição política, atribuir a titularidade do controle financeiro do Estado ao Poder Legislativo. ${ }^{16}$

A análise do Diploma Constitucional pátrio indica que a disciplina do controle financeiro não se dirige apenas à temática orçamentária. Embora se prestigie a adoção do orçamento como instrumento de contenção do poder financeiro, impende verificar que o constituinte também dotou o Poder Legislativo de uma função sindicante que ultrapassa a clássica atribuição legislativa de avaliar e aprovar a proposta orçamentária desenhada pelo Executivo.

Mais uma vez, com base na doutrina de Roberto Dromi ${ }^{17}$, pode-se dizer que o orçamento é um instrumento "de" controle e "para" o controle. O autor refere-se ao fato de que orçamento presta-se não só a controlar a previsão e a arrecadação dos gastos, mas também serve de base para o cotejo dos gastos concretamente efetuados com a previsão inicialmente determinada.

Argumenta-se, nesse sentido, que cabe ao Legislativo exercitar um controle " $a$ posteriori", pois de nada adiantaria aprovar - em alguns casos, até emendar - o orçamento, se posteriormente não se pudesse comprovar a regularidade das despesas efetivamente realizadas.

Corrobora na argumentação a doutrina de Francesc Vallés Vives ${ }^{18}$, para quem o papel que corresponde ao Legislativo não se limita a autorizar a previsão de gastos pelo

\footnotetext{
${ }^{15}$ SILVA, José Afonso. Curso ... p.731.

${ }^{16}$ A teor do art. 166 da CF de 1988, cabe ao Congresso Nacional apreciar, emendar e votar os projetos de lei orçamentária. Ainda, nos termos do art. 70 da Constituição, cabe ao Congresso Nacional, mediante controle externo, a fiscalização operacional, patrimonial, financeira e orçamentária da União e das entidades de administração direta e indireta.

${ }^{17}$ DROMI, Jose Roberto. Constitución... p. 200.

18 VIVES, Francesc Vallés. El control externo del gasto público: configuración y garantía constitucional Madrid:Centro de Estudios Políticos y Constitucionales, 2003. p. 32. Diz o autor: "el papel que corresponde al Legislativo no consiste únicamente en determinar la previsión de gastos autorizada anualmente (mediante
} 
orçamento, mas, sobretudo, cabe ao Parlamento comprovar como o gasto foi definitivamente concretizado.

Logo, o controle financeiro pelo Legislativo que se contente apenas em aprovar o orçamento não será efetivo e completo, minando todo o intento de limitação do poder desejado com a instituição do controle constitucional da atividade financeira do Estado.

Considerando que as feições institucionais do controle financeiro do Estado dependem de um regime constitucional concreto, conclui-se que o constituinte da CF de 1988 não se contentou em controlar a atividade financeira do Estado apenas por meio da técnica de apreciação e aprovação orçamentária. A CF de 1988 foi além, atribuindo ao Poder Legislativo a prerrogativa de fiscalizar a concretização dos gastos públicos, bem como quaisquer outros ônus patrimoniais que possam acometer as finanças estatais.

Desse modo, o controle financeiro preconizado pela CF de 1988 possui um caráter duplamente limitativo. De um lado, cabe ao Poder Legislativo avaliar e aprovar o projeto orçamentário encaminhado pelo Executivo, autorizando a realização dos gastos contemplados no orçamento. De outro lado, o Poder Legislativo possui uma atribuição sindicante que contrasta os atos de disposição patrimonial e financeira em face de elementos de correção propostos pela ordem jurídica.

la aprobación de la Ley de pressupuestos); (...) Sino tambien y sobre todo, em comprobar como éste há sido definitivamente gastado." 


\section{FISCALIZAÇÃO E CONTROLE.}

Os vocábulos "físcalização" e "controle" podem ser compreendidos como sinônimos, sendo empregados indiscriminadamente. No entanto, um olhar mais atento sobre a sindicância da atividade financeira do Estado revela que "fiscalização" e "controle" podem expressar significados distintos, razão pela qual merecem alguma exegese semântica.

Fábio Konder Comparato ${ }^{19}$ aponta que a palavra "controle" é de origem francesa, sendo um neologismo no idioma português. Por outro lado, o autor esclarece que o sentido vernacular de "controle" sofreu forte influência do inglês.

Partindo da origem francesa, o termo "controle" procede da palavra "contrôle". No idioma francês, "contrôle" formou-se a partir da locução "contre-rôle" que, segundo Odete Medauar, seria o "registro que efetua o confronto com o registro original e serve para verificar os dados". ${ }^{20}$ Assim, "contrôle", na acepção gálica, exprime uma idéia de averiguação ou exame que se realiza para verificar a correção. No vernáculo, a palavra "controle" pode assumir a mesma significação francesa, sendo também compreendida como verificação, exame e contraste. Com esse valor semântico, a palavra "controle" seria sinônimo de fiscalização.

Para Geraldo Ataliba, "Fiscalizar consiste em contrastar - para averiguar de sua adequação - uma atividade com as normas que a disciplinam." ${ }^{21}$ Nesse sentido, as palavras "fiscalizar" e "controlar" podem ter sentidos idênticos, assumindo o significado de uma atividade material concreta de verificação que - mediante contraste com o padrão de correção eleito - visa constatar qualquer desvio ou incorreção.

Contudo, embora "controle" e "fiscalização" possam ser apreendidos como sinônimos, sendo usados indistintamente, é preciso reconhecer que a palavra "controle" pode expressar um significado próprio que se afasta da mera idéia de exame, contraste ou

\footnotetext{
${ }^{19}$ COMPARATO, Fábio Konder. O poder de controle na sociedade anônima. $2^{\mathrm{a}}$ ed. São Paulo:RT, 1977. p. 11 e 12.

${ }^{20}$ MEDAUAR, Odete. Controle da Administração Pública. São Paulo: RT, 1993. p.13.

${ }^{21}$ ATALIBA, Geraldo. Extensão do conceito de bem público para efeito de controle financeiro interno e externo. Revista de Informação Legislativa, Brasília, Ano. 22, nº 86. Abr/jun, 1985. p. 283.
} 
verificação. Essa particularidade de sentido para o termo "controle" deve-se à influência do inglês na formação semântica da palavra.

Na língua anglo-saxônica, o verbo "to control" tem sua significação ligada à idéia de direção, autoridade e dominação. "To control" aproxima-se de "to conduct", significando, desse modo, uma ação tendente a orientar, conduzir ou dirigir. ${ }^{22}$ Já o paralelo de "físcalização" na língua inglesa é "to check" que pode ser traduzido em português por inspecionar, verificar e revisar. ${ }^{23}$

Ainda, importa consignar que a concepção inglesa da palavra "controle" não pressupõe, necessariamente, que o ato de dirigir ou orientar recaia sobre uma terceira pessoa, uma vez que grassa na língua inglesa a palavra "selfcontrol", ou seja, "controle sobre si mesmo". Logo, o destinatário e o emissor da orientação ou direção podem se confundir, não se exigindo que sejam entes distintos.

Com base no exposto, não se pode deixar de reconhecer o papel da língua inglesa na composição semântica da palavra "controle", de modo que "controlar" exprime, também, o significado de orientar, dirigir ou direcionar, distinguindo-se da noção de "fiscalização". Assim, o emprego do verbo "controlar" pode referir-se a uma ação consistente em orientar ou dirigir o comportamento próprio ou de outrem, determinando-o para um fim específico. Fala-se, nesse senso, em "controle da razão sobre a emoção", "controle do empregador sobre o empregado", "controle da inteligência sobre a vontade", etc.

No particular das finanças públicas, "físcalização" e "controle" podem ser usados como sinônimos, ou a palavra "controle" pode assumir um significado próprio afeito à idéia de direção, orientação ou condução.

Francesc Vallés Vives bem ilustra as possibilidades de uso das palavras "fiscalização" e "controle", ao dispor que:

"podemos utilizar ambos os termos, fiscalização e controle, indistintamente sempre e quando outorgarmos ao conceito genérico de controle um sentido mais ajustado à idéia de fiscalização; é dizer o termo controle deve, necessariamente,

\footnotetext{
${ }^{22}$ COMPARATO, Fábio Konder. O poder... p. 11.

${ }^{23}$ VIVES, Francesc Vallés. El control ... p. 213
} 
ser entendido como aquela atividade de comprovação de regularidade em face de parâmetros previamente estabelecidos." 24

Sobre o termo "controle" no sentido de direção, condução, ou orientação, diz o citado autor:

"O conceito de controle pode caracterizar em termos jurídicos e políticos como a atividade parlamentar voltada (mediante uma pluralidade de mecanismos) à correção da atividade do poder Executivo e à verificação de sua adequação a parâmetros estabelecidos pelo próprio Parlamento, sendo que a atividade de controle é capaz de produzir conseqüências diversas, dentre elas a exigência de responsabilidade jurídica do Governo, gerando, eventualmente, uma influência sobre o comportamento do sujeito controlado. ${ }^{25}$

Esse último excerto expõe que o controle parlamentar é hábil a produzir uma influência sobre o comportamento do Executivo. Desse modo, é imperioso reconhecer que a influência exercida pelo ente controlador acaba por ditar uma orientação e um direcionamento ao sujeito controlado, revelando o sentido singular ao termo "controle" que não é, simplesmente, o de fiscalização.

Ao mesmo tempo, verificar que a atuação do sujeito controlador é apta a conferir algum direcionamento à atuação do controlado acaba por atrelar a noção de fiscalização à de controle, mesmo quando esses vocábulos não se apresentam como

\footnotetext{
${ }^{24}$ VIVES, Francesc Vallés. "El control ... p. 213. "podemos utilizar ambos términos, fiscalización y control, indistintamente siempre y cuando otorguemos al concepto genérico de control más ajustado al término fiscalización; es decir el término control debe necessariamente ser entendido como aquella atividad de comprobación de la actuación a unos parámetros previamente establecidos"

${ }^{25}$ Ibid. p. 214. "El concepto de control, se puede caracterizar em términos jurídicos y políticos, como aquella actividad parlamentária encaminada (mediante uma pluralidad de mecanismos), a la comprobación de la actividad del poder Ejecutivo y a la verificacion de su adecuación a los parámetros estabelecidos por el Parlamento, susceptibles de producir consecuencias diversas, y entre, ellas, la exigencia de responsabilidad jurídica del Gobierno, y eventualmente generadora de una influencia variable sobre el comportamiento del sujeto controlado”
} 
sinônimos. Nessa linha Ricardo Lobo Torres, reconhece que: "A fiscalização financeira se faz por meio de controle, de modo que os dois conceitos se tornam amplamente coincidentes e imprecisos." ${ }^{26}$ Isso porque, no âmbito das finanças públicas, a fiscalização exercida pelos órgãos e entes competentes termina por influir na orientação da atividade financeira do Estado, pois, conforme anota Rodrigues Martins, "a fiscalização levada a efeito, tanto pelo poder público, quanto pelo cidadão, não tem somente o caráter de aferição, mas principalmente de monitoração e correção dos atos praticados pela Administração Pública." 27

Assim, o ato de fiscalizar imprime, também, um controle - significando orientação e direcionamento -, pois averiguar a adequação de condutas traz conseqüências diretas ou indiretas que, de alguma maneira, determinam a orientação da atividade financeira do Estado.

O constituinte da CF de 1988, no que tange às finanças públicas, observou as nuances semânticas relativas aos termos "físcalização" e "controle", relacionando-os de modo a estabelecer uma estreita ligação entre eles. O art. 70 da CF de 1988 faz menção à fiscalização financeira, orçamentária, operacional e patrimonial, referindo-se às atividades de exame e contraste que objetivam verificar a correção de condutas. Por sua vez, o padrão de correção ao qual a fiscalização haverá de se ater é dado pela citação explícita dos princípios da legalidade, legitimidade e economicidade.

Em relação ao termo "controle", o referido dispositivo constitucional prescreve que a fiscalização será exercida mediante controle interno e externo. O controle interno é aquele que cada Poder exerce sobre si mesmo, e o controle externo será exercido pelo Poder Legislativo, com o auxílio do Tribunal de Contas, sobre os demais Poderes. Desse modo, a atuação fiscalizadora, realizada mediante controle interno e externo, adquire a possibilidade de influenciar e orientar comportamentos próprios ou alheios, abrindo espaço para que os entes controladores possam influir na orientação da atividade financeira do Estado.

Percebe-se que o panorama constitucional exposto não trata a fiscalização e o controle como sinônimos, estabelecendo, entretanto, uma íntima ligação entre eles. A fiscalização é concebida como atividade de averiguação de condutas, já o controle relaciona-se com os entes que detêm a competência para exercer a fiscalização, e, nesse

26 TORRES, Ricardo Lobo. Tratado de Direito Constitucional Financeiro e Tributário: o orçamento na Constituição, v. 5. $3^{\mathrm{a}}$ ed. Rio de Janeiro: Renovar, 2000. p. 461.

${ }^{27}$ MARTINS, Fernando Rodrigues. Controle do Patrimônio Público. São Paulo: RT, 2000. p. 112. 
último caso, os sujeitos controladores acabam por ditar uma orientação e um direcionamento à atividade financeira do Estado. 


\section{DA FISCALIZAÇÃO FINANCEIRA.}

A fiscalização financeira do Estado tem sede constitucional expressa, conforme se depreende da redação do art. 70, caput, da CF de 1988:

"A fiscalização contábil, financeira, orçamentária, operacional e patrimonial da União e das entidades da administração direta e indireta, quanto à legalidade, legitimidade, economicidade, aplicação das subvenções $e$ renúncia de receitas, será exercida pelo Congresso Nacional, mediante controle externo, e pelo sistema de controle interno de cada Poder."

A redação do dispositivo transcrito é complexa, exigindo algum esforço para sua compreensão. Não obstante tal dificuldade, desvendar o sentido e o alcance das expressões utilizadas pelo constituinte é tarefa fundamental para estabelecer a exata noção daquilo que se entende por "fisscalização financeira".

A dicção inicial do art. 70, caput, enuncia: "A fiscalização contábil, financeira, orçamentária, operacional e patrimonial (...)." Nota-se que o texto constitucional refere-se explicitamente à locução "fiscalização financeira", situando-a ao lado de outros tipos ou espécies de fiscalização. Ricardo Lobo Torres ${ }^{28}$, ao comentar esse particular, entende que a Constituição acabou por instituir cinco modalidades distintas de fiscalização. Diz ele que: "Essas modalidades de fiscalização se integram e se implicam mutuamente. A intenção da CF foi, mediante enumeração um tanto pleonástica, não deixar sem controle qualquer tipo de atividade financeira do Estado." 29

$\mathrm{O}$ fato de que essas modalidades se integram e se implicam mutuamente para abarcar toda a atividade financeira do Estado é essencial para a compreensão daquilo que se entende por fiscalização financeira. Sublinhe-se que tais modalidades são descritas de

\footnotetext{
${ }^{28}$ TORRES, Ricardo Lobo. Tratado... p. 461.
}

${ }^{29}$ Idem. 
modo genérico pelo constituinte que, a toda evidencia, não tinha a intenção de estabelecer procedimentos específicos de fiscalização. Note que o constituinte se furta a descrever o iter procedimental de cada modalidade; ele sequer explicita o âmbito de incidência de cada uma delas. É a normativa infraconstitucional e infralegal que individualiza as espécies de fiscalização, precisando a cada uma delas um procedimento específico e um campo de abrangência determinado. ${ }^{30}$

As modalidades de fiscalização previstas na constituição são, na verdade, termos genéricos, ventilados com a preocupação exclusiva de indicar que todo o âmbito da atividade financeira do Estado deve estar sujeito ao controle. Para tanto, é preciso empreender um esforço exegético para apurar, ainda que grosso modo, o objeto afeito a cada modalidade, compondo, assim, a amplitude sobre a qual haverá de recair a fiscalização.

Individualmente, a fiscalização contábil seria aquela que se exerce sobre a escrituração e os registros contábeis efetuados pela Administração Pública. Notadamente, a contabilidade estatal está sujeita ao regime legal imposto pela Lei 4.320 de 1964. O diploma legal indicado disciplina os sistemas e os métodos de escrituração e de registro das contas públicas. Em especial, prescreve o art. 83 que a contabilidade há de evidenciar a situação de todos quantos, de qualquer modo, arrecadem receitas, efetuem despesas, administrem ou guardem bens a ela pertencentes ou confiados. De modo semelhante, o art. 90 dispõe que a contabilidade deverá evidenciar a situação das finanças estatais, indicando os recursos disponíveis, os créditos orçamentários vigentes, a despesa empenhada e realizada, bem como o montante que suportou as despesas.

Destarte, vale ressaltar que sindicância realizada pela fiscalização contábil não se limita a verificar a correção das técnicas de escrituração e se o registro das contas públicas observou as determinações procedimentais. Conforme adverte Aliomar Baleeiro ${ }^{31}$, as malversações com os recursos públicos não podem ser evitadas por qualquer método de

\footnotetext{
${ }^{30}$ Confira, nesse sentido, a Portaria-SEGECEX n ${ }^{\circ}$, de 26 de fevereiro de 2010, e a Portaria-SEGECEX $n^{\circ}$ 26, de 19 de outubro de 2009, ambas do TCU, que estabelecem, respectivamente, dois tipos específicos de auditorias, a operacional e de conformidade. Ou seja, é a normativa infralegal que precisa os procedimentos de fiscalização, instituindo modalidades sindicantes específicas. Por outro lado, as modalidades de fiscalização consignadas nas CF de 1988 não instituem procedimentos específicos e, portanto, não se erigem como tipos autônomos de fiscalização, de modo que não se pode combiná-las com os princípios da legitimidade, economicidade e legalidade. Em outras palavras, não se pode dizer que o constituinte instituiu, especificamente, uma fiscalização patrimonial quanto à economicidade, uma fiscalização orçamentária quanto à legitimidade, etc.

${ }^{31}$ BALEEIRO, Aliomar. Uma introdução à ciência das finanças. Atual. Djalma de Campos. 15. ed. Rio de Janeiro: Forense, 1998. p. 454.
} 
técnica contábil quando são fruto de falsidade ideológica perpetrada pelo gestor público. Logo, a fiscalização contábil deve, também, primar pela apuração da veracidade da escrituração de modo que o sistema de registro evidencie a real situação das finanças estatais. $^{32}$

É de suma importância que a contabilidade revele com clareza e confiabilidade os atos da atividade financeira do Estado, pois a contabilidade é o substrato material, é a fonte na qual se baseiam as outras modalidades de fiscalização. Ricardo Lobo Torres atesta que a fiscalização contábil abrange as demais modalidades de fiscalização, "pois a contabilidade pode ser financeira, orçamentária, operacional e patrimonial." 33 Assim, a eficácia e o êxito das outras modalidades de fiscalização dependem, em larga medida, da regularidade, correção e veracidade dos registros contábeis.

A fiscalização financeira, por sua vez, relaciona-se com o controle da arrecadação de receitas e da realização de despesas. Na síntese lapidar de Régis de Oliveira, a "fiscalização financeira diz respeito ao ingresso e à saída de dinheiro". 34

Sendo assim, quanto aos ingressos, essa modalidade de fiscalização há de ter em conta a regularidade dos meios utilizados para arrecadação, constatando, ainda, se o numerário captado foi convenientemente registrado, uma vez que, a teor do art. 57 da Lei 4.320 de 1964, todas as receitas arrecadadas serão convenientemente classificadas como receitas orçamentárias, sob as rubricas que lhes são próprias.

Já em relação às despesas públicas, a fiscalização financeira visa apurar, principalmente, a higidez do procedimento de execução de despesa, conferindo a existência da autorização legal para o encargo financeiro, verificando, ainda, se as despesas foram devidamente ordenadas, empenhadas, liquidadas, pagas e escrituradas.

De toda sorte, a fiscalização financeira verifica se as despesas efetivadas foram contempladas pelo orçamento público, atrelando-se, em alguma medida, à fiscalização orçamentária. É de se reconhecer, no entanto, que a fiscalização orçamentária ultrapassa a mera verificação das receitas e despesas em face da lei orçamentária.

\footnotetext{
${ }^{32}$ Nesse sentido, Helio Mileski propugna pela "existência de uma contabilidade que espelhe com clareza e confiabilidade os atos da atividade financeira do Estado, mediante um sistema de registros que demonstre a sua real situação econômica e financeira". MILESKI, Helio Saul. O Controle da Gestão Pública, São Paulo: RT, 2003. p. 240.

${ }^{33}$ TORRES, Ricardo Lobo. Tratado ... p. 461.

${ }^{34}$ OLIVEIRA, Régis Fernandes. Curso de Direito Financeiro. $2^{\mathrm{a}}$ ed. São Paulo: RT, 2008, p. 390.
} 
Ocorre que, modernamente, o orçamento não é uma simples peça contábil. Nas lições de Helio Mileski, “o Estado passou a adotar o orçamento-programa, como expressão de um planejamento governamental, em que são fixados um conjunto de metas e objetivos a serem realizados, com identificação dos respectivos recursos financeiros." 35

O regime orçamentário consignado pela CF de 1988 está plasmado nessa perspectiva de planejamento governamental, impondo aos governantes uma adesão compulsória a determinadas metas, planos e objetivos de modo a impedir qualquer atitude descompromissada com o interesse público.

Assim, a fiscalização orçamentária tem por escopo constatar a pertinência da peça orçamentária com os programas, metas e objetivos consignados no planejamento estatal. Em última análise, a "fiscalização orçamentária possibilita que seja verificada a realização dos planos de governo, no sentido de evitar que os recursos financeiros sejam utilizados com desvio de finalidade." 36

Diferentemente da fiscalização orçamentária, que contrasta o orçamento em face dos planos e metas governamentais, a fiscalização operacional preocupa-se em avaliar o grau de cumprimento desses mesmos planos e metas, procedendo a uma análise de eficiência, eficácia e economicidade dos atos de gestão praticados. ${ }^{37}$

Essa modalidade de fiscalização constata se os objetivos e programas fixados nas leis orçamentárias produziram resultados efetivos (eficácia) de modo rápido (eficiência) e ao menor custo possível (economicidade). Nesse particular, a sindicância recai sobre a gestão administrativa, buscando identificar deficiências e apontar as soluções que levam à melhoria da equação custo-benefício.

Sem dúvida, a fiscalização operacional revela uma melhora evolutiva no sistema de controle da atividade financeira do Estado, pois a preocupação não se restringe à preservação dos recursos públicos. Almeja-se, mais ainda, o aprimoramento da atuação

\footnotetext{
${ }^{35}$ MILESKI, Hélio Saul. O Controle... p. 241.

36 Ibid. 242.

${ }^{37}$ Ricardo Lobo Torres afirma que a fiscalização operacional "visa o controle das operações de crédito e de despesas que não constem de previsão orçamentária”. (TORRES, Ricardo Lobo. Tratado ... p. 462). No entanto, na medida em que as operações de crédito importam em ingressos e despesas, é possível alocar tais operações sob o influxo da fiscalização financeira. Desse modo, merece atenção a doutrina de Helio Mileski sobre a fiscalização operacional, que diz: “A fiscalização operacional visa avaliar o grau de cumprimento dos objetivos e metas previstos na lei orçamentária; determinar a eficiência (máximo de rendimento sem desperdício de gastos e tempo), a eficácia (realização das metas programadas) e a economicidade (operação a menor custo possível) dos atos de gestão praticados." (MILESKI, Hélio Saul. O Controle... p. 242).
} 
administrativa, tendo em conta critérios indicativos de produtividade na gestão governamental.

Por fim, alude-se também à fiscalização patrimonial. O conceito de patrimônio público é por demais abrangente, alcançando todos os bens, valores, dinheiros e direitos pertencentes ao Estado. ${ }^{38}$ Essa amplitude conceitual revela a importância da fiscalização patrimonial de modo que nenhuma vantagem econômica do Estado ficará sem a devida sindicância.

Precipuamente, o escopo da fiscalização patrimonial é resguardar o patrimônio público, apurando a correção quanto ao registro, guarda, exploração e conservação dos bens e valores estatais. Quer-se evitar o uso indevido e descurado dos bens públicos, voltando sua gestão, guarda e utilização para a concreta promoção do interesse público.

Ainda em relação à fiscalização patrimonial, cabe informar a posição inovadora de Ricardo Lobo Torres ${ }^{39}$. O autor insere o meio ambiente sob a tutela da fiscalização patrimonial, pois, nesse caso, a titularidade difusa do bem ambiental reclamaria a atuação das Cortes de Contas na fixação do "quantum" devido pelos prejuízos ambientais provocados por culpa ou dolo.

O comento da fiscalização patrimonial encerra a exposição das modalidades de fiscalização, levando à conclusão de que a Constituição previu um extenso rol de modalidades no intuito de não deixar sem controle qualquer âmbito da atividade financeira do Estado. Como se afirmou inicialmente, atentar para o fato de que a fiscalização arquitetada pelo Texto Maior contempla toda atividade financeira do Estado se coloca como ponto fundamental para precisar o sentido da expressão "fiscalização financeira".

Se de um lado, é possível conceber a fiscalização financeira apenas como uma das modalidades de fiscalização a incidir sobre a arrecadação de receitas e realização das despesas, por outro, a fiscalização financeira pode ser apreendida em termos mais globais, sendo aquela fiscalização que se exerce sobre toda a atividade financeira do Estado.

O tema proposto no presente estudo, "a fiscalização financeira quanto à legitimidade", exige que se atribua um significado mais amplo à locução "fisscalização financeira". De início, percebe-se que a apuração da legitimidade não é exclusiva ao exercício de uma das modalidades de fiscalização. A redação do art. 70 não deixa dúvidas

\footnotetext{
${ }^{38} \mathrm{Cf}$. MARTINS, Fernando Rodrigues. Controle do... p. 49 a 62.

${ }^{39}$ TORRES, Ricardo Lobo. Tratado ... p. 462.
} 
de que a fiscalização contábil, a financeira, a orçamentária, a operacional e a patrimonial devem ser contrastadas em face da legitimidade. Em conseqüência, toda a atuação financeira do Estado fica sujeita a um juízo de legitimidade. Assim, é necessário que a "fiscalização financeira" seja compreendida em sentido lato, tendo por objeto toda a atividade financeira do Estado.

Aliomar Baleeiro afirma que a atividade financeira do Estado consiste " $\mathrm{em}$ obter, criar, gerir e despender o dinheiro indispensável às necessidades, cuja satisfação o Estado assumiu". ${ }^{40} \mathrm{O}$ amplo espectro que pode envolver as formas de obtenção, gestão e dispêndio dos recursos públicos aumenta, consideravelmente, o âmbito da fiscalização financeira, superando o simples controle da arrecadação e da realização de despesas previstas no orçamento.

Exemplificativamente, pode-se dizer que a fiscalização financeira concebida em sentido mais alargado envolve, também, a sindicância da exploração, guarda e conservação dos bens patrimoniais do Estado; a verificação dos métodos que permitem estimar receitas futuras; a averiguação das formas de contabilizar os ingressos e os dispêndios; bem como a análise operacional sobre o modo pelo qual as despesas são concretizadas.

Vislumbra-se, desse modo, que a atividade financeira do Estado assume contornos muito amplos, dilatando, em conseqüência, a fiscalização que sobre ela incide. Logo, o estudo aqui proposto não se circunscreve à aferição da legitimidade em relação a uma das modalidades de fiscalização previstas de modo que a fiscalização financeira não se restringe ao controle da arrecadação de receitas e da realização das despesas. Antes, análise da fiscalização financeira quanto à legitimidade terá em conta toda a atividade financeira do Estado, conferindo-se, portanto, um significado mais abrangente ao termo "fiscalização financeira".

\footnotetext{
${ }^{40}$ BALEEIRO, Aliomar. Uma introdução... p. 4.
} 


\section{SISTEMA CONSTITUCIONAL DE FISCALIZAÇÃO FINANCEIRA.}

A fiscalização a que se sujeita a atividade financeira do Estado não se resume às modalidades de fiscalização que a pouco se aludiu. Cumpre destacar que o constituinte arquitetou, nos arts. 70 a 75 da CF de 1988, um amplo e rigoroso sistema de fiscalização das finanças públicas. A amplitude e o rigor que denotam tal sistema constitucional estão, em grande medida, consubstanciados nas disposições emanadas do art. 70, caput. O citado preceito, além de prever as modalidades já mencionadas, dispõe sobre o alcance da fiscalização, os princípios que servem de critério para verificar a correção da gestão financeira, bem como institui duas espécies de controle para processar a atividade fiscalizatória: um controle interno e um externo. Logo, o caput do art. 70 plasma os contornos basilares que dão identidade e feição próprias ao sistema constitucional de fiscalização financeira, razão pela qual esse sistema merece um exame mais detido.

Após enunciar as modalidades de fiscalização, o texto do caput do art. 70 indica que elas recairão sobre a União e sobre as entidades da administração direta e indireta, como se pode notar: "A fiscalização contábil, financeira, orçamentária, operacional e patrimonial da União e das entidades da administração direta e indireta”.

Desse modo, a fiscalização financeira alcança, necessariamente, os órgãos da administração direta e as entidades da administração indireta, representando uma evolução em relação ao ordenamento constitucional pretérito que estendia a fiscalização apenas à União e suas autarquias. ${ }^{41}$

Régis de Oliveira $^{42}$ relata que a hodierna disciplina constitucional põe fim às discussões acerca do controle das entidades paraestatais, nominadamente, as empresas estatais e fundações públicas. Resta claro, portanto, que a natureza privada das empresas públicas e das sociedades de economia mista não se apresenta como óbice ao exercício da fiscalização financeira.

\footnotetext{
${ }^{41} \mathrm{O}$ art. $71, \S 5^{\circ}$, da CF de 1967, que após a EC 1 de 1969 foi reproduzido integralmente no art. 70, § 5º, prescrevia: "As normas de fiscalização financeira e orçamentária estabelecidas nesta seção aplicar-se-ão às autarquias."

42 OLIVEIRA, Régis de. Fiscalização Financeira e Orçamentária. Revista de Direito Público, São Paulo, n. 96, out/dez, 1990, p. 214.
} 
Do mesmo modo, as imprecisões da legislação infraconstitucional e os embates doutrinários que se seguiram sobre a natureza jurídica das fundações não são impedimento para sindicar esse ente da administração. ${ }^{43}$ Nessa esteira, o STF fixou o entendimento segundo o qual as empresas estatais, bem como as fundações instituídas e mantidas pelo poder público, estão sujeitas à fiscalização financeira, submetendo-se à competência do Tribunal de Contas. ${ }^{44}$

Ainda quanto à administração direta deve-se ressaltar o fato de que a fiscalização financeira alcança não só o Poder Executivo, mas também o Poder Legislativo e o Judiciário. Efetivamente, tanto o Judiciário como o Legislativo exercem, muito embora de forma atípica, atos de gestão e dispêndio de recursos públicos, razão pela qual devem ser fiscalizados na forma preconizada pelos arts. 70 e seguintes da Constituição.

Mas a CF de 1988 não se contentou em ampliar o alcance da fiscalização financeira no âmbito da administração pública. A leitura sistemática dos dispositivos constitucionais leva à conclusão de que o alcance da fiscalização supera as fronteiras das entidades estatais, indo alcançar terceiros - pessoas privadas, físicas ou jurídicas - que recebam auxílios, subvenções, ou mesmo guardem, arrecadem e utilizem bens e dinheiros públicos.

É elucidativo desse entendimento o parágrafo único do art. 70 que dispõe:

"Prestará contas qualquer pessoa física ou jurídica, pública ou privada, que utilize, arrecade, guarde, gerencie ou administre dinheiros, bens e valores públicos ou pelos quais a União responda, ou que, em nome desta, assuma obrigações de natureza pecuniária."

\footnotetext{
${ }^{43}$ BANDEIRA DE MELLO, Celso Antônio. Curso de Direito Administrativo. 17 ed. São Paulo: Malheiros, 2004, p. 169 a 172. Segundo Celso Antônio Bandeira de Mello, o Dec. Lei 200 definiu erroneamente as fundações púbicas como entes de direito privado. Para o autor, as fundações têm natureza de direito público, segundo entendimento universal, caracterizando-se, na verdade, como autarquias. Afirma, ainda, que depois do advento da CF de 1988 não resta dúvidas sobre a natureza pública das fundações. Hely Lopes Meirelles aduz, igualmente, que a CF de 1988 transformou as fundações instituídas e mantidas pelo poder público em pessoas de direito público. Cf. MEIRELLES, Hely Lopes. Direito Administrativo Brasileiro. $34^{\mathrm{a}}$ ed. São Paulo: Malheiros, 2008. p. 359 e 360.

${ }^{44}$ BRASIL. Supremo Tribunal Federal. MS 25092/DF. Rel. Min. Carlos Velloso. j. 10.11.2005.
} 
A abrangência do artigo acima citado aponta que o dever de prestação de contas não se dirige apenas aos entes da administração pública, estendendo-se a todos que lidam com o dinheiro público. ${ }^{45}$ Ora, a prestação de contas não tem outra finalidade senão criar condições para o efetivo exercício da fiscalização, pois de nada serviria prestar contas se sobre elas não se realizasse uma atividade de contraste tendente a apreciar a correção de condutas e a regularidade na gestão e aplicação de bens e recursos públicos. Por essa razão é que se pode depreender que o parágrafo único do art.70 induz à fiscalização sobre pessoas que não participam dos quadros da Administração Pública, mas que, por algum motivo, lidam com dinheiros e bens públicos. Nesse sentido, expõe Helio Mileski: ${ }^{46}$

"Tratando-se de um sistema de fiscalização abrangente, evidentemente ele deve alcançar todas as entidades da administração direta e indireta, bem como qualquer pessoa física ou jurídica, pública ou privada, que proceda a ações envolvendo a arrecadação, a guarda, a gerência ou a administração de bens e valores públicos, conforme está expressamente determinado no art. 70 e seu parágrafo único da Constituição."

A possibilidade de sindicar qualquer pessoa que lide com recursos públicos é reforçada pelo teor do caput do art. 70 que determina a fiscalização das subvenções e renúncias de receitas. A menção constitucional expressa desses institutos revela a prudência do constituinte na composição do sistema constitucional de fiscalização financeira, uma vez que tanto as subvenções como as renúncias de receitas importam na disposição de recursos públicos em benefício de terceiros que podem não integrar a estrutura administrativa do Estado.

A concessão de subvenções, regulada pelos arts. 16 a 19 da Lei 4.320 de 1964, destina-se ao financiamento de despesas de custeio de pessoas públicas ou privadas. Mais precisamente, como afirma Régis de Oliveira $^{47}$, as subvenções são auxílios financeiros

\footnotetext{
${ }^{45}$ Régis de Oliveira sintetiza o que foi exposto na seguinte frase: "Está obrigado à prestação de contas toda e qualquer pessoa que lide com recursos públicos.” OLIVEIRA, Régis Fernandes. Curso ..., p. 393.

${ }^{46}$ MILESKI, Hélio Saul. O Controle... p. 244.

${ }^{47}$ OLIVEIRA, Régis Fernandes. Curso... p. 380.
} 
consignados no orçamento para o custeio de entidades públicas ou particulares que desenvolvem atividades assistenciais, culturais e empresariais.

Nota-se que as subvenções, por constarem explicitamente do orçamento, consubstanciam-se como despesas públicas. Esse fato é evidenciado pela classificação constante do art. 12 da Lei 4.320 de 1964 que coloca tais auxílios sob a categoria de despesa corrente.

Porém, se resta claro que as subvenções configuram-se em despesa para o Estado, o mesmo não se pode afirmar das renúncias de receitas. Por óbvio, as renúncias de receitas afetam a arrecadação, no entanto, não constam como despesas ou gastos previstos na lei orçamentária. Tal fato poderia gerar alguma dificuldade quanto à fiscalização dos mecanismos que levam à perda de arrecadação. Elcio Fiori ${ }^{48}$, em obra sobre os benefícios fiscais, dá conta que os americanos acabaram por cunhar a expressão tax expedinture (gasto tributário), relacionando as renúncias de receitas às despesas públicas no intuito de proporcionar um controle mais profundo sobre a diminuição da arrecadação provocada pelos benefícios fiscais.

No caso brasileiro, com a previsão constitucional da sindicância das renúncias de receitas fica indubitável a possibilidade de se apurar qualquer mecanismo que leve a perda ou diminuição de receitas públicas. Louve-se, ainda, o emprego da expressão "renúncia de receitas" pelo Texto Maior. A abrangência dessa expressão indica que não só os benefícios fiscais próprios do direito tributário devem se submeter à fiscalização, mas também, conforme anota Ricardo Lobo Torres, “quaisquer outros favores mascarados ou camuflados, que impliquem em redução de receita e que não se escriturem como 'itens de da despesa pública'., 49

Diante da larga extensão da fiscalização financeira, cabe confirmar a prudência e o rigor que pautaram o trabalho do constituinte. Além de alcançar a administração direta e indireta, bem como qualquer pessoa que lide com recursos públicos, a fiscalização, tal como plasmada na Constituição, faz questão de reforçar que tanto as subvenções como as renúncias de receitas estão sujeitas àquela sindicância que se exerce sobre a atividade financeira do Estado.

${ }^{48}$ Cf. HENRIQUES, Elcio Fiori. Os Benefícios Fiscais no Direito Financeiro e Orçamentário: o gasto tributário no direito brasileiro. São Paulo: Quartier Latin, 2010. p. 46 a 51.

${ }^{49}$ TORRES, Ricardo Lobo. Tratado ... p. 465. 
Mas de nada adiantaria tecer comentários sobre as modalidades de fiscalização e seu alcance, se a fiscalização da atividade financeira do Estado se limitasse a uma análise puramente técnica e procedimental. Ressalte-se, nesse contexto, a existência de princípios voltados à fiscalização das contas públicas, pois prescreve o caput do art. 70 que as modalidades de fiscalização haverão de considerar os princípios da legalidade, legitimidade e economicidade.

Logo, a fiscalização não se resume a uma tarefa de mera averiguação e constatação quanto à correção do procedimento empregado. A fiscalização, sobretudo, há de constatar a observância de determinados princípios, por meio dos quais será possível estabelecer uma avaliação jurídica e material do ato sindicado. Aduz Helio Mileski que "um ato de despesa pode ter seu registro contábil regular, mas por ser uma despesa ilegal ou ilegítima, deve ser impugnado mediante uma avaliação jurídico-legal, consoante o sistema normativo nacional." 50 Portanto, toda atividade fiscalizatória levará em consideração a análise dos princípios consignados no art. 70, através dos quais se franqueia a apuração da validade jurídica dos atos relativos à guarda, gestão e dispêndio de recursos públicos.

É interessante notar que Mauricio $\operatorname{Conti}^{51}$ ao estudar o tema denomina a legalidade, economicidade e legitimidade como aspectos da fiscalização. Para este autor, a fiscalização é entendida como uma atividade de contraste cujo objetivo é verificar a adequação das condutas. Assim, a legalidade, a economicidade a legitimidade seriam aspectos a serem constatados na atividade financeira do Estado, sem os quais não seria possível concluir pela correção de condutas.

Já Helio Mileski ${ }^{52}$ entende a legalidade, economicidade e legitimidade como princípios. Segundo ele, a efetividade da fiscalização das finanças públicas é fator fundamental na composição do Estado de Direito, pois impede que a atuação estatal se desvie do interesse público. $\mathrm{O}$ autor observa que um sistema de fiscalização despreocupado com valores fundamentais não seria efetivo, minando as bases do Estado de Direito.

Colacionar esses dois entendimentos sobre o papel da legalidade, economicidade e legitimidade na fiscalização é de extrema importância. $\mathrm{Na}$ verdade, a posição ventilada pelos dois autores não são excludentes, antes se complementam. Não se

\footnotetext{
${ }^{50}$ MILESKI, Hélio Saul. O Controle... p. 239.

${ }^{51}$ CONTI, José Maurício. Direito Financeiro na Constituição de 1988. São Paulo: Oliveira Mendes, 1998, p. 4.

${ }_{52}$ MILESKI, Hélio Saul, O Controle... p. 246.
} 
pode deixar de reconhecer que a fiscalização é uma atividade de contraste que objetiva averiguar a correção de condutas, sendo que a legalidade, a economicidade e a legitimidade são aspectos com os quais a atividade financeira do Estado deve se conformar. Por outro lado, é inegável que tais aspectos expressam valores fundamentais na construção do Estado de Direito, razão pela qual podem se alçar à categoria de princípios.

Nas lições de Canotilho, os princípios expressam um forte conteúdo axiológico, consubstanciando-se em standards radicados na exigência de justiça. ${ }^{53}$ No particular da fiscalização financeira, o mesmo se pode dizer da legalidade, da legitimidade e da economicidade, pois são preceitos valorativos genéricos que impedem desvios na condução das finanças públicas, garantido que a atuação dos gestores da "res" pública não se afaste dos ditames do interesse público.

É emblemático, por exemplo, o princípio da legalidade. Se existe um princípio ao qual a administração pública se submete de maneira incontestável, esse princípio é o da legalidade. Acerca desse princípio cunhou-se a célebre formulação doutrinária: “Enquanto na administração particular é lícito fazer tudo o que a lei não proíbe, na administração pública só é permitido fazer aquilo que a lei autoriza. " 54

No tocante à fiscalização financeira, o princípio da legalidade inscrito no art. 70 da Constituição assume vetores próprios. De fato, em uma afirmação despretensiosa pode-se dizer que a fiscalização quanto à legalidade busca verificar se a atividade financeira está de acordo com a lei. Mas é imperioso constatar que essa sujeição à lei comporta dois desdobramentos.

O primeiro desdobramento se relaciona com o fato de que todas as receitas e despesas públicas deverão ser expressas por lei. A Constituição exige que as despesas e receitas sejam veiculadas por lei orçamentária, estabelecendo, na verdade, uma reserva de lei. Precisamente, conforme esclarece José Afonso da Silva ${ }^{55}$, a reserva de lei não se confunde com a legalidade; esta significa submissão e respeito à lei, já aquela se dá quando a norma constitucional atribui à lei o tratamento de determinada matéria. Percebe-se, diante de tal fato, que a reserva de lei atrela-se, necessariamente, ao esquema de separação dos poderes, reclamando a participação do Legislativo para autorizar as despesas dos demais Poderes.

\footnotetext{
${ }^{53}$ CANOTILHO, José Joaquim Gomes. Direito Constitucional. $5^{\mathrm{a}}$ ed. Coimbra: Almedina, 1992. p. 1034 e 1035.

${ }^{54}$ MEIRELLES, Hely Lopes, Direito Administrativo ... p. 89.

${ }^{55}$ SILVA, José Afonso. Curso ... p.421.
} 
Por outro lado, o princípio da legalidade inscrito no art. 70, caput, também exige submissão à lei. Há, portanto, um segundo desdobramento. Não basta constatar que as receitas e as despesas devem ser previstas em lei, é preciso, também, acalentar a idéia de submissão à lei orçamentária, de modo que os gastos públicos só poderão ser efetivados se estiverem autorizados pela citada lei. Não se admite, portanto, a realização de despesas ou assunção de obrigações que não estejam previstas ou que excedam às dotações consignadas na lei orçamentária. ${ }^{56}$

É claro, no entanto, que a necessidade de submissão à lei não se restringe à observância das leis orçamentárias. A submissão à lei apregoada pelo princípio da legalidade tende a verificar se a atuação financeira do Estado está em conformidade com todo o ordenamento jurídico. Advoga, nesse sentido, a doutrina de Mauricio Conti, afirmando que a legalidade inscrita no artigo 70 da Constituição, "não deve ser compreendida na sua concepção mais restrita, como uma das espécies de norma jurídica, mas em seu sentido amplo, de forma a abranger também as normas hierarquicamente superiores e inferiores." 57

No entanto, um sistema de fiscalização que tivesse por critério de correção de condutas unicamente a legalidade formal, seria um sistema deficiente. Há muito tempo já proclamavam os jurisconsultos romanos que Non omne quod licet honestum est. Em vernáculo: nem tudo o que é lícito, é honesto.

Nesse diapasão, o constiuinte de 1988 determinou que o princípio da legitimidade também fosse considerado quando da fiscalização das finanças públicas. A previsão desse princípio permite uma fiscalização mais substancial e profunda sobre a atividade financeira do Estado, na medida em que a lei formal não é padrão único de correção das condutas.

Não é incomum verificar a existência de atos de disposição financeira hígidos, sob a ótica da legalidade formal, mas que não se preocupam com a realização do interesse público, desprezando os mais elementares fundamentos éticos do ordenamento. Assim, a sindicância da legitimidade possibilita enfrentar questões formalmente hígidas, mas materialmente equivocadas.

\footnotetext{
56 Nesses termos, prescreve o art. 167, II, da CF de 1988: "São vedadas a realização de despesas ou a assunção de obrigações diretas que excedam os créditos orçamentários ou adicionais."

${ }^{57}$ CONTI, José Maurício. Direito Financeiro... p. 4.
} 
Superar o mero aspecto da legalidade formal é imprescindível para que a fiscalização possa ser efetiva. Nesse sentido, a correção material do ato sindicado não é conferida unicamente pela observância do princípio da legitmidade. É de se notar que a Constituição fez alusão expressa ao princípio da economicidade. Não basta constranger o Estado a observar disposições éticas que ultrapassam a mera legalidade formal, é preciso que sua atuação seja adequada e eficiente, utilizando os recursos disponíveis da melhor maneira possível.

O princípio da economicidade revela, em uma primeira compreensão, a idéia de contrariedade a qualquer tipo de gastos exagerados, desperdícios e prodigalidade com os recursos financeiros. Conforme essa noção preliminar, exige-se que a gestão dos recursos públicos seja comedida, pois a persecução do interesse público não admite qualquer desperdício com os recursos do erário.

Mas, diante de infindáveis necessidades dos cidadãos em contraste com o conteúdo limitado dos cofres públicos, figura-se como imperativo lógico que os recursos sejam usados da melhor maneira possível, buscando sempre uma equação ótima em que se consideram as variáveis "custo" e "benefício".

Note bem que a fiscalização quanto a esse princípio não faz pressupor que a correção da conduta administrativa seja alcançada quando se gasta o menos possível. A gestão financeira está atrelada às necessidades públicas, logo, a economicidade não deve se confundir com limitação e contenção de gastos. A administração não pode se furtar a atender às necessidades a que está obrigada a satisfazer, sob o pretexto de resguardar o erário. Destarte, a economicidade revela-se quando a administração satisfaz as necessidades públicas com a menor soma possível.

Desse modo, a fiscalização da economicidade verificará, ao final, se a conduta da Administração obteve êxito na equação custo-benefício. Ou seja, se ela conseguiu o melhor benefício desejável ao menor custo possível. Busca-se a otimização nos gastos públicos, havendo, em última análise, uma fiscalização quanto à eficiência da administração.

O princípio da economicidade relaciona-se intimamente com o princípio da eficiência, os quais, muitas vezes, confundem-se, valendo notar que o conteúdo por eles expresso propõe uma excelência na aplicação dos recursos públicos. Nesse sentido, alude Márcia Mata: 
"economicidade traduz antes de tudo um compromisso econômico com o cumprimento de metas governamentais, inseridas na equação custo e benefício, onde a eficiência e a eficácia estão introduzidas como finalidade última de toda e qualquer receita destinada a um interesse público". 58

Assim sendo, a verificação da economicidade constatará se a administração está empregando os recursos públicos com racionalidade e equilíbrio, de acordo com a equação custo-benefício, que denota, em última análise, a eficiência da administração.

Da exposição dos princípios afeitos à fiscalização financeira, nota-se que a economicidade, a legitimidade e a legalidade apresentam um conteúdo prescritivo próprio das normas principiológicas, pois, em vez de prescrever um comportamento determinado, tais preceitos consubstanciam-se em standards de observância compulsória cujo escopo é garantir a regularidade na condução da atividade financeira do Estado.

Ponto fundamental, nesse sentido, é ressaltar aos princípios em comento a característica de mandados de otimização. Conforme a clássica lição de Alexy, os princípios não são aplicáveis sob a perspectiva do "tudo ou nada", o que vale dizer que "os princípios são normas que ordenam que algo seja realizado na maior medida possível dentro das possibilidades jurídicas e fáticas existentes."

Ocorre que, não raro, os princípios citados podem colidir uns com os outros: a necessidade de buscar uma atuação legítima, por exemplo, pode confrontar-se com o dever de economicidade. Ou, então, a adstrição à legalidade pode figurar-se como óbice à implementação mais efetiva da justiça, minando a consecução da legitimidade na atuação financeira. Nesses casos de colidência entre princípios, a doutrina de Alexy mostra-se muito profícua.

Ao conceber os princípios como mandados de otimização, o autor condiciona a aplicabilidade de determinado princípio às condições fáticas e jurídicas presentes no caso. $^{60}$ Assim, constatado o confronto entre normas de natureza

\footnotetext{
${ }^{58}$ FILOMENA, Márcia Mata. Fiscalização da Administração Pública em face da economicidade. RT, São Paulo, n.710, dez. 2004. p. 236.

${ }^{59}$ ALEXY, Robert. Teoria dos Direitos Fundamentais. Trad. Virgílio Afonso da Silva. São Paulo: Malheiros, 2008. p. 90.

${ }^{60}$ Segundo Virgílio Afonso da Silva: "A principal contribuição de Alexy à teoria forte sobre a distinção entre princípios e regras foi o desenvolvimento do conceito de mandado de otimização." Nesses termos,
} 
principiológica, um princípio acaba prevalecendo sobre o outro sempre que as condições presentes no caso assim indicarem. ${ }^{61}$ Em última análise, é uma ponderação de razoabilidade e proporcionalidade que orienta a precedência de um princípio sobre outro. Nas lições de Alexy:

“Afirmar que a natureza dos princípios implica a máxima da proporcionalidade significa que a proporcionalidade, com suas três máximas parciais da adequação, da necessidade (mandamento do meio menos gravoso) e da proporcionalidade em sentido estrito, decorre logicamente da natureza dos princípios, ou seja, que a proporcionalidade é deduzível dessa natureza."62

Existindo, então, uma colisão entre princípios não se pode presumir que a aplicação de um importa na anulação completa do outro. Diante da situação concreta, busca-se a norma principiológica mais adequada ao caso (adequação) por meio da ponderação dos dois comandos normativos (proporcionalidade em sentido estrito), na qual o princípio prevalente representa sempre a escolha menos gravosa de modo a não excluir, totalmente, o princípio prejudicado (necessidade).

De toda sorte, essa exposição sobre a colidência e a ponderação entre os princípios faz-se necessária para reforçar o caráter principiológico dos preceitos da legalidade, legitimidade e economicidade consignados no caput do art. 70. Paulo Soares de Bugarin $^{63}$ não deixa de notar que um dos órgãos responsáveis pela aferição desses princípios, o Tribunal de Contas, depara-se muitas vezes com situações nas quais tais comandos normativos se apresentam em confronto. Em tal contexto, vislumbra o autor que a Corte de Contas procede a um juízo de ponderação para desvendar qual princípio deve ser aplicado.

revela o próprio Virgílio, o grau de realização dos princípios pode variar, especialmente diante da existência de um princípio que imponha um direito ou um dever que colida com outros princípios existentes. SILVA, Virgílio Afonso da. A constitucionalização do Direito: os direitos fundamentais nas relações entre particulares. São Paulo: Malheiros, 2008. p. 32.

${ }_{61}^{61}$ ALEXY, Robert. Teoria... p. 93 e 94.

${ }^{62}$ Ibid. p. 116 e 117.

${ }^{63}$ BUGARIN, Paulo Soares. O Princípio da Economicidade na Jurisprudência do Tribunal de Contas da União. Belo Horizonte: Editora Fórum, 2004. p.188 a 190. 
Baseado em precedente do Tribunal de Contas no qual se admitiu, em vista da economicidade, o aditamento contratual sem nova licitação, Bugarin afirma que "se verificou que o cumprimento do princípio da economicidade resultou na violação do princípio da legalidade, tendo sido, na oportunidade, conferido maior peso ao primeiro."64

Desse modo, a aferição da legitimidade, da economicidade e da legalidade previstas no art. 70 não se dá, eventualmente, sem alguma dificuldade, sendo esta, todavia, superada pelos mecanismos que permitem dirimir a colisão entre princípios. Outrossim, é preciso reconhecer que estes mandados de otimização afeitos ao controle de contas representam, tão somente, uma parte do sistema de fiscalização preconizado na CF de 1988.

Como já se afirmou, o constituinte arquitetou um complexo sistema de fiscalização financeira, que além de dispor sobre as modalidades, o alcance e os princípios norteadores da fiscalização, estabelece, também, quem são os responsáveis por exercer a atividade fiscalizatória. Nesse sentido, o art. 70, caput, da CF, aduz que a fiscalização financeira "será exercida pelo Congresso Nacional, mediante controle externo, e pelo sistema de controle interno de cada Poder."

Percebe-se que a discriminação constitucional entre controle externo e interno toma como fator diferencial um elemento subjetivo, pois o traço que define as duas formas de controle reside no ente que exercerá a fiscalização. Mediante controle externo, a fiscalização será exercida pelo Congresso Nacional. O controle interno, de seu turno, realiza-se através da fiscalização que cada Poder realiza sobre si mesmo.

Assevera Helio Mileski ${ }^{65}$ que "o sistema de fiscalização está assentado na dualidade de controle", pois a sindicância se processa tanto pelo controle interno, como através do controle externo. José Afonso da Silva distingue, nessa linha, entre dois "sistemas de controle financeiro-orçamentário". De fato, a divisão operada pelo citado constitucionalista baseia-se em um critério orgânico, no entanto, esta distinção está vinculada às diferentes maneiras pelos quais o controle é exercido. Segundo ele, " $a$ perspectiva para a diferenciação em sistemas de controle é orgânica e, em função desta, os diferentes modos de seu exercício." 66

\footnotetext{
${ }^{64}$ Ibid. p. 188.

${ }^{65}$ MILESKI, Hélio Saul, O Controle... p. 157.

${ }^{66}$ SILVA, José Afonso. Curso... p. 731.
} 
É preciso dizer que, embora as modalidades, o alcance e os princípios explicitados no art. 70, caput, da CF sejam comuns a ambos os tipos de controle, a própria Constituição estabelece modos distintos de se exercer a fiscalização, conforme se trate do controle interno ou externo. ${ }^{67}$ Nota-se que o constituinte fixou um regime constitucional específico para cada uma duas formas de controle; assim, a fiscalização mediante controle interno opera-se de modo substancialmente diverso da fiscalização mediante controle externo.

Destarte, a distinção quanto ao exercício da fiscalização financeira pelas duas formas de controle reclama um exame mais detido com vistas a expor o regime constitucional afeito a cada um deles.

${ }^{67}$ Segundo Ricardo Lobo Torres: "O controle interno é simétrico ao externo no que pertine às finalidades, objeto e métodos." TORRES, Ricardo Lobo. Tratado... p. 480. 


\section{CONTROLE EXTERNO E INTERNO.}

O constituinte de 1988 elaborou um amplo sistema de fiscalização da atividade financeira do Estado regulando as modalidades de fiscalização e o alcance delas, sem deixar de consignar princípios que servem de parâmetro para evidenciar a correção da gestão financeira do Estado. Ocorre, porém, que esse sistema está fundado na dualidade de controle. A CF de 1988 preceitua que a fiscalização será executada pelo Congresso Nacional, mediante controle externo, e pelo sistema de controle interno de cada Poder.

$\mathrm{Na}$ verdade, essa dualidade de controle acarreta uma distinção substancial entre a fiscalização exercida mediante o controle interno e o controle externo. Ora, a distinção orgânica como elemento que define os tipos de controle, corresponde, também, a uma disparidade de funções, razão pela qual o modo como se conduz a fiscalização pelo controle interno não pode ser o mesmo do controle externo.

Celso Bastos $^{68}$ reconhece que a principal contribuição da teoria de separação de poderes concebida por Montesquieu é o fato de que aos distintos Poderes do Estado correspondem funções específicas, pois “à divisão funcional deve corresponder uma divisão orgânica."

Assim, o desenho institucional da divisão de poderes arquitetado pela Constituição atribuiu ao Congresso Nacional um peculiar mecanismo de fiscalização financeira, uma vez que tal fiscalização é exercida pelo Legislativo sobre os demais Poderes, inserindo-se na composição do equilíbrio e da harmonia necessários à efetivação da teoria de Montesquieu. O controle externo, portanto, assume um papel fundamental na elaboração do consagrado sistema dos "checks and balances" pelo qual, o controle de um Poder sobre o outro, longe de ser uma ingerência indevida, representa uma forma de contenção do poder pelo próprio poder. ${ }^{69}$

\footnotetext{
${ }^{68} \mathrm{O}$ autor afirma que: "O mérito essencial da teoria de Montesquieu não reside na identificação abstrata dessas formas de atuar do Estado. Isto, como já vimos, fora feito, se bem que mais toscamente, na Antigüidade, por Aristóteles. Montesquieu, entretanto, foi aquele que primeiro, de forma translúcida, afirmou que 'a tais funções devem corresponder órgãos distintos e autônomos'." BASTOS, Celso Ribeiro. Curso de Direito Constitucional. São Paulo:Celso Bastos Editora, 2002. p. 560 e 561.

${ }^{69}$ Manoel Gonçalves leciona, nesse sentido, aduzindo que: "Montesquieu via na separação de poderes uma doutrina política, um meio de o poder deter o poder". (FERREIRA FILHO, Manoel Gonçalves. Princípios... p. 257.) Igualmente Celso Basto aduz que: "Montesquieu concebia sua teoria da separação de poderes como 'técnica' posta a serviço da contenção do poder pelo próprio poder.” (BASTOS, Celso Ribeiro. Curso ... p. 561.).
} 
O controle interno, de seu turno, é aquele exercido por cada Poder sobre si mesmo. Na doutrina de Julio Cesar de Araujo: “O controle interno caracteriza-se por ser um controle que se desenvolve dentro do ambiente doméstico, levando-se em conta a identidade de situação orgânica entre o órgão que emite o ato passível de controle e o órgão controlador." 70

Destarte, a fiscalização realizada mediante controle interno não leva ao controle de um Poder sobre o outro, mas a fiscalização remanesce no âmbito do próprio ente controlador. Apesar disso, a Constituição Federal é contundente ao afirmar que uma das finalidades do controle interno é apoiar a missão institucional do controle externo. Desse modo, embora distintos, o controle externo e interno estão, em alguma medida, relacionados, podendo-se afirmar que as duas formas de controle contribuem para limitar e equilibrar o exercício do poder.

Interessa, contudo, analisar os regimes constitucionais afeitos a cada tipo de controle no intuito de verificar como se processa a fiscalização financeira mediante controle externo e interno.

\section{$5.1 \mathrm{O}$ controle interno.}

O controle interno é uma atividade corrente na administração pública. Odete Medauar $^{71}$ atesta que o controle interno confunde-se com o chamado "controle na administração", ou seja, é aquele tipo de controle exercido pela própria Administração sobre suas estruturas.

Hely Lopes Meirelles ressalta, por sua vez, a abrangência do controle interno, esclarecendo que ele não se concentra, tão somente, nas estruturas do Poder Executivo. Diz ele:

"qualquer controle efetivado pelo Executivo sobre seus serviços e agentes é considerado 'interno', como 'interno'

\footnotetext{
${ }^{70}$ ARAUJO, Julio Cesar Manhães de. Controle da atividade administrativa pelo Tribunal de Constas na Constituição de 1988. Curitiba: Juruá Editora, 2010. p. 68.

${ }^{71}$ MEDAUAR, Odete. Controle... p.37.
} 
será também o controle do Legislativo ou do Judiciário, por seus órgãos de administração, sobre o seu pessoal e atos administrativos que pratique." 72

O autor destaca que controle interno aplica-se no âmbito de todos os Poderes, uma vez que, de modo típico ou atípico, todos realizam a atividade administrativa. A administração pública, assim, não é função exclusiva do Poder Executivo, estendendo-se, aos demais Poderes e, por conseguinte, o controle interno administrativo é exercido no âmbito de todos eles.

Ainda, pode-se aduzir que esse controle interna corporis é genérico ou específico. Ele será genérico quando no campo de sua definição couber variadas formas de controle interno. Por exemplo, fala-se em controle interno quando a Administração exerce o chamado controle hierárquico, como nos casos em que o ordenamento dota o órgão administrativo superior com competência para rever, através de recurso administrativo, as decisões proferidas pelos órgãos inferiores. Também, ingressa no âmbito do controle interno o chamado autocontrole, decorrente da prerrogativa de autotutela, pela qual a autoridade administrativa pode revogar ou anular determinado ato administrativo.

De outro modo, há particularidades sobre as quais o controle interno se debruça, formatando, então, um controle interno específico. Logo, dentre as variadas formas de controle interno, há um controle especificamente financeiro. Odete Medauar, amparada nas lições de Puget, assevera que: “os controles internos são gerais ou especiais, estes últimos incidindo sobre aspectos particulares da atuação administrativa, como é o caso do controle financeiro." 73 Helio Mileski, reconhece, na mesma linha, a particularidade do controle interno financeiro, pois, segundo ele: "no que diz respeito à fiscalização contábil, financeira e orçamentária, este tipo de controle - o interno - assume uma especificidade mais definida." 74

Frise-se que a CF de 1988 só menciona o termo "controle interno" quando trata da fiscalização financeira do Estado. A referência do constituinte ao controle interno encontra-se no final da redação do art. 70, caput, onde se lê que a fiscalização será exercida "pelo sistema de controle interno de cada Poder." A dicção constitucional indica a

\footnotetext{
${ }^{72}$ MEIRELLES, Hely Lopes. Direito... p. 674.

${ }^{73}$ MEDAUAR, Odete. Controle... p.42.

${ }^{74}$ MILESKI, Hélio Saul. O Controle... p. 157.
} 
necessidade do controle interno se erigir como um sistema. Para tanto, os Poderes devem criar órgãos próprios com atribuições para fiscalizar o interior de suas respectivas estruturas administrativas. ${ }^{75}$

A criação de órgãos dotados de estrutura própria e pessoal adequado para exercer a fiscalização mediante controle interno é, portanto, um imperativo constitucional. Leciona Mauricio Conti: "Toda a Administração Pública, incluindo não só o Poder Executivo, como também o Legislativo e o Judiciário, devem manter órgãos destinados a realizar esse tipo de fiscalização." 76

De outra parte, constata-se que o órgão de controle externo fiscaliza a implantação e a correção dos órgãos de controle interno. Nesse sentido, o TCU tem verificado a qualificação e capacidade técnica dos agentes que compõem o órgão de controle interna corporis, bem como se tais órgãos possuem autonomia e estrutura condizentes para a efetivação da fiscalização. ${ }^{77}$

Mas o fato de que o controle interno financeiro se consubstancia em órgãos com estrutura e pessoal adequado é fator que o distingue das outras formas de controle na administração. Nota-se certa confusão conceitual entre o que seja o controle interno financeiro, poder hierárquico e autotutela, no entanto, tais figuras restam distinguíveis. Essa afirmação encontra eco nas lições de Mauricio Conti que atesta: “ $O$ controle interno não se confunde com o autocontrole nem com o poder hierárquico." 78

Ora, o poder hierárquico é a verificação de correção que os órgãos superiores realizam sobre os inferiores, podendo, nesse diapasão, rever e alterar os atos praticados pelos subordinados, delegar e avocar competências, punir, etc. ${ }^{79}$ Já a autotutela é a fiscalização que a autoridade administrativa exerce sobre os atos que expede, podendo revogá-los ou anulá-los. A autotutela possui reconhecimento sumulado no STF.

\footnotetext{
${ }^{75}$ Jorge Ulisses Fernandes aponta que o controle interno "associa-se à noção de estrutura própria (recursos humanos e materiais), de um sistema." FERNANDES, Jorge Ulisses Jacoby. Tribunais de Constas do Brasil: jurisdição e competência. Belo Horizonte: Fórum, 2003. p. 54.

${ }_{77}^{76}$ CONTI, José Maurício. Direito Financeiro... p. 55.

${ }^{77}$ Sobre a necessidade de implantação de órgãos responsáveis pelo controle interno, infelizmente, é preciso constatar que muitos municípios brasileiros ainda não possuem estruturas próprias para realização do controle, em consequiência, os TCEs tem expedido atos normativos no sentido de obrigar a implantação de órgãos de controle interno. Nesse sentido, confira as resoluções $n^{\circ}$ 7.739/2005 do TCM/PA e 1120/05 do TCM-BA. Sobre dotar os órgãos de controle interno com estrutura e pessoal técnico adequado confira: BRASIL. Tribunal de Contas da União. TC - 009.569/2005-3. Rel. Min. Benjamin Zymler. j. 20.09.2005 e BRASIL. Tribunal de Contas da União. TC - 012.060/2004-4. Rel. Min. Benjamin Zymler. j. 25.07.2005.

${ }_{79}^{78}$ CONTI, José Maurício. Direito Financeiro... p. 55.

${ }^{79}$ Cf. DI PIETRO, Maria Sylvia Zanella. Direito Administrativo. 22a ed. São Paulo:Atlas, 2009. p. 70.
} 
Especificamente, as Súmulas 346 e 437 chancelam à Administração a prerrogativa de sindicar os atos que emite. ${ }^{80}$

Desse modo, embora o poder hierárquico e a autotutela representem formas de controle interno da Administração, eles não se confundem com o controle interno prefigurado no íntimo da fiscalização financeira. Este se materializa em órgãos próprios, sendo que sua matriz constitucional explícita determina a integração desses órgãos em um sistema, arrolando-lhes, também, finalidades definidas.

Assim dispõe o art. 74 da Constituição Federal:

“Art. 74. Os Poderes Legislativo, Executivo e Judiciário manterão, de forma integrada, sistema de controle interno com a finalidade de: I - avaliar o cumprimento das metas previstas no plano plurianual, a execução dos programas de governo e dos orçamentos da União; II - comprovar a legalidade e avaliar os resultados, quanto à eficácia e eficiência, da gestão orçamentária, financeira e patrimonial nos órgãos e entidades da administração federal, bem como da aplicação de recursos públicos por entidades de direito privado; III - exercer o controle das operações de crédito, avais e garantias, bem como dos direitos e haveres da União; $I V$ - apoiar o controle externo no exercício de sua missão institucional. $\S 1^{o}$ - Os responsáveis pelo controle interno, ao tomarem conhecimento de qualquer irregularidade ou ilegalidade, dela darão ciência ao Tribunal de Contas da União, sob pena de responsabilidade solidária."

O dispositivo constitucional citado impõe que os Poderes Legislativo, Executivo e Judiciário mantenham um sistema integrado de controle interno. Nos termos da CF de 1988, os órgãos de controle de cada Poder devem compartilhar um sistema

\footnotetext{
${ }^{80}$ Súmula 346/STF: “A Administração pode declarar a nulidade de seus próprios atos.” Súmula 473/STF: “A administração pode anular seus próprios atos quando eivados de vícios que os tornem ilegais, porque deles não se originam direitos; ou revogá-los, por motivo de conveniência ou oportunidade, respeitados os direitos adquiridos ressalvada, em todos casos, a apreciação judicial."
} 
conjunto, no qual "a parte depende do todo e o todo depende da parte, pois cada unidade sistêmica deve atuar com regularidade para não causar prejuízos à outra, ou, via de conseqüencia ao todo." 81

Nessa linha, o Manual de Controlo/Controle Interno elaborado pela OECI$\mathrm{CPLP}^{82}$, indica que a cooperação sistêmica das unidades de controle evita a sobreposição de ações fiscalizadoras e proporciona o reconhecimento de espaços não controlados, conferindo, assim, maior racionalidade à sindicância interna. ${ }^{83}$ Pode-se adicionar, também, que a atuação sistêmica e integrada dos órgãos de controle contribui para uniformizar os procedimentos fiscalizatórios, compartilhando informações e diminuindo esforços no intuito de aumentar a eficiência sindicante.

Almejar a eficiência e a racionalidade com a instituição de um controle interno sistêmico não possui outra finalidade senão garantir boas práticas administrativas. ${ }^{84} \mathrm{Em}$ menor ou maior medida todos os Poderes realizam atividades administrativas que importam em dispêndio de recursos públicos. A gestão desse numerário deve se pautar pela excelência administrativa e apontam, nessa direção, as finalidades constitucionais arroladas ao controle interno.

Os incisos I e II do art. 74 prescrevem que o controle interno não se presta somente a verificar a legalidade na gestão dos recursos. Essa forma de controle deve, primordialmente, exercer uma verificação de eficiência e eficácia da conduta administrativa, avaliando, para tanto, o cumprimento de metas e resultados dos planos de governo.

Como já se fez notar, a atuação financeira do Estado está fundada sob a perspectiva do planejamento, nesse compasso, o controle interno há de fiscalizar a adstrição dos Poderes aos planos e metas traçados pela programação administrativa. Além disso, ao sistema de controle interno cabe apurar a eficiência e a eficácia dos planos e

\footnotetext{
${ }^{81}$ MILESKI, Helio Saul. O Controle... p. 159 e 160.

82 ORGANISMOS ESTRATÉGICOS DE CONTROLO/CONTROLE INTERNO-COMUNIDADE DE PAÍSES DE LÍNGUA PORTUGUESA.

83 Manual de Controlo/Controle Interno. p. $8 \quad e \quad 9 . \quad$ Disponível em: http://www.cgu.gov.br/eventos/SFC2009_CPLP/Arquivos/ManualControle.pdf. Acesso 28.04.2011.

${ }^{84}$ Nesse sentido: "A noção de um sistema de controle na Administração Pública, portanto, deve ser exaltada, uma vez que o que se busca é a conformação da conduta do agente com regras predeterminadas de gestão razoável e eficiente da coisa pública." CASTRO, Rodrigo Pironti Aguirre de. Sistema de Controle Interno. Disponível em: http://www.tce.to.gov.br/seminarioLRF/documento/apostila.pdf (acesso em 28.04.2011)
} 
programas de governo, verificando se o planejamento estatal foi hábil a atender - com índices razoáveis de satisfatoriedade - as necessidades públicas. ${ }^{85}$

Essa análise de gestão empreendida pelo controle interno é fundamental para subsidiar os novos planos e programas estatais, uma vez que a atuação grosseira e ineficiente deve ser revista, aprimorada ou alterada, e não mais repetida.

Vale realçar que análise de eficiência não recai exclusivamente sobre a Administração. Ao controle interno compete, ainda, avaliar os resultados da aplicação de recursos públicos por entidades de direito privado. A dicção constitucional não está se referindo aos entes da administração indireta que se constituem sob a natureza de direito privado, pois tais figuras integram a Administração Pública. O texto constitucional alude, especialmente, às pessoas de direito privado que não integram os quadros administrativos, mas que, por qualquer razão, recebem recursos públicos.

A sindicância, mediante controle interno, das entidades de direito privado alcança a extensa temática da atuação do chamado terceiro setor, ou seja, pessoas jurídicas de direito privado que, em colaboração com Estado, exercem função de notório interesse coletivo, recebendo para tanto auxílios financeiros do Poder Público. Nesse particular, há um controle prévio de eficiência como pressuposto para a outorga de recursos financeiros. Os arts. 16 e 17 da lei 4.320 de 1964, que regulam a concessão de subvenções sociais, disciplinam que somente as entidades dotadas de padrões satisfatórios serão merecedoras do auxílio financeiro. Até mesmo o valor a elas repassado levará em conta índices mínimos de eficiência do serviço prestado ou posto à disposição. Assim, os órgãos de controle interno devem conferir inicialmente se as entidades são aptas a receber os recursos financeiros, e, posteriormente, haverão de verificar se os recursos foram aplicados adequadamente, procedendo-se, sobretudo, a uma análise de resultados quanto à aplicação do numerário repassado.

Outra das finalidades do controle interno é a sindicância das operações de crédito, avais e garantias, bem como a fiscalização dos direitos e haveres para com o Estado.

O constituinte demonstrou esmerada preocupação com o endividamento público, restringindo-o no art. 52, incisos VI a IX. Os dispositivos em questão versam sobre as competências do Senado Federal para limitar as operações de crédito no âmbito de

${ }^{85}$ Cf. MILESKI, Helio Saul. O Controle... p. 160 e 161. 
toda Federação. Logo, ao controle interno cabe verificar se a Administração observou as limitações impostas, certificando, ainda, o abatimento dos valores já saldados para evitar qualquer repetição no pagamento.

O controle interno também abarca a verificação dos haveres e direitos do ente controlado, fiscalizando adimplemento das obrigações financeiras para com o Poder Público. Evidencia-se, nesse caso, a preocupação com a preservação do patrimônio público, de modo que os órgãos devem atuar para impedir desfalques aos cofres públicos, buscando concretizar todas as receitas que o Estado puder auferir.

Por fim, o art. 74, IV, da CF remete à finalidade do controle interno de apoiar a missão institucional do controle externo. Os órgãos de controle interno estão nas entranhas do Poder controlado, possuem, desse modo, fácil acesso às informações e visualizam com maior clareza a atuação financeira do ente sindicado, razão pela qual devem propiciar um denso substrato material para a efetivação do controle externo. Nesse sentido, assevera Ricardo Lobo Torres que o controle interno é "preparatório do ulterior controle externo, que sem ele não pode ser eficientemente exercido." 86

Nesses termos, a Constituição prevê, no $\S 1^{\circ}$ do art. 74 , a responsabilidade solidária do agente de controle interno que não cientifica a constatação de qualquer irregularidade ou ilegalidade ao Tribunal de Contas. Essa previsão, além de reforçar a necessidade de apoio do controle interno ao externo, contribui, em larga medida, para a autonomia dos órgãos de controle interno.

Uma vez que o órgão de controle interno faz parte da estrutura administrativa de determinado Poder, há a probabilidade de que os agentes de controle sofram pressões e desmandos da autoridade administrativa superior. Logo, a expectativa de eventual responsabilidade solidária pelo acobertamento de irregularidades e ilegalidades faz com que os agentes do controle interno atuem com maior independência, desvencilhando-se de interferências que visam ocultar qualquer desvio na atuação financeira. ${ }^{87}$

Do exposto, é possível concluir que todas as finalidades constitucionais creditadas ao controle interno revelam um peculiar modo pelo qual a fiscalização será exercitada. De outra parte, o panorama constitucional descrito revela que a fiscalização mediante controle interno tem um assento orgânico preciso, ou seja, a sindicância

\footnotetext{
${ }^{86}$ TORRES, Ricardo Lobo. Tratado... p. 481 e 482.

${ }^{87}$ Cf. MILESKI, Helio Saul. O Controle... p. 162.
} 
financeira interna será exercida por um sistema integrado de órgãos mantido pelos três Poderes.

No mais, constata-se que a CF de 1988 não precisou a posição hierárquica dos órgãos de controle interno, muito menos indicou ou constituiu órgãos específicos para a realização desse tipo de controle. Dessa maneira, há que se reconhecer certo laconismo constitucional sobre a matéria, valendo a observação proferida por Ricardo Lobo Torres:

"Ao contrário do controle externo, minuciosamente regulado pela $C F$ e solidamente estruturado em torno do Tribunal de Contas e das Comissões do Congresso, o controle interno recebe diminuta atenção constitucional e legal, se pulveriza através de órgãos nem sempre bem organizados e conta com escassa bibliografia." 88

\subsection{O controle externo.}

A fiscalização financeira será exercitada, também, mediante o controle externo, sendo o elemento caracterizador desse tipo de controle o fato de que a sindicância das finanças estatais compete a um Poder distinto do controlado. Nessa linha, o art. 70 da Constituição Federal atribuiu o controle externo à competência do Congresso Nacional, a quem cabe fiscalizar a atuação financeira dos demais Poderes.

Adjudicar a função de controle externo das finanças públicas ao Congresso Nacional faz com que esse tipo de controle seja tipicamente legislativo. Cumpre advertir, contudo, que o Poder Legislativo exerce numerosas formas de controle sobre os demais Poderes. A título de exemplo, o art. 49, X, da Constituição demonstra um panorama abrangente do controle feito pelo Poder Legislativo ao prescrever que compete ao

${ }^{88}$ TORRES, Ricardo Lobo, Curso de Direito Financeiro e Tributário. 8. ed. Rio de Janeiro: Renovar, 2001, p. 185. 
Congresso Nacional: “X - fiscalizar e controlar, diretamente, ou por qualquer de suas Casas, os atos do Poder Executivo, incluídos os da administração indireta".

O citado preceito constitucional revela, por si só, a generalidade do controle que o Poder Legislativo exerce sobre a Administração Pública. Mas interessa notar, em especial, que a atividade financeira do Estado recebe um controle inafastável por parte do Parlamento. Cite-se, nesse sentido, todo o ciclo de elaboração e aprovação orçamentária. Os arts. 84, XXIII, c.c. 165, e incisos, da Constituição prescrevem que o Poder Executivo deve elaborar a proposta orçamentária e encaminhá-la para posterior análise e aprovação do Legislativo. Quando da apreciação, este último pode, com restrições, emendar a proposta encaminhada antes de aprová-la. ${ }^{89}$ Desse modo, o ciclo orçamentário revela o nítido controle financeiro exercido pelo Legislativo, pois este Poder não só confere seu assentimento, autorizando os gastos públicos, como também pode alterar a destinação dos recursos, emendando a proposta enviada pelo Executivo.

Do mesmo modo, o Poder Judiciário também se submete ao controle orçamentário exercido pelo Legislativo. Nos termos do art. 99, § $1^{\text {o }}$, da CF de 1988, os Tribunais elaboram suas propostas orçamentárias, encaminhando-as ao Executivo para que este as integre no projeto orçamentário que será submetido ao Legislativo. ${ }^{90}$ Ao fim e ao cabo, os recursos que subsidiam a estrutura e atuação do Poder Judiciário passam pelo controle do Poder Legislativo, competindo-lhe, assim, apreciar e autorizar os gastos que custeiam a função jurisdicional.

Ocorre, porém, que o controle externo, embora seja exercido pelo Legislativo, não se confunde com o controle parlamentar quando da apreciação e aprovação dos orçamentos. Nas lições de Paulo Bugarin: “O Controle Externo da Administração Pública insere-se entre as modalidades do chamado controle Parlamentar ou Legislativo, possuindo um conjunto de características e ocupando um bem definido espaço jurídicoconstitucional". 91

O controle externo encontra disciplina expressa na CF de 1988 que institui e indica os órgãos responsáveis pelo controle, dotando-lhes de competências precisas para

\footnotetext{
${ }^{89}$ Cf. art. $116, \S \S 3^{\circ}$ e $4^{\text {o }}$ da CF de 1988.

${ }^{90}$ Maurício Conti esclarece que a Constituição não deixa claro se a proposta orçamentária do Judiciário deve ser encaminhada ao Executivo, contudo, leis infraconstitucionais - no caso, as LDOs - determinam o envio da proposta ao Executivo. CONTI. José Maurício. A autonomia financeira do poder judiciário. São Paulo: MP editora, 2006. p. 87.

${ }^{91}$ BUGARIN, Paulo Soares. O Princípio... p. 37.
} 
levar a cabo a fiscalização financeira. Desse modo, a controle externo resta individualizado pelo constituinte, erigindo-se como um mecanismo específico de controle.

Em relação aos órgãos responsáveis, a Constituição prescreve, inicialmente, que controle externo será exercido pelo Congresso Nacional. Porém, a CF de 1988 concebe um órgão específico para auxiliar ao Legislativo nessa missão, aduzindo o caput do art. 71 que: “O controle externo, a cargo do Congresso Nacional, será exercido com o auxílio do Tribunal de Contas da União".

As competências e atribuições que a Constituição defere ao Congresso Nacional e ao Tribunal de Contas moldam a forma pela qual a fiscalização financeira será exercida mediante controle externo. Desse regime constitucional denota-se que a fiscalização se verifica posteriormente à aprovação do orçamento, completando, assim, o ciclo de controle que o Poder Legislativo exerce sobre a atividade financeira do Estado. ${ }^{92}$

Constata-se que, em grande medida, o controle externo volta-se à fiscalização da execução orçamentária, conferindo se a fixação dos gastos veiculada pelo orçamento foi corretamente observada. Dessa maneira, o controle externo visa impedir que os demais Poderes desvirtuem a destinação dos recursos públicos consignada na peça orçamentária, pois como destaca Aliomar Baleeiro: "De nada valeria a competência do Poder Legislativo para aceitar ou rejeitar o programa de governo, autorizar ou vedar receitas e despesas, se não tivesse meios e órgãos técnicos de fiscalização da execução orçamentária." 93

Do estatuto constitucional do controle externo extrai-se, também, a necessidade de uma fiscalização sobre todo o patrimônio público de modo que esse controle não fica restrito à execução orçamentária. Aduz, nesse sentido, a doutrina de José Mauricio Conti ao alinhavar que o controle externo "abrange essencialmente a fiscalização das contas e dos bens públicos". ${ }^{94}$

No entanto, verificar a exata extensão do controle externo sobre a execução orçamentária e sobre todo o patrimônio público depende da análise detida das atribuições que a Constituição arrola ao Congresso Nacional e ao Tribunal de Contas, razão pela qual segue um estudo sobre as competências de ambos no tocante à fiscalização financeira.

\footnotetext{
92 Nesse sentido Frances Vallés Vives: "Dicho de outro modo, la autoridad de imponer impuestos y de autorizar el gasto público, no significa un control completo. Para conseguirlo, deben asegurarse también los mecanismos mediante los quales se pueda comprobar que La voluntad legislativa ha sido efectivamente observada." VIVES, Francesc Vallés. El control... p.33.

${ }^{93}$ BALEEIRO, Aliomar. Uma introdução... p. 445.

${ }^{94}$ CONTI. José Maurício. A autonomia ... p. 112.
} 


\subsubsection{O controle externo exercido pelo Congresso Nacional.}

Os arts. 70 e seguintes estabelecem a configuração elementar do sistema constitucional de fiscalização da atividade financeira do Estado, consignando para tanto duas formas de controle pelos quais a fiscalização deve ser exercitada: um controle interno e um controle externo.

Como se expôs, a CF de 1988 reclama a configuração de um controle interno sistêmico e integrado no âmbito da físcalização que cada Poder exerce sobre si mesmo. Ademais, o Diploma Maior traça as finalidades do controle interno, sem, contudo, precisar ou instituir órgãos competentes para o exercício da fiscalização. De outra parte, a fiscalização mediante controle externo foi concebida para ser exercida por órgãos expressamente indicados: o Tribunal de Contas e o Congresso Nacional cujas competências estão fixadas no Texto Maior.

Percebe, entretanto, que a CF de 1988, nos arts. 71 e seguintes, regula com minúcias as atribuições e a composição do Tribunal de Contas, pautando-se pela concisão ao tratar da competência do Congresso Nacional para exercer controle externo.

Apenas o art. 72 confere alguma atribuição ao Congresso Nacional ao dispor:

"A Comissão mista permanente a que se refere o art. 166, $\$ 1^{\circ}$, diante de indícios de despesas não autorizadas, ainda que sob a forma de investimentos não programados ou de subsídios não aprovados, poderá solicitar à autoridade governamental responsável que, no prazo de cinco dias, preste os esclarecimentos necessários."

O art. 166, § $1^{\circ}$, da CF de 1988 fala na composição de uma Comissão mista, composta por Deputados e Senadores, à qual compete examinar previamente os projetos de emenda ao orçamento e as contas apresentadas pelo chefe do Executivo. Pela dicção do art. 72, soma-se à competência dessa Comissão a prerrogativa de solicitar informações diante de indícios de gastos não autorizados, ou ainda, quando da constatação de indícios de investimentos não programados e subsídios não aprovados pelo Legislativo. 
O conteúdo do art. 72, se individualmente considerado, indicaria a pusilanimidade do controle externo exercido pelo Congresso Nacional, pois um controle que se limitasse a solicitar informações seria por demais indulgente. No entanto, é preciso afirmar que a competência do Congresso Nacional para o controle externo não se circunscreve à disciplina dos arts. 70 e seguintes. Para tanto, reclama-se uma apreciação sistemática do texto constitucional no intuito de verificar quais são as atribuições próprias do Parlamento em matéria de controle externo financeiro.

Como se afirmou anteriormente, a estrutura constitucional do controle externo denota o exercício de uma fiscalização sobre a execução orçamentária, completando, assim, o ciclo de controle Legislativo na atividade financeira do Estado. Logo, o termo final desse controle - precisamente do controle externo - consiste no julgamento e aprovação das contas estatais. Anota com precisão Wremyr Scliar que: "No sistema brasileiro atual, o controle externo é atribuição do Poder Legislativo, a quem incumbe, em primeiro plano, o julgamento político das prestações de contas do Chefe do Poder Executivo." 95

De fato, conforme apregoa o art. 49, IX, da CF de 1988, a Constituição defere ao Congresso Nacional competência exclusiva para: "IX - julgar anualmente as contas prestadas pelo Presidente da República e apreciar os relatórios sobre a execução dos planos de governo;".

Além de julgar as contas apresentadas pelo Chefe do Executivo, nota-se que ao Congresso cabe apreciar a execução dos planos de governo. Ora, em larga medida, a apreciação da execução do planejamento governamental invoca uma análise financeira da atuação estatal. Constata-se que todo o planejamento governamental está baseado no planejamento orçamentário, assim escrevem Pederiva e Pontes: "Sabe-se que de um lado os 'planos de governo' são explicitados no Plano Plurianual, ou com esses interligados, detalhados nas Leis de Diretrizes Orçamentárias e executados mediante os Orçamentos Anuais." 96

A apreciação da execução dos planos de governo envolve, portanto, uma avaliação sobre o alcance e a eficácia da atuação estatal, verificando se os planos de

\footnotetext{
${ }^{95}$ SCLIAR, Wremyr. Controle externo brasileiro: Poder Legislativo e Tribunal de Contas. Revista de Informação Legislativa, Brasília, Ano. 46, nº 181, jan/mar, 2009. p. 252.

96 PEDERIVA, João Henrique e PONTES, João Batista. Contas prestadas pelo Presidente da República: apreciação do Congresso Nacional. Consultoria Legislativa do Senado Federal. Brasília, Textos para Discussão no 14. Ago. 2004. p. 7.
} 
governo e, conseqüentemente, se o planejamento e a execução orçamentária foram aptos a propiciar vantagens econômicas e sociais fruíveis pelos administrados. Ademais, essa apreciação permite um contraditório entre o Executivo e Legislativo pelo qual se torna possível contestar as ações de governo, propondo sugestões e alternativas que se mostrem mais efetivas para atender aos anseios da sociedade. ${ }^{97}$

Apreciar os planos de governo relaciona-se, intimamente, com o julgamento das contas do Chefe do Executivo. Esclarecem, mais uma vez, Pederiva e Pontes ${ }^{98}$ que o julgamento das contas pelo Parlamento consiste no acompanhamento da execução dos planos e ações de governo e da adequação desses para a consecução do bem comum. Nesse sentido, Poder Legislativo confere, mediante o julgamento, a sentença final sobre a atuação governamental, tendo em vista os resultados auferidos com planejamento da atividade financeira. Em outras palavras, o juízo acerca das contas do Chefe do Executivo comporta uma apreciação sobre o desempenho da Administração, constatando em que medida a atuação financeira, consubstanciada nos planos e programas governamentais, foi hábil a atender o interesse público.

Ressalte-se, contudo, que as contas submetidas ao julgamento do Poder Legislativo são apresentadas de forma global, abrangendo toda a Administração Pública com a inclusão dos três Poderes. Isso porque a Lei Complementar 101 de 2000, a LRF, prevê no art. 56 que as contas prestadas pelo Executivo, incluirão, além das suas próprias, as contas dos demais Poderes, bem como as do Ministério Público.

Nada mais natural, pois todos os Poderes são custeados por recursos públicos e têm seus gastos contemplados no planejamento e na execução orçamentária, razão pela qual suas respectivas contas devem constar da prestação global apresentada pelo Chefe do Executivo. ${ }^{99}$ Outrossim, conforme atesta Rosanne Mannarino ${ }^{100}$, a prestação global das contas pelo Executivo é mais condizente com a Constituição, pois o controle externo do Congresso Nacional abarca, sem dúvida, todos os Poderes.

\footnotetext{
${ }_{97}^{97}$ PEDERIVA, João Henrique e PONTES, João Batista. Contas prestadas... p. 8.

${ }^{98}$ Ibid. p.7.

${ }^{99}$ Questiona-se sobre o fato de o Chefe do Executivo ter o encargo de prestar suas próprias contas e as dos demais Poderes. Pederiva e Pedro respondem tal indagação, alegando: "O fato de a Constituição focalizar o dever do Presidente da República de prestar contas pode ser, assim, creditado à relevância que o Poder Executivo assume, no que se refere ao volume dos recursos destinados à prestação e ao fornecimento de bens, serviços e produtos que mais diretamente interessam à satisfação das necessidades públicas e à garantia das condições e da infra-estrutura fundamentais para o desenvolvimento do País" PEDERIVA, João Henrique e PONTES, João Batista. Contas ... p. 10.

${ }^{100}$ MANNARINO, Rosanne. Prestação de Contas do Governo da República. Para quem? A sociedade Brasileira?p. 230. In: SOUSA JÚNIOR, José Geraldo de (org.). Sociedade Democrática, direito público e controle externo. Brasília: TCU, 2006.
} 
No entanto, embora as contas prestadas sejam abrangentes, englobando a atuação financeira dos três Poderes, é preciso dizer que somente o Chefe do Executivo será, efetivamente, julgado pelo Congresso Nacional. Assim leciona Ricardo Lobo Torres: “Compete, pois, ao Congresso Nacional a responsabilidade final pelo controle externo. Só ele libera de responsabilidade o Presidente da República pela execução do orçamento." 101

Assevera-se que o Chefe do Executivo é o condutor do planejamento governamental, exercendo uma função notoriamente política, de modo que cabe ao Parlamento julgar a gestão financeira concebida e orientada por ele. Recorda Carrilho Chaves $^{102}$ que as contas do Chefe do Executivo têm um status constitucional evidente, já as contas dos outros Poderes assumem estatura legal, apenas. Segundo ele, o julgamento das contas do Chefe do Executivo pelo Parlamento assenta-se sobre bases macroeconômicas e sociais de modo a evidenciar um juízo puramente político, no qual a análise é muito mais subjetiva do que objetiva. Por outro lado, as contas dos demais Poderes submetem-se ao regime legal de metas e limites fiscais proclamados pela LRF, reclamando um julgamento objetivo pelo órgão técnico, qual seja, o Tribunal de Contas.

Desse modo, o juízo político exercido pelo Congresso quanto à aprovação das contas é dirigido unicamente ao Chefe do Executivo e consiste em uma avaliação global da condução política por ele efetivada. Logo, o julgamento das contas e a apreciação da execução dos planos de governo não se preocupam com detalhes da rotina administrativa, mas versam sobre o mérito das medidas e diretrizes adotadas para a consecução dos objetivos fundamentais do País. ${ }^{103}$

Vale destacar, nesse sentido, que: "o Chefe do Executivo, embora seja o condutor político dos planos de governo, não é, na acepção restrita do termo, executor do orçamento." 104 Segundo Helio Mileski, ${ }^{105}$ o Chefe do Executivo é o gestor do planejamento estatal, contudo, não lhe compete, pessoalmente, a execução dos orçamentos. Seus auxiliares e subordinados é que assumem a responsabilidade pela concretização do planejamento estatal, aplicando as dotações orçamentárias nos programas governamentais que supervisionam. Dessa maneira, o Chefe do Executivo, enquanto orientador da política

\footnotetext{
101 TORRES, Ricardo Lobo. Tratado ... p. 472.

102 CHAVES, Francisco Eduardo Carrilho. As contas do governo da República e os Tribunais de Contas.

Revista de Informação Legislativa, Brasília, Ano. 44, nº 1174, Abr/Jun, 2007. p.314.

${ }^{103}$ PEDERIVA, João Henrique e PONTES, João Batista. Contas ... p. 7.

${ }^{104}$ ARAUJO, Julio Cesar Manhães de. Controle ... p. 294.

${ }^{105}$ MILESKI, Hélio Saul. O Controle... p. 241.
} 
de governo, submete-se a um julgamento político pelo Parlamento, já seus auxiliares e subordinados estão sujeitos ao julgamento pelo Tribunal de Contas.

O mesmo se diga quanto ao julgamento das contas dos Poderes Judiciário e Legislativo. Ou seja, esses dois Poderes somente exercem funções administrativas interna corporis, suas respectivas atuações financeiras não estão sujeitas a uma avaliação de cunho político, submetendo-se integralmente ao juízo do Tribunal de Contas.

Especificamente, em relação ao Poder Judiciário, Maurício Conti afirma que: "Não há, pois, um julgamento específico das contas do Poder Judiciário, enquanto tal, pelo Poder Legislativo, (...). O que existe, nesse caso, é um julgamento das contas do Estado, que, nessa situação, é representado pelo chefe do Poder Executivo." 106 Entretanto, o autor reconhece que cabe ao Tribunal de Contas julgar as pessoas envolvidas na administração de bens e valores afeitos ao Judiciário.

Quanto às contas do Legislativo é um imperativo lógico reconhecer que um Poder não pode julgar a correção de suas próprias contas. Nesse sentido, o $\mathrm{STF}^{107}$ fixou a inconstitucionalidade de normas de Constituição Estadual que dispensava às contas apresentadas pelo Legislativo Estadual e Municipal o mesmo tratamento conferido ao julgamento das contas do Poder Executivo. A Corte Constitucional entendeu que o modelo apregoado na Constituição Federal, segundo o qual somente o Chefe do Executivo é julgado pelo Parlamento, deve ser observado pelos Estados e Municípios. Assim, as contas do Legislativo, embora apresentadas conjuntamente com as do Executivo, serão julgadas por um órgão independente, qual seja, o Tribunal de Contas, não merecendo uma avaliação política, a exemplo do que ocorre com Chefe do Poder Executivo.

Logo, o controle externo exercido motu proprio pelo Poder Legislativo debruça-se, em larga medida, sobre a atuação do Chefe do Poder Executivo e vai muito além da mera tomada de informações diante de indícios de irregularidades, tal como aduz o teor do art. 72 da CF. O Parlamento, mediante controle externo, acaba por sindicar os planos de governo e as contas estatais, emitindo, ao final, um julgamento sobre o Chefe do Executivo. Esse julgamento é global e confere chancela política à atuação do Chefe do Executivo quanto à condução geral do Estado, aprovando ou não as ações e os programas implementados na persecução do bem comum dos cidadãos.

\footnotetext{
${ }^{106}$ CONTI. José Maurício. A autonomia ... p. 116.

${ }^{107}$ BRASIL. Supremo Tribunal Federal. ADI 1779/PE. Rel. Min. Ilmar Galvão, j.01.08.2001, e, BRASIL. Supremo Tribunal Federal. ADI 1964/ES - MC. Rel. Min. Sepúlveda Pertence. . 25.03. 1999.
} 


\subsubsection{O controle externo exercido pelo Tribunal de Contas.}

Nos termos do art. 71 da CF de 1988, o controle externo, a cargo do Congresso Nacional, será exercido com o auxílio do Tribunal de Contas. A instituição desse tribunal não é uma novidade concebida pela atual Constituição. A configuração de uma Corte com propósito específico para sindicar os atos de gestão financeira da Administração Pública remonta a uma antiga tradição do ordenamento jurídico brasileiro.

A primeira Constituição brasileira, a Constituição de 1824, já previra, no art. 170, a instalação de um Tribunal, denominado "Thesouro Nacional”, ao qual incumbia a administração, arrecadação e contabilidade das receitas e despesas. ${ }^{108}$ Contudo, a instalação efetiva de um Tribunal de Contas só se deu com o advento da primeira Constituição Republicana, que no art. 89 dispunha: " $E$ instituído um Tribunal de Contas para liquidar as contas da receita e da despesa e verificar a sua legalidade, antes de serem prestadas ao Congresso."

Desde então, os Tribunais de Contas se consolidaram como instituições públicas nacionais, recebendo um tratamento destacado na CF de 1988. O Diploma Maior assevera, inicialmente, que cabe ao Tribunal de Contas prestar auxílio ao Congresso Nacional. Porém, constata-se adiante, que a Lei Maior comete competências exclusivas ao Tribunal de Contas, conferindo-lhe um status constitucional autônomo.

Nesse sentido, muito já se debateu sobre a natureza jurídica do Tribunal de Contas. ${ }^{109}$ Sob a égide de Constituições pretéritas, alguns já defenderam a natureza jurisdicional do Tribunal de Contas, alegando, em síntese, que essa Corte de Contas emite um julgamento sobre os administradores e responsáveis por bens e valores públicos. Mais recentemente, Ulisses Fernandes reconhece força judicante às decisões do Tribunal de Contas, escrevendo: “assim, sem laivo de dúvida, algumas funções das Cortes de Contas se inserem como judicantes, inibindo o reexame pelo Judiciário quanto ao mérito." 110

\footnotetext{
${ }^{108}$ In vebis: "Art. 170. A Receita, e despeza da Fazenda Nacional será encarregada a um Tribunal, debaixo de nome de 'Thesouro Nacional' aonde em diversas Estações, devidamente estabelecidas por Lei, se regulará a sua administração, arrecadação e contabilidade, em reciproca correspondencia com as Thesourarias, e Autoridades das Provincias do Imperio."

${ }^{109}$ Cf. MILESKI, Hélio Saul. O Controle... p. 205 a 212. e GUALAZZI, Eduardo Lobo Botelho. Regime Jurídico dos Tribunais de Contas. São Paulo: RT, 1992. p.174 a 187.

${ }^{110}$ FERNANDES, Jorge Ulisses Jacoby. Tomada de contas especial: processo e procedimento nos Tribunais de Contas e na Administração Pública. Brasília: Brasília Jurídica, 1996. p. 30.
} 
Em oposição, afirma Odete Medaur que: "Nenhuma das atribuições do Tribunal de Contas caracteriza-se como jurisdicional." 111 A autora entende que nenhuma lesão a direito pode ser excluída da apreciação do Judiciário, logo, não há decisão definitiva no âmbito das Cortes de Contas, pois todas podem ser revistas pelo Judiciário. Assim, as funções dos Tribunais de Contas teriam natureza administrativa, uma vez que padecem do caráter de definitividade que é inerente aos atos jurisdicionais.

Helio Mileski ${ }^{112}$, de se turno, tributa ao Tribunal de Contas uma jurisdição administrativa, pois, segundo ele, o poder de julgar as contas dos administradores públicos deriva de competência constitucional expressa, sendo possível, entretanto, a revisão de suas decisões pelo Judiciário.

Controvérsias à parte, o posicionamento de Mileski expõe uma constatação relevante: o Tribunal de Contas possui competências próprias estabelecidas pela CF de 1988. É preciso reconhecer que o constituinte dotou a Corte de Contas com atribuições precisas de modo a lhe conferir individualidade e autonomia em relação aos demais Poderes. Aponta Gualazzi ${ }^{113}$ que o Tribunal de Contas exerce, em relação aos três Poderes do Estado, competências exclusivas, privativas e indelegáveis, configurando-se como um órgão autônomo.

Portanto, o fato de que a Constituição coloca a Corte de Contas como auxiliar do Legislativo não é fator determinante para lhe retirar a autonomia, ou ainda, transformálo em um órgão subalterno do Parlamento. Confira, nesse diapasão, a doutrina de Carlos Ayres Britto: "o Tribunal de Contas da União não é órgão auxiliar do Parlamento Nacional, naquele sentido de inferioridade hierárquica ou subalternidade funcional." 114 Prossegue o autor:

“Em rigor de exame teórico ou apreciação dogmática, Poder Legislativo e Tribunal de Contas são instituições que estão no mesmo barco, em tema de controle externo, mas sob garantia de independência e imposição de harmonia recíproca. Independência, pelo desfrute de competências

\footnotetext{
${ }^{111}$ MEDAUAR, Odete. Controle... p. 142.

112 MILESKI, Hélio Saul. O Controle... p. 212.

${ }^{113}$ GUALAZZI, Eduardo Lobo Botelho. Regime Jurídico...p. 187.

${ }^{114}$ BRITTO, Carlos Ayres. O Regime Constitucional dos Tribunais de Contas. Revista Diálogo Jurídico, v. I, no. 9, dez, 2001. p. 3. Disponível em: <http://www.direitopublico.com.br〉. Acesso em: 17.06.2011.
} 
constitucionais que se não confundem (o que é de um não é do outro, pois dizer o contrário seria tornar inócua a própria explicitação enumerativa que faz a Constituição para cada qual dos dois órgãos públicos). Harmonia, pelo fim comum de atuação no campo do controle externo (...).

Tudo fica mais claro quando se faz a distinção entre competências e função. A função de que nos ocupamos é a mesma, pois outra não é senão o controle externo. As competências, no entanto, descoincidem." 115

É difícil dissentir das lições de Carlos Britto. De fato, tanto o Parlamento como o Tribunal de Contas exercem uma função comum de controle externo. No entanto, ambos possuem competências diversas. Desse modo, o Tribunal de Contas, embora auxiliar do Legislativo, não se configura como subalterno ou inferior hierárquico do Parlamento. A atribuição de competências distintas e específicas à Corte de Contas tem um sentido particular, ou seja, as competências constitucionalmente deferidas ao Tribunal de Contas adjudicam-lhe independência e autonomia para realizar uma peculiar função de controle externo.

Na exata medida da engenharia constitucional, a função de controle externo do Parlamento está centrada no julgamento das contas do Chefe do Executivo, exercendo, nesse particular, uma apreciação sobre a execução dos planos de governo e uma sindicância informativa sobre qualquer indício de irregularidade na execução da despesa prevista. Já o controle externo realizado pelo Tribunal de Contas está atrelado às atribuições específicas que o poder constituinte lhe cominou.

Assim, a fiscalização financeira exercida pelo Tribunal de Contas, mediante controle externo, assume um acento constitucional próprio, situando-se no âmbito das competências que a CF de 1988 prescreve à Corte de Contas, a saber:

“Art. 71. O controle externo, a cargo do Congresso Nacional, será exercido com o auxílio do Tribunal de Contas da União, ao qual compete:

\footnotetext{
${ }^{115}$ BRITTO, Carlos Ayres. O Regime Constitucional... p. 5 e 6.
} 
I - apreciar as contas prestadas anualmente pelo Presidente da República, mediante parecer prévio, que deverá ser elaborado em sessenta dias a contar de seu recebimento;

II- julgar as contas dos administradores e demais responsáveis por dinheiros, bens e valores públicos da administração direta e indireta, incluídas as fundações $e$ sociedades instituídas e mantidas pelo poder público federal, e as contas daqueles que derem causa a perda, extravio ou outra irregularidade de que resulte prejuízo ao erário público;

III- apreciar, para fins de registro, a legalidade dos atos de admissão de pessoal, a qualquer título, na administração direta e indireta, incluídas as fundações instituídas e mantidas pelo poder público, excetuadas as nomeações para cargo de provimento em comissão, bem como a das concessões de aposentadorias, reformas e pensões, ressalvadas as melhorias posteriores que não alterem o fundamento legal do ato concessório;

IV- realizar, por iniciativa própria, da Câmara dos Deputados, do Senado Federal, de comissão técnica ou de inquérito, inspeções e auditorias de natureza contábil, financeira, orçamentária, operacional e patrimonial, nas unidades administrativas dos Poderes Legislativo, Executivo e Judiciário, e demais entidades referidas no inciso II;

$V$ - fiscalizar as contas nacionais das empresas supranacionais de cujo capital social a União participe, de forma direta ou indireta, nos termos do tratado constitutivo;

VI- fiscalizar a aplicação de quaisquer recursos repassados pela União, mediante convênio, acordo, ajuste ou outros instrumentos congêneres, a Estado, ao Distrito Federal ou a Município; 
VII- prestar as informações solicitadas pelo Congresso Nacional, por qualquer de suas Casas, ou por qualquer das respectivas comissões, sobre a fiscalização contábil, financeira, orçamentária, operacional e patrimonial e sobre resultados de auditorias e inspeções realizadas;

VIII- aplicar aos responsáveis, em caso de ilegalidade de despesa ou irregularidade de contas, as sanções previstas em lei, que estabelecerá, entre outras cominações, multa proporcional ao dano causado ao erário;

IX- assinar prazo para que o órgão ou entidade adote as providências necessárias ao exato cumprimento da lei, se verificada ilegalidade;

$X$ - sustar, se não atendido, a execução do ato impugnado, comunicando a decisão à Câmara dos Deputados e ao Senado Federal;

XI- representar ao Poder competente sobre irregularidades ou abusos apurados."

Inicialmente, a competência do Tribunal de Contas veiculada no art. 71, I, da CF de 1988 está sobremaneira relacionada com a atribuição do Poder Legislativo de julgar, mediante controle externo, as contas do Chefe do Executivo. Da dicção do preceito depreende-se que o julgamento das contas do Chefe do Executivo pelo Parlamento fica a depender da observância de um requisito constitucional inafastável, qual seja, a apreciação das contas pelo Tribunal de Contas por meio da emissão de um parecer prévio.

Carrilho Chaves anota que o parecer prévio da Corte de Contas é indispensável, pois “faz parte do devido processo legal aplicável ao julgamento das contas de governo." 116 Nessa linha, o STF sacramentou a imprescindibilidade do parecer prévio para o julgamento das contas ao definir a inconstitucionalidade de preceito da Constituição do Estado de Santa Catarina que dispensava o parecer prévio da Corte de Contas para o julgamento de Chefe do Executivo Municipal. No voto condutor, da lavra do Ministro Gilmar Mendes, argumentou-se que: “ao dispensar o parecer prévio do Tribunal de

$\overline{116}$ CHAVES, Francisco Eduardo Carrilho. As contas... p. 311. 
Contas, na espécie, alterou-se, significativamente, o sistema de controle previsto na Carta Magna." 117

O parecer prévio permite que o Tribunal de Contas aprecie os aspectos técnicos e jurídicos da condução administrativa, revelando a real situação econômico-financeira do Estado no sentido de fornecer informações gerenciais que possam subsidiar a decisão do Poder Legislativo quanto à aprovação ou desaprovação das contas apresentadas pelo Chefe do Executivo.

De fato, o juízo do Poder Legislativo sobre as contas de governo tem um caráter eminentemente político, o que não impede, contudo, que uma avaliação de ordem técnica e jurídica sobre a condução dos negócios públicos possa contribuir para formar a convicção dos parlamentares.

Em prestígio a essa autonomia política do Parlamento para julgar o Chefe do Executivo, o parecer prévio emitido pela Corte de Contas não possui um caráter definitivo e determinante, ou seja, a apreciação das contas exarada no parecer prévio não vincula o julgamento perpetrado pelo Legislativo. Nesse particular, a função do Tribunal de Contas é meramente opinativa, fornecendo um substrato técnico que auxilia o Parlamento a avaliar a conduta governamental empreendida pelo Chefe do Executivo.

O entendimento exposto encontra respaldo nas lições de Helio Mileski, que afirma: "tendo o parecer função meramente opinativa e de assessoramento ao Poder Legislativo, as recomendações realizadas em seu relatório não têm o condão de serem impostas coercitivamente à Administração." 118

O autor também rebate as críticas suscitadas pelo caráter político e amplamente discricionário do julgamento parlamentar em relação aos atos do Chefe do Executivo. Para Mileski, o Chefe do Executivo não executa, por si mesmo, o orçamento, cabendo-lhe a direção geral do Estado e dos planos de governo e, desse modo, é compreensível que lhe seja destinado um juízo de índole política. ${ }^{119}$

Assiste razão ao citado autor. Ora, quem executa o orçamento - aplicando as dotações nos respectivos planos e programas de governos - são os auxiliares e subordinados do Chefe do Poder Executivo, bem como aqueles servidores dos demais Poderes que são responsáveis pelo manuseio direto de bens e recursos públicos. Para essas

\footnotetext{
${ }^{117}$ BRASIL. Supremo Tribunal Federal. ADI 261-9/SC. Rel. Min. Gilmar Mendes, j.14.11.2002.

${ }^{118}$ MILESKI, Hélio Saul. O Controle... p. 269.

${ }^{119}$ Ibid. p, 267 e 270.
} 
pessoas, a CF de 1988 prevê, expressamente, um julgamento objetivo a cargo do Tribunal de Contas, consoante a disposição do art. 71, II.

É preciso distinguir com exatidão as competências do Tribunal de Contas e do Parlamento quanto ao julgamento de contas. Reconhece-se, assim, uma atribuição política do Legislativo para julgar as contas do Chefe do Executivo e uma competência exclusiva do Tribunal de Contas para julgar os demais administradores e responsáveis por bens e valores públicos. A Corte Constitucional é fiadora dessa distinção, aludindo, ainda, que o julgamento efetuado pelo Tribunal de Contas não se sujeita a posterior confirmação pelo Legislativo, assim atesta a ementa da ADI/MC no 3.715-3/TO:

"No âmbito das competências institucionais do Tribunal de Contas, o Supremo Tribunal Federal tem reconhecido a clara distinção entre: 1) a competência para apreciar e emitir parecer prévio sobre as contas prestadas anualmente pelo chefe do Poder Executivo, especificada no art. 71, I, CF/1988; 2) e a competência para julgar as contas dos demais administradores e responsáveis, definida no art. 71, II, CF/1988. Precedentes. Na segunda hipótese, o exercício da competência de julgamento pelo Tribunal de Contas não fica subordinado ao crivo posterior do Poder Legislativo." 120

O art. 71, II, da CF de 1988 confere, a seu turno, uma competência exclusiva ao Tribunal de Contas para julgar os administradores e demais responsáveis por bens e valores públicos. Essa competência levanta inúmeras controvérsias acerca da natureza jurídica deste julgamento, no entanto, importa analisar o teor dessa atribuição constitucional no intuito de definir os contornos institucionais da atuação do Tribunal de Contas.

Pode-se dizer, de plano, que o Tribunal de Contas profere um julgamento, deliberando sobre a atuação daqueles que administram ou gerenciam bens e recursos públicos. Ressalte-se que esse julgamento não é meramente declaratório, pois está

\footnotetext{
${ }^{120}$ BRASIL. Supremo Tribunal Federal. ADI 261-9/SC - MC. Rel. Min. Gilmar Mendes, j.26.05.2006.
} 
acompanhado de prerrogativas sancionadoras, conforme disciplina o art. 71, VIII, da CF de 1988, pelo qual compete à Corte de Contas: "aplicar aos responsáveis, em caso de ilegalidade de despesa ou irregularidade de contas, as sanções previstas em lei, que estabelecerá, entre outras cominações, multa proporcional ao dano causado ao erário;”.

Vale notar, também, que o juízo do Tribunal de Contas não é político e, conseqüentemente, não se baseia em uma apreciação amplamente discricionária, tal como o julgamento efetuado pelo Parlamento. A decisão do Tribunal de Contas é predominantemente objetiva, atendo-se aos aspectos da legalidade, legitimidade e economicidade presentes no caput do art. 70 da CF de 1988.

Como professa Carlos Britto, os Tribunais de Contas "julgam sob critério exclusivamente objetivo ou da própria técnica jurídica (subsunção de fatos e pessoas à objetividade das normas constitucionais e legais)." ${ }^{121}$ Nessa esteira, o Tribunal de Contas revela-se como uma instância específica de julgamento quanto ao emprego, guarda e gestão de bens e recursos públicos. Isso porque o conteúdo decisório pronunciado pelo Tribunal de Contas é, até certo ponto, intangível, obstando uma atuação mais contundente do Poder Judiciário.

Percebe-se que a nenhum outro órgão constitucional foi dada a competência para julgar as contas daqueles que são responsáveis pela guarda e gestão de bens e valores públicos, logo, seria uma excrescência permitir que o Judiciário pudesse reapreciar as decisões tomadas pela Corte de Contas. Argumenta com precisão Julio Cesar de Araujo:

“Aqui é de se lembrar que seria verdadeiro 'bis in idem' se o Tribunal pudesse julgar as contas e o Poder Judiciário as apreciar de novo, agora para emprestar o selo da definitividade. Simplesmente a existência dessa competência ao Tribunal de Contas seria uma redundância inútil." 122

O julgamento efetivado pelo Tribunal de Contas não pode ser turbado pelo Poder Judiciário. Não cabe a esse Poder alterar a decisão de mérito expressa por meio do

\footnotetext{
${ }^{121}$ BRITTO, Carlos Ayres. O Regime Constitucional... p. 8.

122 ARAUJO, Julio Cesar Manhães de. Controle ... p. 307.
} 
julgamento de contas, uma vez que essa atribuição constitucional é deferida com exclusividade ao Tribunal de Contas.

No entanto, a definitividade conferida ao julgamento realizado pelo Tribunal de Contas é relativa. É preciso reconhecer que o Judiciário exerce um controle de contornos sobre a atuação do Tribunal de Contas, sem, contudo, invadir a valoração de mérito que embasou a decisão da Corte de Contas.

Como bem aponta Helio Mileski ${ }^{123}$, a revisão judicial das decisões proferidas pela Corte de Contas está limitada aos aspectos da ilegalidade manifesta e do erro formal. Nesses termos, o Judiciário estaria habilitado a examinar o mérito da decisão única e exclusivamente para comprovar a validade legal do pronunciamento proferido pela Corte de Contas. Pode ocorrer que o julgamento de contas adote por fundamento um referencial jurídico equivocado ou uma incorreta apreciação fática. Nesses casos, o Judiciário poderia aferir tão somente a validade do julgamento proferido por esta Corte, abstendo-se, no entanto, de julgar definitivamente as contas. Em outras palavras, o Judiciário emite apenas uma decisão declaratória, invalidando o julgamento, sem emitir um juízo concreto acerca da responsabilidade daqueles que se submetem à competência judicante do Tribunal de Contas. $^{124}$

Ademais, o Poder Judiciário pode verificar a higidez procedimental da manifestação exarada pelo Tribunal de Contas, fulminando os julgamentos que não observaram as garantias processuais. Nesse particular, o provimento judicial pode ser inclusive mandamental, compelindo o Tribunal a atuar em conformidade com o devido processo legal. ${ }^{125}$

É elucidativa, nesse pormenor, a Súmula Vinculante $n^{\circ} 3$ do STF, que impõe a observância do contraditório e da ampla defesa nos processos perante o TCU, quando a decisão da Corte de Contas puder resultar em anulação ou revogação de ato administrativo que beneficie o interessado.

Mas, mesmo considerando essa interferência do Judiciário, o Tribunal de Contas afirma-se, constitucionalmente, como sede específica para julgar as contas

\footnotetext{
${ }^{123}$ MILESKI, Hélio Saul. O Controle... p. 282.

${ }^{124}$ ARAUJO, Julio Cesar Manhães de. Controle ... p. 310.

125 O STF emitiu farta jurisprudência ao apreciar a correção do devido processo legal em procedimentos realizados pelo TCU. Exemplificativamente: BRASIL. Supremo Tribunal Federal. MS 24353-8/DF. Rel. Min. Ellen Gracie, j.20.02.2003; e, BRASIL. Supremo Tribunal Federal. ADI 23919-1/DF. Rel. Min. Carlos Velloso, j.24.10.2002.
} 
públicas, mais precisamente, nas palavras de Julio de Araujo ${ }^{126}$, o Tribunal de Contas é o juiz natural das contas, competindo-lhe auferir a correção de condutas daqueles que lidam com bens e valores públicos.

Como se sabe, as contas do Chefe do Executivo são julgadas pelo Poder Legislativo, assim, cabe indagar sobre aqueles que se sujeitam ao juízo da Corte de Contas. $\mathrm{O}$ art. 71, II, assevera, inicialmente, que compete ao Tribunal de Contas julgar as contas dos administradores e demais responsáveis por bens e valores públicos da Administração Direta e Indireta. E, não obstante as fundações e as sociedades mantidas pelo Poder Público estejam inseridas no âmbito da Administração Indireta, o citado dispositivo constitucional faz questão de reforçar - para não deixar qualquer dúvida - que os gestores dessas entidades também se submetem ao julgamento de contas.

Ocorre que antes da CF de 1988 o julgamento de contas recaía exclusivamente sobre a figura do ordenador de despesa que, nos termos do art. 80, $\S 1^{\circ}$, do Dec. Lei 200 de 1967, é “qualquer autoridade de cujos atos resultarem emissão de empenho, autorização de pagamento, suprimento ou dispêndio de recursos da União ou pela qual esta responda."

Nota-se que o ordenador de despesa é o responsável direto pela execução orçamentária, ou seja, é a autoridade que tem o poder de determinar a efetivação do gasto público contemplado no orçamento, gerenciando as dotações colocadas à disposição de determinada unidade administrativa. Ele continua sendo figura de destaque na atual sistemática do julgamento de contas, uma vez que lhe toca uma parcela significativa da atividade financeira do Estado, qual seja, a execução da despesa pública. No entanto, o preceito do art. 71, II, da CF de 1988, além de abarcar os ordenadores de despesa, estendeu a competência de julgamento do Tribunal de Contas para todos os administradores e responsáveis por bens e valores públicos.

Nas lições de Helio Mileski:

"a expressão constitucional 'administradores e demais responsáveis por dinheiros, bens e valores públicos' envolve responsabilidade mais ampla que a ordenação de despesas, na medida em que abrange não só a realização de despesas,

${ }^{126}$ ARAUJO, Julio Cesar Manhães de. Controle ... p. 311. 
mas também a arrecadação da receita e todos os demais atos ou funções que possam ser caracterizados como fatores de utilização, arrecadação, guarda, gerência ou administração de dinheiros, bens e valores públicos, submetendo-se também à obrigação constitucional de prestar contas, por meio do processo de tomada de contas, cuja competência de julgamento pertence ao Tribunal de Contas" 127

Mas a constatação de que a Constituição ampliou consideravelmente o espectro de pessoas que devem prestar contas e, conseqüentemente, se submeter ao julgamento perpetrado pelo Tribunal de Contas, não se resume na expressão "administradores $e$ demais responsáveis por dinheiros, bens e valores públicos". É preciso consignar que a redação final do inciso II do art. 71 coloca sob a competência julgadora do Tribunal de Contas todos aqueles que "derem causa a perda, extravio ou outra irregularidade de que resulte prejuízo ao erário público;",

O dispositivo constitucional, em sua integralidade, submete ao jugo do Tribunal de Contas não só os agentes públicos diretamente responsáveis por gerir bens e valores públicos, mas também todos aqueles que de alguma forma causem danos e prejuízos ao erário público. A amplitude do preceito é tamanha que leva à conclusão de que pessoas privadas - que não compõem os quadros da Administração - podem ser julgadas pela Corte de Contas, quando na gestão dos recursos públicos, derem causa a qualquer tipo de ônus para o erário. ${ }^{128}$ Pode-se invocar, nesse aspecto, a síntese lapidar de Régis de Oliveira, quando afirma que o inciso II do art. 71 "outorga competência ao Tribunal de Contas para analisar e julgar todas as contas daqueles, que, de alguma forma, tenha lidado com dinheiro público." 129

\footnotetext{
${ }^{127}$ MILESKI, Hélio Saul. O Controle... p. 287.

${ }^{128}$ Reforça a jurisprudência do STF, ao consignar na ementa do MS 21644/DF o que segue: “3. O dever de prestar contas, no caso, não é da entidade, mas da pessoa física responsável por bens e valores públicos, seja ele agente público ou não. 4. Embora a entidade seja de direito privado, sujeita-se à fiscalização do Estado, pois recebe recursos de origem estatal, e seus dirigentes hão de prestar contas dos valores recebidos; quem gere dinheiro público ou administra bens ou interesses da comunidade deve contas ao órgão competente para a fiscalização. 5. Hipótese de competência do Tribunal de Contas da União para julgar a matéria em causa, a teor do art. 71, II, da Constituição, havendo apuração dos fatos em procedimentos de fiscalização, assegurada ao impetrante ampla defesa." BRASIL. Supremo Tribunal Federal. MS 21644-1/DF. Rel. Min. Néri da Silveira. j. 04.11.1993.

${ }^{129}$ OLIVEIRA, Régis de. Fiscalização Financeira... p.218.
} 
Convém notar que a competência julgadora do Tribunal de Contas é instituída como o objetivo de preservar o patrimônio público e os recursos do erário, garantindo que toda atividade de guarda, dispêndio e gestão de recursos e bens se submeta aos ditames do ordenamento jurídico, em especial, aos princípios da legalidade, da legitimidade e da economicidade. Assim, para dar efetividade a essa missão, a CF de 1988 houve por bem atribuir outras competências ao Tribunal de Contas, dotando-o, expressamente, de poderes fiscalizatórios, pois o poder de julgar as contas restaria prejudicado, se ao Tribunal de Contas não fosse reconhecida a competência para fiscalizar e apurar qualquer tipo de incorreção no trato com o patrimônio público.

Há, desse modo, competências instrumentais que fornecem subsídios para o êxito do julgamento realizado pela Corte de Contas. Nesse sentido, o constituinte circunscreveu ao Tribunal de Contas uma série de atribuições sindicantes, que, além de identificar as irregularidades, reforçam a instrução probatória e fática que comporta o julgamento de contas.

Dispõe nessa esteira o inciso IV do art. 71 que defere ao Tribunal de Contas a prerrogativa de realizar - por iniciativa própria ou a pedido das Casas e comissões do Parlamento - inspeções e auditorias de natureza contábil, financeira, orçamentária, operacional e patrimonial, nas unidades administrativas dos Poderes Legislativo, Executivo e Judiciário, e demais entidades, públicas ou privadas, que derem causa a perda ou extravio de bens e valores públicos.

Logo, a fiscalização pelo Tribunal de Contas desdobra-se em procedimentos próprios - as inspeções e as auditorias - pelos quais se torna possível apurar qualquer irregularidade, bem como subsidiar a instrução do julgamento das contas, buscando informações e esclarecimentos que conduzam à correta apuração da responsabilidade dos administradores e demais responsáveis por bens e valores públicos. ${ }^{130}$

Mas interessa notar que a competência sindicante do Tribunal de Contas alcança os recursos da pessoa política que integra onde quer que estejam. Permite-se, nesse particular, que o TCU possa fiscalizar a gestão dos recursos federais repassados a outras unidades federativas, conforme expressa disposição do inciso VI do art. 71. Assim, cabe aos gestores públicos dos Estados e Municípios prestarem contas e, conseqüentemente, responderem ao TCU pelo gerenciamento de verbas federais.

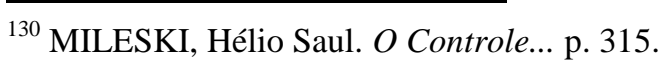


Esclareça-se que a competência do TCU para sindicar os repasses da União aos demais entes da Federação só vale em relação aos repasses voluntários. Em alguns casos, a União efetua, por determinação constitucional, repasses obrigatórios aos entes federativos; essas transferências compulsórias integram os recursos próprios do ente, logo, sua fiscalização compete ao Tribunal de Contas do respectivo Estado ou Município. Atesta, nesse aspecto, a posição do STF, assegurando que somente os repasses voluntários da União serão fiscalizados pelo TCU. ${ }^{131}$

De outra parte, a amplitude da fiscalização exercida pelo TCU alcança, também, as empresas de caráter supranacional de cujo capital social a União participe de forma direta ou indireta. Segundo o inciso V do art. 71 cabe ao TCU fiscalizar tais empresas, porém, para resguardar a soberania de outros Países envolvidos na formação da empresa supranacional, é preciso que a Corte de Contas observe os limites consignados no Tratado constitutivo.

Outrossim, o inciso III do art. 71 dota o Tribunal de Contas com uma atribuição fiscalizatória bem precisa. Dispõe o preceito que cabe à Corte de Contas apreciar, para fins de registro, os atos de admissão de pessoal da administração direta e indireta, inclusive os atos de concessão de aposentadorias, reformas e pensões.

Entretanto, por expressa menção constitucional, excluem-se do âmbito de competência do Tribunal de Contas as nomeações para cargos de provimento em comissão. Essa exceção indica, de certo modo, a ratio da sindicância dos atos de admissão de pessoal e concessão de aposentadorias. Quer-se garantir a higidez do processo de ingresso no serviço público efetivo, bem como a comprovação da legalidade na concessão de aposentadorias e pensões dos servidores inativos.

Sem dúvida, o custeio do pessoal creditado junto ao serviço público configurase em um pesado ônus aos cofres públicos, reclamando uma sindicância vigorosa com o intuito de verificar qualquer incorreção nas despesas com servidores. Ademais, o regime da LRF impõe limites rígidos para gasto com pessoal da Administração, evidenciando ainda mais a função do Tribunal de Contas em relação ao controle dos atos de admissão e concessão de aposentadorias e pensões.

Mas diante de todo o plexo de competências fiscalizatórias expostas, é preciso dizer que essas atribuições possuem um caráter instrumental evidente. Em primeiro lugar,

${ }^{131}$ Cf. BRASIL. Supremo Tribunal Federal. ADI 1934-7/DF-MC. Rel. Min. Moreira Alves. j. 01.09.1999.; e, BRASIL. Supremo Tribunal Federal. MS 224312-2/DF. Rel. Min. Hellen Gracie. j. 19.02.2003. 
prestam-se a identificar qualquer irregularidade quanto à gestão global de bens e valores públicos, pois não haveria sentido em fiscalizar, se não houvesse a adoção de medidas capazes de impedir, corrigir e sancionar condutas que em nada se coadunam com a boa gestão pública.

Assim, cabe ao Tribunal de Contas julgar os administradores e responsáveis por bens e valores públicos, bem como aqueles que deram causa a prejuízos ao erário, impondo-lhes as sanções previstas. Mas, não obstante essa competência julgadora, sobressai do Texto Constitucional a possibilidade do Tribunal de Contas emitir recomendações corretivas que orientam a atividade administrativa, afastando-a de eventuais irregularidades.

Em alguns casos, a conduta irregular não enseja a sanção imediata daqueles que estão sujeitos ao jugo do Tribunal de Contas, sendo que a simples recomendação da Corte de Contas se mostra mais eficaz e adequada para sanar determinadas incorreções no trato com o patrimônio público.

Julio de Araujo $^{132}$ aponta que as recomendações prestam-se a corrigir irregularidades, nas quais não se vislumbra a culpa do administrador nem a lesão efetiva ao erário. Nesse caso específico, uma atuação sancionadora do Tribunal de Contas se mostraria por demais desarrazoada, sendo de melhor conveniência determinar a emenda do equívoco constatado.

Acrescenta o autor que a função do Tribunal de Contas não se reduz a verificar a legalidade estrita, mas possui também “aspectos muito mais amplos e plásticos" pelos quais se torna possível, mesmo patente a ilegalidade, adotar medidas corretivas, sem a aplicação de sanções.

O fundamento constitucional dessa prática corretiva está expresso no inciso IX do art. 71, pelo qual compete ao Tribunal de Contas assinar prazo para que o órgão ou entidade tome as medidas necessárias ao cumprimento da lei, se verificada a ilegalidade. Logo, não necessariamente a conduta ilícita será sancionada, deferindo-se à Corte de Contas a possibilidade de emitir recomendações profiláticas que conduzam a atividade administrativa à correção propugnada pela ordem jurídica.

Inclusive, poderá a Corte de Contas, a teor do inciso X do art. 71, sustar o ato impugnado se não atendidas as providências necessárias para sanar a ilegalidade. No que

${ }^{132}$ ARAUJO, Julio Cesar Manhães de. Controle ... p. 360 e 361. 
tange aos contratos, por força do $\S 1^{\circ}$ do citado artigo, caberá ao Congresso sustar o ato impugnado pelo Tribunal de Contas e determinar as medidas cabíveis ao Executivo. Somente após inércia do Poder Legislativo, ou mesmo do Executivo em relação às recomendações fixadas, é que o Tribunal de Contas poderá sustar o ato eivado de ilegalidade.

Por fim, constata-se que o constituinte cometeu ao Tribunal de Contas a tarefa de informar ao Poder competente acerca das irregularidades e abusos apurados. Consoante disposto no inciso XI do art. 71, o Tribunal de Contas deve levar ao conhecimento do Poder interessado os abusos e irregularidades constatados a fim de que a autoridade administrativa possa impor sanções que fogem à competência da Corte de Contas.

De posse da representação do Tribunal de Contas, o Poder competente poderá promover as sanções de ordem administrativa, apurando as faltas disciplinares, bem como ajuizar eventual ação civil para o ressarcimento dos prejuízos causados. Ainda, poderá requisitar ao Ministério Público que tome as medidas cabíveis para o ajuizamento de possível ação penal. 


\section{II - A NOÇÃO DE LEGITIMIDADE DO ART. 70 DA CF DE 1988.}

\section{CONCEITO DE LEGITIMIDADE.}

O conceito de legitimidade é equívoco e não comporta, portanto, uma única acepção. Ribamar Caldas Furtado aponta, nesse sentido, três acepções diferentes ao termo "legitimidade". Segundo ele:

“No uso comum, o termo 'legitimidade’ tem três acepções: a) a de justiça ou racionalidade (fala-se, por exemplo, em 'legítimo interesse'); b) a de verdadeiro, genuíno, originário (diz-se que 'a peça do veículo é legítima'); c) a de atributo de poder ('o Estado é legitimado para cobrar tributos')." 133

Percebe-se das lições citadas, que a palavra "legitimidade" pode assumir um significado mais coloquial e ordinário. O uso do vocábulo "legitimidade", nesse particular, é empregado no sentido de verdadeiro, genuíno e serve para qualificar um objeto, expressando que sua origem não é fraudulenta. Fala-se, portanto, que determinada coisa é legítima, porque ela não é defraudada, tem procedência lícita e não é, de modo algum, falsificada.

É preciso destacar, todavia, que o excerto citado enuncia outros dois sentidos de legitimidade muito caros às ciências políticas. Evocar que a legitimidade é um atributo do poder estatal, ou, que se confunde com o senso de justiça faz parte das lições propedêuticas da Teoria Geral do Direito e do Estado, bem como da Filosofia Política. Confira-se, por exemplo, as lições do "Dicionário de Política" 134 que atribui à legitimidade dois significados distintos: um genérico relativo à idéia de justiça e racionalidade; e outro específico que a define como um atributo do poder do Estado.

\footnotetext{
${ }^{133}$ FURTADO, José Ribamar Caldas. O controle de legitimidade do gasto público. Fórum de Contratação e Gestão Pública, Belo Horizonte, Ano 5, n. 54, jun. 2006. p.7298.

${ }^{134}$ BOBBIO, Norberto; MATTEUCI, Nicola; e PASQUINO, Gianfranco. Dicionário de Política. $7^{\mathrm{a}}$ ed. Brasília: UNB, 1993. p. 675.
} 
Em relação ao sentido específico, é preciso reconhecer que o significado de legitimidade adquire um notório viés político e sociológico. A legitimidade, enquanto atributo do poder estatal, consubstancia-se como o fundamento do próprio poder, pois funciona como elemento de integração entre a sociedade e a autoridade emanada do Estado. Bem anota Bonavides ${ }^{135}$, amparado nas lições de Georges Vedel, que a legitimidade é o fundamento do poder em determinada sociedade e, de acordo com ela, os cidadãos decidem pela obediência ou desobediência ao poder instituído.

Nesse aspecto, a legitimidade é fator determinante para ensejar a adesão da população às ordens e institutos veiculados pelo Estado. Em outras palavras, é a crença na legitimidade do poder estatal que leva os cidadãos a reconhecerem o Estado como tal e, conseqüentemente, a se submeter à sua autoridade.

Há, portanto, uma constante universal na história política dos povos que faz com que todos os governos busquem meios para justificar, ou melhor, legitimar a detenção e o exercício do poder. Isso porque as comunidades humanas de todos os tempos não se sentem satisfeitas quando se submetem a uma autoridade que não seja legítima, pelo contrário a repelem e se revoltam contra ela. Entretanto, ao longo da história não é possível identificar um padrão único que possa caracterizar um governo como legítimo. ${ }^{136}$

Fábio Konder Comparato ${ }^{137}$ dá conta que o primeiro uso moderno do termo "legitimidade" foi feito por Talleyrand, logo após a Revolução Francesa. Usou-se o vocábulo "legitimidade" para qualificar positivamente o Ancien Régime e rejeitar, por conseguinte, todas as mudanças ocorridas com a revolução. No caso, a legitimidade do sistema político anterior à Revolução Francesa residia na sua consagração histórica. Explicava Talleyrand que o Antigo Regime era legítimo, pois se afirmara com decurso do tempo, tal como ocorre entre os particulares e o direito de propriedade. Ou seja, a legitimidade do poder residia no decurso do tempo. Logo, tanto mais legítimo seria o título para o exercício do poder, quanto mais antigo o fosse.

\footnotetext{
${ }^{135}$ BONAVIDES. Paulo. Ciência Política. 13 ed. São Paulo: Malheiros, 2006. p. 125

${ }^{136}$ Nesse sentido: "The desire of legitimacy is so deeply rooted in human communities in general that it is hard to discovery any sort of government in history that did not either enjoy widespread authentic recognition of its being or try to become legitimate. The universality of this phenomenon, however, is checked and also continuously endangered by the plurality of patterns and sources of legitimacy." STERNBERGER. Dolf. Typologie de la Légitimité. In: Annales de Philosophie Politique n.7: L'idée de Légitimité. Paris: Press Universitaires de France, 1967. p. 87.

${ }^{137}$ COMPARATO, Fábio Konder. Sobre a Legitimidade das Constituições. In: BONAVIDES, Paulo e outros (coord.) Constituição e Democracia: estudos em homenagem ao Prof. J.J. Gomes Canotilho. São Paulo: Malheiros, 2008. p. 68.
} 
Max Weber ${ }^{138}$ possui um clássico magistério sobre o tema da legitimidade do poder estatal. Para ele, aquilo que seja a dominação legítima pode ser classificada em três “tipos puros”. A vigência do poder legítimo seria, então, de índole racional, tradicional e carismática. A ordem legítima racional reconhece o direito de mando daqueles que são nomeados por meio de uma ordem estatutária (dominação legal). Já a legitimação do poder pela tradição baseia-se na crença da autoridade daqueles que exercem o poder em virtude de costumes imemoriais (dominação tradicional). Por fim, atribui-se legitimidade ao poder firmado pelo carisma, ou seja, as qualidades heróicas e exemplares de uma pessoa justificam-lhe o exercício do poder (dominação carismática).

O fato é que se poderia expor inúmeros estudos e elementos que apontam para a legitimidade ou ilegitimidade do poder. Sternberger ${ }^{139}$, por exemplo, afasta a teoria de Weber para lecionar que o fenômeno de legitimação dos governos pode ter ou um fundamento civil, ou uma base religiosa. Assim, interessa notar que as formas de legitimação do poder indicadas não possuem uma preocupação direta com o conteúdo da legitimidade. Antes, aquilo que se entende por poder legítimo aflora no campo da investigação sociológica e histórica, apresentando como característica fatores diversificados, mas que acabam por justificar e reconhecer a titularidade do poder. Logo, consoante a adesão dos cidadãos à autoridade constituída, qualquer fator pode erigir-se como elemento de legitimação do poder.

Ainda, é preciso reforçar que os fatores de legitimação do poder estatal são distintos e por isso podem entrar em conflito. Sternberger ${ }^{140}$ adverte que a existência de uma pluralidade de padrões e fontes de legitimação pode desencadear um conflito de "legitimidades". O poder constituído estaria então continuamente ameaçado por novos padrões de legitimidade, dessa maneira, um governo que se afirmara como legítimo, pode ser rotulado como ilegítimo devido ao surgimento de um novo paradigma de justificação do poder. A observação feita por Sternberger torna complexa a tarefa de definir o conteúdo da legitimidade na medida em que aquilo que seja legítimo assume uma identidade mutável, conforme as mais diversas circunstâncias.

Nesse particular, o significado de legitimidade não pode ser dado pelo seu conteúdo, dado que variável, mas sim pela necessidade de justificar e ver reconhecido o

\footnotetext{
${ }^{138}$ WEBER, Max. Economia e Sociedade: fundamentos da Sociologia Compreensiva. V.1. $3^{\mathrm{a}}$ ed. Brasília: UNB, 1994. P. 144.

${ }^{139}$ STERNBERGER. Dolf. Typologie... p. 88.

${ }^{140}$ Ibid. p. 87.
} 
poder estatal. Portanto, conforme aponta Paulo Bonavides, a legitimidade "inquire acerca dos princípios fundamentais que justificam ou invalidam a existência do título e do exercício do poder." 141 Ou seja, a legitimidade simplesmente questiona, inquire e atesta acerca dos fundamentos da atribuição do poder. Ela, por si mesma, não confere reconhecimento e validade ao título e ao exercício do poder, pois não se chega a lhe cogitar um sentido material uniforme e definido.

No entanto, "legitimidade" é um termo equívoco, apresentando - como já se apontou - mais de um significado. Expôs-se, até o momento, o significado de legitimidade enquanto atributo do poder estatal; esse sentido vincula-se ao âmbito sócio-político na medida em que expressa a justificativa, com o assentimento dos governados, à titularidade do poder dos governantes.

Por outro lado, a legitimidade pode assumir um significado distinto e peculiar, correspondendo a uma noção de justiça. O foco, nesse caso, não é conferir salvo-conduto ou reconhecimento ao poderio estatal. Trata-se de compreender a legitimidade sob perspectiva axiológica, concebendo-a como critério de correção material do direito positivo.

Sobre o significado de legitimidade, aponta D'Entrèves ${ }^{142}$, que os juristas e os sociólogos percorrem caminhos distintos que dificilmente se cruzam. Os sociólogos - e, também, os cientistas políticos - encaram a legitimidade como um fenômeno político no qual a legitimação do poder é mera questão fática e prescinde, portanto, de um conteúdo ético preciso. Os juristas, de seu turno, buscam na legitimidade um sentido material que deve, obrigatoriamente, influenciar o direito positivo, orientando-o para a promoção da dignidade humana e do bem comum.

Essa busca por um conteúdo material da legitimidade acaba por estabelecer, no campo da ciência jurídica, a clássica dicotomia entre legalidade e legitimidade. Afirma D'Entrèves: "Legalidade e legitimidade cessam de se identificar no momento em que se admite que uma ordem pode ser legal, mas injusta." ${ }^{143} \mathrm{O}$ autor prossegue asseverando que o princípio da legalidade não se conforma tão somente com a correção formal das normas que compõem o sistema jurídico. Exige-se, de outro modo, uma adesão a certos valores

\footnotetext{
${ }^{141}$ BONAVIDES. Paulo. Ciência ... p. 124.

${ }^{142}$ D'ENTRÈVES, Alexandre Passerin. Légalité et Legitimité. p. 30. In: Annales de Philosophie Politique n.7: L’idée de Légitimité. Paris: Press Universitaires de France, 1967.

${ }^{143}$ Légalité et légitimité cessent de s'indentifier du moment où l'on admete qu'un ordre peut être legal mais injuste. Ibid. p. 38.
} 
tidos como essenciais para existência de uma sociedade livre e para garantia do desenvolvimento da personalidade humana. ${ }^{144}$

Arremata D’Entrèves:

"Esse valores são pedra de toque do direito, o aspecto substantivo da legalidade. Isso significa que legalidade e legitimidade se identificam novamente, mas de uma forma oposta àquela mencionada por Weber e defendida por certos positivistas. Lá a questão da legitimidade era uma questão de fato; aqui se trata de uma questão de justiça." 145

Nota-se, portanto, que a legitimidade coloca-se em oposição a uma legalidade meramente formal que se mostra despreocupada com a persecução do bem comum e, conseqüentemente, com a proteção da pessoa humana. Desse modo, a legalidade e a legitimidade só se confundem quando o direito positivo apresenta uma correção material intrínseca, ou seja, quando a lei é justa.

Nesse sentido, vale invocar uma decisão do Tribunal Constitucional Alemão recolhida na obra de Alexy. Em 1968, a Corte Constitucional germânica concluiu pela nulidade de um dispositivo da Lei de Cidadania do regime nazista que privava da nacionalidade alemã os judeus emigrados. Asseverou o Tribunal:

“ $O$ direito e a justiça não estão à disposição do legislador.

(...) Por conseguinte, o Tribunal Constitucional afirmou a possibilidade de negar aos dispositivos 'jurídicos' nacionalsocialistas sua validade como direito, uma vez que eles contrariam os princípios fundamentais da justiça de maneira tão evidente que o juiz que pretendesse aplicá-los ou

\footnotetext{
${ }^{144}$ Ibid. p.39 e 40.

145 D’ENTRÈVES, Alexandre Passerin. Légalité... p. 39. “Ces valeurs sont la pierre de touche du droit, l'aspect substantif de la légalité. Cela signifie que la légalité et la légitimité s'indentifient à nouveau, mais d'um façon opposée à celle dont parlait Weber et que prétendaient certains positivistes. Lá, la question de la légitimité était une question de fait; ici, c'est une question de justice."
} 
reconhecer seus efeitos estaria pronunciando a injustiça $e$ não o direito." 146

Conforme o entendimento da Corte alemã, a lei, desprovida de qualquer preocupação ética, é capaz de gerar a iniqüidade, logo, ela necessita coadunar-se com valores fundamentais que expressam o anseio humano pela justiça. Nesses termos, a legitimidade qualifica a lei, expressando a congruência entre lei e justiça.

A legitimidade configura-se, então, como parâmetro substancial de correção da legalidade, verificando em que medida a lei está adstrita à realização de valores que denotam o sentido de justiça. A lei considerada legítima é aquela amparada por preceitos axiológicos que limitam a atividade legislativa, pautando o ordenamento positivo pelos princípios fundamentais da justiça. Assim, a legitimidade presta-se a qualificar a lei como justa, podendo ser definida como a justiça a ser observada pelo direito positivo.

Os juristas pátrios reforçam, em certa medida, essa identificação entre legitimidade e justiça. Tal constatação encontra respaldo no magistério de Diogo Moreira Neto e Paulo Bonavides. O primeiro afirma que: "A substância da legitimidade, coincidimos com José Eduardo Faria, está na axiologia que suporta um sistema juspolítico." ${ }^{147}$. O segundo indica que: "a legitimidade tem exigências mais delicadas, visto que levanta o problema de fundo, questionando acerca da justificação e dos valores do poder legal." 148

Muito embora os autores nacionais citados não afirmem, explicitamente, que a legitimidade assume um significado de justiça, eles reconhecem nela uma carga axiológica que serve de amparo ou de correção ao ordenamento formalmente considerado. Ao se afirmar que a legitimidade levanta "o problema de fundo" do poder legal, ou, que ela é a axiologia que suporta o sistema juspolítico, quer-se dizer que o direito, sob a ótica formal, não evidencia, por si só, uma correção intrínseca.

Destarte, é possível concluir que a legitimidade, enquanto qualificativa da ordem legal, encampa um sentido de justiça, atribuindo correção material às normas que compõem o ordenamento. A legitimidade, sob esse aspecto, não é simplesmente uma

\footnotetext{
${ }^{146}$ ALEXY, Robert. $O$ conceito e validade do direito. Trad. Grecélia de Oliveira Mendes. São Paulo: Martins Fontes, 2009. p. 7.

${ }^{147}$ MOREIRA NETO, Diogo de Figueiredo. Legitimidade e Discricionariedade. $2^{\mathrm{a}}$ ed. Rio de Janeiro: Forense, 1991. p. 5.

${ }^{148}$ BONAVIDES. Paulo. Ciência... p.121.
} 
questão fática de conteúdo variável. Ao contrário, seu significado possui uma densidade precisa e pode ser definido como a justiça que informa o direito.

Em última análise, esse sentido de legitimidade representa uma crítica à concepção positivista do direito, pois a observância de critérios formais de validade jurídica não é suficiente para garantir uma adequada proteção ao desenvolvimento individual e social do ser humano.

\section{A NOÇÃO DE LEGITIMIDADE PRECONIZADA PELO ART. 70 DA CF DE 1988.}

O art. 70 da CF de 1988 apregoa que a atividade financeira do Estado deve ser contrastada em face da legitimidade. Nesse sentido, é preciso buscar o significado de "legitimidade" a que aduz o Texto Maior.

Como já se apontou, a legitimidade pode assumir um sentido de conteúdo variável, correspondendo apenas à justificação do título e do exercício do poder pelos governantes. De outra parte, a legitimidade, também, possui um significado material definível, aproximando-se da idéia de justiça que informa o ordenamento positivo.

No tocante ao significado da legitimidade inscrita no art. 70, a doutrina brasileira tem posições diversificadas. Cabe, desse modo, apresentar as teses existentes com o escopo de extrair o exato sentido e o alcance da legitimidade no âmbito da fiscalização financeira.

Celso Ribeiro Bastos constata, de início, que a expressão "legitimidade” é bem mais ampla que a mera legalidade, reconhecendo que: “Um ato pode ser legal, mas não ser legítimo, por estar em descompasso com valores fundamentais da coletividade". 149 A visão do autor aponta, sensivelmente, para uma compreensão axiológica da legitimidade concebendo-a, portanto, como aspecto de correção material do direito positivo.

${ }_{149}$ BASTOS, Celso Ribeiro. Curso de Direito Financeiro e Tributário. $7^{\mathrm{a}}$ ed. São Paulo: Saraiva, 1999. p. 91. 
De seu turno, Helio Mileski afirma expressamente que: "legitimidade tem, aproximadamente, o sentido de justiça, de racionalidade no exercício da atividade financeira." ${ }^{150}$ Para ele a legitimidade não se conformaria com o atendimento a lei, pois estrutura-se em fundamentos de moralidade, identificando-se com valores e princípios que atrelam a ação administrativa à consecução do interesse público. ${ }^{151}$

As lições de Ricardo Lobo Torres são semelhantes ao posicionamento de Mileski. Segundo Lobo Torres: “O aspecto da legitimidade, por conseguinte, engloba os princípios constitucionais orçamentários e financeiros, derivados da idéia de segurança jurídica ou de justiça." $152 \mathrm{O}$ autor, ao final, não deixa de concluir que "O controle da legitimidade, que é da própria moralidade, só agora se positivou na Constituição". ${ }^{153}$

Ressalte-se do magistério de Ricardo Lobo Torres o fato de que a noção de justiça expressa pela legitimidade está baseada em certos princípios constitucionais, em especial o da moralidade, expressamente positivados pela Constituição. Logo, a fiscalização quanto à legitimidade importaria, também, em um controle de constitucionalidade, na medida em que a atividade financeira do Estado seria confrontada com princípios constitucionais explícitos que, de seu turno, são derivados da idéia de justiça.

Régis de Oliveira, por sua vez, afasta qualquer concepção axiológica relativa ao significado de legitimidade. Segundo ele, a "legitimidade diz respeito não à obediência formal do preceito superior, mas ao real atendimento das necessidades públicas". ${ }^{154} \mathrm{~A}$ aferição da legitimidade para Régis está na conformidade da norma com as finalidades encampadas pelo ordenamento, ou seja, o autor propõe que a legitimidade condicione a atividade financeira do Estado à efetiva realização do interesse público. Ele reconhece que, filosoficamente, a legitimidade possui um sentido valorativo, mas afirma não ser esse o sentido que o constituinte atribuiu ao termo. ${ }^{155}$

Distanciando-se dos autores até o momento citados, está a doutrina de José de Ribamar Caldas Furtado. Este Conselheiro do TCE do Maranhão advoga que a legitimidade está afeita ao princípio democrático. Ressalta Furtado: “o controle da

\footnotetext{
${ }^{150}$ MILESKI, Hélio Saul. O Controle... p. 249

151 Idem.

152 TORRES, Ricardo Lobo. Tratado ... p. 508.

${ }^{153}$ Ibid. p. 509.

154 OLIVEIRA, Régis Fernandes. Curso ... p. 391.

155 "Filosoficamente, a legitimidade tem sentido axiológico, ou seja, apenas será legítimo aquilo que atende à natureza do homem. Teria aspecto crítico. Não é esse o sentido que a palavra foi empregada pelo legislador constituinte." Idem.
} 
legitimidade do gasto público é a fiscalização do atendimento da vontade popular"; e, “diz-se que uma despesa pública é legítima quando tem o apoio da opinião pública." 156 Essa tese apropria-se de um conceito de legitimidade meramente fático pelo qual a correção da atividade financeira se deduz do assentimento popular, e não da vinculação aos valores e princípios indicativos da idéia de justiça.

Fixam-se, assim, três posições distintas acerca do conceito de legitimidade preconizada pelo artigo 70 da CF de 1988. A primeira, capitaneada por Celso Bastos, Helio Mileski e Ricardo Lobo Torres, compreende a legitimidade sob o prisma dos valores, aproximando-a da idéia de moralidade e de justiça. A segunda corrente, a de Régis de Oliveira, confunde legitimidade com interesse público de modo que a conduta legítima não é aquela que observa a lei formal, mas a que atende, efetivamente, as necessidades públicas. Por fim, um terceiro entendimento afirma que a legitimidade liga-se à vontade democrática, ou seja, a atividade financeira legítima é aquela que se conforma com o anseio popular.

Data maxima venia, é preciso filiar-se à primeira posição, segundo a qual a legitimidade atrela-se a um senso de justiça. Isso porque, a concepção de legitimidade como vontade democrática ou como interesse público não é capaz de satisfazer ânsia pela correção material da atuação financeira do Estado.

Ora, a vontade popular - a história bem demonstra - nem sempre é capaz de compreender e decidir-se pelos caminhos do bem comum e da proteção da dignidade humana. De outro lado, o interesse público ou o reconhecimento das necessidades públicas não podem ser corretamente aferidos sem um critério axiológico que evidencie quais são as necessidades fundamentais da natureza humana.

Desse modo, a legitimidade deve ser identificada pelos valores e princípios que revelam o sentido de justiça, possibilitando que a sindicância das contas públicas supere o mero contraste formal entre atividade financeira do Estado e legalidade estrita. A fiscalização quanto à legitimidade dá condições para um exame mais substancial dos atos de disposição financeira, de modo que a análise formal de legalidade resta complementada por um controle de moralidade.

A legitimidade mede, assim, o aspecto ético da conduta administrativa com vistas a aferir a sua adequação material, logo, pode-se dizer, em síntese, que sindicar a

${ }^{156}$ FURTADO, José de Ribamar Caldas. O controle ... p. 7299. 
legitimidade das finanças públicas é verificar sua consonância com a moralidade. Nessa esteira aduz Julio Cesar de Araújo: "é pelo controle da legitimidade que se pode sindicar o atendimento ao princípio constitucional da moralidade." 157

Essa compreensão axiológica da legitimidade influi, também, na fiscalização quanto à legalidade e à economicidade. Reconhece Ricardo Lobo Torres que: “O controle da legitimidade é o que se exerce sobre a legalidade e a economicidade da execução financeira e orçamentária." 158

Ora, a legalidade, na sistemática constitucional, não pode ser reconhecida apenas como a lei formal que prescreve uma conduta determinada. Para tanto, o ordenamento positivo encampa, expressamente, preceitos normativos de elevada abstração e densidade valorativa: os princípios. Esses preceitos valorativos genéricos são corolários da idéia de justiça e sua positivação expressa reforça à compulsoriedade de sua observância pelos gestores públicos. Portanto, atividade financeira do Estado há de se submeter, também, a uma legalidade principiológica - em larga medida constitucionalmente qualificada - cujo objetivo precípuo é conferir correção material ao direito positivo, impedindo que a frieza da lei possa macular a personalidade humana e desviar a atuação do Estado da efetiva realização do bem comum.

No tocante à fiscalização da economicidade, a legitimidade preconiza um controle de eficiência da gestão financeira, pois em um cenário de recursos parcos nos quais as necessidades básicas do homem não são atendidas a contento, a aplicação racional e eficiente do dinheiro público é elemento imprescindível para apurar a correção ética dos gestores públicos. A legitimidade da gestão financeira em sua relação com a economicidade demanda, obrigatoriamente, o sucesso da relação custo-benefício e da produção máxima de resultados, pois não se admite uma atuação dispendiosa e inconseqüente que contribua para o desamparo das contingências fundamentais do ser humano.

Constata-se, portanto, que a fiscalização quanto à legitimidade afere a justiça na condução financeira do Estado, sendo que essa noção do justo é evidenciada pela adstrição da atividade financeira à moralidade, à legalidade e à economicidade. Logo, diante desse panorama, é preciso uma análise mais detida no sentido de melhor justificar a compreensão acerca da legitimidade consignada pelo art. 70 da CF de 1988.

\footnotetext{
157 ARAUJO, Julio Cesar Manhães de. Controle ... p. 271.

158 TORRES, Ricardo Lobo. Tratado ... p. 508.
} 


\subsection{Legitimidade e democracia.}

Não é demais ressaltar que a fiscalização das finanças públicas consignada pelo art. 70 deverá apurar tanto a legalidade como a legitimidade da atuação financeira do Estado. Com base nessa constatação, seria ilógico compreender a legitimidade exclusivamente como vontade democrática. Isso porque, no Estado Democrático de Direito - tal como plasmado pela Constituição de 1988 - a lei, melhor dizendo, a legalidade é fruto da atuação democrática. Logo, se a legitimidade correspondesse à vontade popular, a vinculação da atuação financeira do Estado à legalidade e à legitimidade seria, no mínimo, um pleonasmo, uma repetição desnecessária.

Já em 1789, o texto da Declaração dos Direitos do Homem e do Cidadão proclamava, solenemente, no art. $6^{\circ}$ : "A lei é a expressão da vontade geral." Notadamente, esse preceito prestigia os valores democráticos, pois com ele quer-se garantir que a lei não seja a decisão arbitrária de um indivíduo ou de uma classe de pessoas, mas que seja o reflexo do assentimento coletivo pelo qual os indivíduos - pareados pela igualdade decidem livremente pelo conteúdo da prescrição legal, submetendo-se de bom grado à ordem estabelecida.

Igualmente, a análise do regime democrático fundado pela CF de 1988 leva à conclusão de que a lei é fruto da vontade geral. Registre-se, antes de tudo, que na Democracia o povo goza da titularidade e do exercício do poder. Assim, o Estado democrático é aquele em que o povo obrigatoriamente toma parte no governo, decidindo sobre os desígnios últimos da atuação estatal. Nesse sentido, Manoel Gonçalves atesta que a democracia, em termos absolutos, "significa que todo povo deve participar do governo. Mais precisamente, que o povo há de tomar as decisões de governo. Assim, importa, em última análise, a identificação entre governantes e governados." 159

Reforça, na mesma linha, Friedrich Müller: “O termo 'democracia' não deriva apenas etimologicamente de 'povo'. Estados democráticos chamam-se governos 'do povo'; eles se justificam afirmando que em última análise o povo estaria governando." 160 Desse modo, não há que se falar em democracia se não se cogitar da participação do povo na esfera de governo.

\footnotetext{
${ }^{159}$ FERREIRA FILHO, Manoel Gonçalves. A Reconstrução da democracia. São Paulo:Saraiva, 1979. p. 25. ${ }^{160}$ MÜLLER, Friedrich. "Quem é o povo? A questão fundamental da democracia”. 4a ed. São Paulo: RT, 2009. p. 39.
} 
A CF de 1988 proclama no seu preâmbulo a intenção de instituir um Estado Democrático de Direito, bem como apregoa no parágrafo único do art. $1^{\circ}$ que: “Todo o poder emana do povo, que o exerce por meio de representantes eleitos ou diretamente, nos termos desta Constituição." O dispositivo constitucional confirma, portanto, a idéia de que no governo democrático o povo não só é o titular do poder, como também o exerce. Contudo, o exercício do poder popular pode ser direto, ou por meio de representantes, sendo, ainda, que as formas desse exercício são reguladas pela Constituição Federal. ${ }^{161}$

Desse modo, a conformação constitucional do exercício do governo pelo povo depende de determinados mecanismos institucionais que permitem a interferência e a participação do povo na condução do interesse geral. Essa participação pode se configurar de modo direto e pessoal, ou por meio de representantes eleitos.

No tocante à gênese legislativa, é preciso reconhecer que a participação popular se dá, basicamente, pela via representativa. Ainda que haja a previsão de métodos de participação democrática direta como a iniciativa popular de projeto de lei, o plebiscito e o referendo, a aprovação definitiva das leis é uma tarefa confiada de modo exclusivo ao Poder Legislativo.

Ora, a iniciativa popular de lei apenas leva à Casa Legislativa uma proposta, um projeto de lei. Ao fim e ao cabo, é sempre o Parlamento quem decide pela aprovação da lei, determinando, assim, o conteúdo do comando normativo. Por sua vez, os institutos do referendo e do plebiscito ficam a depender sempre da iniciativa do Legislativo. Nesses institutos, embora o povo seja chamado a se pronunciar de modo direto sobre determinada lei ou questão política, o Parlamento assume uma posição fundamental, pois cabe a ele, exclusivamente, autorizar o referendo e convocar o plebiscito (art. 49, XV, da CF).

Bem leciona José Afonso da Silva que a iniciativa popular, o referendo e plebiscito não são institutos de democracia direta, mas sim de democracia semidireta. In verbis:

"As primeiras manifestações de democracia participativa consistiram nos institutos de democracia 'semidireta', que

\footnotetext{
161 Aponta Manoel Gonçalves: "Ninguém contestará, hoje, ser a democracia o princípio de atribuição do poder adotado pelo constitucionalismo. Na verdade, vigora atualmente a crença numa simbiose entre constitucionalismo e democracia, democracia e constitucionalismo." FERREIRA FILHO, Manoel Gonçalves. Princípios... p. 43.
} 


combinam instituições de participação direta com
instituições de participação indireta, tais como: - a
'iniciativa popular' (...); - o 'referendo popular' (...); - o
'plebiscito' (...); - a 'ação popular'(...).", 162

Portanto, ao menos no que se refere à lei, a participação democrática é concretizada por meio da representação política. Manoel Gonçalves esclarece que a identificação de democracia como governo representativo é atribuída à doutrina de John Stuart Mill. ${ }^{163}$ A idéia de representação política como mecanismo de expressão democrática parte da imperiosa constatação de que é extremamente difícil, senão impossível, promover o debate e colher as opiniões e o assentimento de cada cidadão sobre todas as questões relativas ao governo. ${ }^{164}$

Ademais, fatores como a dimensão do território em que se funda o Estado, a quantidade de indivíduos opinantes e a complexidade das questões postas ao seu exame contribuem para reforçar o desprestígio de uma democracia baseada exclusivamente na participação direta dos cidadãos. Nesses termos, ganha cada vez mais relevo as lições de Stuart Mill, que já no século XIX advertia:

"Porém, uma vez que é impossível, em uma comunidade
maior do que uma única cidade, que todos participem
pessoalmente de todos os negócios públicos, a não ser de
muito poucos, conclui-se que o tipo ideal de governo perfeito
deve ser o representativo." 165

Logo, a democracia não se consubstancia tão somente como a participação direta do povo no governo, uma vez que tal intento seria instrumentalmente impossível. A

\footnotetext{
${ }^{162}$ SILVA, José Afonso. Curso... p. 141 e 142.

${ }^{163}$ FERREIRA FILHO, Manoel Gonçalves. Princípios... p. 45.

${ }^{164}$ Atesta Bobbio: "É evidente que, se por democracia direta se entende literalmente a participação de todos os cidadãos em todas as decisões a eles pertinentes, a proposta é insensata. Que todos decidam sobre tudo em sociedades sempre mais complexas como são as modernas sociedades industriais é algo materialmente impossível." BOBBIO, Norberto. O Futuro da Democracia: uma defesa das regras do jogo. $6^{\mathrm{a}}$ ed. Rio de Janeiro: Paz e Terra. p. 42.

${ }^{165}$ MILL. John Stuart. Considerações sobre o governo representativo. Trad. Débora Ginza e Rita de Cássia Gondim. São Paulo: Editora Escala, 2006. p. 65.
} 
democracia importa, também, na representação política pela qual os cidadãos elegem seus representantes, autorizando-lhes a expressar a vontade daqueles que os escolheram.

Portanto, concebe-se nas democracias hodiernas regras e procedimentos sobre a escolha daqueles que podem tomar decisões em nome da coletividade. Bem assevera Bobbio que uma definição mínima de democracia deve "considerá-la caracterizada por um conjunto de regras (primárias ou fundamentais) que estabelece 'quem' está autorizado a tomar decisões coletivas e com quais 'procedimentos'. ${ }^{166}$ Segue ele, afirmando que:

"Por isso, para que uma decisão tomada por indivíduos (um, poucos, muitos, todos) possa ser aceita como decisão coletiva é preciso que seja tomada com base em regras (não importa se escritas ou consuetudinárias) que estabeleçam quais são os indivíduos autorizados a tomar as decisões vinculatórias para todos os membros do grupo, e à base de quais procedimentos." 167

Nesse diapasão, a CF de 1988 prevê um sistema eleitoral que, aliado ao reconhecimento de direitos políticos aos cidadãos, configura um procedimento de escolha de representantes, autorizando-os a tomar decisões em nome da coletividade. Vale ressaltar que o sistema eleitoral previsto na Constituição tem por premissa o sufrágio universal por meio do voto direto, secreto e periódico, conferindo, assim, garantias mínimas para que o povo possa escolher adequadamente seus representantes.

De outra parte, é preciso reconhecer que a democracia efetivada pela representação política não se resume à escolha de representantes. Ao contrário, as eleições ultrapassam a mera função designatória na medida em que representa uma adesão a determinada política governamental encampada pelo candidato eleito. Portanto, nas democracias representativas a eleição é o meio fundamental pelo qual o povo participa da formação da vontade do governo e no processo político. ${ }^{168}$

$\mathrm{Na}$ ordem jurídica brasileira constata-se que os membros do Parlamento e o Chefe do Executivo são eleitos pelo povo. Nesse sentido, se, como exposto, cabe ao

\footnotetext{
${ }^{166}$ BOBBIO, Norberto. O Futuro... p. 18.

${ }^{167}$ Idem.

${ }^{168}$ SILVA, José Afonso. Curso... p. 138.
} 
Legislativo a decisão definitiva sobre a gênese lei, é imperioso concluir que ela é a expressão da vontade geral. A lei, nas democracias representativas, conta com assentimento dos representantes eleitos pelo povo, adquirindo uma importância e um significado particular no Estado Democrático. Aduz Garcia de Enterría: “A representação política é o instrumento para a formação da vontade geral e esta se expressa somente na Lei, com seus atributos de superioridade e imperatividade;" 169

Portanto, a lei no Estado Democrático de Direito tem uma legitimidade democrática inerente, pois ela é concebida por representantes escolhidos pelo povo em um sistema que os autoriza a decidir pelo coletivo.

Logo, seria ilógico contrastar a atividade financeira do Estado em face da legalidade e da legitimidade, se a legitimidade fosse considerada apenas como a vontade democrática. Ora, nesse caso, para verificar o atendimento da vontade do povo bastaria um controle de legalidade, porque a lei é corolário da vontade geral.

Ainda mais no âmbito das finanças públicas em que toda atividade atrelada à arrecadação de receitas e à realização de despesas é veiculada por meio de lei. A CF de 1988 é expressa ao consignar que as peças orçamentárias se consubstanciam em leis. Ressalta o art. 166 que: “Os projetos de lei relativos ao plano plurianual, às diretrizes orçamentárias, ao orçamento anual e aos créditos adicionais serão apreciados pelas duas Casas do Congresso Nacional, na forma do regimento comum."

O orçamento é o principal espelho da atividade financeira do Estado, nele está personificado todo um programa, um plano de ação governamental. ${ }^{170}$ Assim, submeter a peça orçamentária à apreciação e à aprovação do Legislativo - sendo que este pode até alterá-la - consiste, fundamentalmente, em atribuir um crivo democrático à atividade financeira do Estado, pois os parlamentares, insista-se nisso, são representantes escolhidos pelo povo.

Vem à baila a doutrina de Alvaro Rodriguez Bereijo, que ao prefaciar a obra de Laband atesta:

\footnotetext{
169 “La representación política es el instrumento para la formulación de la voluntad general y ésta se expresa sólo en la Ley; cons sus notas de superioridad e irresistibilidad;" ENTERRÍA, Eduardo García de. Democracia, Jueces y Control de la administración. 5 $5^{\mathrm{a}}$ ed. ampl. Navarra: Thomson Civitas, 2005. p. 68.

${ }^{170}$ SILVA, José Afonso da. Orçamento-programa no Brasil. São Paulo:RT, 1973. p. 1 a 3.
} 
"Ele (Laband) conferiu ao Orçamento um aspecto jurídicopolítico ou constitucional inegável, resultado de uma grande revolução política, que constitui a origem dos modernos sistemas políticos liberais democráticos, enquanto representa a autorização da comunidade política através de seus representantes, que mediante a aprovação da Lei de Orçamento prestam seu consentimento ao programa de receitas e gastos públicos do Governo para um período de tempo determinado." 171

O excerto reforça a tese de que a aprovação da lei de orçamento pelo Parlamento é fator contundente para dotá-la de respaldo democrático de modo que a sindicância da legalidade da atuação financeira do Estado abarca, também, uma análise sobre o fundamento democrático da peça orçamentária.

Portanto, seria desnecessário sindicar as finanças públicas em face da legalidade e da legitimidade, se esta correspondesse à vontade democrática, pois a lei, no Estado Democrático, é expressão da participação do povo.

Entretanto, o que foi até aqui exposto não está imune à crítica. Poderia se aludir que os representantes do povo, quando da apreciação e aprovação do orçamento, se afastaram do verdadeiro anseio popular, consignando por meio da lei orçamentária uma atuação financeira que se afasta da realização do interesse público. Nesse contexto, seria possível afirmar que a apuração da legitimidade verifica o verdadeiro atendimento da vontade popular, corrigindo, assim, os eventuais vícios da representação política.

Para responder a essa crítica, afastando a tese de que a legitimidade da atuação financeira confunde-se com vontade popular é preciso concluir que o real interesse público, o bem comum, nem sempre se confunde com a vontade do povo, ainda que apurada de modo direto.

\footnotetext{
${ }^{171}$ BEREIJO, Alvaro Rodriguez. Estudio... p. XI. "Ello (Laband) ha dado al Presupuesto un aspecto jurídico-político o constitucional innegable, resultado de una gran revolución política, que constituye el origen de los modernos sistemas políticos liberales democráticos, por quanto representa la autorización de la comunidad política através de sus representantes, que mediante de la aprobación de la Ley del Presupuesto prestan su consentimiento al programa de ingressos y de gastos públicos del Gobierno para un período de tiempo determinado."
} 
Evidentemente não se está aqui a advogar pela inutilidade da democracia, no entanto, aquilo que seja a legitimidade da atuação financeira do Estado não pode ser inferida apenas sob a perspectiva da vontade popular. A democracia - juntamente com o arranjo institucional que dela decorre - tem sua relevância como método racional para se chegar a uma decisão política, mas a democracia, por si só, não é um método seguro para dizer o que é bom ou mau, nem o que é certo ou errado.

São elucidativas as lições de Joseph Alois Schumpeter:

"A democracia é um método político, isto é, um certo tipo de arranjo institucional para se chegar a uma decisão política (legislativa ou administrativa) e, por isso mesmo, incapaz de ser um fim em si mesmo. (...) A democracia, como qualquer outro método, não produz sempre os mesmos resultados nem favorece sempre os mesmos interesses ou ideais. A lealdade racional à democracia, por isso mesmo, pressupõe não apenas um esquema de valores hiper-racionais, mas também certas condições da sociedade na qual a democracia pode operar de maneira que nos agrade." 172

É de se constatar que o povo, do qual se extrai a vontade democrática, nem sempre possui condições necessárias para expressar uma opinião consciente e racional, bem como a decisão popular pode se afastar de critérios axiológicos - de valores hiperracionais como quer Joseph Schumpeter - que prestigiam a dignidade da pessoa humana e a concretização da justiça.

A vontade popular é, no mais das vezes, instável e sujeita às mais variadas formas de manipulação. A pena de William Shakespeare captou a inconstância e a vulnerabilidade da vontade popular, imortalizando-a na peça Julio César. O dramaturgo inglês demonstra a instabilidade dos anseios do povo, tendo como cenário a morte de César. Na peça, os discursos inflamados de Bruto e Marco Antonio influenciam facilmente

172 SCHUMPETER, Joseph Alois. Capitalismo, socialismo e democracia. Trad. Ruy Jungmann. Rio de Janeiro: Ed. Fundo de Cultura, 1961. p. 295 e 296. 
a atitude dos cidadãos romanos que ora apoiavam a Bruto, assassino de César, ora exaltavam a Marco Antônio, defensor de César. ${ }^{173}$

A história, de seu turno, é cheia de exemplos que atestam os equívocos do assentimento democrático. O chamado "Bonapartismo" talvez seja o exemplo mais eloqüente. Napoleão Bonaparte tomou de assalto o poder na França e consagrou-se imperador de forma plebiscitária, servindo de exemplo universal a muitos déspotas que, após a usurpação violenta do poder, usam do expediente do plebiscito para justificarem o título e o exercício do poder. ${ }^{174}$

Outrossim, vale lembrar que ideologias totalitárias como nazismo e o fascismo lograram encontrar forte respaldo popular, tanto é que seus líderes ascenderam ao poder por meio do voto. Dessa maneira, um regime jurídico preocupado com a promoção e a preservação da dignidade humana não pode se fiar apenas na vontade democrática.

As Constituições parecem reconhecer os perigos da vontade democrática e estabelecem um corpo de normas e princípios intangíveis, colocando-os a salvo do assentimento do povo e do legislador constitucional ou infraconstitucional. Fala-se na doutrina pátria em cláusulas pétreas que encampam direitos fundamentais e princípios basilares à conformação de uma ordem jurídica justa. Mas seja qual for o nome que se dê a esse conjunto de dispositivos constitucionais é imperioso reconhecer que a ordem jurídica constitucional reconhece direitos fundamentais e outras garantias individuais cujo conteúdo não está à disposição da opinião majoritária, ou mesmo unânime.

Stephen Holmes ${ }^{175}$ aponta que o constitucionalismo, sob certa perspectiva, é antidemocrático. Segundo ele, a função básica da Constituição é remover algumas decisões do processo democrático, pois há direitos fundamentais e outros valores que não decorrem do consenso, excluindo o reconhecimento desses axiomas do alvedrio subjetivo dos cidadãos.

Entretanto, Dworkin ${ }^{176}$ demonstra com precisão que a verdadeira democracia não apenas admite, como também pressupõe a salvaguarda de posições contramajoritárias,

\footnotetext{
${ }^{173}$ Cf. SHAKESPEARE, William. Júlio César. Ato III. Cena II. Trad. Carlos Lacerda. $2^{\mathrm{a}}$ ed. Rio de Janeiro: Bibliex, 1992.

${ }^{174}$ É consagrada na doutrina constitucional a fórmula "constituição cesarista ou bonapartista" que qualifica a constituição outorgada de forma autoritária e sobre a qual se reclama um plebiscito posterior para lhe dotar de uma legitimidade meramente sociológica.

${ }^{175}$ HOLMES, Stephen. Precommitment and the paradox of democracy. In: ELSTER, Jon; SLAGSTAD, Rune. Constitutionalism and Democracy. Cambridge: Cambridge University Press, 1998. p. 190.

${ }^{176}$ DWORKIN, Ronald. Equality, democracy, and constitution: we the people in Court. Alberta Law Review, n. 28, p. 324/346, 1990.
} 
cujo reconhecimento advém não do assentimento popular, mas da exigência transcendental de princípios decorrentes da moralidade política. Estes princípios estão - em geral erigidos constitucionalmente e limitam a participação democrática. Assevera o autor, que todo agente estatal jura lealdade à Constituição e, portanto, tem a obrigação de desafiar a vontade popular quando estão em jogo as garantias constitucionais. ${ }^{177}$

Isso porque o sistema jurídico reconhece e encampa disposições axiológicas centradas na dignidade da pessoa humana. Bem anota Gustavo Binenbojm que: “ $\grave{A}$ centralidade moral da dignidade do homem, no plano dos valores, corresponde a centralidade jurídica dos direitos fundamentais, no plano do sistema normativo." 178

Logo, resta consignar que os critérios axiológicos que levam ao reconhecimento positivo de direitos fundamentais limitam a atuação democrática justamente porque a vontade popular nem sempre se coaduna com axiomas derivados da idéia de justiça. Em outras palavras, as decisões democráticas nem sempre se preocupam com uma correção de índole material a ser aferida com base naquilo que é moral ou justo.

Desse modo, a legitimidade da atuação financeira do Estado não repousa no assentimento da vontade popular, ainda que apurado de modo direto. A previsão de que a fiscalização financeira levará em conta tanto a legalidade como legitimidade conduz à conclusão de que o controle de legitimidade requer uma análise mais substancial da atividade financeira do Estado. O controle da legitimidade indaga sobre a correção material das finanças públicas, verificando sua adstrição a critérios valorativos que conferem o qualificativo de justo ao ordenamento.

Portanto, a legitimidade das finanças públicas relaciona-se com a observância de princípios derivados da idéia de justiça, possuindo um reclame axiológico notório que não pode ser evidenciado, ao menos de maneira exclusiva, pela via democrática.

Do contrário, o orçamento participativo seria padrão indispensável para a legitimidade da atuação financeira do Estado. Entretanto, nota-se que o orçamento participativo é uma experiência vivenciada apenas em alguns municípios brasileiros e não

\footnotetext{
177 "Every official swears loyalty to the constitution, and therefore has a responsibility to defy popular will when the constitution's guarantees are in play." Ibid. p. 325.

178 BINENBOJM, Gustavo. Uma Teoria do Direito Administrativo: Direitos fundamentais, Democracia e Constitucionalização. $2^{\mathrm{a}}$ ed. Rio de Janeiro: Renovar, 2008. p. 50.
} 
conta com um regime legal uniforme e definido; ele visa apenas conferir alguma participação popular na condução das finanças públicas. ${ }^{179}$

Não cabe aqui discutir sobre a conveniência ou não da adoção do chamado orçamento participativo. Quer-se apenas ressaltar que se a vontade popular, aferida diretamente, fosse critério de legitimidade da atuação financeira do Estado, o orçamento participativo deveria ser de adoção compulsória em todos os âmbitos da Federação. O que, evidentemente, não ocorre na prática, pois não há mandamento constitucional expresso que obrigue a adoção do orçamento participativo. Muito menos há a confiança de que aquilo que foi consignado pela participação popular corresponde a efetiva satisfação das necessidades públicas.

Régis de Oliveira, ao tratar da vinculação dos governantes às propostas orçamentárias deliberadas pelo povo, reconhece: “Evidente está que muitas sugestões são inviáveis; outras, sem importância. No entanto, aquilo que for captado como real necessidade não pode ser desprezado pelo governante". ${ }^{180}$

Confere-se, mais uma vez, que a vontade democrática aferida diretamente nem sempre volta-se à satisfação do interesse coletivo e ao prestígio dos direitos fundamentais. Conforme aduz Régis de Oliveira, caberia aos governantes cotejar os anseios do povo apurados por meio de propostas orçamentária diretas, verificando em que medida eles se coadunam com o bem comum.

Assim, não há que se atrelar a legitimidade da atuação financeira à vontade popular. Aquilo que seja o controle da legitimidade está relacionado ao contraste das finanças públicas com a efetiva realização da justiça. Certamente, a vontade popular não é fator seguro para garantir a correção material da atividade financeira do Estado, uma vez que o assentimento democrático está sujeito a inúmeras variáveis de modo a dificultar que a vontade do povo se determine, definitivamente, em favor do bem comum e da dignidade da pessoa humana.

\footnotetext{
179 Cf. CONTI, José Maurício. Direito Financeiro... p. 84 e 85 e SOUZA, Celina. Construção e consolidação de instituições democráticas: papel do orçamento participativo. In: São Paulo Perspectiva, São Paulo, v. 15, n. 4, dez. 2001. <http://www.scielo.br/scielo.php?script=sci_arttext\&pid=S010288392001000400010\&lng=pt\&nrm=iso >. Acesso em: 22. 06.2011.

${ }^{180}$ OLIVEIRA, Régis Fernandes. Curso ..., p. 360.
} 


\subsection{Legitimidade e interesse público.}

Certamente, a correção material da atuação financeira do Estado resta evidenciada quando esta logra realizar o interesse público. Em outros termos, a atividade financeira do Estado só se reputa escorreita, hígida e, portanto, legítima se atender aos reclames individuais e coletivos. ${ }^{181}$

Dessa forma, a noção de legitimidade preconizada pelo art. 70, caput, da CF de 1988 acaba se confundindo com a exigência de satisfação do interesse público. Note que, ao aferir a legitimidade das finanças públicas, os controles, interno e externo, verificam a aderência da atividade financeira do Estado à realização das necessidades coletivas, do bem estar geral, das fidedignas aspirações individuais, em suma, se os gestores públicos atentaram para a efetiva consecução do bem comum.

Assim, um expediente para revelar a noção de legitimidade apregoada pelo art. 70 da CF seria o de atrelá-la ao conceito de interesse público. Todavia, esse expediente não se mostra muito seguro, pois tal qual a legitimidade, a noção de interesse público é das mais tormentosas. Ou seja, definir, simplesmente, a legitimidade como o atendimento das necessidades públicas consiste em mudar o enfoque da compreensão: se antes era necessário analisar o significado de legitimidade, agora será preciso fixar a exata noção do conceito de interesse público que, de seu turno, mostra-se por demais vago.

Ocorre que o conceito de interesse público é um dos mais heterogêneos do direito público. A heterogeneidade não se refere, nesse particular, ao campo da significação do conceito, mas da constatação prática daquilo que pode ser encampado sob o título de interesse público. Confira, por exemplo, que a necessidade de preservação da propriedade privada, a extinção de desigualdades, a efetivação da saúde pública, a liberdade de imprensa, dentre outros reclames, figuram certamente como pretensões sociais a serem perseguidas pelo poder estatal.

Odete Medauar ${ }^{182}$ observa, então, que a complexidade social fez surgir uma multiplicidade de aspirações individuais e coletivas que podem, a seu modo, serem

\footnotetext{
${ }^{181}$ Como bem aponta Diogo Figueiredo o interesse público é, sim, padrão de legitimidade. Ele explica que os órgãos de expressão do Estado - Legislativo, Executivo e Judiciário - visam, indiscutivelmente, ao interesse público. Assim, "o interesse público, antes ou depois de legislado, é sempre padrão de legitimidade."

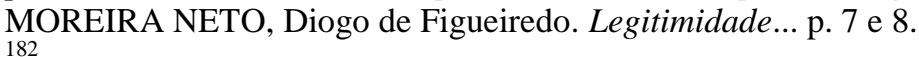


qualificadas como interesse público o que, sem dúvida, não deixa de evidenciar alguma problemática quanto à sua definição concreta. Diz ela que:

"A uma concepção de homogeneidade do interesse público segue-se uma situação de heterogeneidade; de uma idéia de unicidade passou-se à concreta existência de multiplicidade de interesses públicos. A doutrina menos antiga refere-se à impossibilidade de rigidez na prefixação do interesse público, sobretudo pela relatividade de todo o padrão de comparação. Menciona-se a indeterminação e dificuldade de definição do interesse público, a sua difícil e incerta avaliação e hierarquização, o que gera crise na sua própria objetividade."183

De fato, a constatação apontada pela citada autora é procedente. Os mais variados reclames que podem alçar à categoria de interesse público a ser considerado pelo Estado não torna simples a sua definição prática. Há, sem dúvida, uma dificuldade em extrair o interesse público de determinados casos. Não só porque as pretensões são múltiplas, mas, sobretudo porque são todas válidas e se apresentam, não poucas vezes, de modo conflitante. Assim, a fixação do interesse público passa, como afirma Odete Medauar, por critérios de avaliação e de hierarquização que permitem precisar o exato conteúdo do interesse a ser perseguido pelo Estado.

Dessa maneira, pode-se dizer, por certo, que a atuação financeira legítima é a aquela que realiza as pretensões públicas, todavia, tal sentença não define de modo preciso, pronto e acabado o questionamento sobre o que seria a atuação legítima. Existiria, apenas, uma mudança de foco, pois se é possível indagar sobre o conteúdo da legitimidade, é igualmente possível, outrossim, inquirir sobre a exata definição daquilo que seja um anseio válido e, por isso, apto a ser atendido pelo Poder Público.

Na verdade, a fixação do interesse público torna imprescindível um embate axiológico no qual os valores presentes na discussão indicarão o reconhecimento, as prioridades e a hierarquia das pretensões sociais e individuais a serem encampadas pelo

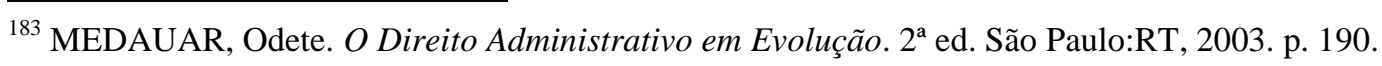


Estado. Nesse sentido, a comprovação do atendimento das necessidades humanas pela atividade financeira do Estado, que imprimiria a esta função estatal o qualificativo da legitimidade, não dispensa um juízo valorativo sobre o que é realmente, no caso específico, o interesse público.

$\mathrm{Na}$ atualidade, a própria noção de interesse público está a depender de um respaldo axiológico mais fundamentado, pois se encontra em xeque a tradicional concepção de supremacia do interesse público sobre privado. Não se cogita mais que a definição do interesse público possa emanar da dicotomia, por tanto tempo propagada, entre pretensões públicas versus pretensões privadas, muito menos que o arbítrio do administrador decida qual contingência humana deve ser acolhida pelo Estado. Antes, aquilo que seja o interesse público passa por juízos de ponderação entre os direitos fundamentais e outros valores metaindividuais constitucionalmente consagrados. Aponta Gustavo Binenbojm:

"a definição do interesse público e de sua propalada supremacia sobre o interesse particular, deixa de estar ao inteiro arbítrio do administrador, passando a depender de juízos de ponderação proporcional entre os direitos fundamentais e outros valores e interesses metaindividuais constitucionalmente consagrados." 184

Nota-se, inicialmente, que o autor a pouco citado não nega a existência do chamado interesse público, mas evidencia que a sua correta definição não pode comportar uma prevalência necessária sobre os interesses dos particulares. No decorrer das suas lições ele chama a atenção para o fato de que os valores constitucionais tutelam tanto as aspirações privadas como as coletivas de modo que o interesse público pode residir tanto no prestígio ao interesse individual como na implementação do interesse coletivo. ${ }^{185}$

Segundo ele, mesmo nos casos em que se coloca um claro confronto entre interesses difusos e privados, o administrador deve valer-se de um raciocínio de

${ }^{184}$ BINENBOJM, Gustavo. Da Supremacia do Interesse Público ao Dever de Proporcionalidade: um novo paradigma para o Direito Administrativo. In: SARMENTO, Daniel (org.). Interesses Públicos versus Interesses Privados: desconstruindo o princípio da supremacia do Interesse público. Rio de Janeiro: Lumen Juris, 2007. p. 128.

${ }^{185}$ Ibid. 148. 
ponderação em que serão cotejados, obrigatoriamente, os interesses individuais constitucionalmente protegidos e outros valores constitucionais concorrentes, sendo a solução satisfatória para o caso aquela que realize ao máximo as duas pretensões. ${ }^{186}$

Mas o que se quer demonstrar, a partir das lições de Gustavo Binenbojm, é que a definição daquilo que seja o interesse público não escapa a um juízo axiológico. A própria configuração do interesse público está sujeita à observância de valores caros à sociedade e que, por isso mesmo, figuram na Lei Maior. O interesse público não é, assim, uma locução vaga cujo conteúdo está ao arbítrio do administrador. Antes, o verdadeiro interesse público só encontra fundamento e justificativa quando se coaduna com a axiologia presente no sistema jus-político.

Na visão de José Eduardo Faria, a idéia de interesse público cumpre exatamente a função de "princípio totalizador dos interesses tutelados pelo direito" "187, servindo de amparo lógico aos valores em confronto, ao mesmo tempo em que opera a soma dos valores emanados pela sociedade. Diz o autor: "Em outras palavras, o interesse público tem acima de tudo uma função pragmática. Trata-se de um conceito que permite ao direito filtrar os diferentes valores em confronto na vida social, alcançando uma idéia de fechamento de acabamento lógico daqueles valores majoritariamente reclamados por parte da sociedade." 188

Assim, a noção de interesse público não expressa um valor unívoco, mas uma somatória deles, servindo, na espécie, como elemento integrador da axiologia dos valores existentes no campo social. Essa característica de acabamento lógico e de elemento totalizador de valores que está inserta na carga semântica da locução "interesse público" acaba por conferir ao vocábulo um sentido de vinculação àquilo que bom, permitindo acolher na esfera de sua significação uma ampla gama de valores fundamentais para a sociedade. ${ }^{189}$

Desse modo, quando se advoga que o Estado deve realizar o interesse público, apregoa-se, em realidade, uma vinculação genérica à correção material, à consecução da justiça e à promoção do bem comum. Nessa ótica tanto o interesse público, como a

\footnotetext{
${ }^{186}$ Ibid. 150 a 151.

${ }^{187}$ FARIA, José Eduardo. A definição do interesse público. In: SALLES, Carlos Alberto (org.). Processo Civil e Interesse Público. São Paulo: RT, 2003. p. 79.

${ }^{188}$ Idem.

189 "Ele (o legislador) se vale da idéia de interesse público, de bem comum, de uma série de palavras que, apesar de ambíguas, despertam um sentido de lealdade, de apoio, conseguem funcionar como um mecanismo de catalisação de uma obediência espontânea por parte da sociedade.” Ibid. p. 80.
} 
legitimidade possuem, genericamente, significado semelhante, na medida em que ambos exigem uma atuação materialmente hígida, superando a mera concordância com aspectos formais de correção.

Entretanto, a constatação prática do atendimento ao interesse público em situações específicas reclama, evidentemente, uma análise axiológica do caso concreto. Constatar que o interesse público foi auferido em uma situação isolada comporta em investigar se o fato em tela se mostrava consentâneo com valores que denotam o sentido de justiça. Assim, buscar a noção de legitimidade no conceito de interesse público não se mostraria muito profícuo, pois ambos desembocam na necessidade de precisar, sob o prisma axiológico, a correção intrínseca de determinada conduta.

Portanto, muito embora o interesse público possa ser aferido, genericamente, como padrão de legitimidade, é bem verdade que ambos os conceitos dependem de investigações valorativas sobre os fatos que pretendem qualificar. A atuação do Estado, seja ela legítima ou comprometida com o atendimento das necessidades públicas, só pode ser assim definida porque há uma justificativa axiológica que fundamenta a sua correção material. Logo, a constatação da legitimidade e, também, da satisfação do interesse público pela atividade financeira do Estado fica na dependência de critérios valorativos que devem ensejar um juízo positivo de correção.

Por fim, se atuação financeira legítima busca realizar o interesse público, a aferição da legitimidade não escapa, outrossim, a uma compreensão axiológica que é necessária, até mesmo, para definir aquilo que seja o interesse público.

\subsection{Legitimidade e Moralidade.}

Não é demais repetir que parte da doutrina do direito financeiro relaciona a legitimidade com a moralidade. Mais precisamente, eles entendem que o controle da legitimidade expresso no art. 70, caput, da CF representa, na verdade, um controle de moralidade dos atos de gestão financeira. Confira, por exemplo, a doutrina de Ricardo Lobo Torres: "O controle da legitimidade, que é da própria moralidade, só agora se 
positivou na constituição, mas já era reclamado há muito pelos juristas brasileiros. ${ }^{" 190} \mathrm{Na}$ mesma linha apregoa Helio Saul Mileski:

"Legitimidade seria então estar conforme a lei e ao Direito. Contudo, deixa de encerrar apenas uma conformação de natureza legislativa, indo mais além, na medida em que se estrutura em fundamentos de moralidade, identificando-se com os valores, os princípios e fins que regem a ação administrativa, na consecução dos objetivos estatais - o interesse público."

O entendimento dos autores citados evidencia que a noção de que a legitimidade ultrapassa a de legalidade positiva, buscando exigir, também, a correção ética dos responsáveis pela condução da atividade financeira do Estado. Para tanto, Helio Mileski e Ricardo Lobo Torres socorrem-se da moralidade, ou seja, apregoam que a atuação legítima dos gestores, além de legal, deve ser, outrossim, moral.

Destarte, para melhor compreender a noção de legitimidade exposta pelo art. 70, é preciso enveredar, ainda que de modo breve, pela Filosofia do Direito no intuito de bem compreender as relações entre Moral e Direito.

Registre-se, inicialmente, que há uma distinção clara entre Moral e Direito. Conforme as preleções de Michel Villey ${ }^{192}$, a Moral é uma arte que se preocupa com a virtude subjetiva do individuo, prescrevendo-lhe condutas justas. O Direito, por seu turno, não vigia a virtude dos indivíduos, nem lhes regula diretamente a conduta, mas distribui, segundo a justiça, o que pertence a cada um. O Direito é, nas lições do autor, relacional, compondo o fenômeno social na medida em que tutela o bem do outro.

De fato, a virtude individual e interna do indivíduo não é, necessariamente, considerada pela ordem jurídica. Por exemplo, a temperança ou a glutosidade de alguém em relação à alimentação é indiferente para o Direito, mas não o é para o âmbito das regras morais. Nesse sentido, o Direito volta-se, fundamentalmente, para regular o seio social,

\footnotetext{
190 TORRES, Ricardo Lobo. Tratado... p. 508.

${ }^{191}$ MILESKI, Hélio Saul. O Controle... p. 241.

192 VILLEY, Michel. Filosofia do Direito: definições e fins do direito, os meios do direito. Trad. Márcia Martinez de Aguiar. São Paulo:Martins Fontes, 2003. p.72 a 75.
} 
precisando o que compete a cada um no intuito de promover a pacificação social; enquanto que a Moral fica relacionada à esfera interna dos indivíduos singularmente considerados, ditando-lhes condutas intrinsecamente boas.

Todavia, é preciso esclarecer que o Direito não é indiferente à Moral. Embora possam ser concebidos de modo apartado, Direito e Moral não são realidades autoexcludentes. ${ }^{193}$

Tomás Prieto Álvarez encaminha, nessa esteira, uma exegese interessante. Embora reconheça a distinção entre Direito e Moral, ele afirma que:

"Portanto, em que pese o ordenamento jurídico não ser, em seu todo, o desenvolvimento de normas morais, pode falar-se, em última instância, de um fundamento moral de uma parte das normas de Direito - as mais nucleares -. Por isso, diz Palombella que 'as condições estruturais do Direito são precisamente de natureza moral (e indisponível)', pelo que se deduz que o Direito aparece dotado de um núcleo de indisponibilidade, que permanece no interior de seu ser."194

Ocorre que as regras morais, que a princípio se aplicam somente para conduzir o indivíduo no caminho da virtude, acabam formando um arcabouço ético que não pode ser desprezado pela ordem jurídica. Essas orientações morais consubstanciam-se em valores apregoados do sentido do justo e do bem que se colocam como elemento de correção material do próprio Direito, ou seja, o ordenamento será tanto mais correto quanto mais aderir a essa proposta ética preconizada pela Moral.

\footnotetext{
${ }^{193}$ Miguel Reale esclarece, preambularmente que "Ao homem afoito e de pouca cultura basta perceber uma diferença entre dois seres para, imediatamente, extremá-los um do outro, mas os mais experientes sabem a arte de distinguir sem separar, a não ser que haja razões essenciais que justifiquem a contraposição.", para alegar depois que "Direito não é algo diverso da Moral, mas é uma parte desta, armada de garantias específicas.” REALE, Miguel. Lições Preliminares de Direito. 26 ed. São Paulo: Saraiva, 2002. p. 41 e 42.

194 "Por tanto, pese que no todo el ordenamiento jurídico es desarrollo de especificas normas morales, puede hablarse en última instancia, de un fundamento moral de una parte de las normas de Derecho - las mas nucleares -. Por eso dice Palombella que 'las condiciones estructurales del Derecho son precisamente de naturaleza moral (e indisponible)', por lo que se deduce que el Derecho aparece necesariamente dotado de un núcleo de indisponibilidad, que permanece en el interior de su ser."ÁLVAREZ, Tomás Prieto. La dignidad de la persona: núcleo de la moralidad y el orden públicos, límite al ejercicio de libertades públicas. Madrid: Thomson Civitas, 2001. p. 108.
} 
Pietro Alvarez ${ }^{195}$ afirma que embora não seja próprio ao Direito fazer morais aos homens, cabe, sim, a ele ordenar a realidade social de acordo com as regras morais. Ele explica que a busca da perfeição individual pela Moral, fim ontológico do homem, não pode ser preterida pelo Direito, antes, serve-lhe de fundamento para a escorreita ordenação jurídica. Segue-se a essas lições a constatação de que: "Nunca $o$ direito pode ser imoral. Uma norma jurídica não pode nunca atentar frontalmente contra as exigências éticas, aquelas que miram a perfeição do indivíduo; dito de outra maneira, a norma de Direito não pode ser nunca diretamente imoral: do contrário, não seria autêntico Direito." 196

O autor ressalta, por exemplo, que o reconhecimento de direitos humanos pela ordem jurídica é uma exigência moral indeclinável. Segundo ele, a reconhecida universalidade e indisponibilidade dos direitos humanos, fundados na natureza peculiar do homem, constituem uma das primeiras exigências morais que o Direito deve tomar para si. Os direitos humanos são, assim, "direitos morais" porquanto nascem de reclames éticos que precedem a ordem jurídica e a invalidam, materialmente, quando esta não os assume de modo adequado. ${ }^{197}$

Miguel Reale invoca, nessa linha, a chamada teoria do "mínimo ético", pela qual o Direito deve recolher disposições éticas mínimas para possibilitar o convívio social. Argumenta ele que: "Como nem todos podem ou querem realizar de maneira espontânea as obrigações morais, é indispensável armar de força certos preceitos éticos para que a sociedade não soçobre." ${ }^{198}$ Desse modo, a positivação da ordem moral pelo Direito conferiria coercibilidade necessária para impedir a transgressão de dispositivos éticos fundamentais à paz social.

Mas o que deve ser sublinhado das lições dos autores citados é a conclusão de que não mais se admite um sistema de normas puramente formal e despreocupado com um conteúdo moral mais substancioso. Ao contrário, a correção material do próprio Direito dá-se quando ele assume exigências éticas fundamentais, consubstanciando por meio das normas jurídicas a Moral que aperfeiçoa os homens. A Moral, nesse sentido, embora não se confunda com o Direito serve de qualificativo da ordem jurídica justa. Em outras

\footnotetext{
${ }^{195}$ Ibid. p. 107 e 108.

196 "Nunca el Derecho pude ser inmoral. Una norma jurídica no puede nunca atentar frontalmente contra las exigencias éticas, aquellas que miran la perfección del individuo; dicho de otra manera, la norma de Derecho no puede ser nunca directamente inmoral: no sería autentico Derecho." Ibid. p. 110.

${ }^{197}$ Ibid. p. 113 a 117.

${ }^{198}$ REALE, Miguel. Lições.... p. 42.
} 
palavras, o Direito, que prestigia a Moral acaba por lograr uma correção material intrínseca, dotando o ordenamento positivo com o atributo da justiça.

Destarte, pode-se afirmar que legitimidade e moralidade se confundem, pois ambas qualificam a ordem jurídica posta com a perspectiva da justiça. Como já se assentou, a noção de legitimidade visa exatamente comprovar a correção material do ordenamento jurídico, pois se diz que a lei é legítima quando amparada por um padrão correcional axiológico. De outra parte, fala-se, também, que a lei formal ganha correção material quando leva em conta certas exigências éticas que denotam a moralidade peculiar da natureza do ser humano, de modo que se pode sentenciar, com tranquilidade, que o ordenamento só é legítimo - e, portanto, materialmente correto - quando moral.

Assim, há uma interdependência necessária entre Moral e Direito, sobretudo quando este último tem a pretensão de ser materialmente hígido, ou seja, legítimo.

Todavia, vale consignar que a Moral não se presta somente a influenciar a produção normativa, qualificando, então, a ordem jurídica posta como justa. Outrossim, a Moral, enquanto preconiza uma atuação virtuosa por parte do indivíduo, é exigível, juridicamente, dos agentes públicos imbuídos da função administrativa. O que se quer dizer é que a Moral não só é fonte para a gênese de normas jurídicas, como também deve ser exigível dos administradores públicos. No campo da Administração Pública, a imprescindibilidade de uma conduta harmônica com a moral encontrou grande respaldo entre os cultores do direito administrativo, porque, ao longo do tempo, percebeu-se que a adstrição rígida dos administradores à lei não foi capaz de conter abusos e desvios, que embora legais, erigiam-se em patente injustiça. ${ }^{199}$

Mais precisamente, uma compreensão rígida do princípio da legalidade abriu espaço para a utilização arbitrária e inconsequente da atuação administrativa. Dessa forma, tanto a doutrina como a jurisprudência dos Tribunais buscaram limitar a atuação dos governantes, preconizando a submissão dos administradores a regras morais não positivadas, visto que extraídas da experiência comum e que ditam uma conduta conforme a honestidade, a lealdade e a boa-fé.

\footnotetext{
199 Consoante às lições de Diogo Moreira Neto, a gênese do conceito de moralidade administrativa surgiu com Hauriou quando de seus comentários às decisões do Conselho de Estado da França. MOREIRA NETO, Diogo de Figueiredo. Moralidade Administrativa: do conceito à efetivação. Revista de Direito Administrativo, Rio de Janeiro, v. 190, out./dez. 1992. p. 5 e 6.
} 
Relata Maria Sylvia Di Pietro ${ }^{200}$ que a chamada "imoralidade administrativa" surgiu ligada à ideia de desvio de poder nas ocasiões em que a Administração atuava estritamente dentro da legalidade, todavia, com o intuito de atingir finalidades irregulares. Certamente, diante de tais desvios, os Tribunais não fecharam os olhos para essa prática condenável e acabaram desenvolvendo as famosas teorias do desvio ou abuso de poder para censurar os vícios de atos legais, mas injustos. O fato é que tais teorias reconhecem, como bem aponta a autora, que "A imoralidade estaria na intenção do agente." 201

De fato, é a disposição interior do agente administrativo que acaba por perverter a finalidade da lei. Na verdade, são os interesses escusos dos administradores que orientam a aplicação da lei para atingir finalidades corrompidas que, sem qualquer dúvida, não representam o escopo do bem comum ao qual a Administração está vinculada. Os exemplos doutrinários sobre o desvio de poder são muito sintomáticos, revelando situações formalmente hígidas, mas moralmente recrimináveis. É o caso, por exemplo, do agente público que, a pretexto de atender necessidade extraordinária de serviço, transfere servidor, amigo ou inimigo seu, para, conforme o caso, prejudicá-lo ou beneficiá-lo; ou, então, quando se desapropria imóvel, por utilidade pública, com o fim de prejudicar ou beneficiar determinada pessoa. Em todos esses casos, o agente age dentro da lei, mas seu intuito principal não é atender ao interesse público, mas objetivos pessoais deturpados.

Nesses termos, exige-se do agente administrativo uma conduta moralmente hígida. Ele há de demonstrar que sua disposição interior é eticamente escorreita, comprovando que ele não visa com o exato cumprimento da lei atingir uma finalidade que não seja o interesse público. Mutatis mutandis, requer-se do agente administrativo uma conduta virtuosa, que sua atuação seja conforme a lealdade, a honestidade e a boa-fé, sem lesar ninguém e sem perverter o sentido da função administrativa cuja finalidade precípua é o bem comum de todos.

Não basta, assim, apenas a observância da lei. O administrador público necessita, também, observar regras morais. Em trabalho prestigiado sobre a moralidade administrativa no direito pátrio, já preconizava Manoel de Oliveira Sobrinho:

"No exato entendimento, o bom administrador, portanto, é aquele que usando da sua competência legal se determina

\footnotetext{
${ }^{200}$ DI PIETRO, Maria Sylvia Zanella. Direito ... p. 76.

${ }^{201}$ Idem.
} 
não só pelos preceitos vigentes, mas também pela moral comum. Há de conhecer, assim, as fronteiras do lícito e do ilícito, do justo e do injusto nos seus efeitos. Por outro lado o direito exercido consagra e regula normas gerais estabelecidas. Muito embora não se cometam faltas legais, a ordem jurídica não justifica no excesso, no desvio, no arbítrio, ou em motivações outras que não encontrem guarida no interesse geral ou público."202

Como esclarece o excerto citado, a ordem jurídica como um todo e, em especial o dever de satisfação do bem comum ao qual a Administração está vinculada, não se contenta com uma atuação administrativa fiel, unicamente, à lei. Quer-se, antes, que os administradores evitem não só as faltas legais, mas também as morais. E, caso o administrador siga em descompasso com a moralidade, os atos assim inquinados merecerão a devida anulação, pois, como já se expôs, o Judiciário não se furta em fulminar os atos lícitos, mas cuja finalidade se encontra, sob o prisma ético, desviada.

Vislumbra-se, assim, certa cogência quanto à exigibilidade de uma conduta moral por parte da Administração, o que leva a alguns doutrinadores conceberem a moralidade como uma legalidade substancialmente qualificada. ${ }^{203}$

Mas é preciso observar, todavia, que mesmo aqueles que adotam posturas mais positivistas, concebendo a moralidade como legalidade, não deixam de reconhecer que a disposição subjetiva do agente público deve se pautar por aspectos éticos de correção. Logo, como elucidam os comentários de Diogo Moreira Neto: "não obstante as divergências quanto aos fundamentos teóricos do conceito de moralidade administrativa, causada pela fidelidade de alguns às premissas do direito puro, há concordância geral quanto à sua aplicabilidade."204

Em que pese a procedência dogmática dos debates teóricos sobre a moralidade, deve se ressaltar que a CF de 1988 acaba por resolver a problemática do caráter jurídico-

\footnotetext{
${ }^{202}$ FRANCO SOBRINHO, Manoel de Oliveira Franco. $O$ controle da moralidade administrativa. São Paulo: Saraiva, 1974. p. 11.

${ }^{203}$ É o caso de José Guilherme Giacomuzzi que defende que a moralidade está vinculda a uma antiga noção de "legalidade substancial". Cf. GIACOMUZZI, José Guilherme. A Moralidade Administrativa e a Boa-Fé da Administração Pública - o conteúdo dogmático da moralidade administrativa. São Paulo: Malheiros, 2002. p. 184.

${ }^{204}$ MOREIRA NETO, Diogo de Figueiredo. Moralidade... p. 30.
} 
positivo da moralidade administrativa, uma vez que o constituinte não só positivou, no art. 37, caput, o chamado "princípio da moralidade", como também vinculou a Administração a observá-lo. Agora, em virtude da própria Constituição, os administradores estão expressamente compelidos a agir de forma virtuosa, de acordo com a moral, sob pena de verem anulados os atos expedidos em contrariedade com preceitos éticos, que coferem correção material à conduta administrativa. Como bem sintetiza Hely Lopes Meirelles: " $A$ moralidade administrativa constitui, hoje em dia, pressuposto de validade de todo ato da Administração Pública (CF, art. 37 caput)". ${ }^{205}$

Diante do panorama exposto, é inegável reconhecer a íntima ligação entre moralidade e legitimidade. Essa relação não se dá somente porque a Moral, quando absorvida pelo Direito, confere correção material à ordem jurídica posta, mas, sobretudo, porque a moralidade é exigida como padrão de correção dos agentes públicos. Em outro sentido, a atuação estatal legítima - ou seja, materialmente correta - só pode ser assim definida enquanto os agentes públicos atuarem de acordo com a virtude que lhes indica as regras de moralidade.

É evidente que a atividade estatal desonesta, corrompida, desviada e lesiva agride o sentimento de justiça da sociedade e por isso não pode, sob nenhum pretexto, ser considera legítima. Afere-se, então, que a moralidade, porquanto coíba qualquer vício que possa escapar ao cumprimento frio da lei, erigi-se como elemento de higidez da conduta dos agentes públicos, evidenciando que o padrão de correção supera as barreiras da legalidade, para alcançar, também, a legitimidade.

Portanto, a noção de legitimidade preconizada pelo art. 70, caput, da Constituição não deixa de expressar uma exigência de moralidade. A perspectiva ética deduzida das normas morais que deve influenciar, obrigatoriamente, os gestores públicos acaba conferindo legitimidade à atividade financeira do Estado. Assim, legitimidade e moralidade se confundem, pois o escopo de ambas é apregoar a justiça material por meio da observância de valores e normas éticas, afastando-se da idéia de que a correção se consubstancia, meramente, com o atendimento de requisitos formais de validade.

${ }^{205}$ MEIRELLES, Hely Lopes. Direito...p. 90. 


\subsection{Legitimidade e Legalidade.}

A princípio, legalidade e legitimidade parecem idéias totalmente contrapostas, sobretudo porque se extrai do sentido de legalidade uma noção de vinculação silogística a um corpo de normas positivas puramente formais. A noção de legitimidade teria surgido, justamente, para combater essa visão formalística de legalidade que, por si só, é incapaz de refletir a justiça. Assim concebida, a legalidade reclamaria o qualificativo da legitimidade que seria capaz de torná-la substancialmente válida. Ou seja, seria preciso afirmar que a lei é legítima para expressar sua validade material, esclarecendo que a norma posta é correta na medida em que adere a padrões axiológicos afinados com a realização da justiça.

Porém, essa noção de legalidade puramente formal parece superada, pois como relata Manoel Goçalves: "O formalismo contentava-se com a observância da lei pela Administração e pelo Judiciário, mas a lei poderia ter qualquer conteúdo, mesmo aberrante dos valores de justiça, de liberdade, equidade etc."206

Em seu nascedouro, a legalidade ligava-se à necessidade de limitação do poder por meio de normas impessoais e abstratas, impedindo que a vontade arbitrária dos detentores do poder prejudicasse a liberdade dos indivíduos. Com base na força das leis, os indivíduos restariam assegurados, evitando que os abusos do Monarca lhes pudessem tolher a autonomia privada. ${ }^{207}$

Todavia, embora se possa advogar que noção de legalidade surgiu para conter abusos e arbítrios, é preciso notar que, ao longo do processo civilizatório, a legalidade acanhada e baseada em padrões formais de validade rvelou-se inábil para proteger os aspectos mais fundamentais da dignidade da pessoa humana. Manoel Gonçalves ${ }^{208}$ indica que os regimes totalitários e os conflitos armados da primeira metade do século XX contribuíram sobremaneira para derrubar a noção formalista de legalidade, tendo em vista que a lei servira para justificar o que quer que seja, mesmo as mais perversas desumanidades.

\footnotetext{
${ }^{206}$ FERREIRA FILHO, Manoel Gonçalves. Princípios...p. 108.

${ }^{207}$ Como leciona Maria Sylvia Di Pietro: "Substitui-se a idéia da vontade do rei como fonte de todo o Direito pela a idéia da lei como resultante da vontade geral. Adotando-se, o princípio da separação dos poderes, tirou-se do Poder Executivo a capacidade de ditar leis gerais, já que estas constituem a expressão da vontade geral representada pelo Parlamento; ao Executivo compete apenas editar atos singulares previamente disciplinados em lei." DI PIETRO, Maria Sylvia Zanella. Discricionariedade Administrativa na Constituição de 1988. $2^{\text {a }}$ ed. São Paulo:Atlas, 2007. p. 21.

${ }^{208}$ FERREIRA FILHO, Manoel Gonçalves. Princípios...p. 107.
} 
A lei desprovida de qualquer conteúdo ético não mais poderia servir como padrão de correção sobre o qual se assenta o Direito. Argumentou-se, nesse aspecto, que os legisladores estão limitados por critérios de justiça material que lhes submetem ao reconhecimento de um corpo de valores suprapositivos longe dos quais a produção normativa padeceria, sob a perspectiva da validade, de uma capital deficiência.

Nesse sentido, é preciso trazer à colação a doutrina de Jacques Chevallier ${ }^{209}$ que apregoa a distinção entre o Estado de Direito e o Estado Legal. Para o autor, o chamado Estado Legal é uma opção política fundamental dos povos para assegurar a supremacia dos corpos legislativos de modo que toda atuação administrativa fica não só limitada, mas condicionada pela lei. Porém, no Estado Legal não se concebe limitações ao legislador, sendo o Parlamento não só um órgão supremo, mas também soberano. Já o Estado de Direito é voltado fundamentalmente para a salvaguarda dos direitos dos homens, limitando o poder do Legislativo. Destarte, o Estado de Direito coloca-se em oposição flagrante ao Estado Legal, pois pressupõe que a ordem jurídica positiva acolha direitos e garantias fundamentais em desprestígio ao poder absoluto dos órgãos legislativos.

Inserida nessa concepção de Estado de Direito, a legalidade sofreu um sensível alargamento. Ela deixou de ser concebida como um corpo positivo de normas, ao qual se deve obediência, para preconizar uma submissão ao Direito. Registre-se, todavia, que a posição central dos interesses dos cidadãos faz com a acepção de Direito coadune-se com um substrato axiológico que evidencia a validade substancial do ordenamento jurídico. Logo, o Direito ao qual se deve sujeição conforma-se com um sistema jurídico totalizante que recolhe não somente leis ordinárias, mas também um corpo de princípios e de direitos fundamentais que constituem um marco de correção material da atividade estatal. ${ }^{210}$

Consoante as lições de Cabral de Moncada: "A legalidade não se reduz ao estado legislativo, exige o estado-de-direito com o conteúdo de um estado de justiça."211 Mais detidamente ele afirma:" para que a legalidade não se transforme na idolatria da burocracia estatal, é preciso que ela se legitime, ou seja, que veicule elementos de justiça

\footnotetext{
${ }^{209}$ CHEVALLIER, Jacques. L'État de droit. Paris: Montchrestien, 1992. p. 31 a 34.

${ }^{210}$ Conforme observa Domingo Sesin: "La superación del criterio legalista estricto es levada a cabo por una nueva tendencia doctrinal que otorga significativa importancia a los principios generales del derecho, los cuales - junto con la ley - pasan a constituir el marco de juridicidad que sirve como fuente de la actividad administrativa." SESIN, Domingo. Administración Pública: actividad reglada, discrecional y técnica. Buenos Aires: Deopalma, 1994. p.7.

${ }^{211}$ MONCADA, Luis S. Cabral de. Estudos de Direito Público. Coimbra: Coimbra ed., 2001. p. 424.
} 
material, quais sejam, uma adequada protecção dos direitos fundamentais e a obtenção de níveis adequados de bem estar social, assim concretizando certos princípios gerais." 212

Não se cogita, dessa maneira, que legalidade seja concebida segundo uma análise meramente formal, sem uma preocupação maior em exigir condutas eticamente hígidas. A correção material que se extrai da noção do Direito faz com que mandamentos valorativos componham o conteúdo prescritivo veiculado pela legalidade. Assim, o reconhecimento de princípios gerais de direito e de todo um elenco de diretos fundamentais abre campo para aplicação positiva de valores materiais que trazem à esfera da legalidade uma adjetivação mais substantiva.

Por outro lado, é preciso sublinhar que essa noção mais alargada de legalidade operacionalizou-se pela encampação constitucional de valores ditos suprapositivos. Afirma Mauro Cappelletti ${ }^{213}$ que o constitucionalismo atual caracteriza-se pela positivação do direito natural. Ele constata que os direitos inatos e os princípios gerais ingressaram na esfera constitucional como uma garantia de "desaplicação" de leis opostas à afirmação material de justiça. Assim, pode-se dizer que as Constituições costumam veicular a necessidade de se observar um Direito desapegado de uma concepção estrita da lei. É possível reconhecer, sobretudo nas normas constitucionais, a existência de um plexo normativo de alta densidade axiológica que compõe a noção de um Direito que não acolhe a lei, formalmente válida, mas materialmente injusta.

Segundo Manoel Gonçalves ${ }^{214}$, foi a Lei Fundamental da então República Federal Alemã de 1949, que pela primeira vez, reconheceu a necessidade de adstrição a um Direito distinto da lei. Apregoava o art. 20, alínea 3, da citada Lei Maior que "O Poder Legislativo está subordinado à ordem constitucional; os Poderes Executivo e Judiciário obedecem à lei e ao Direito." Em período mais recente, a Espanha seguiu o mesmo método, asseverando no art. 103.1 da sua Constituição que a Administração Pública está vinculada não só pela lei, como também pelo Direito.

O que vale notar nos exemplos citados é que a Constituição, ao submeter os poderes públicos a um Direito distinto da lei, acaba positivando a necessidade de se observar preceitos axiológicos que apregoam uma vinculação à realização da justiça. $\mathrm{O}$ Direito, portanto, não se conforma com a obediência tacanha às leis, exige antes uma

\footnotetext{
212 Ibid. p. 423.

213 CAPPELLETTI, Mauro. El control judicial de la constitucionalidad de las leys en el derecho comparado. México: Universidad Autónoma de México, 1966. p. 26 e 27.

${ }^{214}$ FERREIRA FILHO, Manoel Gonçalves. Princípios...p. 109.
} 
conduta consentânea com valores fundamentais. Nesses termos, a ordem constitucional fundamento estruturante do sistema jurídico - preocupou-se em ditar não somente comportamentos precisos, mas também em prescrever a observância de mandatos axiológicos que garantem, em última análise, que os poderes do Estado portem-se de modo adequado, respeitando os direitos dos cidadãos e agindo em conformidade com a justiça material.

No caso pátrio, a CF de 1988 não submeteu a Administração à lei e ao Direito, mas, além de reconhecer um extenso rol de direitos e garantias fundamentais, prescreveu no art. 37, caput, que a Administração Pública deve observar os princípios da legalidade, impessoalidade, publicidade, moralidade e eficiência. Essa constrição principiológica à Administração não deixa de revelar a intenção do constituinte em fazer com que o Poder Público adira a valores capazes de tornar sua atuação justa e preocupada com a efetiva satisfação das necessidades públicas, pois, como já se afirmou, a simples observância da lei não é apta a gerar níveis adequados de bem estar social.

Desse modo, a legalidade que se exige do Poder Público não pode ser confundida com a mera subordinação à lei. É preciso proclamar que a Administração segue submetida, outrossim, às normas constitucionais, especialmente àquelas que veiculam mandatos axiológicos e, portanto, conformadoras de uma conduta materialmente justa.

A Constituição surge, assim, como a normativa central de vinculação da atuação estatal. Como leciona Gustavo Binenbojm: "Com efeito, em vez de a eficácia operacional das normas constitucionais - especialmente as instituidoras de princípios e definidoras de direitos fundamentais - depender sempre de lei para vincular o administrador, tem-se hoje a Constituição como fundamento primeiro do agir administrativo.,215

Essas lições revelam que as normas constitucionais não são um mero programa a ser cumprido, tampouco são declarações admoestativas. Ao contrário, as normas constitucionais - inclusive os princípios, os direitos e as garantias fundamentais - possuem uma influência decisiva no âmbito de vinculação dos agentes públicos. Destarte, a axiologia positivada no texto constitucional figura, também, como padrão de correção de condutas, apregoando a necessidade de se realizar uma conduta materialmente válida e harmônica com os ditames da justiça.

${ }^{215}$ BINENBOJM, Gustavo. Uma Teoria... p. 36 e 37. 
Reafirme-se, então, que o sentido de vinculação expresso pela legalidade diz respeito, também, às normas constitucionais. A compreensão daquilo que seja a legalidade passa por uma ampliação de modo a exigir condutas ajustadas aos valores estruturais do ordenamento, que, por sua vez, estão expressos no Diploma Maior.

Nesse sentido, a noção de legitimidade vai ao encontro dessa concepção substantiva de legalidade. Tal qual o sentido de legitimidade, a positivação de preceitos axiológicos pela via constitucional visa conferir uma validade material ao ordenamento jurídico, atrelando-o ao reclame da justiça. Assim, o significado de legitimidade que se extrai do art. 70 da Constituição aproxima, e muito, dessa idéia mais alargada de legalidade.

Confira, por exemplo, as lições de Ricardo Lobo Torres. Por primeiro, ele concebe a legalidade sob uma perspectiva material ao afirmar que "o controle $d a$ legalidade não se exaure em uma concepção formal, senão que se consubstancia no próprio controle das garantias normativas ou da segurança dos direitos fundamentais". 216 De outro lado, ao tratar do controle da legitimidade ele não deixa de aludir que esse aspecto da fiscalização leva em conta princípios existentes no seio da Constituição. Afirma ele que: "O aspecto da legitimidade, por conseguinte, engloba princípios constitucionais orçamentários e financeiros derivados da idéia de segurança jurídica ou de justiça". ${ }^{217}$

Nota-se, dessa maneira, que a legalidade não é uma noção totalmente oposta à de legitimidade. Ambas se confundem na medida em que valores radicados no sentido de justiça se encontram expressamente positivados pelo ordenamento e figuram como paradigmas de correção material dos atos de gestão financeira. Considerando que a Constituição é o diploma que recolhe esses valores, pode-se dizer que a legitimidade verifica-se, nesses termos, sob o viés de legalidade constitucionalmente qualificada.

A aderência da atividade financeira do Estado às disposições da Constituição, em especial aos preceitos de maior carga axiológica, acaba por evidenciar a sua legitimidade, uma vez que os princípios e as garantias constitucionais são núcleos de condensação de valores, contribuindo decisivamente para a adequação substantiva da gestão dos recursos públicos. ${ }^{218}$

\footnotetext{
216 TORRES, Ricardo Lobo. Tratado... p. 498.

${ }^{217}$ Ibid. p.508.

${ }^{218}$ BINENBOJM, Gustavo. Uma Teoria... p. 38.
} 
Pode-se afirmar, assim, que a Constituição é critério imediato de legitimidade da atividade financeira. Por óbvio, a gestão dos recursos públicos não pode se afastar de princípios constitucionais reitores como os da moralidade, igualdade, eficiência e impessoalidade. Outrossim, a Constituição impõe um regime de normas programáticas e de direitos fundamentais com os quais a atividade financeira deve, obrigatoriamente, coadunar-se. Longe dessas diretivas constitucionais a atuação financeira padecerá de grave ilegitimidade e não poderá, sob o prisma da justiça material, ser considerada válida e correta.

Portanto, a legalidade concebida em sentido amplo, que preconiza uma vinculação a valores constantes da normativa constitucional, não se contrapõe à noção de legitimidade. Pelo contrário, a constatação da legitimidade sugere uma análise sobre a conformação dos atos contrastados com a axiologia encampada pelo Texto Constitucional, de modo que a atividade financeira do Estado eventualmente ilegítima pode ser classificada, também, como inconstitucional.

\subsection{Legitimidade e Economicidade.}

A economicidade indica, em primeira apreensão, uma idéia de que os recursos públicos devem ser gastos de maneira parcimoniosa, sem prodigalidade ou desperdícios. Em síntese, a economicidade restaria concretizada quando se gasta o menos possível. Essa noção de economicidade é, em alguma medida, prestigiada pelo TCU que, no Manual de Auditoria Operacional, afirma: "A economicidade é a minimização dos custos utilizados na consecução de uma atividade, sem o comprometimento dos padrões de qualidade (INTOSAI 3000/1.5, 2004). Refere-se à capacidade de uma instituição em gerir adequadamente os recursos alocados à sua disposição." 219

As lições apregoadas pelo TCU são elucidativas. Deduz-se delas que a economicidade requer o gasto mínimo sem, contudo, comprometer os padrões de qualidade da gestão pública. Destarte, a aferição da economicidade não verifica apenas se o gasto foi

${ }^{219}$ BRASIL. Tribunal de Contas da União. Manual de auditoria operacional / Tribunal de Contas da União. $3^{a}$ ed. Brasília: TCU, Secretaria de Fiscalização e Avaliação de Programas de Governo (Seprog), 2010. p. 11. 
módico ou comedido, mas, sobretudo, se com o menor custo foi possível chegar ao melhor índice de resultados. Como bem ressalta este órgão de controle, a economicidade supõe que os recursos alocados sejam geridos de modo adequado, o que contraria qualquer impropriedade quanto à efetiva satisfação das necessidades públicas. Requer-se, então, que os bens e os serviços públicos oferecidos sejam hábeis para atender aos reclames sociais, mais ainda, que eles sejam eficientes e que, principalmente, sejam financiados com a menor soma de valores possível.

Vislumbra-se, nessa linha, o fato de que o TCU compreende a economicidade dentro de um esquema complexo que leva em conta matizes como a eficiência, a eficácia e a efetividade do gasto público. O Manual de Auditoria Operacional do TCU ${ }^{220}$ possui um exemplo gráfico que bem ilustra a relação entre esses matizes:

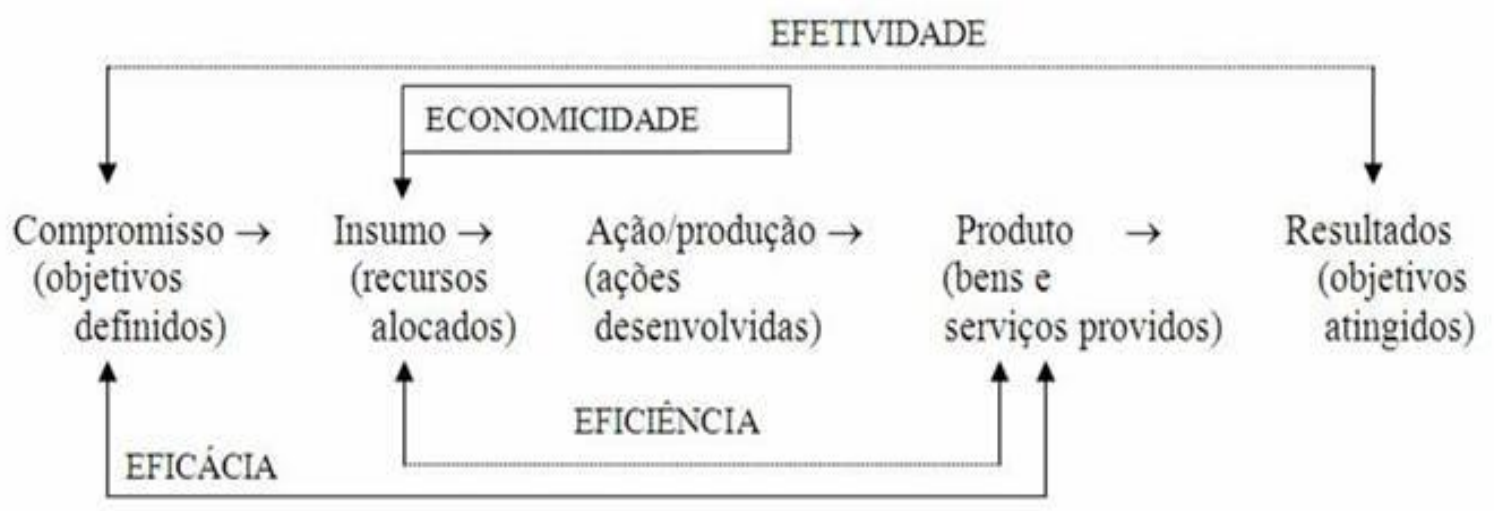

De início, é possível perceber que a aferição da economicidade incide direta e exclusivamente no âmbito dos recursos alocados (ou insumos) com escopo de verificar se as ações desenvolvidas para a consecução de bens e serviços foram financiadas a custos mínimos. A eficiência, de seu turno, está intimamente relacionada ao conceito de economicidade, uma vez que denota a procedência da equação custo-benefício. Constata-se a eficiência pela otimização dos recursos empregados na medida em que estes desembocam na maximização dos bens e serviços oferecidos ao mínimo custo possível. ${ }^{221}$

${ }^{220}$ Idem.
${ }^{221}$ Segundo o Manual de Auditoria Operacional do TCU: “A eficiência é definida como a relação entre os
produtos (bens e serviços ) gerados por uma atividade e os custos dos insumos empregados para produzi-los,
em um determinado período de tempo, mantidos os padrões de qualidade. Essa dimensão refere-se ao
esforço do processo de transformação de insumos em produtos. Pode ser examinada sob duas perspectivas:
minimização do custo total ou dos meios necessários para obter a mesma quantidade e qualidade de 
Já a eficácia e a efetividade não dizem respeito, ao menos diretamente, ao modo como se aplicam os recursos públicos. ${ }^{222}$ Confira que a eficácia, por exemplo, mensura o cumprimento de metas estabelecidas para a produção de bens e serviços. As ações serão tanto mais eficazes quanto maior o adimplemento das metas estabelecidas, contudo, deve sublinhar-se o cuidado na definição das metas em contraste com a real capacidade de atuação do setor, pois a adoção de objetivos subestimados pode levar a conclusões erradas quanto à eficácia.

A efetividade, por sua vez, relaciona-se com a mensuração genérica da atuação do setor público. Por meio dela, pretende-se medir os resultados socioeconômicos obtidos com a gestão pública. Analisa-se, nesse particular, o impacto que a atividade financeira causou no seio social.

O que se nota, entretanto, é que a análise da economicidade não está alijada de uma verificação de desempenho. Se considerado o processo global de avaliação das decisões públicas, não se pode conceber a economicidade dentro de uma esfera relacionada, exclusivamente, à quantificação do gasto. A correta compreensão da economicidade passa, sim, pela aferição da qualidade do gasto, sem dispensar - e isso é o elemento principal - uma preocupação com os custos. Portanto, é possível afirmar que a economicidade sugere que se alcance uma equação ótima na variável custo-benefício.

A economicidade exige, então, que os parcos recursos públicos sejam aplicados da melhor maneira de modo a se potencializar e maximizar os bens e serviços públicos oferecidos, tendo em conta, é claro, a preocupação de que a atividade foi financiada com a menor soma de valor possível. Quer-se que os efeitos da atuação pública sejam otimizados porquanto se verifique, no seio social, a produção de resultados expressivos ao menor custo praticado.

Todavia, não se pode deixar de reconhecer que a noção de economicidade exposta é excessivamente ligada ao âmbito econômico e à teoria geral da administração. É preciso ressaltar que a doutrina jurídica compôs um quadro de significação peculiar à economicidade veiculada pelo art. 70 da CF de 1988. Bem anota Paulo Soares de

produto; ou otimização da combinação de insumos para maximizar o produto quando o gasto total está previamente fixado. Nesse caso, a análise do tempo necessário para execução das tarefas é uma variável a ser considerada. A eficiência pode ser medida calculando-se e comparando-se o custo unitário da produção de um bem ou serviço. Portanto, podemos considerar que o conceito de eficiência está relacionado ao de economicidade." Ibid. p. 12.

${ }^{222}$ Idem. 
Bugarin $^{223}$ que a economicidade tem aspectos plurissignificativos e, por isso mesmo, comporta uma abordagem multidisciplinar que passa tanto pela doutrina jurídica, como pela ciência econômica e a teoria geral da administração.

Vale destacar, inicialmente, que a economicidade não é um conceito forjado pelas letras jurídicas. O ordenamento buscou um termo advindo de outras searas, fazendo com que a compreensão jurídica da economicidade precise buscar subsídios nas ciências em que ela se originou. Consoante doutrina de Gustavo Massa Ferreira Lima: "A economicidade não nasceu no meio do debate jurídico, a expressão foi apropriada da ciência econômica sendo também fruto da evolução da Administração Pública e Privada." 224 Desse modo, a formulação da dogmática jurídica sobre a economicidade não prescinde de uma análise voltada às ciências da Administração e da Economia.

O citado Manual de Auditoria do TCU focaliza a economicidade no contexto da ciência econômica e da teoria geral da administração, empreendendo a partir dela uma avaliação qualitativa quanto ao emprego dos recursos financeiros. Ressalte-se que sob o prisma das ciências econômicas essa análise da qualidade do gasto é um aspecto fundamental, tendo em vista a preocupação primordial com a questão do retorno do capital investido. Medir os efeitos da gestão econômica, perquirindo sobre aspectos qualitativos é uma exigência indeclinável, pois uma atuação racional não pode conviver com resultados fracos que representariam, em última análise, a perda do capital inicialmente investido.

Mas se no âmbito privado a excelência qualitativa e o consequente retorno do capital investido revelam-se com a maximização dos lucros, no setor público prepondera uma avaliação de custo/benefício. Conforme entendimento de Paulo Soares Bugarin:

"enquanto que no plano privado o vetor essencial para a avaliação de uma decisão alocativa de recursos se dá na comparação entre custos e resultados econômicos, no plano público se dá na busca de uma metodologia que permita uma estimativa objetivamente aferivel dos custos e benefícios sociais, permitindo a adoção de alternativa de investimento

\footnotetext{
${ }^{223}$ BUGARIN, Paulo Soares. O princípio... p. 105.

224 LIMA, Gustavo Massa Ferreira. O Princípio Constitucional da Economicidade e o Controle de Desempenho pelos Tribunais de Contas. Belo Horizonte: Fórum, 2010. p. 32.
} 
que melhor resultado estratégico político-social se alcance.",225

Por óbvio, o lucro não é o objetivo da atuação do setor público, antes a Administração tem por escopo promover níveis adequados de bem estar social. Para tanto os recursos públicos devem, obrigatoriamente, estar voltados à satisfação das carências matérias do ser humano. Outrossim, os recursos públicos não estão à disposição do arbítrio do gestor, uma vez que a sua natureza pública os tornam indisponíveis para o desperdício, o despropósito e a prodigalidade, indicando ao gestor que o gasto públicos deve ser realizado com eficiência de modo a lograr os melhores resultados com a menor soma possível.

O gestor deve conscientizar-se que os reclames sociais são infindáveis e as reservas financeiras para atendê-los são limitadas o que, certamente, o constrange ao emprego racional e eficiente dos recursos públicos. Nesses termos, ainda que uma determinada ação colha resultados efetivos é preciso indagar sobre a quantidade dos recursos empregados, pois, fatalmente, inúmeras demandas sociais não poderão ser satisfeitas, tendo em vista o notório descompasso entre as contingências sociais e os recursos para custeá-las. Assim, faz-se imprescindível a análise de custo-benefício apregoada pela economicidade. Se, de um lado, é preciso maximizar os resultados, por outro, é preciso minimizar os custos no intuito de se preservar recursos para prover, na medida das possibilidades, o adimplemento do maior número de necessidades públicas existentes.

Pelas razões consignadas, a economicidade, sob a perspectiva econômicoadministrativa, é fator fundamental para apurar a higidez da atuação financeira. A análise de custo-benefício exercida pelos órgãos de controle acaba por preservar os recursos públicos, aumentando a capacidade de investimento do Estado. Isso tudo, sem desconsiderar a premência de se atender, efetivamente, os reclames sociais, pois, como exposto, a análise de custo-benefício possibilita uma avaliação qualitativa do gasto de modo que a economicidade não se configura quando se gasta menos, mas constata se com o menos era possível realizar mais.

${ }^{225}$ BUGARIN, Paulo Soares. O princípio... p. 120. 
Ainda, é preciso dizer que a doutrina jurídica, ao comentar a economicidade inscrita no art. 70 da CF, não deixa de relacioná-la à análise de custo-benefício. Antes, percebe-se que os juristas se apoiaram nas teorias econômicas e administrativas para explicar o conteúdo normativo da economicidade. ${ }^{226}$

Veja, por exemplo, o que afirma Régis de Oliveira: “A economicidade diz respeito à obtenção da melhor proposta para a efetuação da despesa pública, isto é, se o caminho perseguido foi o melhor e o mais amplo para chegar à despesa e se a ela fez-se com modicidade, dentro da equação custo-benefício." 227 José Afonso da Silva envereda pela mesma linha ao lecionar que: "o controle de economicidade, que envolve também a questão de mérito, para verificar se o órgão procedeu na aplicação da despesa pública, de modo mais econômico, atendendo, por exemplo, uma adequada relação custobeneficio." 228

Como se nota, a construção da dogmática jurídica sobre a economicidade não prescinde de conceitos auferidos de outras ciências, ao contrário, a relação custo-benefício é a base sobre a qual se constrói a prescrição do ordenamento no que diz respeito à observância da economicidade. Entretanto, é preciso esclarecer que o contraste jurídico da economicidade deixa de indagar sobre nuances técnicas, para dotar a relação custobenefício de um viés mais axiológico.

Uma atenção mais profunda sobre as variáveis técnicas e científicas da equação custo-benefício é totalmente negligenciada pela doutrina jurídica, que, por sua vez, prefere reconhecer a economicidade como um mandato de otimização que exige, em última instância, a correção material da atuação financeira do Estado. ${ }^{229}$

Como esclarece Gustavo Ferreira Lima: "Na ciência econômica, os valores sociais não ocupam um lugar tão relevante quanto o assumido no mundo jurídico. Por isso, quando a economicidade é transportada para a seara jurídica, deve ser feita uma releitura, acrescendo-se parâmetros axiológicos inerentes à visão jurídica." $230 \mathrm{O}$ autor segue afirmando que a economicidade, do ponto de vista jurídico, traduz-se no dever de

\footnotetext{
${ }^{226}$ Cf. CONTI, José Maurício. Direito... p.5. MILESKI, Helio Saul. O Controle.... p. 250.

227 OLIVEIRA, Régis Fernandes. Curso... p. 391.

228 SILVA, José Afonso da. Curso... p. 730.

229 Em obra sobre ciência das finanças, Nicolò Pollari chega a formular uma equação matemática para explicar a relação custo-benefício. A equação é deveras sofisticada e leva em conta aspectos e variáveis de notório rigor técnico. Todavia, a doutrina jurídica se furta em deter-se sobre formulações científicas da equação custo-benefício. Talvez, porque, como reconhece o próprio Pollari, existem na esfera pública bens e objetivos intangíveis, como a vida e a saúde, que não podem ser matematicamente mensurados. Cf. POLLARI, Nicolò. Scienze delle finanze. Roma: Laurus Robuffo, 1995. p. 116 a 119.

${ }^{230}$ LIMA, Gustavo Massa Ferreira. O Princípio... p. 33.
} 
promoção do bem estar social. A análise de economicidade não utiliza, desse modo, fórmulas matemáticas para constatar a correção, mas, sim, verifica se os escassos recursos foram alocados de maneira a alcançar o maior grau de satisfação social. In verbis:

"O custo-benefício não deve ser visto na gestão do patrimônio público como simples operação matemáticofinanceira em que o resultado positivo espelha o lucro. O que se deseja é alcançar o maior grau de satisfação social. Esses valores são indissociáveis do conceito de economicidade como parâmetro de avaliação das despesas públicas. ",231

Na ótica do Direito, o escopo central da economicidade é, portanto, o de constranger o agente público a envidar esforços para, senão eliminar, ao menos mitigar os graves problemas que grassam no seio social. Mais precisamente, a economicidade, diante da escassez financeira, deve ser o principal vetor a orientar a alocação e aplicação dos recursos públicos, exigindo do gestor uma ponderação quanto às prioridades e quanto ao melhor modo de realização das despesas para que, ao final, sejam auferidos os melhores resultados sociais possíveis.

Note que o cenário da escassez de verbas públicas não pode ser desprezado. Se sopesado o fato de que as necessidades humanas mais elementares ficam ao desabrigo da atuação do Estado por falta de respaldo financeiro, é um reclame ético indeclinável empregar os recursos existentes da melhor forma. Nesse sentido, a procedência da equação custo-benefício adquire uma importância capital, pois com maior razão deve o gestor buscar a otimização dos resultados socioeconômicos, uma vez que a base de financiamento será incapaz de agasalhar todas as contingências humanas.

Desse modo, a observância da economicidade figura-se como elemento de correção material das finanças públicas, porquanto apregoa que a atividade financeira deve alcançar os melhores resultados a um custo mínimo, aproveitando, ao máximo, os recursos disponíveis. Em outras palavras, a gestão dos bens e valores públicos só se reputa justa, legítima e interessada em concretizar o bem comum caso obtenha índices de excelência quanto ao desempenho da gestão financeira.

${ }^{231}$ Ibid. p. 33 e 34. 
Ricardo Lobo Torres ${ }^{232}$ chega a supor, nesse diapasão, que o controle da economicidade é o controle da própria justiça. Observe que não existe justiça financeira se o gasto público for ineficaz, desequilibrado e dispendioso. A satisfação das necessidades sociais e individuais é inexaurível em relação ao conteúdo dos cofres públicos e, portanto, requer, como um dever de justiça, a maximização dos resultados obtidos com a aplicação dos parcos recursos do erário.

Assim, a economicidade inscrita no art.70 da CF de 1988 expõe uma alta carga axiológica. A relação custo-benefício por ela preconizada não indaga, nesse particular, sobre os aspectos técnicos presentes nas variáveis "dispêndio" e "resultados", mas prescreve ao gestor público a inafastável constrição de bem empregar numerário estatal, extraindo deles o maior benefício social possível.

Concebida nessa perspectiva, a economicidade acaba por se cofundir com a legitimidade. Certamente, a atuação financeira legítima supõe que os recursos insuficientes sejam aplicados de modo eficaz, logrando o máximo êxito no atendimento das indigências constatadas na sociedade. Nesses termos, o sucesso da equação custo-benefício é fator denotativo da legitimidade da atuação financeira. Só se pode qualificar de legítima a atividade financeira que realiza as despesas públicas com racionalidade, equilíbrio e eficiência, evidenciando que a gestão buscou potencializar seu desempenho em atenção ao notório descompasso entre as receitas e os reclames sociais.

Logo, a economicidade e a legitimidade não são noções opostas ou inconfundíveis. É preciso ressaltar que a economicidade vai ao encontro do desiderato por correção material empreendido pela idéia de legitimidade. Diante da carência de verbas públicas, a justiça e a consecução do bem comum somente são desveladas com a procedência da relação custo-benefício de modo que a apuração de legitimidade na atuação financeira do Estado pressupõe a observância compulsória da economicidade.

${ }^{232}$ In verbis: “O conceito de economicidade, originário da linguagem dos economistas, corresponde, no discurso jurídico, ao conceito de justiça." TORRES, Ricardo Lobo. Tratado... p. 508 


\section{A AFERIÇÃO DA LEGITIMIDADE}

A legitimidade a ser apurada quando da fiscalização das contas públicas verifica, em última análise, a justiça inerente à atuação financeira do Estado. Como se expôs, o exame da legitimidade indaga sobre a justiça, a moralidade e o efetivo atendimento das necessidades humanas no intuito de demonstrar a correção material na condução das finanças públicas. Em síntese, a fiscalização quanto à legitimidade visa constatar se a gestão dos recursos públicos foi boa, moral, equânime, justa e preocupada com a consecução do interesse público.

Mas segue-se a essa constatação uma celeuma filosófica assaz complexa. Não obstante a legitimidade sirva para averiguar a correção substancial na gestão dos recursos públicos, não se pode negar o questionamento filosófico acerca do que é a justiça, a verdade e a bondade nos tempos contemporâneos. Em outros termos, não se deve negligenciar o fato de que muitos perquirem sobre a possibilidade e os meios de se reconhecer, racionalmente, aquilo que seja justo, moral, correto e bom.

Cogita-se, portanto, sobre o que seria, realmente, uma atuação legítima que desemboca na correção material da atividade financeira. Quando se diz que o controle da legitimidade requer uma conformidade material com a justiça, surge, então, a dificuldade consistente no julgamento daquilo que é bom ou mau, na identificação do que seria justo ou injusto, certo ou errado e verdadeiro ou falso.

Alexandre Garrido Silva afirma, por exemplo, que há uma imperiosa necessidade de se buscar a legitimidade em critérios racionais, ao contrário dos jusnaturalistas que examinam a correção fundamentando-a em pareceres metafísicos ou em características inatas ao homem. Diz ele que a própria busca pela legitimação supõe um esforço argumentativo racional que evidencie a pretensão pela correção. ${ }^{233}$ Aponta o autor que:

\footnotetext{
${ }^{233}$ Para o autor, os juízos morais não são passíveis de verdade a menos que se possa contrapô-los a uma ordem objetiva de valores imutáveis ou apriorísticos. Nesse sentido, os juízos morais somente são passíveis de correção ou incorreção na medida em que fundamentados na argumentação racional e prática. SILVA, Alexandre Garrido da. Direitos Humanos, Constituição e Discurso da Legitimação: Possibilidades e Limites da Teoria do Discurso. In. TORRES, Ricardo Lobo (org.). Legitimação dos Direitos Humanos. $2^{\mathrm{a}}$ ed. Rio de Janeiro: Renovar, 2000. p. 41 a 44.
} 
“a noção de 'legitimação' contém, em primeiro lugar, uma forte conotação dialógica, e, portanto, argumentativa. 'Legitimação' parece ser um conceito avesso às tentativas de formulação absolutas, metafísicas ou apriorísticas, e, portanto, um conceito mais dinâmico, no sentido de que, normalmente, é o resultado de um esforço argumentativo de justificação racional de direitos e princípios. ${ }^{234}$

Assim, a legitimidade não seria aferida por meio de aporias: o filósofo não encontra a verdade, a correção e a justiça em opiniões etéreas ou em critérios objetivos concebidos a priori. ${ }^{235}$ Antes, "a 'legitimidade' significa o consenso empírico sobre a adequação entre a ordem jurídica e os valores compartilhados pela sociedade". 236

A apuração da correção, da justiça, da validade material seria determinada, nesse sentido, pelo consenso auferido com o esforço argumentativo. É o chamado aspecto dialógico - de diálogo - construído entre os membros da comunidade que reconhece a validade e a justiça indicadas pela legitimidade. Fora desse ambiente discursivo, no qual se possibilita a formação de um acordo entre todos os partícipes do processo dialógico, seria impossível, sob a perspectiva racional, afirmar a regularidade material de uma proposição.

Nota-se, destarte, que a posição firmada por Alexandre Garrido é fortemente marcada pela teoria do discurso de Habermas e, adotada em alguma medida por Alexy. Vitor Souza Lima ${ }^{237}$ debruça-se sobre a obra de Habermas e explicita que para este filósofo a racionalidade dos juízos de correção está integrada na estrutura da linguagem de modo que as pretensões factuais de validade restam comprovadas mediante um discurso e uma argumentação capazes de produzir consensos motivados.

\section{Revela Vitor Souza Lima que:}

\footnotetext{
${ }^{234}$ Ibid. p. 34.

235 " A idéia de uma fundamentação absoluta, compreendida com a busca de um referencial extramundo (por exemplo, a idéia de uma ordem objetiva e imutável de valores fora da prática social cotidiana) ou, então, de 'algo' inato ao homem, somente conduz o filósofo a aporias.” Ibid. p. 44.

${ }^{236}$ Ibid. p. 36.

237 BLOTTA, Vitor Souza Lima. Habermas e o Direito: da normatividade da razão à normatividade jurídica. São Paulo: Quartier Latin, 2010. p. 196 a 198.
} 
"a verdade ou a realidade - bem como as outras pretensões de validade, embora com seus respectivos atos da fala e suas formas próprias de 'redenção' em debates argumentativos passa a compor para Habermas a totalidade de estados asseverados e possivelmente comprovados como verdadeiros em face de argumentos contrários. Essas asserções teriam de ser, portanto, capazes de atingir a aceitação de todos os participantes de um possível discurso em relação à pretensão de verdade, o que ocorre da mesma forma em relação às outras pretensões." 238

A justeza de uma proposição não nasce, nessa linha, de uma afirmação absoluta e realizada com base na sua conformidade com um padrão pré-concebido de correção. A verdade, bem como a comprovação da realidade, são meras pretensões a serem alcançadas pelo esforço argumentativo de modo que se pode afirmar que um juízo acerca da verdade não é aferido em contraste com uma ordem objetiva pré-existente, antes, a validade de uma proposição é dada pelo discurso por meio do qual se constrói uma perspectiva de correção baseada na concordância.

De acordo com as lições do próprio Habermas "o universo moral perde a aparência ontológica de algo dado e é visto como algo construído." ${ }^{239} \mathrm{Ou}$ seja, a constatação daquilo que é bom ou ruim, certo ou errado e justo ou injusto não se dá a partir de uma análise de correspondência entre as ações e a realidade posta no mundo. A justeza de uma proposição é, antes de tudo, construída pelo consenso discursivo no qual a condição para a veracidade de um enunciado será o acordo potencial de todos aqueles que tomam parte no processo dialógico. ${ }^{240}$

\footnotetext{
${ }^{238}$ Ibid. p. 198.

239 "El universo moral pierde la aparencia ontologica de algo dado y se entrevé como algo construido". HABERMAS, Jürgen. Verdad y justificación. Trad. Pere Fabra e Luis Díez. Madrid: Trota, 2002. p. 290.

${ }^{240}$ Segundo Habermas: "Dentro del paradigma linguístico la verdad de los enunciados ya non puede ser concebida, em todo caso, más que como 'correspondencia com algo en el mundo'. De lo contrario deberíamos poder salirnos del lenguaje mediante el lenguaje. Ni siquiera podemos compara una expresión lingüística referida a una evidencia presuntamente definitiva com ningún trozo de realidad 'desnuda' y no interpretada, es decir, com um referente que eluda nuestro examen ineludiblemente linguístico. La verdad de um eneunciado parece que ya solo puede estar garantizada por la coherencia com otros enunciados." Ibid. p. 276. Alexy, por sua vez, ressalta da teoria de Habermas o fato de que a fundamentação pelo discurso surge como uma crítica à clássica teoria da verdade como correspondência. Segundo ele, o modelo aristotélico de que um enunciado é verdadeiro porque expressa a correspondência com um estado de coisas existentes é deficiente, sendo a teoria consensual de Habermas uma tentativa racional de exprimir a correção, uma vez
} 
Alexy, de seu turno, toma as lições de Habermas por supedâneo para construir sua teoria da argumentação jurídica, em especial, sua tese sobre a colisão entre os princípios, e, os direitos fundamentais. Segundo ele, o mérito de Habermas foi o de contribuir para esclarecer o conceito verdade na medida em que a argumentação racional revela-se como o mecanismo de comprovação das proposições verdadeiras ou corretas. In verbis: "A teoria consensual de Habermas aclarou pelo menos alguns aspectos do conceito de verdade, com a elaboração de regras fundamentais do procedimento de comprovação das proposições verdadeiras ou corretas."

Para Alexy, ainda, a contribuição de Habermas não se restringe, ainda, a evidenciar que a pretensão de verdade é auferida por um processo discursivo no qual se busca o consenso, uma vez que, também, propõe regras que garantem a higidez do diálogo racional. De nada adiantaria alegar que a validade de uma proposição depende do consenso extraído da argumentação se não se garantirem condições mínimas para que todos os participantes desse processo dialógico possam bem fundamentar suas asserções. ${ }^{242}$

Todavia, sem prejuízo de aprofundar as complexidades inerentes à teoria consensual, vale, aqui, sublinhar que para os adeptos das lições de Habermas a verdade, a correção e a justiça não seriam conhecidas aprioristicamente a partir de uma dada realidade, mas dependeriam de um esforço dialógico que demonstrasse um acordo sobre a validade material de uma proposição. A verdade não resultaria, assim, de uma análise de conformidade entre o enunciado e uma ordem objetiva prévia, pelo contrário, o que há no âmbito consensual é tão somente uma pretensão de verdade a ser aferida por meio do discurso cujo termo deve, necessariamente, propiciar um consenso sobre a correção de um enunciado, seja ele qual for.

Reconheça-se, outrossim, que essa busca da legitimidade pelo consenso está muito em voga nas letras jurídicas contemporâneas, surgindo como uma opção de justificação e de correção material do direito, tendo em vista a necessidade pós-positivista de que o ordenamento jurídico encontre um critério de conformidade material. Mais que

que a conclusão veraz de um diálogo se dá quando todos atribuem ao objeto o mesmo predicado. Cf. ALEXY, Robert. Teoria da Argumentação Jurídica: a teoria do discurso racional como a teoria da justificação jurídica. Trad. Zilda Silva. 2a ed. São Paulo: Landy Editora, 2005. p. 118 a 120.

${ }^{241}$ Ibid. p. 148.

${ }^{242}$ Alexy, ao analisar a teoria consensual de Habermas, aponta que o diálogo racional tem a pretensão de fundamentabilidade, ou seja, os envolvidos no discurso devem fundamentar sua argumentação. Segue-se a essa constatação o fato de que se deve garantir aos participantes do diálogo as condições necessárias para bem fundamentar suas proposições e, nesse sentido, Habermas alude a algumas regras que visam proporcionar condições para que o discurso se desenvolva regularmente. Cf. Ibid. 140 a 144. 
isso, a perspectiva da fundamentação pelo consenso é defendida, sobretudo, como uma alternativa racional de justificação de proposições normativas, uma vez que não se baseia em aspectos metafísicos ou em direitos inatos ao homem concebidos como uma ordem de valores externa à razão humana. ${ }^{243}$

Em todo caso, se adotada a teoria consensual, a legitimidade da atuação financeira do Estado a ser aferida, nos termos do art. 70 da $\mathrm{CF}$, pelos órgãos de controle interno e pelo controle externo, encontra uma identificação peculiar. Precisamente, a correção material das finanças públicas, a sua legitimidade, constatar-se-ia por meio de um procedimento dialógico que, baseado no consenso, atestaria a validade material da atuação financeira. Reconheça-se que esse método de apuração da legitimidade não verifica a conformidade das contas públicas com uma ordem de valor objetiva e externa à comunicabilidade social, mas, sim, apregoa que o juízo de correção decorre da consonância dos argumentos postos pelos partícipes do discurso.

Então, aquilo que seja a legitimidade da atuação financeira do Estado constróise a partir de um acordo, logrado mediante um mecanismo discursivo, que chancela a validade de determinada ação. Observe-se, entretanto, que a teoria do consenso surge como uma das muitas teorias existentes para se apurar a validade de uma proposição, não sendo, a toda evidência, imune a deficiências e a eventuais críticas.

A principal crítica à doutrina discursiva consensual é a que indaga sobre a possibilidade de chegar a um acordo. Simone Goyard-Fabre bem leciona:

"Entendamos que, nas sociedades industrializadas, um consenso relativo aos valores éticos, aos ideais políticos e mesmo aos interesses sociais já não existe. No lugar de um sistema de valores tradicionais, instalou-se o jogo da concorrência, irracional, pluralista, individualista, até mesmo egoísta e sempre implacável."244

\footnotetext{
${ }^{243}$ Confira, nesse sentido, as lições de Rogério Soares do Nascimento, para quem o pensamento de Habermas merece uma destacada atenção por se opor a uma justificação moral, transcendente e religiosa das ações humanas, objetivando, a partir do direito e da razão, assegurar a tolerância e o pluralismo. NASCIMENTO, Rogério Soares do. A ética do discurso como justificação dos Direitos Fundamentais na obra de Jürgen Habermas. In. TORRES, Ricardo Lobo (org.). Legitimação dos Direitos Humanos. $2^{\mathrm{a}}$ ed. Rio de Janeiro: Renovar, 2000. p. 521 a 523.

${ }^{244}$ GOYARD-FABRE, Simone. Os Princípios Filosóficos do Direito Político Moderno. Trad. Irene A. Partenot. São Paulo: Martins Fontes, 2002. p. 297.
} 
A autora focaliza sua crítica no fato de que o consenso ético, na complexa sociedade contemporânea, é praticamente impossível. Dessa maneira, toda a perspectiva do discurso e do esforço argumentativo torna-se um processo destinado à fatalidade, uma vez que o pretenso prestígio pluralidade dá lugar à asserções irracionais, egoístas e altamente subjetivas incapazes de compor com propriedade a validade efetiva de uma ordem jurídicopolítica.

Não se pode, ainda, deixar de esclarecer sobre os riscos sociais que a doutrina do consenso pode implicar. Não se olvide que a pretensão de correção e de verdade fica ao talante do processo dialógico, sempre passível de atualização e, consequentemente, hábil à formação de um novo consenso, o que pode significar a revisão da idéia de validade anteriormente existente. ${ }^{245}$ Ocorre, porém, que esse método não deixa de revelar uma grande insegurança, pois o que é tido por certo, bom e justo, pode, ao sabor de uma nova concepção discursiva, revelar-se incorreto, ruim e injusto.

Alerta, mais uma vez, Simone Goyard-Fabre:

"Recusar, junto com a universalidade unificadora da razão, as formas centralizadoras e as potências normativas do Estado não será correr o risco de condenar a vida social a seguir os movimentos e os impulsos da multidão, portanto, a afundar mais dia menos dia no caos? No limite, subordinar o direito político ao consenso social equivale à ausência de governo e de aparelho jurídico para regular a vida social: é uma utopia suicida." 246

Decididamente, construir a correção e a validade do que quer que seja pela via do consenso é, sem dúvida, um mecanismo periclitante. À medida em que se afasta a verdade de um critério objetivo alcançado pela razão e se coloca a correção como uma

\footnotetext{
${ }^{245}$ O próprio Habermas reconhece a mutabilidade das asserções morais. Segundo ele: "todas la normas reconocidas como validas, aun en el caso de estar bien fundamentadas, pueden ser complementadas mediante discursos de aplicación. Ahí puede poner-se de manifestó que determinadas circunstancias no previstas o nuevos hechos obligan a revisiones que vuelven a replantear cuestiones de fundamentación de la norma." HABERMAS, Jürgen. Verdad ... p.284.

${ }^{246}$ GOYARD-FABRE, Simone. Os Princípios... p. 485.
} 
pretensão alcançada pelo consenso, a anarquia e a insegurança surgem como consequência previsível. Nenhuma ordem jurídico-política cujo objetivo seja a paz social consegue conviver com a necessidade de um eterno discurso promotor do consenso, sobretudo porque vigoram na sociedade contemporânea preocupações dispersas e cambiantes que, por serem, não raro, inconciliáveis, acabariam em um jogo de concorrência interminável, deixando um vácuo de autoridade em prejuízo da pacificação social. Ou, ainda, se alcançado o consenso, inexiste óbice para que este possa conduzir a sociedade ao precipício, pois, prescindindo de padrões concretos de verdade, nada impede que o erro, a injustiça e o vício sejam tomados por pretensões válidas.

Nesses termos, data vênia, é preciso rechaçar a doutrina do consenso, não só pelos riscos à paz social, mas pela impossibilidade declarada de tal teoria em se chegar a um padrão objetivo de verdade. Em outras palavras, é preciso condenar o fato de que a doutrina do consenso concebe a verdade como uma mera pretensão, sendo ela construída única e exclusivamente pelo discurso. Ao contrário, a verdade não é construída, mas conhecida objetivamente. Aquilo que é bom, justo e correto não nasce, certamente, a partir do consenso social, antes, estas realidades são auferidas racionalmente pela razão humana.

O fato de que nem sempre é possível a um homem, singularmente considerado, conhecer o bem, a verdade e o justo e determinar-se de acordo com a correção, não significa que tais realidades não existam por si mesmas. Pode-se, em alguma medida, dizer que a argumentação e o discurso evidenciam a verdade existente, todavia, dizer que o discurso, obtendo o consenso, constrói uma perspectiva de correção e validade não parece acertado.

São preciosas, nesse contexto, as lições de Ana Paula de Barcellos ${ }^{247}$. Inicialmente, a autora consigna que a era contemporânea é marcada pelo relativismo moral, o que implica em alguma dificuldade em reconhecer o certo do errado, o justo do injusto, o bom do mau. Além disso, segundo ela, a aplicação do relativismo impede a formação de consensos morais, conferindo autoridade a uma opinião individual independentemente de uma verdade superior.

247 BARCELlOS, Ana Paula de. Constitucionalização das políticas públicas em matéria de direitos fundamentais: o controle político-social e o controle jurídico no espaço democrático. In: SARLET, Ingo Wolfang; TIMM, Luciano Benetti (orgs.). Direitos fundamentais. Orçamento e "reserva do possível”. Porto Alegre: Livraria do Advogado, 2008. p. 123. 
Entretanto, a autora prossegue afirmando que o relativismo moral não resiste ao confronto com a barbárie, a violência e a miséria, uma vez que em tais ambientes a convicção com padrões morais clássicos de certo/errado surge de maneira irresistível. Ana Paula de Barcellos apregoa, assim, que:

"o relativismo moral generalizado não é consistente, é possível concluir que há espaços em que pode haver padrões ou consensos morais: decisões certas em oposição a erradas, boas em oposição a más. Nessa espécie de ambiente, o fundamento da posição de um indivíduo sobre determinada matéria não consistirá apenas em sua própria opinião pessoal e relativa, mas poderá ser confrontada com esses padrões. (...). Trata-se de conferir maior valor a uma opinião porque, em determinado contexto, e, independentemente de seu emissor, nem todas as opiniões são equivalentes, indiferentes e igualmente relativas; existem parâmetros morais aplicáveis que permitem afirmar que determinadas posições são certas e outras erradas e, como parece natural, as posições certas têm valor superior às erradas."248

A questão que a autora coloca, portanto, não é a de uma construção discursiva que fundamente, pelo consenso, a correção do que quer que seja. Noutro giro, a noção de validade é apreendida com base em padrões morais clássicos de certo/errado por meio dos quais a opinião eventualmente equivocada resta fulminada. Nessa perspectiva de exclusão de proposições erradas, é possível concluir que inexiste discurso argumentativo: ou se adere à correção constatada objetivamente, ou a opinião imprecisa será fatalmente excluída do ambiente dialógico.

Erigindo-se a dicotomia de certo/errado como padrão de correção moral apto a excluir argumentos discursivos equivocados, o consenso argumentativo não pode se alçar como método de construção da validade. De outra sorte, os enunciados argumentativos são, na verdade, sopesados com uma ordem moral objetiva que confere adequação as

${ }^{248}$ Ibid. p. 124. 
opiniões ventiladas, de forma que o erro e a impropriedade não chegam a compor a esfera dialógica.

Nesse sentido, não se pode afirmar que a validade e a verdade são alcançadas pelo consenso, desprezando-se qualquer padrão de correção anterior. É preciso sublinhar que as proposições são contrastadas com uma ordem objetiva pré-existente que, a seu modo, pode ser conhecida pela razão. Não se deve, dessa maneira, negar ao homem a capacidade de conhecer o bem, a justiça e a verdade em oposição ao mal, à injustiça e à falsidade. É, sim, possível conhecer a realidade e avaliar as ações segundo parâmetros morais existentes que, por sua vez, permitem distinguir o certo e o errado.

Reconheça-se, entretanto, que aquilo que seja justo, moral, correto e bom não é, em alguns casos, facilmente definível. Embora se constate que o homem é capaz de reconhecer uma ordem objetiva de valores e julgar, de acordo com eles, o certo em oposição ao errado, é inegável que existem situações das mais complexas nas quais o juízo de correção ou incorreção não se mostra, à primeira vista, imediatamente definível.

Obviamente, há casos em que o juízo de correção se realiza facilmente: a reprovação da conduta ou do fato é de tal modo evidente que à razão humana só resta confirmar o erro. Mas, em certas hipóteses, o erro ou o acerto não são constatados desde logo, e, consequentemente, o juízo de correção não exsurge espontaneamente. Há, assim, situações limítrofes ou de difícil compreensão em que, não obstante haja um padrão correcional objetivo, não se pode fazer, prontamente, uma avaliação sobre a validade da questão posta sob exame.

Ocorre que, nesses casos de definição mais árdua, não se nega a eficácia da função discursiva consensual, entretanto, a argumentação não tem por escopo construir a verdade ou validade, como desponta na teoria de Habermas, mas sim o objetivo de evidenciar e encontrar uma verdade inteligível. O caráter dialógico cede, então, espaço ao método dialético. ${ }^{249}$

\footnotetext{
249 "La palabra dialéctica indica la lógica relativa al pensamiento en tanto está en movimiento. Lógica que considera al pensamiento no quieto, en proceso, cuyo término es lo verosímil, que supone la proximidad de la verdad. El fin, en tanto acabamiento, es llegar a una verdad. El pensamiento reposa e descansa, solo cuando llega a su cometido, a una verdad cierta. Si esto no se logra no se pode decir que está en reposo, sino que sigue de algún modo en búsqueda, en movimiento." HERNÁNDEZ DE LAMAS, Gabriela Beatriz. Dialéctica, Retórica y Educación: el método en el discurso pedagógico. In: LAMAS, Félix Adolfo. La Dialéctica Clásica: la lógica de la investigación. Buenos Aires: Instituto de Estudios Filosóficos Santo Tomás de Aquino, 2008. p. 168.
} 
Como aduz Michel Villey, amparado em Aristóteles, é natural que a arte jurídica valha-se do "método dialético, que procede por confronto de exemplos e de opiniões contraditórias, porque cada opinião reflete um aspecto da realidade." 250 De modo algum a dialética estabelece a realidade e não constrói, portanto, um padrão moral por si mesma. O mecanismo dialético permite que o embate de posições contrárias evidencie todos os aspectos de uma dada realidade de modo a esclarecer a verdade existente.

Pela dialética acha-se a exata proporção das coisas dadas. Assim, o esforço argumentativo revela, nos casos mais tormentosos, nuances da realidade que, de outro modo, ficariam ocultadas, franqueando a possibilidade de extrair uma avaliação mais adequada acerca da correção e da validade de determinada situação. Em outros termos, o método dialético permite uma síntese das posições opostas, sendo tal conclusão não um acordo consensual, mas um julgamento objetivo de certo ou errado sobre o caso apresentado.

Vislumbra-se, entretanto, que o método dialético só se faz necessário na perspectiva de indeterminação. O fato de que o padrão de correção é algo objetivo e inteligível leva à conclusão de que é possível extrair, prontamente, um juízo de correção e incorreção. Somente nas hipóteses mais complexas e limítrofes nas quais, desde logo, não se aponta um juízo de validade é que o esforço dialético coloca-se como reclame para evidenciar a verdade.

Recorda Michel Bastit que:

"A indeterminação que se manifesta ali (na disputa discursiva) não é simplesmente uma questão de procedimento ou de organização do discurso. A organização indeterminada do discurso dialético resulta da indeterminação da matéria sujeita ao discurso. Em outros termos, a indeterminação não é somente relativa ao discurso, mas daquilo que se fala no discurso. É a indeterminação da coisa em si mesma." 251

\footnotetext{
${ }^{250}$ VILLEY, Michel. O direito e os direitos humanos. Trad. Maria Ermantina de Almeida Prado Galvão. São Paulo: Martins Fontes, 2007. p. 51.

251 'L'indetermination que si manifeste ici n'est pás simplement une question de procédure ou 'organisarion du discours. L'organisation indetérminée du discours dialectique résulte de l'indetermination de la matière
} 
A dialética surge, portanto, na indeterminação, na disputa e na controvérsia do tema posto em análise. Afinal, somente com o estabelecimento da divergência é que se faz necessário um esforço argumentativo para se chegar a uma conclusão veraz. De outro modo, havendo de imediato e sem dificuldade a constatação da validade ou invalidade do caso em exame não há que se falar em mecanismo dialético, pois este método só se desenvolve sobre o terreno da indeterminação. ${ }^{252}$

Assim, é imperioso reafirmar que o homem é hábil a avaliar a correção de algo sem se socorrer do discurso e do dialoguismo; apenas nas situações controvertidas é que se mostra forçoso o expediente dialético. Na maioria dos casos, a razão humana, evidenciando um parâmetro moral objetivo de correção, consegue avaliar as proposições e emitir um julgamento sobre a justiça, a verdade e o acerto do evento em exame.

Nesse sentido, a aferição da legitimidade preconizada pelo art. 70 da CF de 1988 pode ser realizada de imediato e sem a necessidade de buscar um consenso acerca da validade da questão sindicada. A justiça, o bem, em síntese, a correção material da atividade financeira do Estado pode ser apreciada com base em padrões morais objetivos e perfeitamente inteligíveis pelo homem - que atestam o acerto ou desacerto na condução das finanças públicas.

Tão somente nas hipóteses mais complexas e limítrofes das quais emana a controvérsia é que se faz preciso um esforço dialético, todavia, esse processo discursivo não almeja construir a correção, mas evidenciá-la, buscando nos argumentos apresentados a veracidade sobre o caso a ser avaliado.

qui est le sujet du discours. En d'autres termes, l'indetermination est non seulemente celle du discours mais celle de ce dont parle le discours. Elle est l'indétermination de la chose même." BASTIT, Michel. Dialectique et Métaphysique. In: LAMAS, Félix Adolfo. La Dialéctica Clásica: la lógica de la investigación. Buenos Aires: Instituto de Estudios Filosóficos Santo Tomás de Aquino, 2008. p. 168.

252 "La dialectique se développe sur le terrain de l'indetéterminé" Ibid. p. 49. 


\section{III - FISCALIZAÇÃO FINANCEIRA QUANTO À LEGITIMIDADE.}

\section{HISTÓRICO.}

O controle financeiro da legitimidade não encontra qualquer precedente na história constitucional brasileira. ${ }^{253}$ Antes de 1988, o exame das contas públicas limitavase à apuração da legalidade formal, inexistindo mecanismos jurídicos que possibilitassem um controle mais profundo e substancial. O Tribunal de Contas, sobretudo, carecia de qualquer competência para sindicar os aspectos éticos e materiais da gestão financeira.

Os juristas pátrios não pouparam críticas a esse modelo de controle de contas. Seabra Fagundes, em 1955, alertava: "O côntrole de contas, como hoje se exerce, é puramente formal, o que vale dizer nada significa em relação à legitimidade e à moralidade da aplicação das dotações orçamentárias. Resulta apenas no coonestamento de tudo quanto se faz." ${ }^{254}$ Adiante, o autor focaliza sua análise sobre a atuação da Corte de Contas, indicando: “A jurisdição do Tribunal de Contas e o rito de seu funcionamento exigem reforma urgente e ampla, capaz de retirar o controle financeiro da mera formalidade". 255

Caio Tácito, por sua vez, empreende uma análise sobre histórico constitucional do Tribunal de Contas até 1988 e conclui:

"A diligente atuação do Tribunal de Contas se defrontava, porém, com dois óbices históricos. De uma parte, sua atividade de controle se exercia, dominantemente, no tocante aos atos consumados ou em curso de execução e, de outra

\footnotetext{
${ }^{253}$ Cf. TORRES, Ricardo Lobo. Tratado ... p. 509.

${ }^{254}$ FAGUNDES, Miguel Seabra. Reformas essenciais ao aperfeiçoamento das instituições políticas. Revista de Direito Administrativo, Rio de Janeiro, vol. 43, jan/mar, 1956. p. 12.

${ }^{255}$ Ibid., p. 13.
} 
parte, se concentrava no exame formal dos atos e contratos submetidos a registro ou controle." 256

As críticas elencadas apontam para o fato de que o cotejo da gestão financeira estatal em face de requisitos puramente formais não era hábil para coibir situações que, embora hígidas sob o prisma da lei, revelavam um conteúdo de patente desonestidade e injustiça.

O novo regime constitucional de fiscalização financeira não poderia conviver com tamanha deficiência. Seria preciso ir além e sobrepujar o mero contraste formal, dotando os órgãos de controle com faculdades que lhes permitissem verificar a justiça e a moralidade da atuação financeira do Estado.

Nessa esteira, o constituinte de 1988 franqueou aos órgãos de controle a possibilidade de sindicar a legitimidade - e, também, a economicidade - dos atos de gestão financeira, restando indubitável a possibilidade de se exercer uma fiscalização mais incisiva e capaz de superar os aspectos do legalismo estrito. Hodiernamente, não só o Legislativo, mas também o Tribunal de Contas está habilitado a apurar a correção material da gestão dos recursos públicos. A esse propósito leciona Régis de Oliveira:

"Mas quando fala em legitimidade, para interpretarmos essa palavra, quer nos parecer que fica o Tribunal de Contas agora não só habilitado a analisar o contraste formal da norma inferior com a superior, como também o próprio destino desse dinheiro; se aquilo realmente atende ao interesse público, ou seja, contrastar e reduzir nesse sentido $o$ âmbito que se denomina de mérito administrativo. $O$ tribunal pode devassar a intimidade do ato para saber se, realmente, aquele ato está atendendo ao interesse público." 257

256 TÁCITO, Caio. A moralidade administrativa e a nova lei do Tribunal de Contas da União. Revista de Direito Administrativo, Rio de Janeiro, vol. 190. out/nov, 1992. p. 49.

${ }^{257}$ OLIVEIRA, Régis Fernandes. Fiscalização Financeira... p. 214. 
As lições do autor são elucidativas. Apreende-se delas que controle de legitimidade permite um contraste mais substancial das contas públicas, pois abre o campo para que o Tribunal de Contas possa apurar se a atuação financeira do Estado ateve-se aos ditames do interesse público. Em última análise, o controle externo dilata-se para aferir se atuação financeira do Estado foi condizente com a consecução da justiça e a promoção do bem comum.

Por outro lado, Régis de Oliveira revela um particular interessante. Segundo ele, a sindicância da legitimidade assume contornos tão profundos que possibilitaria, até mesmo, o enfrentamento do mérito administrativo.

Nesse sentido, essa novidade constitucional - a fiscalização quanto à legitimidade - não deixa de levantar alguns questionamentos. Não se pode deixar de indagar sobre os limites da atuação dos órgãos de controle, verificando em que medida lhes é autorizado a rever os critérios de conveniência e oportunidade afeitos à competência decisória do administrador público. 


\section{PROBLEMÁtiCA: A FISCALIZAÇÃO DA LEGITIMIDAdE E A INVASÃO DO MÉRITO ADMINISTRATIVO.}

Sindicar a legitimidade da atuação financeira do Estado conduz, inegavelmente, ao enfrentamento da discricionariedade na gestão dos recursos públicos.

Registre-se, preliminarmente, que a discricionariedade está longe de ser um poder arbitrário. As escolhas administrativas não podem ser temerárias, irrefletidas e despreocupadas com a efetiva realização do bem comum. Nesse sentido, a margem de liberdade que decorre da competência discricionária é, antes de tudo, um campo para escolhas legítimas. $^{258}$

Nas lições de Celso Antonio Bandeira de Mello " $a$ discrição nasce precisamente do propósito normativo de que só se tome a providência excelente, e não a providência sofrível e eventualmente ruim". ${ }^{259}$ E caso a solução excelente não seja a eleita pelo agente público, "haverá pura e simplesmente violação da regra de Direito, o que enseja correção jurisdicional, dado que terá havido vício de legitimidade." 260

Assim, o alvedrio subjetivo do administrador público não é inteiramente livre para decidir qual medida deve ser adotada. A solução eleita deve, invariavelmente, atender certos reclames de correção, probidade e aderência à satisfação do interesse público, pois a liberdade de opção só tem sentido se, ao final, a atuação administrativa concluir pela solução justa.

Compreende-se, desse modo, que a correção do exercício discricionário não se resume à observância de uma legalidade de contornos extrínsecos, que considera, tão somente, a autorização para escolher uma, dentre as várias condutas possíveis. É preciso ir ao cerne, ao âmago da atuação discricionária e investigar se a escolha feita pelo agente está

\footnotetext{
${ }^{258}$ Bem anota Juarez Freitas que: “O Estado Constitucional, numa de suas mais expressivas dimensões, pode ser traduzido como o Estado das escolhas administrativas legítimas. Assim considerado, nele não se admite a discricionariedade pura, inátil, sem limites." FREITAS, Juarez. Discricionariedade Administrativa e o Direito Fundamental à Boa Administração Pública. $2^{\mathrm{a}}$ ed. São Paulo: Malheiros, 2009. p. 09.

${ }^{259}$ BANDEIRA DE MELLO, Celso Antonio. Discricionariedade e Controle Jurisdicional. $2^{\mathrm{a}}$ ed., $9^{\mathrm{a}}$ tr. São Paulo: Malheiros, 2002. p. 35.

${ }^{260}$ Ibid. p. 37.
} 
em conformidade com certos princípios cujo conteúdo ético constrange a decisão administrativa a eleger sempre a melhor providência.

Nessa linha, Gustavo Binenbojm ${ }^{261}$ observa a emergência dos princípios no controle da discricionariedade. Ele atesta que os princípios constitucionais gerais, como o da igualdade e, ainda, os princípios setoriais da Administração Pública, consagrados no caput do art. 37 da CF, são instrumentos de conformação das escolhas discricionárias, reduzindo, sensivelmente, o âmbito de liberdade do administrador.

Pois bem, essa adesão da Administração aos princípios demonstra que a liberdade decisória não é um campo estranho ao Direito. Evidentemente, não se está a advogar a conformação da discricionariedade como uma legalidade acanhada e meramente formal. $O$ que se defende é que as escolhas efetuadas pelos agentes públicos sejam consentâneas com os valores recolhidos no ordenamento jurídico que, por sua vez, conduzem a decisão discricionária ao termo justo.

Fala-se, portanto, que as escolhas discricionárias devem obedecer a um padrão de legitimidade. Juarez Freitas leciona com precisão:

"Legítima será, então, a liberdade exercida em conformidade com as regras e, acima delas, com os exigentes princípios $e$ objetivos fundamentais da Constituição. Fora daí, cristalizar-se-á, em maior ou menor grau, a desprezível e abominável arbitrariedade por ação ou omissão." 262

Adiante, desenvolve o raciocínio para afirmar:

"as escolhas administrativas serão legítimas se -e somente se - forem sistematicamente eficazes, motivadas, proporcionais, transparentes, imparciais, respeitadoras da

${ }^{261}$ Cf. BINENBOJM, Gustavo. Uma Teoria ... p. 208 a 210.

${ }^{262}$ FREITAS, Juarez. Discricionariedade... p. 16. 
participação social, da moralidade pública e da plena responsabilidade."263

Em resumo, Juarez Freitas professa que a discricionariedade administrativa encontra limite na legitimidade, pois o mero atendimento da legalidade não é suficiente para conferir correção às escolhas administrativas. Nesse sentido, foi preciso estabelecer um critério - a legitimidade - cuja substância não se confunde, tão somente, com a positividade das leis, mas vai além e apregoa um dever de boa administração pelo qual os agentes estatais se comprometem a observar os princípios reitores do Poder Público, elegendo, sempre, a solução ótima diante da situação apresentada. ${ }^{264}$

Logo, para verificar se determinada ação é legítima será preciso examinar a justeza e a correção que norteou a opção estatal. Caso a margem decisória do administrador fuja aos padrões de moralidade e justiça, não se poderá afirmar a higidez da sua conduta. O exame de legitimidade acaba, então, por incidir diretamente nas escolhas provenientes da competência discricionária, possibilitando, assim, o controle do chamado mérito administrativo. Aponta Clóvis de Carvalho Junior que:

“Não há como não se permitir a revisão do Ato Administrativo por defeito de mérito se se toma em consideração o conceito de legitimidade. (...) Enfim, não se pode impedir o juiz de examinar o ato administrativo em seus componentes para que o Ato, além de formal e legalmente perfeito possa ser considerado justo" 265

No particular do controle financeiro, adverte-se que a fiscalização quanto à legitimidade leva ao controle do mérito. Régis de Oliveira é enfático nesse sentido, afirmando que com a aferição da legitimidade: "Passa a ser admitido o exame do mérito.",266

\footnotetext{
${ }^{263}$ Ibid. p. 23 e 24.

${ }^{264}$ Ibid. p. 22.

${ }^{265}$ CARVALHO JUNIOR, Clóvis de. Mérito do Ato Administrativo. Tese de Doutorado - USP. São Paulo: edição do autor, 1978. p. 381.

266 OLIVEIRA, Régis Fernandes. Curso... p. 391.
} 
O autor fala com acerto em exame de mérito, pois não se trata, simplesmente, de sindicar formalidades externas da atuação discricionária, tais como a forma e a competência. De fato, o mérito diz respeito ao núcleo do ato discricionário e se relaciona diretamente com o binômio "conveniência e oportunidade". A rigor, o mérito consiste na eleição de uma medida, dentre várias possíveis, mediante a apreciação das circunstâncias fáticas e segundo um juízo prévio de conveniência e oportunidade. ${ }^{267}$ E é justamente sobre esse binômio "conveniência e oportunidade" que incide a sindicância da legitimidade.

Na clássica lição de Seabra Fagundes, o mérito: "Compreende os aspectos, nem sempre de fácil percepção, atinentes ao acerto, à justiça, utilidade, eqüidade, razoabilidade, etc. de cada procedimento administrativo. Esses aspectos, muitos autores resumem no binômio: oportunidade e conveniência." 268

Nota-se que esse juízo de conveniência e oportunidade não é eticamente neutro ou desprovido de qualquer comprometimento com o bem comum. Muito pelo contrário, como aduz Seabra Fagundes, ele corresponde a uma compreensão sobre a justiça, a utilidade e a eqüidade da medida administrativa adotada, sendo assim fator determinante para decisão do administrador.

Nesse diapasão, a sindicância da legitimidade indaga se ponderação pessoal do administrador resultou, em concreto, na adoção de uma medida conveniente e oportuna, perquirindo não só acerca da legalidade ou ilegalidade, mas também se a decisão tomada é boa ou ruim, justa ou injusta, útil ou inútil, enfim, se a decisão administrativa pautou-se pelos princípios de boa administração e o desiderato de satisfazer as necessidades públicas.

Caso contrário, se verificada a ilegitimidade o mérito restará viciado e a discrição administrativa terá servido não para alcançar a melhor solução, mas sim aquela sofrível e despreocupada com a efetiva promoção do interesse público.

Entretanto, avulta na doutrina jurídica uma preocupação em preservar o mérito administrativo de qualquer forma de controle exterior à Administração. Propõe-se, então, a insindicabilidade do mérito administrativo, em especial, pelo Poder Judiciário.

\footnotetext{
267 “Se, por um lado, os autores evitam o problema da definição do mérito do ato administrativo, limitandose a circunscrever-lhe a área, por outro lado, não há divergência quando se trata de agrupar os infinitos matizes em que ele se desdobra, traduzidos na fórmula sintética expressa pelo binômio oportunidadeconveniência. Na prática, 'in concreto', o mérito apresenta-se como a ponderação pessoal da autoridade administrativa sobre determinados fatos, que a levam a decidir num sentido ou noutro e, até mesmo, de nada decidir." CRETELLA JÚNIOR, José. Tratado de Direito Administrativo. V. II. $2^{\mathrm{a}}$ ed. Rio de Janeiro: Forense, 2002. p. 179.

${ }^{268}$ FAGUNDES, Miguel Seabra. O contrôle dos atos administrativos pelo Poder Judiciário. $4^{\mathrm{a}}$ ed. Rio de Janeiro: Forense, 1967. p. 149 e 150.
} 
Os administrativistas procuram salvaguardar o juízo de conveniência e oportunidade da apreciação judicial, alegando ser este um campo privativo da Administração Pública. Teme-se que o Poder Judiciário possa interferir indevidamente nas escolhas administrativas em clara afronta às competências exclusivas da Administração, de modo que restaria vedado ao juiz subtrair o ofício do administrador.

A esse propósito lecionava Seabra Fagundes: "O mérito é de atribuição exclusiva do Poder Executivo e o Poder Judiciário, nêle penetrando 'faria obra de administrador, violando, dessarte, o princípio da separação e independência dos podêres.",269

Mais recentemente, Celso Antonio Bandeira de Mello ${ }^{270}$, Juarez Freitas ${ }^{271}$ e José Eduardo Cardozo ${ }^{272}$, dentre outros, são tributários da teoria que proíbe ao judiciário a possibilidade de aferir o mérito administrativo. ${ }^{273}$

Há que se reconhecer, todavia, que o mérito não pode servir de refúgio para acobertar toda sorte de desvios e incorreções. ${ }^{274}$ Deve sempre remanescer a preocupação de preservar a missão institucional da Administração em face de ingerências do Poder Judiciário, não obstante, é inadmissível que a conduta administrativa abusiva, arbitrária e inconseqüente escape ao controle, a despeito de se salvaguardar o mérito administrativo.

Notadamente, a discrição administrativa pode basear-se na irreflexão e em interesses escusos e, fatalmente, essa fundamentação tortuosa corrompe toda a higidez do mérito administrativo. Arremata, nesse sentido, Diogo Moreira Neto que, reproduzindo a doutrina italiana, aduz: "O exercício vicioso da discricionariedade, comprometendo o mérito, é, por isso, a causa do 'vício de mérito". ${ }^{275}$ Assim, as más escolhas da Administração acabam por perverter o mérito e fazem com que a decisão administrativa se

\footnotetext{
${ }^{269}$ FAGUNDES, Miguel Seabra. O contrôle ... p.150.

${ }^{270}$ BANDEIRA DE MELLO, Celso Antonio. Discricionariedade... p. 40.

${ }^{271}$ FREITAS, Juarez. Discricionariedade... p. 34.

${ }^{272}$ CARDOZO, José Eduardo Martins. A Discricionariedade e o Estado de Direito. In: GARCIA, Emerson (org). Discricionariedade Administrativa. Rio de Janeiro: Lumen Juris, 2005. p. 56 e 57

${ }^{273}$ Vale esclarecer que os autores citados pressupõem que o mérito compreende a eleição de uma medida válida perante o Direito, sendo, portanto, inconcebível sua sindicabilidade. Nas lições de Bandeira de Mello e Cardozo, o mérito é a liberdade para escolher entre duas ou mais soluções admissíveis, tendo em conta o exato atendimento da finalidade legal (BANDEIRA DE MELLO, Celso Antonio. Discricionariedade... p. 38. e CARDOZO, José Eduardo Martins. A Discricionariedade... p. 57). Juarez de Freitas aduz igualmente, pregando que o mérito é insindicável, mas o abuso e o "demérito" são passíveis de revisão pelo Judiciário. (FREITAS, Juarez. Discricionariedade... p. 34 e 48). Logo, eles admitem que o Judiciário controle os abusos e incorreções das escolhas administrativas, sem, contudo, revisar as opções válidas e justas compreendidas por ele como o mérito administrativo.

${ }^{274}$ Cf. DI PIETRO, Maria Sylvia Zanella. Discricionariedade... p. 130. "O que não é aceitável é usar o vocábulo mérito como escudo à atuação judicial."

${ }^{275}$ MOREIRA NETO, Diogo de Figueiredo. Legitimidade... p. 32.
} 
enverede por um campo que, seguramente, não é o da legitimidade. Logo, a sindicabilidade do mérito administrativo é perfeitamente defensável, pois só assim será possível verificar eventuais despropósitos que, uma vez constatados, devem ensejar a consequente correção. $^{276}$

O Judiciário, por sua vez, não tem se furtado em corrigir eventuais abusos cometidos sob o pretexto do agir discricionário. Como bem relata José dos Santos Carvalho Filho: "Encontram-se nos repertórios de jurisprudência vários julgados que, diante de casos concretos, validaram ou invalidaram condutas administrativas que, em princípio, foram produzidas sob a égide do poder discricionário."277

Ocorre, mais recentemente, uma tendência do Judiciário em aprofundar a sindicância do mérito administrativo, investigando diretamente as razões de conveniência e oportunidade que orientaram a decisão administrativa. É paradigmático, nesse sentido, o pronunciamento do STJ em sede de Recurso Especial: “O Poder Judiciário não mais se limita em examinar os aspectos extrínsecos da administração, pois pode analisar, ainda, as razões de conveniência e oportunidade, uma vez que essas razões devem observar critérios de razoabilidade e moralidade."278

Assim, a toda evidência, a jurisdição pátria não mais admite a consecução de abusos e incorreções, a despeito de salvaguardar o mérito administrativo. O exercício da competência discricionária, em especial o juízo de conveniência e oportunidade que ela pressupõe, não pode se afastar de certos reclames morais que conferem legitimidade à discrição administrativa. Havendo qualquer impropriedade no uso da margem de liberdade que se defere ao administrador público, o Judiciário deverá censurar o ato expedido, sob pena de se instaurar um regime de tolerância com erros e injustiças.

No plano do controle financeiro o mesmo raciocínio deve ser aplicado, até porque a Constituição Federal é expressa ao afirmar, no art. 70, que a fiscalização financeira deve examinar, não só a legalidade, mas também a legitimidade. Essa dicção constitucional é de extrema relevância porque mesmo aqueles que entendem o controle judicial como restrito à legalidade, advogam que o controle financeiro pode ir além, invadindo a esfera do mérito. É o caso de José de Ribamar Caldas Furtado:

\footnotetext{
276 “Faz-se, ineliminável, vez por todas, a sindicabilidade do 'demérito’ administrativo.” FREITAS, Juarez. Discricionariedade... p. 44.

${ }^{277}$ CARVALHO FILHO, José dos Santos. A Discricionariedade: análise de seu delineamento jurídico. In: GARCIA, Emerson (coord). Discricionariedade Administrativa. Rio de Janeiro: Lumen Juris, 2005. p. 37. ${ }^{278}$ BRASIL. Superior Tribunal de Justiça. Resp. 429.570/GO. Rel. Min. Eliana Calmon. j. 22.03. 2004.
} 
"Se o controle jurisdicional se restringe apenas ao exame da legalidade do ato administrativo (controle jurídicoadministrativo), o sistema de fiscalização previsto no art. 70, caput, da Carta da República (controle políticoadministrativo) vai muito além, podendo apreciar, inclusive, o mérito do ato. E não se trata de afronta ao princípio da separação dos poderes. Eis que é missão constitucional do Poder Legislativo examinar sob o aspecto da legitimidade, a atuação do Poder executivo e dos demais poderes, tendo, nesse mister, o auxílio do Tribunal de Contas."279

De outro modo, admitindo-se o controle judicial da legitimidade, com muito maior razão deve-se aceitar o controle financeiro desse aspecto. Eis que os entes responsáveis pelo controle financeiro externo - o Legislativo e o Tribunal de Contas estão constitucionalmente habilitados para sindicar a legitimidade da gestão dos recursos públicos de modo que as escolhas da Administração não escapam ao exame e à possível revisão. Não há, portanto, falar-se em preservação do mérito administrativo quando a conduta do gestor público revelar-se viciada, abusiva e despreocupada com a efetiva realização da justiça.

O Tribunal de Contas, em especial, pode exercer um papel mais profícuo na apuração da legitimidade. Primeiro porque não compõe os quadros da Administração, podendo atuar com maior desenvoltura e independência. Ademais, compete-lhe fiscalizar e julgar os gestores de bens e recursos públicos, o que permite à Corte de Contas debruçar-se sobre os pormenores da conduta administrativa para evidenciar, com maior eficácia, qualquer tipo de incorreção.

Cite-se, exemplificativamente, a atuação do TCE de São Paulo quando da análise da legitimidade na concessão de "ajuda de custo" aos agentes políticos. Embora os agentes políticos possam realizar, discricionariamente, gastos pessoais à custa dos cofres públicos, o Tribunal entende que tais despesas não podem ser suportadas em todo e qualquer caso. A posição da Corte de Contas evidencia que licitude desses encargos não se

${ }^{279}$ FURTADO, José de Ribamar Caldas. Elementos de Direito Financeiro. Belo Horizonte: Fórum, 2009. p. 332. 
circunscreve à comprovação de requisitos legais (prévia dotação, empenho, comprovação do gasto, etc.). Exige-se, também, um juízo de legitimidade pelo qual essas despesas devem ser módicas, razoáveis e perfeitamente justificáveis, tendo em vista a promoção do interesse público e o ofício do agente que lhes deu causa. ${ }^{280}$

Nesses casos, o Tribunal de Contas avalia o espectro de conveniência e oportunidade dos agentes, pois nem todas as despesas pessoais que realizam, em nome e à custa da Administração, merecem o financiamento pelo erário público. Havendo qualquer desvio de finalidade ou justificativas desarrazoadas para o dispêndio, o agente que o promoveu receberá a censura por parte da Corte de Contas.

Nota-se, assim, que a fiscalização da legitimidade enseja ao Tribunal de Contas a possibilidade de realizar um exame acurado das escolhas dos gestores públicos. No entanto, embora haja uma habilitação constitucional para contraditar o mérito, é preciso indagar sobre a extensão e os limites da atuação sindicante da Corte de Contas.

Poderia, por exemplo, o Tribunal de Contas afirmar ser ilegítima a construção de um estádio para competições esportivas internacionais, tendo em vista a situação calamitosa da saúde pública? Caberia a esse órgão avaliar a legitimidade de um programa educacional que prefere direcionar mais recursos para a educação básica, em vez de investir no ensino pré-escolar?

É muito provável que se possa citar inúmeros casos nos quais se discuta a legitimidade das opções derivadas da discricionariedade, entretanto, em muitos deles restará patente que a atuação do Tribunal de Contas não pode ir tão longe. Não se concebe que esse órgão do controle externo possa chegar ao ponto de suplantar as decisões políticas do Governo.

Conforme as lições de Francesc Vallès Vives: "as atividades dos órgãos de controle externo nunca podem substituir o poder discricionário da Administração para eleger suas prioridades e âmbitos de atuação, que por sua própria essência sempre devem permanecer na mão dos representantes políticos." 281

\footnotetext{
${ }^{280}$ Cf. BRASIL. Tribunal de Contas do Estado de São Paulo. Manual Básico - Remuneração dos Agentes Políticos Municipais. 2a ed. atual, 2007. p. 27 e 28.

${ }^{281}$ VIVES, Francesc Vallès. El controle... p. 168. "la actividad de los órganos de control externo nunca puede sustituir a la potestad discrecional da la Administración para elegir sus prioridades y àmbitos de actuación, que por su propia esencia siempre deberá permanecer en manos de los representantes políticos y los responsables gubernamentales."
} 
Nessa esteira, embora o controle de legitimidade permita ao Tribunal de Contas apreciar as escolhas discricionárias, é preciso garantir que os órgãos de controle não devassem os critérios de conveniência e oportunidade relativos às prioridades e ao âmbito da atuação financeira estatal. Não se cogita, portanto, que a Corte de Contas possa minar as prerrogativas dos governantes, ditando-lhes a direção política da atividade financeira do Estado.

Assim, é preciso encontrar um equilíbrio entre o controle da legitimidade e a preservação da discricionariedade em matéria financeira. Essa compatibilização importa, sem dúvida, na constatação de que a atividade financeira do Estado comporta dois tipos de atividade discricionária: a) uma política de contornos mais amplos determinante de diretrizes gerais atinentes às prioridades e ao âmbito da gestão financeira; e b) uma meramente administrativa com margem de liberdade mais restrita cuja missão é concretizar os objetivos fixados pela atuação política.

Logo, existindo duas esferas discricionárias, é correto contemplar a existência de dois regimes de controle financeiro externo. Conforme se trate da discricionariedade política ou administrativa, haverá, respectivamente, um controle de características mais genéricas e fluidas, garantido, assim, maior liberdade para atuação financeira; e um controle mais rigoroso e estrito que se destina a coibir qualquer vício de legitimidade quando da materialização concreta dos escopos gerais ditados pelos representantes do povo.

\subsection{Discricionariedade política e discricionariedade administrativa.}

Os administrativistas, com muito acerto, além de apontar para a existência das três clássicas funções do Estado - legislativa, executiva e judiciária - distinguem, paralelamente, outras duas funções estatais, quais sejam, a função de governo e a função administrativa. $^{282}$

${ }^{282}$ Cf. MEIRELLES, Hely Lopes. Direito... p. 65 e 66. DI PIETRO, Maria Sylvia Zanella. Direito Administrativo. $22^{\mathrm{a}}$ ed. São Paulo: Atlas, 2009. p. 51. BANDEIRA DE MELLO, Celso Antônio. Curso... p. 34 e 35 . 
A distinção entre a função de governo e a função administrativa apenas constata o fato de que a Administração e o Governo cumprem papéis institucionais peculiares, atuando cada qual dentro de um quadro jurídico próprio.

Ao Governo compete traçar a direção política do Estado, indicando os fins públicos e as diretrizes para alcançá-lo. Cabe a ele, nitidamente, uma tarefa de impulso, de iniciativa e de direção da vida estatal. A Administração, de seu turno, exerce uma missão instrumental em relação ao Governo, pois compete a ela executar e concretizar os objetivos políticos encampados na esfera governamental. Em feliz metáfora de Antonio Amorth: "O Governo é a cabeça, a Administração os braços". ${ }^{283}$

Todavia, cumpre ressaltar, conforme a doutrina de Odete Medauar ${ }^{284}$, que Administração e Governo coexistem de modo separado, mas sem que haja fronteiras rígidas entre eles. Exige-se, na verdade, uma simbiose salutar entre função de governo e função administrativa o que impede a configuração de um aparato administrativo excessivamente tecnicista, ou, em sentido diverso, exageradamente ideológico. De outra parte, um relacionamento equilibrado entre Administração e Governo evita que o direcionamento político padeça de qualquer despreparo técnico e de irracionalidade no comando da gestão pública. $^{285}$

Mas interessa sublinhar que Administração e Governo possuem enquadramentos jurídicos diversos, razão pela qual é possível concebê-los de maneira apartada. A diferença que mais se evidencia reside na questão da responsabilidade dos agentes do Governo e dos agentes da Administração. Os agentes políticos não assumem, em regra, responsabilidade profissional pela execução de seus atos. Reserva-se para eles uma responsabilidade constitucional e política. É o caso, por exemplo, dos crimes de responsabilidade do Chefe do Executivo previsto no art. 85 da CF. Os agentes da

283 "il Governo è la testa, l'Amministrazione le bracia". AMORTH, Antonio. Atti del Governo. In: AMORTH, Antonio. Scritti Giuridici: 1931-1939. V I. Milano: Giuffrè Editore, 1999. p. 182.

${ }^{284}$ MEDAUAR, Odete. O Direito.... p. 136 a 144.

${ }^{285}$ É indeclinável citar a experiência italiana que, trabalhando com a tese da separação entre Governo e Administração, operou uma nova distribuição de funções e cargos públicos precisando-lhes a competência e a responsabilidade, segundo uma distinção clara entre política e gestão. Nesse sentido, Odete Medauar sublinha que cabe ao direito administrativo disciplinar o relacionamento entre Governo e Administração (Cf. MEDAUAR, Odete. O Direito Administrativo...p. 139 e 140.). García de Enterría, embora crítico da separação entre Governo e Administração, dá conta, ao destacar o caso italiano, que a divisão entre política e gestão visa combater o aparelhamento partidário da Administração e as consequências nefastas que dele resultam. (GARCÍA DE ENTERRÍA, Eduardo. Democracia, Jueces... p. 132 e 133). 
Administração, de seu turno, sujeitam-se à responsabilidade profissional e legal pelos atos que nessa condição praticarem. ${ }^{286}$

Outra peculiaridade está no âmbito jurídico em que Administração e Governo se movem. Do ponto de vista formal, a função governo se desenvolve sob o enfoque da liberdade ou discricionariedade máxima, ao contrário da função administrativa, vinculada, por excelência, às normas legais e constitucionais. ${ }^{287}$

Isso não significa que o Governo atua à margem da lei e da Constituição, muito menos que inexista uma esfera discricionária para a Administração. O que ocorre, no entanto, é que "a discricionariedade do ato político é maior do que a discricionariedade do ato administrativo, em geral. Ambas, porém, têm limitações." 288

Há muito os autores italianos ${ }^{289}$ já esclareceram esse pormenor. A atividade de governo é essencialmente livre no sentido de que o ordenamento não lhe precisa um comportamento pré-determinado diante de uma dada situação. De fato, as normas podem balizar e limitar o Governo sem lhe ditar, contudo, uma ação determinada e concreta. Cretella Júnior ${ }^{290}$ esclarece que a discricionariedade política está desvinculada de formas apriorísticas; antes, reveste-se de uma benéfica plasticidade o que lhe permite, dadas as mais variadas conjunturas, indicar quais são finalidades públicas e as diretrizes adequadas para alcançá-las.

A função administrativa é, por outro lado, essencialmente vinculada, submetida que está a um regime mais rígido de legalidade. Se a função de governo não comporta a pré-definição de comportamentos, a atuação administrativa pode e, muitas vezes o é, determinada, em concreto, pelo ordenamento. Vale aqui repetir o célebre adágio dos administrativistas, segundo o qual aos particulares é lícito fazer tudo o que a lei não proíbe; para a Administração, ao contrário, só é permitido fazer aquilo que a lei autoriza ou determina.

\footnotetext{
${ }^{286}$ Cf. MEIRELLES, Hely Lopes. Direito... p. 66.

${ }^{287}$ Jorge Miranda aduz que a função de governo insere-se no contexto de uma função política cujas características são: definição primária e global do interesse público; interpretação dos fins do Estado e as escolhas dos meios para atingi-los com liberdade ou discricionariedade máxima (MIRANDA, Jorge. Manual de Direito Constitucional. Tomo V. $2^{\mathrm{a}}$ ed. Coimbra: Coimbra Ed., 2005. p. 23). No tocante à função administrativa, Celso Antonio advoga que ela é desempenhada mediante comportamentos infralegais e infraconstitucionais (BANDEIRA DE MELLO, Celso Antônio. Curso... p.34 e 35.).

${ }^{288}$ CRETELLA JÚNIOR, José. Tratado de Direito... p.122.

${ }^{289}$ Cf. AMORTH, Antonio. Scritti ... p. 183; e, MORTATI, Costantino. L'ordinamento del Governo nel Nuovo Diritto Pubblico Italiano. Milano: Giuffré, 2000. p. 17 e 18.

${ }^{290}$ CRETELLA JÚNIOR, José. Tratado ... p. 123.
} 
É evidente, contudo, que a Administração goza, em inúmeros casos, de faculdades discricionárias, entretanto, a discricionariedade administrativa não se confunde com a discricionariedade política. A primeira recai sobre situações fáticas individualizadas, concretas e momentâneas, requerendo do agente público a eleição de uma medida que vá ao encontro da realização do interesse público. A segunda não leva em consideração um fato singular, mas se atém a situações mais globalizadas, perquirindo, dentre as mais variadas conjecturas, qual finalidade deve ser encampada.

Assim, enquanto a discricionariedade administrativa busca a finalidade do interesse público, a discricionariedade política é ela própria determinante da finalidade. ${ }^{291}$ Há, na esfera política, como se deduz das lições de Eduardo Appio ${ }^{292}$, uma contraposição entre interesses públicos na medida em que os agentes responsáveis pelo Governo elegem, dentre várias finalidades possíveis, a que se lhes apresenta mais atrativa à realização do bem comum, definindo, portanto, aquilo que seja o interesse público.

Consequentemente, se cabe ao Governo, mediante discricionariedade política, definir as finalidades públicas e os meios de persegui-la, precisando assim o chamado interesse público, caberá à Administração, conforme o caso, usar da discricionariedade para encontrar, na situação singular, a solução que melhor satisfaça aquele interesse.

Desse modo, é possível afirmar que a distinção entre discricionariedade política e administrativa não se encontra apenas no grau de liberdade que se extrai de cada uma. A diferença reside, sobretudo, no âmbito em que ambas recaem. A discricionariedade de que dispõe o Governo presta-se a definir os escopos do Estado e a eleger as diretrizes gerais pelos quais eles serão alcançados. Em via paralela, mas não oposta, a discricionariedade administrativa diz respeito à gestão quotidiana conduzida pela Administração Pública e sua função não é determinar finalidades e objetivos, mas buscar, na situação fática e singular, a solução que melhor satisfaça o interesse público.

Ressalte-se, por fim, que essas funções de governo e de administração são perfeitamente observáveis no campo da atividade financeira do Estado de modo que a condução das finanças públicas comporta a existência de uma discricionariedade

291 “Invece per l'attivitá di governo una semplice predeterminazione di fine non è possible, poiché è essa stessa che, per sua natura, è determinante del fine." MORTATI, Costantino. L'ordinamento del Governo... p. 18.

${ }^{292}$ Assevera o autor: "Cumpre assinalar, desde logo, a importante distinção entre controle judicial dos atos administrativos e políticos, na medida em que enquanto os primeiros são tradicionalmente marcados pela oposição interesse público versus interesse individual, os últimos são marcados pela contraposição entre interesses públicos." APPIO, Eduardo. Controle Judicial das Políticas Públicas no Brasil. Curitiba: Juruá, 2005. p. 110. 
nitidamente política, extraída da esfera governamental, e uma discricionariedade meramente administrativa procedente dos atos de gestão operados pela Administração.

\subsection{Discricionariedade em matéria financeira e o regime orçamentário.}

Para vislumbrar as feições da discricionariedade em matéria financeira, seja ela política ou administrativa, é preciso atentar ao exercício das funções de governo e de administração no tocante às finanças públicas.

O ponto de partida é, sem dúvida, a Constituição. Não possível precisar as peculiaridades das atividades de governo e de administração sem se debruçar sobre a Constituição, que, em última análise, define os aspectos fundamentais da atribuição do poder estatal. Jorge Miranda afirma, com propriedade, que a função política, da qual decorre a função de governo, é dependente da forma e do sistema governo adotado pela Constituição. In verbis:

"o específico da função política reside na sua incindibilidade total da forma e do sistema de governo. Se os órgãos administrativos e jurisdicionais se aproximam, mais ou menos, por toda a parte, já as instituições políticas são apenas aquelas que a Constituição cria - e a Constituição tem, necessariamente, de as criar e regular sob pena de sua inefectividade - e, em cada caso, em sintonia com a forma e o sistema de Governo constitucionalmente consagrados." 293

Essa lição de Jorge Miranda reforça a consideração de que a Constituição é a Carta das Competências. Está entre as tarefas mais elementares do constituinte organizar estrutura do Estado e estabelecer os Poderes e órgãos que o compõe, definindo, inclusive, suas respectivas atribuições. Nesse sentido, somente a partir da disciplina constitucional é

${ }^{293}$ MIRANDA, Jorge. Manual de Direito ... p. 28. 
que se torna possível identificar os agentes responsáveis pela condução política do Estado, bem como os métodos pelos quais ela se exterioriza.

No âmbito financeiro, a análise da Constituição de 1988 revela que essa função política, ou de governo, é realizada mediante um enquadramento institucional preciso, qual seja, o campo orçamentário.

Sérgio Assoni Filho ${ }^{294}$ afirma que o orçamento público é o espelho da atividade financeira do Estado, uma vez que nele estão consignados, não somente as receitas e as despesas, mas também os planos e programas da atuação governamental. De fato, historicamente, o orçamento é um instrumento consagrado do planejamento e da racionalização das finanças públicas tanto que, já no século XIX, o Conde Cavour, artífice da unificação italiana, afirmava: "Dê-me um orçamento bem feito e eu lhe direi como o país é governado." 295

A atividade financeira é, portanto, indissociável da figura do orçamento, pois ele é a sua expressão formal, é seu veículo organizativo e estruturante. Por meio dele o Estado estabelece seu plano de gastos, seu planejamento financeiro e sua atuação econômica de modo que a função de governo relativa à condução das finanças públicas só pode ser vislumbrada mediante um regime orçamentário concreto. Nesses termos, a Lei Maior de 1988 não se furtou em regulamentar o processo de orçamentação estatal. Nota-se que a Constituição precisa as competências dos Poderes quanto à gênese dos orçamentos públicos, determinando, em alguma medida, o conteúdo do orçamento prospectivo. Assim, a discricionariedade da função de governo no tocante às finanças públicas só pode ser identificada a partir da disciplina constitucional que orienta a elaboração, apreciação, aprovação e execução do orçamento público.

Ressalte-se, antes de tudo, que a existência de uma discricionariedade política é inerente à figura dos orçamentos. Não obstante as mais variadas teorias sobre a natureza jurídica do orçamento, este é, essencialmente, uma peça contábil na qual são definidas as despesas estatais e as receitas que haverão de custeá-las. Por óbvio, a determinação dessas receitas e despesas não é realizada ao acaso, mas envolve um

\footnotetext{
${ }^{294}$ ASSONI FILHO, Sérgio. Transparência Fiscal e Democracia. Porto Alegre:Nuria Fabris, 2009. p. 80.

295 Cf. PÉREZ ROYO, Fernando. Derecho Financiero y Tributario: parte general. 20 a ed. Cizur Menor: Civitas, 2010. p. 483.
} 
processo decisório nitidamente político do qual se extrai um juízo sobre os fins e os meios abarcados pela esfera governamental. ${ }^{296}$

Vem à baila a oportuna doutrina de Aliomar Baleeiro: "Em todos os tempos e lugares, a escolha do objetivo da despesa pública envolve um ato político, que também se funda em critérios políticos, isto é nas idéias, convicções, aspirações e interesses revelados no entrechoque dos detentores dos grupos detentores do poder." 297

O viés político fica patente na elaboração dos orçamentos públicos, uma vez que o desiderato dos governantes é fator preponderante na fixação das receitas e das despesas. Mais que isso, todo o planejamento estatal arquitetado pelo orçamento se dá em razão do direcionamento político proposto pelo Governo. Destarte, a definição de metas, planos, programas e prioridades está à mercê das concepções políticas dominantes, de tal sorte que os agentes do governo operam a distribuição dos recursos do erário da maneira que entendem mais adequada para concretizar as necessidades individuais e sociais. ${ }^{298}$

Reconheça-se, nessa esteira, que a alocação de recursos na peça orçamentária se dá com a mais larga discricionariedade, uma vez que os atores responsáveis pela elaboração do orçamento decidem como, quando, quanto e em que empregar os recursos públicos.

Resta evidente, contudo, que essa discricionariedade não é ilimitada. Há de se reconhecer a existência de toda uma sistemática constitucional que acaba por reduzir a liberdade dos responsáveis pela gênese orçamentária. Cite-se, exemplificativamente, a existência de patamares mínimos de gastos em alguns serviços públicos, certas vinculações de receitas e todo um plexo de direitos fundamentais que exigem do Estado um mínimo de recursos para implementá-los. ${ }^{299}$

\footnotetext{
${ }^{296}$ Ramos afirma com propriedade que o planejamento governamental e o orçamento público envolvem a seleção de fins e meios para alcançar as metas desejadas e afirma, textualmente, que: "Fazer escolhas orçamentárias relacionadas com emprego de fins e meios envolve especificamente a tomada de decisões políticas que alocam escassos recursos econômicos entre os setores público e privado da sociedade." RAMOS, Naimar M. Planejamento e Política Financeira do Governo. Brasília: Esaf, 1982. p. 65.

${ }^{297}$ BALEEIRO, Aliomar. Uma introdução... p. 78.

${ }^{298}$ MATIAS-PEREIRA, José. Finanças Públicas: a política orçamentária no Brasil. $4^{\mathrm{a}}$ ed. São Paulo: Atlas, 2009. p. 267 a 273.

${ }^{299} \mathrm{~A}$ respeito da limitação da discricionariedade quanto à elaboração dos orçamentos, confira CATAPANI, Márcio Ferro. A discricionariedade do Poder Executivo na elaboração do projeto de lei orçamentária anual. p. 245 a 266. Especificamente quanto à necessidade do orçamento contemplar a efetividade de direitos fundamentais veja ASSONI FILHO, Sérgio. Controle de Constitucionalidade da lei orçamentária. p. 21 a 40. Ambos In: CONTI, José Mauricio e SCAFF, Fernando Facury (coord.) Orçamentos Públicos e Direito Financeiro. São Paulo:RT, 2011.
} 
Essas limitações, em todo caso, não desnaturam a discricionariedade política própria dos orçamentos públicos, pois, ainda que se possa, em alguns casos, pré-definir os destinos das receitas, sempre existirá uma margem de liberdade quanto às prioridades, aos meios e às formas de empregar os recursos públicos. Tudo fica a depender da política governamental adotada. Se há, por exemplo, uma constrição para prestigiar determinado direito fundamental, é bem verdade que há uma esfera discricionária quanto ao modo de seu adimplemento. In casu, para satisfazer o direito à moradia pode-se eleger, orçamentariamente, empregar os recursos em financiamentos imobiliários, ou, na construção de casas populares, ou no subsídio de aluguéis, ou, ainda, em todas essas ações conjuntamente. Havendo, em todas as hipóteses, margem de liberdade para quantificar o montante dos recursos alocados.

Como se nota, portanto, sobressai uma elevada discricionariedade em relação à previsão orçamentária, sendo tal margem de liberdade orientada por um forte apelo político. ${ }^{300}$ Não é demais consignar as lições de Régis de Oliveira, para quem:

"A decisão de gastar é, fundamentalmente, política. O administrador elabora um plano de ação, descreve-o no orçamento, aponta os meios disponíveis para o seu atendimento e efetua o gasto. A decisão política já vem inserta no documento solene de previsão de despesas. Dependendo das convicções políticas, religiosas, sociais, ideológicas, o governo elabora seu plano de gasto. Dai a variação que pode existir de governo para governo, inclusive diante das necessidades emergentes. "301

Como bem aponta o autor, esse espectro decisório acerca do destino dos recursos públicos pode fundar-se nas mais variadas convicções. É certo que a orientação governamental dominante elege não somente as finalidades genéricas do gasto, como também escolhe, orçamentariamente, os planos e programas que haverão de atender tais

\footnotetext{
300 Poder-se-ia afirmar que não existe nenhuma discricionariedade quanto às obrigações de caráter continuado, uma vez que devem figurar nos orçamentos enquanto perdurar sua exigibilidade. Entretanto, é preciso notar que houve discricionariedade quando da assunção inicial dessas obrigações. Ou seja, houve um espectro político decisório quanto aos termos e a possibilidade de assumir, ou não, uma obrigação que se protrai por mais de um exercício financeiro.

${ }^{301}$ OLIVEIRA, Régis Fernandes. Curso... p. 252.
} 
escopos. Logo, é possível afirmar que a liberdade dos agentes políticos quanto à previsão orçamentária classifica-se, notadamente, no âmbito da discricionariedade política, uma vez que seu exercício envolve um juízo da esfera de Governo sobre os fins e os meios necessários à consecução do bem comum. ${ }^{302}$

Desse modo, sem prejuízo de se reconhecer uma discricionariedade política quanto à orçamentação financeira do Estado, é preciso esclarecer, igualmente, que a Constituição disciplina todo o processo de elaboração e apreciação orçamentária, indicando, para tal fim, quem são os atores responsáveis pela definição política das previsões consignadas no orçamento público.

Conforme o art. 84, XXIII, c.c. o art. 165 da CF de 1988, o Chefe do Executivo possui competência privativa na elaboração do projeto de lei orçamentária, deferindo-lhe tal prerrogativa a possibilidade de definir os contornos basilares da destinação dos recursos públicos, segundo critérios políticos de conveniência e oportunidade. $^{303}$

Ao Executivo cabe esboçar, discricionariamente, todo o conteúdo da lei orçamentária futura. No particular do regime orçamentário pátrio, ele projetará não somente o elenco das despesas e o seu respectivo financiamento, mas também todo o planejamento financeiro e econômico do Estado. Ocorre que a CF de 1988 estabelece um regime orçamentário sistêmico baseado no planejamento estratégico. Para tanto, a orçamentação brasileira está assentada em três grandes peças, a saber: a lei orçamentária anual, a lei diretrizes orçamentárias e o plano plurianual. ${ }^{304}$ Desse modo, o destino das verbas públicas é previsto em sintonia com a consecução de planos de longo prazo, programas, metas, prioridades e diretrizes, revelando que a elaboração da proposta orçamentária concebida pelo Executivo insere-se dentro de um contexto maior, no qual sobressai o planejamento e a orientação estratégica da atividade financeira do Estado.

\footnotetext{
302 "Para que possa cumprir suas finalidades, a política orçamentária necessita que sejam adotadas muitas decisões políticas, tendo em vista o amplo elenco de alternativas que se encontram à disposição das autoridades governamentais, referentes à destinação dos recursos públicos." MATIAS-PEREIRA, José. Finanças Públicas... p. 277.

${ }^{303}$ Esclareça-se que os Poderes e órgãos dotados de autonomia financeira, tais como o Judiciário, o Ministério Público e a Defensoria, elaboram suas próprias propostas orçamentárias (arts. $99, \S 1^{\circ} ; 127, \S 3^{\circ} \mathrm{e}$ $134, \S 2^{\circ}$ da CF). Essas propostas são encaminhadas ao Executivo que consolida o projeto de lei orçamentária e o apresenta ao Parlamento. Todavia, a proposta orçamentária realizada "motu próprio" pelo Executivo é a que contempla o planejamento econômico-financeiro do Estado e os gastos que haverão de satisfazer, diretamente, as necessidades mais sensíveis dos indivíduos.

${ }^{304}$ Arts. 84, XXIII, e 165 da CF de 1988.
} 
De outra sorte, concentrar a elaboração do projeto orçamentário nas mãos do Executivo tem uma razão de ser. Precipuamente, é o Poder Executivo quem assume a prestação dos serviços públicos e o fornecimento de utilidades materiais fruíveis pelos cidadãos, competindo-lhe, ainda, promover a arrecadação das receitas necessárias ao custeio da atuação estatal. Nada mais lógico, portanto, que deferir a ele a prerrogativa de formar o projeto orçamentário por meio do qual lhe será possível traçar a configuração elementar da gestão administrativa, indicando não só as ações que pretende realizar, mas também o seu respectivo custeio. ${ }^{305}$

Entretanto, o projeto orçamentário confeccionado pelo Executivo só adquire eficácia jurídica quando regularmente aprovado pelo Poder Legislativo. Consoante os arts. 48, II, e 166 da CF de 1988, o Congresso Nacional apreciará e aprovará o projeto orçamentário encaminhado pelo Executivo. Mas, além do caráter de eficácia jurídica que essa aprovação confere ao orçamento, vale sublinhar o aspecto político que Legislativo assume nesse particular. Ao aprovar o projeto orçamentário, o Parlamento dá seu assentimento à orientação financeira pré-fixada pelo Executivo e participa de uma maneira acentuada no direcionamento político do Estado. Conforme a doutrina de Luís Cabral de Moncada: "A aprovação parlamentar da lei de orçamento representa sempre a adesão a um ato de direção política fundamental, em que o Parlamento se vê associado à tarefa de corporizar, aprovando o orçamento, um 'impulso' político autônomo, assumindo ou não as opções do Governo, ao mais alto nível de decisão dos órgãos do Estado" 306

No caso brasileiro, a participação do Legislativo na aprovação do orçamento não se resume com o mero assentir ao projeto apresentado pelo Executivo. É de se notar que o Parlamento protagoniza um papel ativo quanto à direção política das finanças estatais, pois se concede aos parlamentares a faculdade de emendar o projeto orçamentário encaminhado pelo Executivo. Nos termos do art. 166, § $2^{\circ}$, da CF de 1988, os membros do Legislativo podem, com algumas restrições, emendar o projeto de lei orçamentária,

\footnotetext{
${ }^{305}$ Mauricio Conti agrega outras razões pelas quais a iniciativa de leis orçamentárias é da competência privativa do Executivo. Aduz o autor: "informações fundamentais para a elaboração e execução do orçamento estão também sob o comando do Poder Executivo, como é o caso da arrecadação, essencialmente concentrada no âmbito federal, no Ministério da Fazenda. Sendo assim, é natural e coerente que a elaboração da proposta orçamentária fique a cargo do Poder Executivo, cabendo-lhe por conseguinte, a iniciativa legislativa nesta matéria". CONTI, José Mauricio. Iniciativa Legislativa em matéria financeira. In: CONTI, José Mauricio e SKAFF, Fernando Facury (coord). Orçamentos Públicos e Direito Financeiro. São Paulo: RT, 2011. p. 292.

${ }^{306}$ MONCADA, Luís S. Cabral. Perspectivas do novo direito orçamental português. In: MONCADA, Luís S. Cabral. Estudos de Direito Público. Coimbra: Coimbra Editora, 2001. p. 92 e 93.
} 
influenciando, dessa maneira, o direcionamento político que há de se configurar no orçamento público.

A realidade demonstra, todavia, que a projeção orçamentária elaborada pelo Poder Executivo acaba prevalecendo, porque sempre remanesce a estrutura básica do projeto original. Ocorre que as possibilidades de alteração do projeto são muito restritas e a praxis do Parlamento, segundo Marcos José Mendes ${ }^{307}$, consiste em elevar a estimativa de receita e utilizar desse superávit contábil para introduzir novas despesas, deixando imune de emendas a previsão consubstanciada pelo Executivo.

Mas em que pese a mitigação da influência parlamentar na emenda do projeto orçamentário, o fato é que a Constituição atribui ao Executivo e ao Legislativo a formulação do orçamento público. Cabe a eles determinar qual será a orientação política das finanças estatais, decidindo com ampla margem de liberdade o destino das receitas públicas. Nesse sentido, compete-lhes fixar quanto, como, quando e em que os recursos do erário serão empregados de modo que se extrai dessa atribuição uma clara discricionariedade política em matéria orçamentária.

O orçamento resulta, desse modo, de uma síntese decisória compartilhada entre o Executivo e o Legislativo. Tudo que nele se insere é fruto de deliberações políticas efetivadas sob o impulso da mais larga discricionariedade, mas cujo escopo fundamental é eleger, dentre as mais variadas opções, quais são as finalidades públicas e quais os meios adequados para concretizá-las.

Porém, não se pode deixar de destacar que o papel de discricionariedade política do Executivo vai além. Uma vez aprovado o orçamento e estando em curso sua execução, o Chefe do Executivo tem a prerrogativa de manejar, discricionariamente, mecanismos de flexibilidade orçamentária. ${ }^{308}$

As constantes mutações das conjunturas econômicas e sociais reclamam a possibilidade de se alterar o orçamento em execução, pois, dificilmente, as condições nas

\footnotetext{
${ }^{307}$ Em resumo, as emendas parlamentares não podem atingir um extenso rol de despesas consideradas obrigatórias e a parte modificável só poderá ser alterada se a emenda guardar pertinência com a programação orçamentária, sendo os recursos utilizados provenientes da anulação de despesas. (art. $166, \S \S 3^{\circ}$ e $4^{\circ}$ da $\mathrm{CF}$ de 1988). Quanto à práxis do Legislativo confira: MENDES, Marcos José. Sistema orçamentário brasileiro: planejamento, equilíbrio fiscal e qualidade do gasto público. Série Texto para discussão $\mathrm{n}^{\circ} 39$. Brasília: Senado Federal, 2008. p. 16.

${ }^{308}$ Coforme atesta Mauricio Conti: "O processo de execução orçamentária é dotado de mecanismos que permitem a adaptação da Lei Orçamentária às alterações surgidas ao longo do exercício financeiro, mantendo os objetivos e os programas fixados pelo poder público, em consonância com o princípio da flexibilidade.” CONTI, José Mauricio. A autonomia...p 96.
} 
quais se deu a elaboração e a aprovação do orçamento se mantêm inalteradas. Bem aponta José Afonso da Silva que: "nem sempre as previsões podem captar todas as condições vigentes à época da execução, e não é possível programar de forma que a execução se ajuste completamente às previsões." 309

Sobretudo no contexto globalizado, na qual as relações de todos os gêneros sofrem com os mais diversos matizes, as necessidades sociais e individuais estão sujeitas às mais profundas alterações. Essas transformações, uma vez ocorridas, podem se confrontar com os critérios políticos que orientaram previsão inicial do orçamento, indicando que a lei de meios, tal como foi aprovada, não se mostra hábil para atender aos novos anseios da coletividade.

Assim, se ao Poder Executivo competia elaborar o projeto orçamentário, segundo critérios de conveniência política, poderá ele, diante da mudança de conjuntura, propor a alteração do orçamento em curso para melhor prover o bem estar geral.

Para tanto, o Poder Executivo pode lançar mão dos chamados créditos adicionais. Na síntese lapidar de José Mauricio Conti:

“Alterações na lei orçamentária operam-se por meio de leis que abrem créditos adicionais, conforme previsão nos arts. 40 a 46 da Lei 4320/1964, que admitem os créditos suplementares: destinados ao reforço de dotação orçamentária já existente; os créditos especiais para as despesas não contempladas por dotação orçamentária específica; e os créditos extraordinários, para as despesas urgentes e imprevistas." 310

Os créditos adicionais são, dessa maneira, instrumentos de modificação do orçamento públicos vigente. Nos termos do art. 167, V, a Constituição admite a alteração do orçamento desde que haja autorização legislativa e a indicação dos recursos correspondentes. Com larga discricionariedade, o Poder Executivo pode, então, valer-se

\footnotetext{
${ }^{309}$ SILVA, José Afonso da. Orçamento-programa...p. 310.

${ }^{310}$ CONTI, José Mauricio. Iniciativa Legislativa... p. 294.
} 
desse expediente e propor ao Legislativo projeto de lei para incluir novas despesas (créditos especiais) ou reforçar as já existentes (créditos suplementares).

Caso específico é o que se refere aos créditos extraordinários, que são veiculados por meio de medida provisória e visam atender despesas urgentes e imprevisíveis. ${ }^{311}$ Embora se advogue a existência de uma ampla liberdade quanto à configuração dos requisitos de relevância e urgência - autorizadores da expedição da medida provisória -, o $\mathrm{STF}^{312}$ já se posicionou na linha de restringir a liberdade do Executivo quanto à abertura de créditos extraordinários, sendo possível incluir dotações urgentes e imprevisíveis apenas nas hipóteses arroladas pela Constituição, quais sejam, no caso de guerra, comoção interna e calamidade pública.

Em todo caso, os créditos adicionais supõem que o Poder Executivo, no curso da execução orçamentária, apresente um projeto de lei ou uma medida provisória tendente a modificar o orçamento vigente. Há, porém, outras hipóteses nas quais a possibilidade de alteração do orçamento já estava prevista quando da sua aprovação inicial. Ou seja, não é necessário que o Executivo introduza um projeto de lei para a mudança do orçamento, pois o próprio orçamento, desde o início, autorizava a sua futura modificação.

É muito comum adotar aquilo que se chama de "margem de remanejamento". Conforme a previsão do art. $165, \S 8^{\circ}$ da CF, é possível que o Legislativo autorize, desde logo e até certo limite, o Executivo a suplementar as dotações orçamentárias, sem a abertura de créditos suplementares. Nesse particular, os recursos da suplementação adviriam de uma reserva financeira. Outro mecanismo semelhante é o da "transposição" ou "transferência", também, previsto constitucionalmente no art. 167, VI, e pelo qual o Executivo, gozando de autorização legislativa prévia, poderia desguarnecer determinada categoria de despesa e alocar os recursos em outra categoria existente. ${ }^{313}$

Todos esses mecanismos de flexibilidade, que permitem a alteração do orçamento, são manejados com larga discricionariedade pelo Executivo e se prestam, a toda evidência, a suprir as distorções constatadas entre o orçamento originalmente aprovado e os reclames sociais mais contemporâneos. Mas o que se deve ressaltar é que a discricionariedade política que move a elaboração do projeto orçamentário, move, também, os créditos adicionais e os métodos de remanejamento e transposição. Não é sem um juízo sobre os fins e os meios da gestão financeira que o Poder Executivo propõe e realiza a

${ }^{311}$ Cf. arts. 62 e $167, \S 3^{\circ}$ da CF de 1988.

${ }^{312}$ BRASIL. Supremo Tribunal Federal. ADI 4048/DF-MC. Min. Gilmar Mendes. j. 22.08.2008.

${ }^{313}$ Cf. CONTI, José Mauricio. A autonomia...p 97 e 98. 
alteração do orçamento. Se a programação financeira do Estado, tal como aprovada, se revela incapaz de satisfazer as necessidades públicas, nada mais coerente do que permitir a sua modificação.

Ainda no campo orçamentário, a discricionariedade política do Poder Executivo destaca-se, outrossim, quando da efetivação do plano de gastos consubstanciado no orçamento público. O Poder Executivo está habilitado, não só a modificar a lei orçamentária vigente, como também a deixar de cumprir alguns de seus comandos. Esse fato decorre diretamente da natureza jurídica do orçamento pátrio que defere a possibilidade de contingenciar certas dotações orçamentárias. ${ }^{314}$

Em alguma medida, as despesas fixadas na lei orçamentária não são de realização compulsória, ou seja, o executor do orçamento tem a prerrogativa de não efetuar as despesas previstas. Nesse sentido, Rodrigo Oliveira Faria ${ }^{315}$ pondera que a lei orçamentária comporta uma pluralidade normativa, existindo um âmbito de vinculação quanto aos fins a que ela se destina, e um campo meramente autorizativo que diz respeito aos meios usados para atingir as finalidades prescritas. Mais precisamente, há uma obrigatoriedade em alcançar determinados objetivos estratégicos, fiscais e programáticos, e, por outro lado, a lei orçamentária comporta no tocante às dotações um duplo comando: autorização e proibição. Autorização que faculta a realização de despesas; e proibição que veda a assunção de gastos fora dos limites orçamentários previstos.

Não haveria, conforme a exegese do autor citado, uma obrigação em efetivar certas despesas públicas, uma vez que as dotações previstas não compelem a realização do gasto, apenas o autorizam, e proíbem, tão somente, a utilização de recursos acima do teto indicado. Inexistiria, de outro modo, a necessidade de exaurir as dotações orçamentárias, pois não há nenhuma lógica em determinar o esgotamento dos recursos disponíveis, em sendo possível obter o mesmo resultado com custos menores. ${ }^{316}$

A visão de Rodrigo Faria não deixa de ser acertada. Ora, as receitas que financiam as dotações são, originalmente, estimadas, e não raro pode ocorrer que a receita arrecada seja menor que a estimativa prevista, fazendo-se necessário contingenciar

\footnotetext{
314 Registre-se, contudo, que nem todas as dotações podem ser contingenciadas. O fenômeno do contingenciamento tem tratamento explícito no art. $9^{\circ}$ da LRF sob a denominação de "limitação de empenho". Consoante apregoa o $\S 2^{\circ}$ do artigo, não serão objeto do contingenciamento as despesas relativas às obrigações legais e constitucionais do ente, bem como as que se referem ao serviço da dívida e as ressalvadas pela lei de diretrizes orçamentárias.

${ }^{315}$ FARIA, Rodrigo Oliveira de. Natureza Jurídica do Orçamento e Flexibilidade Orçamentária. Dissertação de mestrado. Faculdade de Direito da USP. São Paulo: edição do autor, 2009. p. 262 e 263.

${ }^{316}$ Cf. Ibid. p. 168.
} 
algumas despesas. Sobretudo diante de finalidades vinculadas, como o atendimento de metas fiscais de observância peremptória, é dever indeclinável do Executivo deixar de realizar algumas despesas em prestígio ao equilíbrio das contas públicas e às normas de responsabilidade fiscal. ${ }^{317}$

Reforça, nesse aspecto, o fato de que o desequilíbrio fiscal entre receitas e despesas encontra forte oposição no ordenamento jurídico que, de seu turno, não se furta em estabelecer sanções ao gasto público irresponsável. ${ }^{318}$ Uma visão sistemática da LRF, em especial a acurada leitura dos arts. 15 e 16, confirma a irregularidade da despesa realizada ao arrepio das metas de superávit fiscal, restando, indubitável, a possibilidade de se proceder ao contingenciamento de gastos quando a efetivação da despesa possa acarretar prejuízo às metas estabelecidas.

Resulta, portanto, que o contingenciamento revela-se um expediente corriqueiro na execução orçamentária. Assim, é certo vislumbrar uma esfera discricionária quanto à escolha das dotações prejudicadas com a limitação de empenho. Rodrigo Faria esclarece que "há espaço para certa discricionariedade do administrador público, diante da necessidade de seleção dos programas e objetivos a serem privilegiados"319, e afirma adiante que: "havendo necessidade de limitação de empenho, as unidades orçamentárias deverão proceder à seleção de programas a serem privilegiados, em face das circunstâncias concretas existentes, de forma a procurar garantir o maior nível possível de exequibilidade dos programas governamentais, em face das restrições fiscais havidas., 320

Essa discricionariedade importa, sem dúvida, na formulação de um juízo político em que pesam os anseios sociais e as convicções dos atores responsáveis pelo contingenciamento. São eles que, segundo critérios de conveniência política, elegem as prioridades e selecionam os programas que entendem prementes e indispensáveis à satisfação do interesse público por eles definido. O contingenciamento de algumas

\footnotetext{
${ }^{317}$ Corroboram, na mesma linha, as lições de Maurício Conti ao discorrer sobre o contingenciamento: "Assim, ainda que prevista a dotação na Lei Orçamentária, e incluindo o valor na programação financeira, a realização da despesa poderá não ser autorizada, tendo em vista a limitação de empenho decorrente de insuficiência na arrecadação de receitas ou cumprimento das metas estabelecidas." CONTI. José Maurício. A autonomia... p. 96.

318 As despesas em descompasso com as autorizações da lei orçamentária ou que infrinjam as metas previstas na lei de diretrizes orçamentárias acarretam sanções, podendo, inclusive, ensejar crimes de responsabilidade aos agentes políticos responsáveis, nos termos da Lei 10.079 de 1950. Cf. FARIA, Rodrigo Oliveira de. Natureza Jurídica do Orçamento... p. 234 a 247.

${ }^{319}$ Ibid. p. 197

${ }^{320}$ Ibid. p. 198.
} 
dotações, não se faz, portanto, sem uma considerável dosagem de discricionariedade política.

Assim, não se pode deixar de reconhecer que a precariedade vinculativa das dotações orçamentárias, decorrente da própria natureza jurídica do orçamento, importa no exercício de uma prerrogativa discricionária nitidamente política pela qual o Executivo escolhe prioridades e, mediante um juízo sobre os fins públicos, contingencia as despesas que entende menos indispensáveis à concretização do bem comum.

Desse modo, a discricionariedade política no campo orçamentário sobressai não só no tocante à faculdade de elencar as despesas e as receitas, os programas, planos, metas e suas posteriores modificações, mas também no que se refere à prerrogativa de selecionar quais dotações haverão de ser contingenciadas.

Entretanto, uma vez aprovada e vigente a lei orçamentária, é preciso reconhecer, igualmente, que dela deriva uma discricionariedade puramente administrativa. Grosso modo, a lei orçamentária fixa o destino das verbas públicas, entretanto, a previsão dos gastos públicos no orçamento reclama, muitas vezes, uma integração discricionária por parte do gestor diretamente responsável pela execução orçamentária.

É imperioso ressaltar que o Brasil adota a técnica do orçamento-programa, ou seja, as leis orçamentárias destinam os recursos públicos, vinculando-os à realização de diversos programas de governo. ${ }^{321}$ Como bem destaca José Afonso da Silva:

"o orçamento-programa não é apenas uma peça financeira, $e ́$, antes de tudo, um instrumento de execução de planos e projetos de realização de obras e serviços, visando ao desenvolvimento da comunidade. É um documento em que se designam os recursos de trabalho e financeiros destinados à execução dos programas, subprogramas e projetos de execução da ação governamental". 322

321 "A classificação por programa é exigência legal no Brasil, desde a promulgação da Lei n. 4320, de 1964” SILVA, José Afonso da. Orçamento-programa... p. 64.

${ }^{322}$ Ibid. p. 41. 
Assim sendo, a destinação dos recursos financeiros pela via do orçamentoprograma não se faz pela simples indicação do setor em que serão alocados os dinheiros públicos. Ao contrário, a técnica do orçamento-programa estrutura o gasto público em um conjunto de ações planejadas, vinculado-as ao atendimento de determinados objetivos. ${ }^{323}$

As lições de Giacomoni ${ }^{324}$ esclarecem que o orçamento-programa possui dois elementos básicos, quais sejam, o programa e atividade. O programa, como não poderia deixar de ser, é o elemento estrutural; é, ele, o instrumento por meio do qual são definidos os objetivos e metas a serem alcançados. No entanto, para lograr êxito no adimplemento dos objetivos pré-fixados, o programa conjuga um série de ações voltadas ao atendimento do escopo traçado. Nesse sentido, Giacomoni apregoa que a atividade é outro elemento essencial da estrutura do orçamento-programa. A atividade revela-se, desse modo, nas operações, nos esforços e trabalhos realizados no intuito de atingir os objetivos previstos pelo programa.

Assim, em apertada síntese, pode-se dizer que o programa propõe objetivos e metas que devem ser concretizados por meio de determinadas ações, a atividade.

Ocorre, porém, que esses programas e atividades nem sempre são suficientemente definidos, razão pela qual não indicam uma conduta precisa ao gestor público. Essa falha, em geral, não pode ser atribuída exclusivamente aos responsáveis pela elaboração do programa orçamentário. Ocorre que muitos objetivos perseguidos pelo Estado, bem como as ações que lhes correspondem, prescindem de uma materialidade mais tangível, antes, são dotadas de grande fluidez conceitual.

Mauricio Conti ${ }^{325}$, em estudo sobre o orçamento do Poder Judiciário, reconhece a dificuldade em precisar os exatos contornos das ações e objetivos consignados em alguns programas orçamentários. Ao debruçar-se sobre o orçamento do Judiciário paulista, o autor destaca que um dos programas mais pertinentes à atividade jurisdicional é aquele cuja ação consiste na "distribuição da Justiça". Mauricio Conti reconhece, posteriormente, o quão complexo e difícil é definir o conteúdo de tal atividade, pois, segundo ele, a "Justiça" é um dos conceitos mais controvertidos para o estudioso do Direito, restando praticamente impossível definir, com certeza, o conteúdo de uma

\footnotetext{
323 “A principal característica do orçamento-programa, que o distingue dos chamados métodos tradicionais, é a ênfase no objetivo do gasto, em vez da simples preocupação com a categoria do dispêndio." REZENDE, Fernando. Finanças Públicas. $2^{a}$ ed. São Paulo: Atlas, 2007. p. 104.

${ }^{324}$ GIACOMONI, James. Orçamento Público. 13 ed. São Paulo: Atlas, 2007. p. 173 a 175.

${ }^{325}$ CONTI. José Maurício. A autonomia... p. 127 a 131.
} 
atividade que opere a distribuição da justiça, sendo igualmente tormentoso apurar e quantificar os resultados obtidos com essa ação.

Nesse contexto, Giacomoni não deixa de alertar para essa deficiência do orçamento-programa. Ele aduz que "certas atividades relevantes do Estado são intangíveis, seus resultados não apresentam medições; um sistema orçamentário que valoriza sobremaneira a quantificação dos produtos finais pode, nesses casos, acabar induzindo decisões de alocação de recursos grosseiramente equivocadas."

Veja, por exemplo, o programa 1201 da Lei Orçamentária Anual para o exercício de 2012 do Estado de São Paulo. O referido programa intitula-se "Difusão Cultural" e estabelece, dentre suas ações, a "circulação cultural" cuja meta é a realização de 13 projetos. Assim, é de se questionar qual ação prática o executor do orçamento deve financiar com esta dotação. O vocábulo “cultura” é, sem sombra de dúvidas, um dos mais equívocos do vernáculo e, por certo, incontáveis ações podem ser custeadas a despeito de se promover a difusão da cultura. Diante de tal panorama, o gestor público tem à sua disposição um bom número de opções a escolher, provendo qualquer delas com o numerário destinado à “difusão da cultura".

Fica fácil atentar para o fato de que o programa que estabelece o gasto, nem sempre é capaz de indicar com precisão a conduta do executor do orçamento. As ações e objetivos do programa orçamentário, em muitos casos, possuem uma conceituação de tal modo fluída que dão margem a uma esfera discricionária para o executor do orçamento. Logo, os créditos orçamentários vinculados às ações e aos objetivos ditos intangíveis permitem que o responsável pela execução orçamentária possa destinar os recursos com um elevado grau de liberdade, selecionando, em concreto, qual o conteúdo das ações que pretende financiar e qual objetivo específico deve ser alcançado.

Pode ocorrer, também, que o programa orçamentário não seja suficientemente claro e detalhado, franqueando ao administrador público a possibilidade de integrar, discricionariamente, certas lacunas deixadas pela lei quando da efetivação do dispêndio. Nesses casos, seria perfeitamente possível definir, com precisão, os termos do programa orçamentário; entretanto, o legislador preferiu a generalidade. Assim, como bem deduz Maurício Barros:

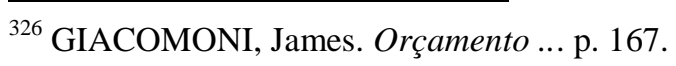


"é possível vislumbrar, dentro de um mesmo orçamento, alguns comandos de maior ou menor discricionariedade ao executor. Nesse prisma, haverá maior vinculação administrativa à lei orçamentária quanto maior for o detalhamento da previsão de gasto. 'Contrario sensu', quanto menor o detalhamento, em tese, maior seria a discricionariedade do administrador., 327

Confira, destarte, o nível de detalhamento da ação consignada no programa "Universidade do Século XXI" constante da Lei Orçamentária Anual Federal de 2005. A ação prevista contempla a construção de um edifício de 13.000 metros quadrados para a Faculdade de Ciências Econômicas da UFMG no campus da Pampulha, sendo financiada com uma dotação de $\mathrm{R} \$ 8.452 .203,00$, com a meta realização de $50 \%$ da obra no exercício financeiro de $2005 .^{328}$

Em sentido oposto, Mauricio Conti ${ }^{329}$ apresenta um exemplo bem menos detalhado e que foi colhido da Lei Orçamentária Anual do Estado de São Paulo de 2005. O programa em questão refere-se à "Construção, ampliação e reforma de edificações forenses" cuja ação é a "construção, ampliação e reforma de fóruns". Não é preciso empreender uma análise muito profunda para concluir o quão genérico é este programa orçamentário. Se no exemplo anterior, a ação minudenciava que o objeto do programa seria a construção de um prédio universitário, com uma metragem definida e em um campus determinado. No atual, a falta detalhamento programático é por demais evidente, exigindo do gestor um exercício discricionário que lhe permite escolher entre construir, reformar ou ampliar fóruns, bem como selecionar a localidade e a metragem da obra.

De toda sorte, por mais minudente que seja o programa orçamentário, é correto vislumbrar uma discricionariedade inerente à concretização do orçamento. Haverá sempre a liberdade do administrador para determinar uma gama de variáveis que decorrem da realização do gasto e que não estarão, necessariamente, previstas no orçamento. Precisamente, o executor do orçamento pode estabelecer as formas e os modos pelos quais

\footnotetext{
${ }^{327}$ BARROS, Maurício. Orçamento e Discricionariedade. In: CONTI, José Mauricio e SCAFF, Fernando Facury (coord.). Orçamentos Público... p. 1004.

${ }^{328}$ Cf. PINHIERO, Luis Felipe Valerim. Orçamento Impositivo. Dissertação de mestrado. Faculdade de Direito da USP. São Paulo: edição do autor, 2007. p. 106. (Nr: 278).

${ }^{329}$ CONTI. José Maurício. A autonomia... p. 73.
} 
a despesa será realizada. Arremata, nessa linha, Luís Felipe Valerim Pinheiro: “ $O$ administrado público definirá diversas variáveis relacionadas ao modo de execução das ações administrativas, tais como: definição do projeto básico, de equipamentos que serão instalados, a decisão sobre a realização da obra de forma direta pela Administração ou pela contratação de particulares, dentre outras." 330

Assim, mesmo que um programa orçamentário contemple, de modo detalhado, a conduta material a ser efetivada pelo gestor público, remanescerá sempre a faculdade discricionária para escolher algumas particularidades relativas ao modo e à forma como a despesa deve ser concretizada. Retome-se o exemplo da construção do prédio da universidade: ainda que o orçamento estabeleça o local, a metragem e a finalidade da obra, restará alguma discrição quanto à escolha do projeto arquitetônico, dos materiais a serem empregados, dentre outras particularidades imprevisíveis no programa orçamentário.

Desse modo, a execução do orçamento resulta indissociável do exercício de faculdades discricionárias por parte do administrador. Seja porque os programas orçamentários são descritos com conceitos intangíveis, seja porque a descrição programática é genérica e, ainda, porque existem opções quanto à forma e o modo de se realizar uma despesa, cabe ao executor do orçamento integrar, discricionariamente, a norma orçamentária no intuito de concretizá-la, conferindo-lhe a efetividade prática.

Reafirme-se que a execução do orçamento confere ao gestor uma discricionariedade nitidamente administrativa, uma vez que a discrição decorre diretamente da lei e não se presta a determinar quais são as finalidades públicas e os meios a ela inerentes. Os fins e os meios definidos politicamente já foram, previamente, inseridos no orçamento ou decorrem de sua natureza autorizativa, cabendo pela via da discricionariedade administrativa encontrar, no caso concreto, qual medida melhor satisfaz a finalidade já definida pelo interesse público.

Destarte, a execução das dotações orçamentárias franqueia ao gestor público as faculdades para que ele possa eleger, segundo critérios de conveniência e oportunidade, as medidas mais condizentes com a satisfação das finalidades contempladas no orçamento.

${ }^{330}{ }^{330}$ PINHEIRO, Luis Felipe Valerim. Orçamento... p. 107 


\section{A FISCALIZAÇÃO FINANCEIRA QUANTO À LEGITIMIDADE MEDIANTE CONTROLE EXTERNO.}

A fiscalização financeira quanto à legitimidade, que se exerce mediante controle externo, franqueia a possibilidade de se examinar materialmente a atuação financeira do Estado. Sem laivos de dúvida, a fiscalização deixa de se concentrar na mera legalidade contábil e passa a aferir a correção substantiva dos atos de gestão pública. Esse nova competência dos órgãos de fiscalização esbarra, nitidamente, nas faculdades discricionárias dos agentes políticos e administrativos e, nesse contexto, é preciso verificar em que medida a apuração da legitimidade das finanças públicas habilita os órgãos de controle a enfrentar o mérito das opções discricionárias.

Como se expôs alhures, a atividade financeira do Estado comporta o exercício de duas faculdades discricionárias distintas. Uma política, mais plástica e dilatada, cuja missão é definir quais as finalidades públicas e os meios para alcançá-la, e outra meramente administrativa que busca, no caso concreto, eleger a medida mais conveniente à consecução das finalidades encampadas.

Mas a discricionariedade, seja ela política ou administrativa, não pode escapar ao controle. Nota-se que distinção entre atos políticos e administrativos não deixa de suscitar críticas no que toca à ampla discricionariedade e, consequentemente, à maior insindicabilidade dos atos políticos. É emblemática a doutrina de García de Enterrìa ${ }^{331}$ que refuta a teoria dos atos políticos por entender que o Estado de Direito é um Estado de Justiça, no sentido explícito de justiça jurisdicional, perante a qual o poder público e seus titulares não podem pretender nenhuma imunidade, sob pena de negar a tutela jurisdicional aos cidadãos.

Embora expresse as mesmas preocupações de García de Enterrìa, Cretella Júnior adota uma postura menos radical, buscando a preservação de um âmbito de escolhas políticas, sem negar, contudo, a jurisdição aos que dela necessitarem. In verbis: “Movimente-se o Poder Judiciário com amplitude, mas com amplitude discreta e cuidadosa que não interfira, por um lado no cerne do problema estritamente político, e não desampare, por outro lado, o direito individual., 332

\footnotetext{
${ }^{331}$ Cf. GARCÍA DE ENTERRÍA, Eduardo. Democracia, Jueces... p. 171, 172 e 279 a 284.

${ }^{332}$ CRETELLA JÚNIOR, José. Tratado de Direito... p. 126.
} 
O fato é que as escolhas derivadas da discricionariedade política devem ter uma imunidade maior em relação aos organismos de controle, pois a definição dos fins últimos do Estado é confiada, sobretudo nos regimes democráticos, a órgãos de representação política que expressam, ao menos em tese, as convicções e anseios da maioria. Isso não significa que as opções políticas escapem ao controle, este, todavia, não pode ser exercitado de modo estrito, rígido e objetivo.

Ocorre que as opções políticas não se encaixam em esquemas fechados, devem, antes, gozar de uma ampla liberdade, visto que podem ser emanadas segundo as mais variadas convicções e de acordo com as mais diversificadas conjunturas. ${ }^{333}$ Logo, o controle que sobre elas recai deve ser de tal modo plástico que exclua fórmulas apriorísticas de correção. Ora, um controle baseado em modelos objetivos bloquearia, certamente, a capacidade dos atores políticos de buscar, com liberdade e variabilidade, as finalidades mais aptas a consubstanciar o bem comum.

Em especial no aspecto financeiro - no qual as decisões políticas se assentam sobre um número incalculável de opções quanto às prioridades, metas e destinação programática dos recursos públicos -, qualquer mecanismo de controle deve ter a preocupação institucional de preservar a discrição política, furtando-se em empregar parâmetros rígidos de correção. ${ }^{334}$ Em última análise, deseja-se evitar que um controle baseado em padrões mais objetivos possa suplantar as prerrogativas dos agentes políticos para determinar, segundo suas próprias valorações, as finalidades e as diretrizes da atividade financeira do Estado.

Já no tocante à discricionariedade administrativa em matéria financeira, é possível advogar que o controle a ser exercido pode adotar padrões de correção mais vigorosos e estritos.

A discricionariedade administrativa no campo financeiro dirige-se à gestão direta dos recursos públicos. Seu exercício não visa definir finalidades e diretrizes globais,

\footnotetext{
333 Como leciona Antonio Amorth: "L’attività di governo, inifne, per il còmpito che le è próprio; è essenzialmente discrizionale, cosicchè essa può essere determinata e regolata solo dalla considerazione dell' interesse generale dello Stato (...). ”AMORTH, Antonio. Atti ... p. 186.

${ }^{334}$ Recorra-se, nesse particular, às lições de Francesc Vallès Vives ao traçar peculiaridades do chamado controle político, em oposição ao controle jurídico. Segundo ele: "Para el control jurídico el parámetro del control, está formado por normas de derecho indisponibiles para el agente que realiza el control. El parámetro está así, juridicamente objetivado, y, en consecuencia, es indisponible y preexistente. Sin embargo, sigue Aragón, 'el control politico es por su propia naturaleza subjetivo, lo que implica todo lo contrario al anterior: el parámetro de control es no objetivado, disponible y no necesariamente preexistente' Es decir, el carácter subjetivo del parámetro ”VIVES, Francesc Vallès. El controle... p. 152.
} 
mas permite que o administrador eleja, no caso específico, a medida que melhor concretize as finalidades já descritas no plano de gastos. Nesse caso, nada impede que o controle seja mais incisivo no intuito de coibir qualquer desvio de finalidade ou impropriedade na execução orçamentária. Como recorda Válle Vives ${ }^{335}$, os órgãos voltados ao controle de gestão administrativa não estão impedidos de realizar juízos valorativos acerca das escolhas discricionárias, desde que o alcance dessa prerrogativa não esbarre em atos de conteúdo político para os quais se prevê um controle diferenciado.

Particularmente, o juízo do organismo de controle administrativo não se presta a contraditar as prioridades e as finalidades que a despesa quer alcançar, mas sim se os atos que lhe promoveram a execução pautaram-se pela correção proposta pelo ordenamento jurídico.

Não se despreze o fato de que o ordenamento prevê uma série de princípios, diretivas e programas que mitigam a liberdade do gestor e balizam espectro discricionário da execução orçamentária. E, por certo, a intensidade prescritiva desses fatores de limitação discricionária é muito maior no campo administrativo, se comparada ao campo político. Vale recordar que a atividade de governo ou política é essencialmente discricionária e não pode ser definida a priori; já a atividade administrativa é, por excelência, vinculada e a discricionariedade da administração só existirá caso seja autorizada pelo ordenamento. ${ }^{336}$ Logo, o influxo da ordem jurídica é sobremaneira acentuado no exercício da discricionariedade administrativa, constrangendo o gestor a adotar soluções que sejam compatíveis com a correção indicada pelo sistema normativo.

Assim, a discricionariedade administrativa que se extrai da atividade financeira está limitada por padrões jurídicos mais rígidos, reclamando um controle mais efetivo e capaz de imprimir mais eficiência, transparência e moralidade na gestão dos recursos públicos. É claro, porém, que se deve resguardar a esfera de discrição administrativa facultada ao gestor público. Todavia, os abusos, arbitrariedades e incorreções estarão, como já se expôs, sujeitos a censura.

Sobretudo, importa notar no campo financeiro que a existência de duas esferas distintas de discricionariedade reclama duas espécies diversas de controle. Deve

\footnotetext{
335 "Parece pues que nada impide que el controle externo realice juicios valorativos sobre el gasto público. La única limitación existente se encontra en el alcance de essa función, y sobre todo en el de sus efectos. Estos deberían quedar atenuados de tal forma que no puedan afectar el ejercicio del control político.’VIVES, Francesc Vallès. El controle...p. 153.

${ }^{336}$ AMORTH, Antonio. Atti ... p. 183.
} 
existir um controle de padrões correcionais mais frágeis que traga garantias ao exercício da discricionariedade política e um controle mais rígido que se concentra na execução orçamentária de maneira a exigir dos gestores uma conduta condizente com as prescrições do plano de gasto e com os mandamentos do ordenamento jurídico.

Assim, diante dessas constatações é possível afirmar que o constituinte não se fez alheio à problemática da preservação da discricionariedade a despeito de estabelecer um robusto sistema de controle financeiro, pois estabeleceu dois regimes distintos para a fiscalização das contas públicas. A CF de 1988 prevê, nesse sentido, um controle político mais subjetivo e discricionário a cargo do Legislativo e um controle de gestão mais estrito a cargo do Tribunal de Contas.

3.1. Os regimes de apuração das contas públicas: contas de governo e contas de gestão.

A doutrina de José de Ribamar Caldas Furtado expõe uma interessante exegese constitucional acerca do chamado controle externo. Das suas lições é possível extrair que a Constituição não estabeleceu um regime único para a apreciação e julgamento das contas públicas, pelo contrário, a fiscalização financeira mediante o controle externo se exerce sob o influxo de dois regimes jurídicos distintos que são encampados, respectivamente, pelo Tribunal de Contas e pelo Legislativo. Atesta o autor:

“Existem dois regimes jurídicos das contas públicas: a) o que abrange as contas de governo, exclusivo para a gestão política do chefe do Poder Executivo, que prevê o julgamento político levado a efeito pelo Parlamento, mediante o auxílio do Tribunal de Contas, que emitirá o parecer prévio (CF, art. 71, I, c/c art. 49, IX); b) o que alcança as intituladas contas de gestão, prestadas ou tomadas, dos administradores de 
recursos públicos, que impõe o julgamento técnico realizado em caráter definitivo pela Corte de Contas (art. 71, II)",337

Em relação ao regime das contas de governo é preciso sublinhar que o Legislativo leva a efeito um julgamento notoriamente político. Note que o juízo final exarado sobre as contas do Chefe do Poder Executivo não se baseia em critérios jurídicos pré-determinados, mas em apreciações subjetivas e momentâneas que revelam o caráter extremamente discricionário do julgamento perpetrado pelo Parlamento. ${ }^{338}$

Como bem esclarecem Pederiva e Pontes, a competência do Congresso para julgar as contas de governo faz parte do chamado controle político, consistindo, em essência, na constante avaliação de desempenho do Governo no tocante à apresentação e à execução de planos e da adequação destes à solução dos problemas existentes. Concluem afirmando que o julgamento das contas do Chefe do Executivo não se trata de controle sobre os atos de rotina administrativa, mas sobre o mérito de medidas e diretrizes fundamentais para o País. ${ }^{339}$

Ao julgar as contas prestadas pelo Chefe do Executivo, o Parlamento não se debruça sobre situações individualizadas e concretas, mas analisa a aptidão genérica da atuação governamental em resolver as deficiências socioeconômicas que grassam no país. $\mathrm{Na}$ verdade, o que acaba ocorrendo é que este tipo de controle concentra-se muito mais sobre os resultados auferidos a partir da gestão pública, deixando de empregar paradigmas jurídicos que atestariam a licitude das condutas. Portanto, a análise das contas de governo prescinde de contrastar as contas com padrões estritos de correção de modo que o julgamento se processa com larguíssima liberdade e a sentença final fica a depender do alvedrio subjetivo dos parlamentares.

De fato, não há como negar que esse juízo subjetivo do Parlamento é capaz de criar alguma insegurança, uma vez que inexistem critérios objetivos que poderiam fundamentar racionalmente o julgamento. ${ }^{340}$ Todavia, é preciso esclarecer que a previsão

\footnotetext{
${ }^{337}$ FURTADO, José de Ribamar Caldas. Os regimes de Contas Públicas: contas de governo e contas de gestão. Revista do Tribunal de Contas da União, Brasília, n. 109, mai/ago, 2007. p. 69.

338 "Mas é que os julgamentos legislativos se dão por um critério subjetivo de conveniência e oportunidade, critério, esse, que é forma discricionária de avaliar fatos e pessoas." BRITTO, Carlos Ayres. O Regime Constitucional... p. 2.

${ }^{339}$ PEDERIVA, João Henrique e PONTES, João Batista. Contas ... p. 7.

${ }^{340}$ Quanto às críticas, confira o parecer de Pederiva e Pontes: “O juízo de valor configurado no julgamento de contas demanda a prévia fixação de parâmetros norteadores dessa apreciação. Entretanto, também os critérios para a aprovação ou a rejeição das Contas do Governo e as consequências práticas que cada
} 
constitucional de um julgamento político acaba por preservar a discricionariedade do Chefe do Executivo na direção geral do Estado. Ciente de que não se submeterá a um julgamento baseado em critérios definidos aprioristicamente, o Chefe do Executivo exerce com tranquilidade a discricionariedade política que lhe permite traçar os rumos da ação estatal. Em outras palavras, a fluidez e a subjetividade próprias ao julgamento político propiciam uma maior desenvoltura no exercício das faculdades discricionárias, imunizando, em alguma medida, o Chefe do Poder Executivo quanto à prerrogativa de eleger os fins e os meios encampados pelo planejamento financeiro do Estado.

Assim, se foi possível verificar a existência de uma esfera discricionária de viés político e que importa na definição de finalidades e diretrizes em matéria financeira, é verdade, também, que o controle dessas decisões será igualmente discricionário, furtandose em submeter as decisões políticas a critérios rígidos de correção. Desse modo, toda questão política envolvendo o campo orçamentário fica excluída de um controle mais objetivo, cabendo ao Legislativo apreciar, subjetivamente, a procedência da direção global da atuação financeira do Estado.

Precisamente, todo o aspecto político relacionado ao processo orçamentário está sujeito ao julgamento efetuado pelos parlamentares. Ou seja, a destinação dos recursos quando da elaboração do orçamento, o uso de mecanismos de flexibilidade orçamentária e o possível contingenciamento das dotações ficam sob o juízo do Legislativo quando do julgamento final das contas apresentadas pelo Chefe do Poder Executivo.

Todavia, não obstante o julgamento das contas de governo tenha o condão de preservar a discricionariedade afeita às definições políticas, impende reconhecer que esse tipo de controle acaba funcionando como um relevante instrumento de limitação do poder, se considerada a proeminência do Chefe do Executivo em relação à condução financeira do Estado. ${ }^{341}$

Como se afirmou anteriormente, a atuação institucional e prática do Executivo em relação às finanças públicas sobrepuja, flagrantemente, o Poder Legislativo. Compete, exclusivamente, ao Chefe Poder Executivo projetar o orçamento futuro, definindo, assim, os cotornos fundamentais da atuação financeira do Estado; ainda, no

decisão deve produzir no Governo, bem como sobre as circunstâncias que ensejariam a responsabilização integral ou parcial do Presidente da República, grassam imprecisão e incerteza.” Ibid. p. 11.

${ }^{341}$ Embora as contas prestadas pelo Executivo abarquem as contas dos demais Poderes e do Ministério Público (art. 56 da LRF), o julgamento recai apenas na figura do Chefe do Executivo, pois, segundo Pederiva e Pontes, credita-se a ele a relevância na arrecadação de recursos para a prestação de bens e serviços e para a garantia das condições de infra-estrutura fundamentais ao desenvolvimento do país. Ibid. P. 10. 
curso da execução orçamentária o Executivo pode propor a alteração do orçamento e contingenciar dotações, bem como possui o controle da estimação e da entrada efetiva das receitas públicas. Ao Legislativo resta, muitas vezes, conceder uma mera chancela autorizativa às pretensões do Executivo, pois mesmo a possibilidade de emendar o projeto orçamentário encontra fortes óbices constitucionais e práticos.

Válles Vives encontrando esse mesmo panorama na Espanha faz um apontamento que pode muito bem ser aplicado à realidade brasileira. Constata ele que:

"o único instrumento político minimamente efetivo em matéria orçamentária que, atualmente, podem utilizar tanto a situação como a oposição e que permite equilibrar, até certo ponto, o desigual protagonismo dos poderes do Estado em relação ao orçamento, se encontra na fase de controle, normalmente posterior a atuação e execução orçamentária do Governo" 342

Logo, ainda que se possa fazer alguma crítica quanto ao caráter extremamente subjetivo do julgamento das contas de governo pelo Legislativo, não se pode deixar de reconhecer nessa competência julgadora um importante expediente para limitar e controlar a proeminência do Executivo em matéria financeira.

O julgamento político a cargo do Legislativo tem uma razão de ser e, portanto, deve ser empreendido para minar pretensões ilegítimas do Chefe do Executivo. Não obstante o Executivo detenha prerrogativas políticas institucionais em relação à condução orçamentária, é fato que tais faculdades não podem ser pervertidas em prejuízo da harmonia e da independência dos Poderes. Caso o Executivo corrompa a finalidade de suas competências, essa malversação das suas faculdades institucionais não pode deixar de influenciar no julgamento político a ser realizado pelos parlamentares. Precisamente, se a proeminência do Executivo em matéria orçamentária se faz à custa do aviltamento da

\footnotetext{
342 “el único instrumento político mínimamente efectivo en materia presupuestaria que, actualmente, pueden utilizar tanto la mayoría parlamentaria, como la minoría, y que permite equilibrar, hasta cierto punto, el desigual protagonismo de los poderes del Estado en relación al presupuesto, se encuentra en la fase de control, normalmente posterior a la actuación y ejecución presupuestaria del gobierno" VIVES, Francesc Vallès. El controle...p. 134.
} 
independência dos Poderes, essa situação não pode passar despercebida, merecendo o juízo condenatório do Poder Legislativo.

De outra sorte, vale sublinhar que o Legislativo julga a conduta global do Chefe do Executivo. Não está sobre o juízo do Legislativo a análise de fatos isolados e rotineiros, mas a capacidade genérica do Chefe do Executivo em conduzir a bom termo a atividade financeira do Estado. Para os atos de administração quotidiana se reserva outra espécie de controle, o chamado regime de apuração das contas de gestão.

Cosoante a previsão do art. 71, II, da CF de 1988, compete ao Tribunal de Contas julgar os administradores e responsáveis por bens e valores públicos, bem como aqueles que derem causa a qualquer prejuízo ao erário público. Nesses termos, a atribuição julgadora da Corte de Contas volta-se ao controle da gestão individual dos recursos públicos, detendo-se, portanto, sobre atos de administração singulares e definidos.

Nesse sentido, no âmbito do Tribunal de Contas não se cogita a verificação dos atos políticos do Chefe do Executivo, pois não se analisam os macro-efeitos da atuação financeira e o impacto socioeconômico logrado com as finalidades encampadas pelo orçamento. O intento das Cortes de Contas é fiscalizar e julgar qualquer impropriedade no trato quotidiano da gestão dos recursos públicos. Em outras palavras, à Corte de Contas cabe contrastar a correção dos atos administrativos empregados na concretização da atividade financeira do Estado, impondo, se necessário, as sanções aos responsáveis.

Desse modo, o critério que orienta a aprovação ou reprovação das contas de gestão não se encontra na subjetividade dos julgadores. Antes, os agentes responsáveis pelo julgamento valem-se do ordenamento posto que, por sua vez, já vinculava a ação dos administradores públicos. Anota, com propriedade, Carlos Ayres Britto ${ }^{343}$, que os julgamentos dos Tribunais de Contas adotam parâmetros de ordem técnico-jurídica, ou seja, parâmetros que importam na subsunção de fatos e pessoas à ordem legal e constitucional.

É inegável o acento prescritivo do ordenamento na gestão rotineira das finanças públicas, pois se no âmbito das atribuições de governo o ordenamento se mostra muito mais plástico, no particular da atividade administrativa ele exige uma conduta mais vinculada à lei. Destarte, o controle da discricionariedade administrativa pela Corte de Contas resulta muito mais vigoroso se comparado ao controle legislativo da

\footnotetext{
${ }^{343}$ BRITTO, Carlos Ayres. O Regime Constitucional... p. 2.
} 
discricionariedade política. Ao se debruçar sobre os pormenores individualizados da gestão administrativa dos recursos públicos a Corte pode conferir, com maior efetividade, se os atos realizados em virtude de faculdades discricionárias lograram respeitar as limitações e constrições impostas pelo ordenamento.

Desse modo, é imperioso constatar que a dualidade do regime de apuração de contas possibilita salvaguardar os critérios de conveniência e oportunidade que orientaram a condução política da atividade financeira do Estado, uma vez que o exercício da discricionariedade política, que o Executivo assume, fica subtraída do julgamento realizado pelo Tribunal de Contas.

Note que a discricionariedade política em matéria financeira é atribuída essencialmente ao Executivo e está sujeita um julgamento de critérios mais fluídos a cargo do Legislativo, preservando, assim, a liberdade para definir os fins e os meios da atuação financeira. De outro lado, as competências do Tribunal de Contas não se prestam a julgar decisões globais de conveniência política, mas recaem sobre os atos dos administradores e responsáveis por bens e valores públicos quando da gestão concreta do patrimônio estatal.

Logo, o Tribunal de Contas não poderá controlar a condução global da atividade financeira, invadindo o mérito das escolhas do Executivo. Em outras palavras, o Tribunal de Contas não pode discutir a alocação dos recursos contemplados na lei orçamentária, muito menos enfrentar as razões que levaram o Executivo a se valer do contingenciamento e dos mecanismos de flexibilidade. Tudo isso se inclui no juízo do Legislativo quando do julgamento das contas do Chefe do Executivo.

No entanto, nada impede o Tribunal de Contas de sindicar os administradores de bens e valores públicos na sua missão de concretizar a gestão financeira delineada pelo Governo, apurando, nesse diapasão, se atuação discricionária dos gestores está de acordo com os padrões expressos pelo ordenamento.

\subsection{O controle da legitimidade e o Poder Legislativo.}

A previsão de um julgamento genérico e de cunho político pelo Poder Legislativo coaduna-se com a preservação dos critérios políticos de conveniência e 
oportunidade que permitem ao Chefe do Executivo definir, com liberdade, os contornos globais da atuação financeira do Estado.

Isso porque, como já se frisou, o julgamento das contas do Chefe do Executivo não se baseia em critérios estritos, mas em disposições subjetivas dos parlamentares. Ressalte-se que o Legislativo constata o desempenho do Executivo na direção geral das finanças públicas, avaliando, portanto, o resultado de decisões altamente maleáveis, tomadas sob o influxo das mais variadas posições ideologicas e conjecturais.

Nesse sentido, seria inconcebível constranger os parlamentares a adotar padrões objetivos para julgar as contas, primeiro porque as decisões políticas não estão, no mais das vezes, motivadas por uma ponderação categórica de certo ou errado. Como já se apontou, a definição política é essencialmente discricionária e está atrelada às convicções dos atores que, momentaneamente, detém o poder. Em segundo lugar, o êxito das medidas adotadas politicamente não está condicionado, simplesmente, pela capacidade delas em produzir os resultados almejados. O sucesso das decisões políticas depende de diversos matizes que, seguramente, não podem ser dominados ou previstos pelos agentes políticos.

Em outro sentido, o julgamento de escolhas de índole política e que fogem à pretensão de uma legalidade mais robusta é muito pertinente ao Parlamento, uma vez que este se erige como "a" casa de representação popular e ostenta, nessa condição, a fonte de todo o poder. ${ }^{344}$ Assim sendo, cabe ao Poder Legislativo prestar a chancela definitiva à condução política das finanças públicas que, em última análise, foi realizada mediante a autorização da própria vontade popular. ${ }^{345}$

Resta claro, desse modo, que o julgamento dos atos de governo na condução das finanças públicas só poderia ser de índole parlamentar e política, adotando como elemento de correção opiniões subjetivas que podem avaliar, com menor interferência, a variabilidade inerente às escolhas políticas.

Mas além de contribuir para preservar a discricionariedade política do Chefe do Executivo, o caráter genérico do julgamento de contas pelo Legislativo franqueia a

\footnotetext{
${ }^{344}$ Art. $1^{\circ}$, par. único, da CF: "Todo poder emana do povo e em seu nome é exercido."

345 Não são outras as lições de Válles Vives: "Lo importante, es pues, que la iniciativa presupuestaria gubernamental y su posterior ejecución administrativa sean sancionadas por el Legislativo. Lo que el principio democrático pretende garantizar es, no tanto un efectivo control "por" el legislativo (para eso ya se crearan los órganos de control externo; independientes en lo funcional, y dedicados en exclusiva a realizar esta función con muchos más recursos económicos, materiales y personales que la institución parlamentaria), sino más bien que este control sea ejerció "en” el Parlamento. Es decir, el principio democrático exige que la actuación del Ejecutivo y de la Administración en general sea controlada en sede parlamentaria" VIVES, Francesc Vallès. El controle...p. 36.
} 
possibilidade de se analisar a legitimidade das opções tomadas no direcionamento das finanças estatais. José de Ribamar Caldas Furtado preleciona que no juízo do Legislativo sobre as contas de governo "a legalidade cede espaço para a legitimidade"346, pois o cerne do julgamento não leva em consideração a subsunção de fatos às normas legais, mas sim a efetividade e o desempenho dos planos e programas, bem como a conveniência do direcionamento global da execução orçamentária.

O art. 70 da CF de 1988 não deixa de destacar que o controle externo exercido pelo Congresso levará em conta não só a aferição da economicidade e da legalidade, mas também a apuração da legitimidade. ${ }^{347}$ Dessa maneira, muito embora o controle político de contas seja mais maleável, o Parlamento está habilitado a julgar desvios éticos que, invariavelmente, permeiam a condução geral das finanças públicas.

Por exemplo, não se afiguraria legítimo empregar considerável soma de recursos em atrativos culturais, enquanto o serviço público de saúde padecesse de graves problemas. Nesse caso, mesmo que houvesse perfeito atendimento à legalidade, ao menos em seu aspecto formal, a situação não deixaria de ser reprovável. A legitimidade das opções políticas quanto à definição das despesas públicas e a sua posterior execução pressupõem que elas contemplem, com um mínimo de satisfatoriedade, a promoção das necessidades humanas mais básicas e fundamentais.

A toda evidência, se posteriormente se verificar que a formatação e a execução orçamentária não priorizaram o atendimento de reclames sociais e individuais indispensáveis, tais como saúde e educação, é certo vislumbrar que a atuação pouco preocupada do Executivo não merece a aprovação final por parte do Legislativo.

Ademais, não só o campo da configuração das despesas e receitas está sujeito a um juízo de legitimidade ou ilegitimidade. Todo o relacionamento entre o Executivo e o Legislativo no campo orçamentário pode figurar como substrato para influir no julgamento das contas de governo. Nesse contexto, é possível citar a ilegitimidade de uma prática recriminável e recorrente do Executivo que condiciona a liberação de emendas parlamentares à aprovação de projetos de seu interesse. Helio Tollini descreve com precisão essa conduta:

\footnotetext{
${ }^{346}$ FURTADO, José de Ribamar Caldas. Os regimes... p.71.

347 Apesar de não se valer de critérios legais de correção quando do julgamento político do Chefe do Executivo, o Legislativo não pode se furtar a observar regras legais quanto ao procedimento (devido processo legal), garantido, assim, a publicidade, a transparência, a ampla defesa e o contraditório. FURTADO, José de Ribamar Caldas. Os regimes... p.71.
} 
"Enquanto os parlamentares beneficiam-se politicamente com a possibilidade de destinar recursos federais para suas bases eleitorais, o Poder Executivo utiliza as emendas como mecanismo de cooptação em suas relações com os partidos políticos, ao aproveitar-se do caráter autorizativo da LOA para condicionar a execução das emendas individuais à votação pelos parlamentares dos projetos de interesse do Executivo nas votações do Congresso Nacional., 348

Em outras palavras, o Executivo, titularizando a execução orçamentária e podendo contingenciar as dotações, usa dessas prerrogativas para chantagear os parlamentares, que, por sua vez, só teriam suas emendas orçamentárias efetivadas caso mostrassem subserviência aos projetos de interesse do Poder Executivo.

Essa prática, de modo algum, revela-se consentânea com os padrões morais que devem nutrir a conduta institucional dos agentes de Estado. O Executivo não pode constranger a liberdade dos parlamentares forçando-os a apoiar determinado projeto, pois muito embora a composição entre os políticos faça parte dos mecanismos democráticos, é evidente que o Poder Executivo não pode usar da prerrogativa de contingenciar dotações para condicionar a adesão dos parlamentares aos projetos de seu interesse. O contingenciamento de dotações se presta a atender metas fiscais e reservar recursos para aplicação em despesas mais prementes, destarte, a finalidade desse expediente orçamentário não pode ser pervertida para minar a autodeterminação da vontade parlamentar.

Esse uso tortuoso do contingenciamento não pode passar despercebido quando do julgamento das contas de governo pelo Legislativo. Reafirme-se que o juízo do Parlamento não se destina a apurar irregularidades contábeis, mas verificar, sobretudo, a legitimidade do Poder Executivo no impulso das finanças estatais. Caso o Executivo corrompa a finalidade de mecanismos de flexibilidade orçamentária, como o contingenciamento, esse fato merece a reprovação do Legislativo no momento do julgamento das contas.

\footnotetext{
${ }^{348}$ TOLLINI, Helio. Em busca de uma participação mais efetiva do Congresso Nacional no processo de elaboração orçamentária. Brasília: Biblioteca Digital da Câmara dos Deputados, 2008. p.15.
} 
Mas tal qual o abuso em relação ao uso viciado do contingenciamento, a discricionariedade política do Executivo para conduzir a gestão global das finanças públicas pode revelar-se um campo fértil para a perpetração de arbitrariedades. Ocorre, infelizmente, que essas arbitrariedades acabam encontrando respaldo nas vicissitudes que maculam o processo de julgamento de contas do Chefe do Executivo pelo Parlamento.

Registre-se, antes de tudo, que a Constituição, tendo preconizado um julgamento político do Executivo quanto à gestão financeira do Estado, não previu qualquer sanção para a hipótese de rejeição das contas. Assim, não obstante os parlamentares possam aferir a legitimidade das contas de governo, a eventual reprovação delas não leva a nenhuma consequência prevista constitucionalmente. O juízo negativo sobre as contas do Executivo não conduz, obrigatoriamente, à perda do mandato, à configuração de crime de responsabilidade ou a qualquer outra penalidade pecuniária. A única consequência está na legislação infraconstitucional, a saber, na alínea "g" do art. $1^{\text {o }}$ da Lei Complementar 64 de 1990, a lei de inelegibilidades. Conforme o referido preceito, estão inelegíveis por oito anos aqueles que tiverem as contas rejeitadas pelos órgãos competentes, quais sejam, os Tribunais de Contas e os Legislativos das esferas estadual, municipal e federal.

Não obstante essa sanção seja considerável, em se tratando de agentes políticos, é ponto indiscutível que tal punição não se dá de maneira imediata aos fatos. Tendo em vista que o julgamento das contas de governo é anual, a possível reprovação ocorrida no início, ou no meio do mandato, só inabilitaria o agente para as futuras eleições, não acarretando qualquer consequência imediata. Essa falta de proximidade temporal entre o julgamento e a sanção imposta corrói qualquer intento pedagógico que a punibilidade poderia promover, não compelindo, portanto, o agente político faltoso a adotar medidas mais condizentes com legitimidade da atuação financeira do Estado.

De outro modo, a punição de inelegibilidade em si não é apta para coagir o Chefe do Executivo a alterar, no exercício seguinte, as possíveis impropriedades que causaram a reprovação das contas. Não há, pois, nenhuma determinação sancionadora que impeça o Chefe do Executivo de repetir os atos que, eventualmente, proporcionaram-lhe a reprovação das contas. Logo, é indeclinável reconhecer que a ausência de sanções mais imediatas e compatíveis com o juízo político das contas logra enfraquecer e incapacitar a função do Legislativo em julgar a prestação de contas do Chefe do Poder Executivo. 
Outrossim, constata-se que os parlamentares federais têm dado pouca importância à função de julgar as contas. De fato, não se pode afirmar que essa conduta se repete em todos os âmbitos da Federação, mas se as contas do governo da República merecem tão pouco prestígio, é o caso de se considerar o quão ineficaz se mostra o julgamento das contas de governo pelo Legislativo.

Pederiva e Pontes ${ }^{349}$ traçam o panorama trágico do julgamento de contas pelo Congresso Nacional e verificam o total desinteresse dos parlamentares em apreciar e julgar as contas do Executivo. Eles relatam que: a) as contas de 1990, 1991 e 1992 ainda não foram deliberadas e aprovadas; b) as contas do governo FHC (1995 a 2001) foram aprovadas de um só impulso e sem um debate aprofundado, sublinhando-se que as contas de 1995, 2000 e 2001 foram aprovadas sem as formalidades processuais exigidas.

Conforme estudo de Rosanne Mannarino, até 2006 as contas referentes ao exercício de 2002, 2003, 2004 não haviam sido apreciadas e julgadas. ${ }^{350}$

Com uma rápida pesquisa no sítio eletrônico da Câmara Federal no nicho “Contas do Governo Federal”, é possível verificar, desde logo, que as contas de 2009 e 2010 sequer foram apreciadas pela Comissão Mista de Orçamentos, bem como não houve o julgamento das contas relativas ao Governo do Presidente Lula e da Presidente Dilma, precisamente, as contas dos exercícios de 2002 a 2009 não foram julgadas pelo Congresso Nacional. $^{351}$

O quadro institucional do julgamento das contas pelo Legislativo é desolador. Pouco adianta promover o juízo de legitimidade acerca dos atos de discrição política do Executivo, se a atuação parlamentar mostra-se tão despreocupada. O que se nota na prática, portanto, é que o controle de legitimidade da gestão financeira exercido pelo Parlamento não logra encontrar um apelo efetivo, minando o desiderato constitucional de limitar e conter a discricionariedade política do Chefe do Executivo em matéria financeira.

\footnotetext{
${ }^{349}$ PEDERIVA, João Henrique e PONTES, João Batista. Contas ... p. 14.

${ }^{350}$ MANNARINO, Rosanne. Prestação de ... p. 234.

${ }^{351} \mathrm{Cf}$. http://www2.camara.gov.br/atividade-legislativa/orcamentobrasil/copy_of prestacao Acesso: 12.05 . 2012.
} 


\subsection{O controle da legitimidade e o Tribunal de Contas.}

No particular do controle externo financeiro já se consignou que a possibilidade do Tribunal de Contas sindicar o aspecto da legitimidade permite-lhe adentrar nos aspectos de conveniência e oportunidade que determinam as escolhas discricionárias. Objetou-se, em seguida, que a lógica inerente ao sistema não permite aos órgãos de controle - notadamente, o Judiciário e o Tribunal de Contas - invadir a esfera discricionária própria da Administração, subtraindo-lhe a capacidade de eleger, no caso concreto, qual opção melhor satisfaz o interesse público.

Na verdade, ocorre que os órgãos de controle estão habilitados a avaliar o espectro do mérito não para se erigir como administradores, mas com a finalidade de constatar qualquer abuso, arbítrio e irregularidades no uso das faculdades discricionárias. Se o mérito resta viciado, não há que se invocar a insindicabilidade das escolhas discricionárias para promover a imunização do erro. A toda evidência, o exercício tortuoso, arbitrário e despropositado da discricionariedade deve ensejar a revisão e a correção do ato administrativo por parte dos órgãos de controle, sob pena de se instaurar um regime de tolerância com abusos e incorreções.

Ainda assim, não se pode deixar de notar que o enfrentamento da discricionariedade por parte do Tribunal de Contas difere do enfrentamento proposto ao Legislativo. Diversamente do que ocorre no julgamento de contas perpetrado pelo Poder Legislativo, que se debruça sobre a avaliação política da atividade financeira do Estado, a atuação sindicante do Tribunal de Contas está inserida dentro de um regime específico de apuração das contas. Este órgão não constata a correção de escolhas políticas globais, mas fiscaliza atos de administração individualizados que concretizam as disposições orçamentárias e que gerenciam os bens e os recursos públicos. Nesse sentido, o julgamento efetuado pelas Cortes de Contas não se dirige, exclusivamente, ao Chefe do Poder Executivo, mas a todos os administradores e responsáveis por bens e valores públicos.

Advogue-se, mais uma vez, que essa distinção quanto às funções de controle externo do Legislativo e do Tribunal de Contas dá-se em prestígio da preservação de critérios políticos de discricionariedade, uma vez que as escolhas dos agentes de Estado quanto à direção geral das finanças públicas não está sujeita ao controle rígido das Cortes de Contas. A atuação política do Chefe do Executivo submete-se a um juízo maleável e 
subjetivo dos parlamentares, assim, o Tribunal de Contas não está constitucionalmente autorizado a rever critérios relativos à orientação política da atividade financeira do Estado, tais como a definição das receitas e despesas no orçamento, a adoção de mecanismos de flexibilidade orçamentária e possibilidade de contingenciar dotações. Esses aspectos estarão sob o crivo do julgamento político preconizado pelo Parlamento.

Todavia, a apuração da legitimidade pelo Tribunal de Contas o habilita a conferir sobre os critérios de conveniência e oportunidade decorrentes do exercício de uma discricionariedade nitidamente administrativa. Nota-se que a concretização da programação orçamentária e gestão rotineira de bens e valores públicos importa em um elevado grau de discricionariedade para os agentes da Administração, de modo que os abusos cometidos em virtude dessa margem de liberdade não podem escapar ao controle da Corte de Contas.

Como se apontou, por mais que os programas previstos na lei de meios venham detalhados, sempre remanesce uma margem de liberdade aos gestores para concretizá-los. Cite-se, exemplificativamente, a atuação do TCU na fiscalização das obras de construção da sede do Ministério Público do Trabalho, em Brasília. Nesse caso, ainda que o programa orçamentário tivesse detalhado a construção em tela, restaria uma margem de liberdade quanto ao projeto básico e à escolha materiais que guarneceriam a edificação. O TCU ${ }^{352}$, nesse sentido, determinou uma extensa revisão do edital de licitação, tendo em vista a ocorrência de inúmeras irregularidades. Dentre elas, sobressai a escolha de materiais de alto requinte e custo que comporiam aspectos voluptuários da edificação. Notícias da imprensa, inclusive, apontavam que o edital previa a instalação de uma louça sanitária de alta tecnologia e preço, o Vaso sanitário shower toilet 8000-Geberit. ${ }^{353}$

Assim, evidenciaram-se impropriedades notórias, pois o exercício da competência discricionária deve se manter dentro de padrões razoáveis, morais e econômicos, pois a opção administrativa pelo luxo, pelo requinte e pela sofisticação não encontra respaldo ético. Em um cenário de recursos limitados, em que necessidades mais elementares não são atendidas a contento, o gasto de recursos públicos com materiais requintados não logra encontrar qualquer legitimidade. Dessa maneira, percebeu-se que o Tribunal não se furtou em questionar a conveniência e a oportunidade da escolha de

352 BRASIL. Tribunal de Contas da União. TC - 012.484/2007-2. Rel. Benjamin Zymler. j. 14. 11. 2007 e BRASIL. Tribunal de Contas da União. TC - 018.771/2009-4. Rel. Ana Arraes. j. 16. 11. 2011.

${ }^{353}$ Notícias veiculadas pela mídia apontam o custo de 23 mil reais para a unidade da louça sanitária. In: http://www.correiobraziliense.com.br/app/noticia/politica/2009/08/23/interna_politica,137093/index.shtml. Acesso em 23.07.2011. 
incrementos tão luxuosos, arvorando-se da competência constitucional de controlar a legitimidade dos atos de gestão.

No caso citado, a Corte de Contas não chegou a proferir a condenação dos gestores, pois as irregularidades apontadas foram sanadas e não houve qualquer prejuízo ao erário, mas o fato é que se o controle tivesse ocorrido a posteriori e as irregularidades restassem concretizadas, o juízo de condenação do Tribunal de Contas não poderia deixar de ser sancionador. É patente o despropósito do uso da discricionariedade administrativa para realizar, à custa dos cofres públicos, despesas luxuosas que em nada influenciam na escorreita prestação dos serviços públicos. Guarnecer um prédio público com louça sanitária de alta tecnologia e custo não encontra qualquer justificativa aceitável, invocando um severo julgamento de reprovação por afrontar princípios basilares da Administração como os da moralidade e da razoabilidade.

Do exemplo citado pode-se depreender que o controle de legitimidade exercido pelo Tribunal de Contas possibilitou a avaliação do mérito da atuação discricionária dos administradores públicos, contrastando-a em face de valores éticos e princípios constitucionalmente reconhecidos que, por sua vez, evidenciaram o desacerto das escolhas adotadas.

Registre-se, também, que o Tribunal de Contas não invadiu critérios de conveniência e oportunidade que implicariam na definição política da despesa pelo orçamento. In casu, não caberia ao Tribunal de Contas afirmar que a construção de um prédio seria ilegítima, pois o julgamento da definição orçamentária da despesa encerra-se na competência própria do Legislativo. Entretanto, uma vez fixado o gasto pela lei orçamentária, cabe à Corte de Contas perquirir sobre a legitimidade dos atos de administração - os discricionários, inclusive - que visam dar concretude aos programas e ações previstos na lei de meios.

No entanto, o âmbito da fiscalização da legitimidade pelo Tribunal de Contas revela-se tão abrangente quanto a larga amplitude que a atuação administrativa assume no tocante às finanças públicas.

Vale consignar que a Administração não se limita a escolher, discricionariamente, elementos acessórios quando da efetivação do programa definido orçamentariamente. Por vezes, a dotação orçamentária apresenta-se de tal modo genérica que a Administração se vê obrigada a desenvolver projetos e atividades que viabilizam a 
concretização racional da despesa orçamentária. Fala-se, nesse sentido, na discricionariedade da Administração em formular políticas públicas. ${ }^{354}$

Segundo Eduardo Mendonça:

"A medida da discricionariedade é dada pelo legislador. No âmbito do orçamento, isso significa que as dotações poderão ser detalhadas, restringindo a atuação do administrador. Poderão também ser genéricas, deslocando boa parte da competência decisória para o momento da execução.” (...) "as escolhas fundamentais são mantidas na via deliberativa do orçamento, alimentada pelas propostas do Poder Executivo. Ao mesmo tempo, como resultado desse processo deliberativo, será possível atribuir ao administrador participação importante na definição das políticas públicas específicas. Participação para concretizar - o que pode envolver escolhas fundamentadas dentro de balizas jurídicas mais ou menos amplas - mas não para ignorar a decisão orçamentária. „355

A visão do autor não deixa de ser acertada. Ora, o Executivo e o Legislativo traçam finalidades e diretrizes por meio dos programas orçamentários, estes, por sua vez, não são, em todos os casos, minudenciados e detalhados de modo a indicar uma conduta precisa. Essa realidade demonstra que há um espaço a ser integrado, discricionariamente, pelo administrador público quando da execução orçamentária, pois a efetivação de muitas das dotações reclama a definição de políticas públicas que deverão estabelecer os meios mais adequados para satisfazer os objetivos perseguidos pelos programas orçamentários.

\footnotetext{
354 "a medida decorrente da dotação orçamentária deverá ser cumprida, na extensão imposta por seu conteúdo. Se este for específico, a conduta devida já estará determinada. Caso institua um programa de ação, caberá ao administrador definir medidas concretas para realizá-lo. MENDONÇA, Eduardo. Da faculdade de gastar ao dever de agir: o esvaziamento contramajoritário das políticas públicas. In: SARLET, Ingo Wolfang; TIMM, Luciano Benetti (orgs.). Direitos fundamentais. Orçamento e "reserva do possivel". $2^{\mathrm{a}}$ ed. Porto Alegre: Livraria do Advogado, 2010. p. 401.

${ }^{355}$ Ibid. p. 400 e 401.
} 
É reconhecida, assim, uma vinculação imprescindível entre políticas públicas e orçamento, não só pelos contornos fundamentais que o programa confere à política pública prospectiva, mas, sobretudo, pela constatação de que de nada adiantaria formular políticas públicas se elas não encontrassem o respaldo orçamentário para o seu custeio. José Reinaldo de Lima Lopes ${ }^{356}$ argumenta com precisão que: "para a compreensão das políticas públicas é essencial compreender-se o regime das finanças públicas." e "Sem os planos e sem os orçamentos, nada de política pública pode ser implementado".

Mas não obstante as balizas orçamentárias quanto ao custeio e a configuração elementar da política pública, é certo reconhecer que o ordenamento não deixa de limitar a discrição do administrador quando da formulação das medidas de concretização do programa orçamentário.

Advoga-se, nesse sentido, que o processo de determinação das políticas públicas deve levar em conta parâmetros constitucionais que conferem validade material à atuação administrativa. Na atualidade, vários autores ${ }^{357}$ defendem a conformação das políticas públicas com os ditames constitucionais, em prejuízo da ampla discricionariedade da Administração. Dentre os autores destacam-se as lições de Leonel Pires:

"para que as políticas públicas possam desvelar um Estado Democrático de Direito, o conjunto de sentidos da tradição do constitucionalismo moderno aparece como via de acesso crucial. Destarte, tal constitucionalismo há de ser funcionalizado como fundamento hermenêutico de tais programas de ação governamental, pois nenhuma prática administrativa poderia estar divorciada dessas indicações empíricas, sob pena de faltar-lhes uma autêntica legitimidade."358

\footnotetext{
${ }^{356}$ LOPES, José Reinaldo de Lima. Judiciário, democracia e políticas públicas. Brasília: Revista de Informação Legislativa, Brasília, v.31, n. 122, mai/jun, 1994, p. 258 e 259.

${ }^{357}$ Cf. BUCCI, Maria Paula Dallari. Direito Administrativo e Políticas Públicas. São Paulo: Saraiva, 2002. p. 247 a 251. BARCELLOS. Ana Paula de. Constitucionalização... p. 106. OLIVEIRA, Farlei Martins Riccio de. Controle de Legitimidade de Políticas Públicas: limites e possibilidades. Atlas: Revista de Direito Administrativo, Rio de Janeiro, v. 247, 2008. p. 68 a 70.

${ }^{358}$ OHLWEILER, Leonel Pires. Políticas Públicas e controle jurisdicional: uma análise hermenêutica à luz do Estado de Direito. In: SARLET, Ingo Wolfang; TIMM, Luciano Benetti (orgs.). Direitos fundamentais. Orçamento e "reserva do possivel". $2^{\mathrm{a}}$ ed. Porto Alegre: Livraria do Advogado, 2010. p. 327.
} 
O que se argumenta é que os administradores, ao projetarem as políticas públicas, não podem agir como se a Constituição não existisse e não os vinculasse. Quer-se que eles atentem, sobretudo, para a realização de direitos fundamentais estabelecidos na Lei Magna e que a atuação administrativa seja consentânea com princípios constitucionais, como os da moralidade e eficiência, que preconizam o dever de boa administração. Fora dessas condicionantes constitucionais, não se pode concluir pelo acerto dos projetos de ação. Em outros termos, sem aderir à normativa básica da Constituição, as políticas públicas padecerão de grave ilegitimidade e prestar-se-ão, simplesmente, para o mau emprego dos recursos públicos.

Nesse sentido, é mister indeclinável do Tribunal de Contas avaliar, por meio do controle de legitimidade, a constitucionalidade das políticas públicas. Ateste-se, particularmente, que a apuração da legitimidade recorre à verificação de certos princípios e diretrizes constitucionais de elevada abstração e conteúdo valorativo de modo que, muitas vezes, legitimidade e constitucionalidade se confundem.

Conforme exposição pretérita, a apuração da legitimidade pelo controle financeiro importa também em conferir a adequação de condutas com uma legalidade constitucionalmente qualificada. Precisamente, o controle de legitimidade faz com que mandados axiológicos constitucionalmente estabelecidos figurem como parâmetro de correção de condutas. Logo, toda a conduta financeira do Estado há de ser adequada com princípios constitucionais de elevada abstração e generalidade que, por sua vez, exigem a correção material da conduta do gestor público.

Portanto, caso a definição das políticas públicas pelos administradores fuja aos parâmetros de constitucionalidade, os recursos públicos restarão, consequentemente, mal empregados, reclamando uma sindicância de legitimidade por parte dos Tribunais de Contas.

Exemplo eloquente da atuação dos Tribunais de Contas no controle de legitimidade de políticas públicas é a Súmula $n^{\circ} 1$ do TCE de São Paulo, cujo teor prescreve: "Não é lícita à concessão de subvenção para bolsa de estudo e assistência hospitalar com caráter personalíssimo."359

\footnotetext{
${ }^{359}$ Note que a súmula emprega o termo "subvenção" de modo genérico dando-lhe a significação de "auxílio" ou "ajuda”. Ocorre que a subvenção social, definida pela Lei 4320 de 1964, é, por força de lei, concedida em
} 
Nos termos da referida súmula, podem se projetar as mais variadas políticas públicas no tocante à subvenção do ensino e da assistência hospitalar, todavia, elas não poderão ter caráter personalíssimo, ou seja, as políticas públicas deste jaez não podem adotar o critério pessoal como fator de identificação dos beneficiários da atuação estatal.

O raciocínio que subsidiou a edição da súmula é deveras procedente. Note que a administração não pode, sob pena de patente injustiça, subsidiar despesas hospitalares e de ensino de pessoas determinadas, sem adotar um critério ponderado de discriminação. Indiscutivelmente, a súmula se dirige àquelas políticas públicas cujo beneficiário é contemplado com a ação governamental em virtude de sua própria pessoa, inexistindo qualquer outro fator que justifique a concessão do benefício. ${ }^{360}$

Seria legítimo subvencionar o ensino ou despesas hospitalares em razão de alguma contingência material dos indivíduos, o que colocaria sob a tutela do Estado um grupo de pessoas que se encontram na mesma situação. O que se quer vedar, no entanto, é a indicação, com base em critério pessoal, deste ou daquele indivíduo para direcionar-lhe um benefício público, em detrimento dos demais.

Nesse caso, é patente que os princípios constitucionais da isonomia ${ }^{361}$ e da impessoalidade ${ }^{362}$ serviram de fundamento para que a Corte de Contas paulista fulminasse a política pública que concede subvenção com base em critério personalíssimo. A conjugação desses dois princípios impede que a Administração privilegie determinadas pessoas em detrimento de outras, ou que a atuação administrativa privilegie uma pessoa sem qualquer justificativa razoável.

Assim, quando o benefício destina-se a um indivíduo, única e exclusivamente em razão de sua pessoa, resta configurado um privilégio ilegítimo e claramente atentatório a valores albergados constitucionalmente, ensejando à Corte de Contas o dever de censurar a política pública e aplicar sanções aos responsáveis pela sua configuração.

caráter personalíssimo às entidades beneficiadas. Isso porque, para receber as subvenções, as entidades devem demonstrar a competência de bem gerir os recursos públicos de modo que a concessão dessa benesse financeira não dispensa a análise "pessoal" das entidades agraciadas.

${ }^{360}$ Cf. BANDEIRA DE MELLO, Celso Antônio. O conteúdo jurídico do princípio da igualdade. $3^{\circ}$ ed, $10^{\mathrm{a}}$ tr. São Paulo: Malheiros, 2002. Em resumo, o jurista apregoa que a isonomia importa em discriminações, todavia, estas só são lícitas quando há um caráter lógico entre a discriminação e o fator de discrímen, sendo certo, também, que a discriminação deve encontrar respaldo nos valores albergados pelo texto constitucional. ${ }^{361}$ No que toca ao princípio da isonomia, as lições de José Afonso da Silva apontam que as discriminações só são constitucionais quando os benefícios são outorgados às pessoas nas mesmas condições, ou quando a obrigação é imposta a todos os que ostentam as mesmas condições. SILVA, José Afonso. Curso... p. 227.

362 Conforme as lições de Maria Sylvia Di Pietro, o princípio da impessoalidade veda à Administração beneficiar ou prejudicar pessoas determinadas. DI PIETRO, Maria Sylvia. Direito...p. 67. 
Registre-se, por fim, que a análise de constitucionalidade de políticas públicas pelo Tribunal de Contas não se fundamenta na súmula 347 do $\mathrm{STF}^{363}$, que defere à Corte de Contas a possibilidade de apreciar a constitucionalidade das leis e dos atos normativos do Poder Público.

Isso porque, o controle de legitimidade de políticas públicas não importa na contestação de disposições normativas abstratas em face da Constituição, mas sim na fiscalização de atos administrativos concretos, que fixam ações materiais para viabilizar a execução orçamentária de dotações de caráter extremamente genérico.

Nesse sentido, ao rever a constitucionalidade de políticas públicas, o Tribunal não confronta dispositivos legais, sequer a lei orçamentária é contrastada. $\mathrm{O}$ aspecto sindicado, no caso, é a conduta dos gestores públicos na expedição de atos administrativos concretos que visam dar cumprimento às emanações legais. Não se trata, portanto, de rever a constitucionalidade de leis ou atos normativos, mas sim de analisar a aptidão dos atos de gestão administrativa em desvelar uma política pública que seja consentânea com as finalidades e diretrizes consignadas no Texto Maior.

De outro modo, a possibilidade da Corte de Contas rever a constitucionalidade de atos normativos tem sido fortemente contestada por fontes institucionais do controle de constitucionalidade. O Ministro Gilmar Ferreira Mendes, em sede de julgamento no STF, ventilou a hipótese de revisão da Súmula 347. ${ }^{364}$ Segundo ele, a súmula foi editada em 1963, época em que não havia o controle abstrato de normas em face da Constituição, o que, em tese, permitia aos Tribunais de Contas apreciar, difusamente, a inconstitucionalidade de lei ou ato normativo.

Todavia, recorda o citado Ministro, que a sistemática atual de controle de constitucionalidade restringe, de maneira radical, as possibilidades de controle difuso por parte de órgãos não-jurisdicionais, uma vez que o STF - e, em alguma medida, os Tribunais de Justiça dos Estados - firma-se como a instância definitiva do controle abstrato de normas. Logo, haveria grave insegurança jurídica caso mais de um órgão pudesse declarar, fora do caso concreto, a inconstitucionalidade de lei ou ato normativo.

Desse modo, não é acertado, muito menos conveniente, recorrer à Súmula 347 do STF para fundamentar o controle de constitucionalidade de políticas públicas pelo

\footnotetext{
363 Súmula 347 do STF: O Tribunal de Contas, no exercício de suas atribuições, pode apreciar a constitucionalidade das leis e dos atos do Poder Público.

${ }^{364}$ BRASIL. Supremo Tribunal Federal. MS 25888 DF- MC. Rel. Min. Gilmar Mendes. j. 23.03. 2006.
} 
Tribunal de Contas. Ressalte-se que a própria Constituição, ao prever o controle de legitimidade pelas Corte de Contas, já lhe conferiu competência para fiscalizar e julgar os atos relativos à gestão dos recursos públicos, possibilitando, nesse particular, contrastar os atos administrativos com princípios e diretivas constitucionais que servem de orientação ética aos administradores.

Resulta, portanto, despiciendo invocar a Súmula 347 do STF para subsidiar a competência da Corte de Contas na fiscalização da constitucionalidade dos atos de gestão administrativa dos bens e valores públicos.

\subsubsection{Os limites da atuação dos Tribunais de Contas em relação aos} atos discricionários.

O controle da legitimidade pelo Tribunal de Contas, ao franquear o exame do mérito administrativo, deve fundar-se em uma premissa inafastável, a saber: as faculdades discricionárias da Administração não podem ser prejudicadas, é necessário, antes, garantir ao administrador a liberdade de eleger, no caso concreto, a opção mais conveniente à satisfação das finalidades do interesse público.

Ou seja, a sindicância das Cortes de Contas não pode pretender substituir a vontade legítima da Administração, pois o contraste do mérito só tem sentido se for utilizado para coibir desvios e impropriedades. Observa, nessa linha, Juarez de Freitas:

"os atos discricionários são, sob certo aspecto, aqueles que mais densamente precisam ser sindicados, na busca da melhor solução. Não para espartilhar o bom agente público, nem para estabelecer o império do medo, menos ainda para instabilizá-lo exasperantemente (como o personagem ' $K$ ' do Castelo de Kafka), mas para, nas fronteiras da juridicidade, 
coibir os nefandos erros e as motivações destituídas da mínima consistência."365

Definitivamente, não compete ao Tribunal de Contas a administração da coisa pública. Sua função precípua é de outra índole, cabendo-lhe fiscalizar, apurar e coibir qualquer impropriedade na gestão dos recursos públicos. Se as Cortes de Contas censurassem escolhas provenientes do exercício legítimo da discricionariedade, haveria, certamente, invasão de competências, uma vez que a eleição, no caso concreto, da solução mais pertinente à consecução do interesse público é atribuição exclusiva da função administrativa.

Resulta, portanto, que o agir discricionário é, indiscutivelmente, prerrogativa da Administração; à Corte de Contas cabe apenas o controle. Nesse diapasão, a prudência do Tribunal de Contas para não interferir nas faculdades discricionárias deve ser redobrada, tendo em vista que sua tarefa sindicante é mais vigorosa e comporta um exercício contínuo de interpretação jurídica e de subsunção de fatos às normas. Assim, a aferição da legitimidade das escolhas discricionárias torna-se mais robusta e, consequentemente, mais propícia a desencadear um desbordamento dos limites de sua atuação.

Nesse sentido, é imprescindível sublinhar algumas restrições impostas aos Tribunais de Contas quando do controle da discricionariedade administrativa no claro intuito de preservar as faculdades discricionárias do gestor público.

Um primeiro limite à sindicância dos Tribunais de Contas decorre da dualidade dos regimes de apuração de contas, mediante controle externo. Consignou-se alhures que as competências das Cortes de Contas volta-se ao quotidiano da Administração, verificando a correção de atos administrativos singularizados expedidos em vista da concretização do orçamento e da gestão dos bens e valores públicos.

Dessa maneira, toda a discricionariedade política exercida pelo Chefe do Executivo no tocante à definição dos fins últimos da atividade financeira fica subtraída ao controle exercido pelos Tribunais de Contas. Mais precisamente, a fixação das receitas e despesas, a previsão dos programas orçamentários, o uso do contingenciamento e dos

${ }^{365}$ FREITAS, Juarez. Discricionariedade... p. 42. 
mecanismos de flexibilidade orçamentária não estão sujeitos ao julgamento do Tribunal de Contas, mas submetem-se ao juízo político do Parlamento.

No campo do julgamento político, a atribuição máxima dos Tribunais de Contas é, nos termos do art. 71, I, da CF, emitir um parecer prévio sobre condução global das finanças públicas. Todavia, esse parecer prévio é meramente opinativo e não tem o condão de vincular a apreciação dos parlamentares acerca das contas prestadas pelo Chefe de Executivo. Desse modo, não se pode afirmar que Tribunal de Contas está constitucionalmente habilitado para julgar critérios políticos de conveniência e oportunidade que determinaram a adoção dos fins e dos meios inerentes à atuação financeira do Estado.

Um segundo limite, esse sim relativo à competência própria dos Tribunais de Contas, consiste em preservar as escolhas administrativas legítimas. De fato, o controle da legitimidade permite ao Tribunal de Contas analisar o mérito das opções discricionárias, contudo, essa competência supõe que os agentes de controle reconheçam que há uma pluralidade de opções igualmente legítimas e qualquer delas pode ser adotada pelo administrador, sem qualquer prejuízo à correção da atividade administrativa.

Celso Antônio Bandeira de Mello, apesar de enfatizar que a discricionariedade reclama a adoção da solução ótima, perfeita e adequada, reconhece que no exercício discricionário "há o problema de não se poder saber qual é a solução ótima". ${ }^{366}$ Afirma o autor: "Em suma: a providência ideal em muitas situações é objetivamente incognoscível. Poder-se-á tão somente saber que será uma que se contenha dentro de um número limitado de alternativas e que se apresente razoável no caso concreto." 367

Esse panorama é, sem dúvida, o calcanhar de Aquiles do controle da discricionariedade. Em inúmeros casos não há por parte da Administração e, muito menos, por parte dos organismos controladores, uma certeza objetiva sobre qual escolha representa a melhor opção para satisfazer o interesse público. O certo é que há opções que, seguramente, não se pautam pelo prisma da correção e outras que se colocam dentro uma pluralidade de medidas igualmente válidas e legítimas.

Logo, se é certo que o gestor não pode adotar uma medida arbitrária, sofrível, incorreta, é certo, igualmente, que ele não está vinculado a eleger uma única

\footnotetext{
${ }^{366}$ BANDEIRA DE MELLO, Celso Antonio. Discricionariedade... p. 42.

${ }^{367}$ Ibid. p. 43.
} 
opção legítima dentre várias - também, legítimas - que se lhe apresentam como solução plausível.

Nesses casos, em que há um número relativamente variado de opções válidas, a Corte de Contas deve reconhecer a legitimidade da adoção de qualquer delas, sem presumir que uma reputa-se mais conveniente que outra. Recorde-se que a eleição proveniente da discricionariedade é uma função precipuamente administrativa, fugindo à competência dos órgãos de controle, de tal modo que o Tribunal de Contas não pode pretender censurar a escolha de uma opção legítima por entender ser mais conveniente outra, igualmente legítima.

A celeuma, porém, não é tão simples quanto parece. Ocorre que a prática efetiva do controle financeiro pode revelar um grande número de casos complexos em que há um limite muito tênue entre a opção legítima e a opção ilegítima. Haverá, certamente, hipóteses em que a ilegitimidade se afigura flagrante: a eleição do administrador é tão absurda e o intento de desprestigiar as finalidades do interesse público é tão evidente que à Corte de Contas não resta alternativa, senão censurar o exercício viciado da discrição administrativa. Por outro lado, não raro, acontecem situações em que há fundada incerteza acerca da correção da atividade discricionária, sendo o teor dessa dúvida potencializado pelo fato de que pode existir mais de uma opção válida.

Sobre esse particular, Celso Antonio relaciona o exercício da discricionariedade com as chamadas "zonas de certeza", segundo a qual: "haverá sempre uma 'zona de certeza positiva', na qual ninguém duvidará do cabimento da aplicação do conceito, uma 'zona circundante', onde justamente proliferarão incertezas que não podem ser eliminadas objetivamente, e, uma 'zona de certeza negativa', onde será indispensavelmente seguro que descabe a aplicação do conceito." 368

Transportando as lições do autor para o contexto do controle da discricionariedade, é possível afirmar que haverá sempre uma zona de certeza positiva na qual o exercício da discricionariedade será, a toda evidência, legítimo, pois consentâneo com os padrões correção expressos pelo ordenamento, e, de outro modo, existirá uma zona de certeza negativa onde, inequivocamente, a discrição é, por diversas razões, ilegítima. Porém, há, ainda, uma zona de incertezas onde o caráter multifacetado das circunstâncias que envolvem o caso não deixa claro se opção administrativa reputa-se correta.

${ }^{368}$ BANDEIRA DE MELLO. Curso... p. 399. 
Nesse sentido, com alguma habitualidade colocam-se sob a apreciação da Corte Contas dilemas acerca da legitimidade ou ilegitimidade das condutas administrativas. São de fato dilemas, pois o juízo de correção que sobre eles recais não é, desde logo, inequívoco. Revelam, antes de tudo, situações limítrofes entre o erro e o acerto, em que a dúvida é a primeira conclusão sensata que se pode fazer sobre o caso.

Assim, resta o questionamento sobre como a Corte de Contas deve proceder em casos de interpretação mais apertada, nos quais paira a dúvida sobre a correção dos atos discricionários.

O primeiro movimento das Cortes de Contas deve ser - não só para os casos mais tormentosos, mas para todos aqueles que envolvem o contraste do mérito - evidenciar as peculiaridades do caso concreto, pois apenas a partir das circunstâncias fáticas é que se pode julgar o acerto ou o desacerto da opção discricionária. Segundo Celso Antonio Bandeira de Mello:

"Não se pode examinar a existência da discricionariedade ou de sua extensão buscando-a simplesmente no exame da lei que porventura a contemple porque é imprescindível analisar o caso concreto, pois a discrição ao nível da norma é apenas uma condição necessária, mas não suficiente, para que irrompa ou para dimensionar-lhe a extensão.",369

Essas lições de Celso Antônio veiculam orientações preciosas, pois somente as características próprias do caso concreto trazem os elementos que permitem ao administrador optar por esta ou aquela medida, de tal modo que a legitimidade da escolha somente pode ser corretamente avaliada sob a perspectiva dos fatos que a ensejaram. A análise da discricionariedade baseada apenas na dogmática jurídica e desvencilhada dos reclames fáticos não é suficiente para conduzir a um juízo acertado, impondo-se, nesse particular, à Corte de Contas uma reflexão detida sobre as circunstâncias nas quais se deu o exercício discricionário.

${ }^{369}$ BANDEIRA DE MELLO, Celso Antonio. "RELATIVIDADE" da Competência Discricionária. Revista Eletrônica de Direito do Estado. Salvador, Instituto de Direito Público da Bahia, no 5, jan/fev/mar, 2006. p. 8. Disponível em: http://www.direitodoestado.com. Acesso em 13. 08.2012. 
Ainda assim, pode ocorrer que dúvida não seja sanada a partir de uma análise criteriosa dos fatos concretos, exigindo-se ao Tribunal de Contas uma verdadeira síntese dialética do caso, o que lhe permitirá chegar a uma conclusão razoável sobre a legitimidade ou ilegitimidade do ato administrativo.

Como se afirmou alhures, a aferição da legitimidade reclama, não poucas vezes um esforço dialético cujo objetivo é, sem dúvida, encontrar a verdade por meio da apreciação da realidade. Nesses casos, existe um ímpeto argumentativo no qual se sopesam teses contrárias no intuito de chegar a uma conclusão real, verdadeira e objetiva.

Veja, por exemplo, o caso do uso das cotas de passagens aéreas pelos parlamentares. O Congresso destina um numerário para que os parlamentares possam custear suas viagens, podendo-se vislumbrar, nesses casos, uma esfera discricionária quanto ao destino e o motivo específico da viagem. Todavia, qualquer que seja o motivo e o destino da viagem, é imprescindível que eles guardem relação com o exercício do mandato e com a função parlamentar, pois os cofres públicos não podem subsidiar interesses privados dos agentes de Estado.

Ocorre, porém, que muitos parlamentares - e, inclusive, seus familiares usaram esse dinheiro para financiar viagens turísticas, pervertendo a finalidade pública das verbas destinadas à compra de passagens. Não obstante a argumentação de alguns deputados, alegando que a ausência de norma proibitiva sobre a compra de passagens autorizava o uso desse dinheiro para qualquer fim, o $\mathrm{TCU}^{370}$ determinou o ressarcimento dos cofres públicos, invocando que o uso de verbas públicas em finalidade que não diz respeito ao exercício do cargo representava afronta à moralidade. ${ }^{371}$

Nessa hipótese, a ilegitimidade da despesa é flagrante e óbvia, tornando menos complexo o juízo de legitimidade da Corte de Contas. Qualquer homem dotado de um senso moral mediano percebe que os cofres públicos não podem custear viagens recreativas de quem quer que seja. Se o parlamentar recebe alguma ajuda de custo, esta deve ser empregada, exclusivamente, no interesse do mandato e da função pública que ele exerce, sob pena de provocar grave prejuízo aos recursos do erário.

Entretanto, pode surgir, em relação ao exemplo citado, uma nuance cuja legitimidade não é tão facilmente determinável. Um deputado ventilou a possibilidade de

\footnotetext{
${ }^{370}$ BRASIL. Tribunal de Contas da União. TC 009.647/2009-4. Rel. Raimundo Carreiro. j. 14.10. 2009.

${ }^{371}$ Registre-se, todavia, que os parlamentares, individualmente, sujeitam-se à competência sindicante dos Tribunais de Contas, pois gerenciam bens e valores públicos como, por exemplo, as chamadas verbas de representação.
} 
que as milhagens acumuladas com os vôos custeados pelo Congresso deveriam ser repassadas à Casa Legislativa, e não poderiam, portanto, serem usadas para fins particulares dos deputados e seus familiares. ${ }^{372}$

Nesse aspecto, a questão sobre a utilização das chamadas "milhagens" não deixa de suscitar dúvidas acerca da legitimidade.

De um lado, seria possível afirmar que as milhagens deveriam pertencer ao Congresso, pois foram amealhadas como uso de passagens aéreas subsidiadas por recursos públicos. Não foi o patrimônio particular do deputado que propiciou o benefício da "milhagem", mas sim o patrimônio público empregado para financiar o exercício do mandato parlamentar. A esfera patrimonial privada do parlamentar não pode privilegiar-se à custa dos cofres públicos, sob pena de afrontar o princípio que veda o enriquecimento sem causa, logo, a legitimidade do uso de tais milhagens só se comprova se elas forem usadas no interesse da função parlamentar e não em finalidades privadas.

Por outro lado, poderia se argumentar que as milhagens acumuladas com passagens custeadas pelo Congresso podem ser usadas como o parlamentar bem entender, sem qualquer prejuízo à legitimidade. Primeiro porque as milhagens têm natureza privada e promocional, não são, portanto, de concessão obrigatória pela empresa aérea. Representam, dessa maneira, um incremento acidental destinado aos parlamentares, cujo deferimento não depende da origem pública ou privada do dinheiro que deu causa ao benefício. Depois, as milhagens são concedidas em caráter pessoal, ou seja, pertencem, contratualmente, às pessoas que usaram os serviços das companhias aéreas e não às instituições públicas que foram a causa remota do benefício e, também, há outros mecanismos particulares - como o uso de cartões de créditos - que cumulam milhagens, sendo impossível distinguir se a milhagem foi amealhada com a compra de passagens aéreas ou com o uso desses outros mecanismos. Desse modo, não haveria como afirmar que as milhagens deferidas aos parlamentares pertencem ao Congresso, visto que se tratam de benefício privado, eventual e concedido, contratualmente, em caráter personalíssimo ao usuário do serviço aéreo. ${ }^{373}$

\footnotetext{
${ }^{372}$ http://congressoemfoco.uol.com.br/noticias/memoria/tres-deputados-devolveram-dinheiro-de-passagens/ Acesso: 23.07.2012.

${ }^{373}$ Essa foi a argumentação da direção da Câmara para deixar de exigir as milhagens dos parlamentares. Cf. http://congressoemfoco.uol.com.br/noticias/memoria/tres-deputados-devolveram-dinheiro-de-passagens/ Acesso: 23.07.2012.
} 
Destarte, é possível verificar a existência de argumentos consistentes que pendem tanto para a legitimidade, quanto para a ilegitimidade do uso particular de milhagens aéreas amealhadas com passagens compradas por recursos públicos. A celeuma, por certo, não é tão simples de ser resolvida, cabendo à Corte de Contas empreender um esforço dialético para concluir pela correção ou incorreção deste caso particular.

Entretanto, o exemplo citado soma-se a outros tantos nos quais prevalecem dúvidas consistentes acerca da correção dos atos de gestão financeira, em especial aqueles expedidos mediante competência discricionária. Toda essa problemática, torna o controle de legitimidade exercido pelo Tribunal de Contas sobremaneira complexo, pois além da preocupação em garantir o exercício livre das faculdades discricionárias, haverá casos em que não existirá uma certeza inequívoca sobre a regularidade ou irregularidade da atuação administrativa, exigindo da Corte de Contas um empenho hercúleo no sentido de proferir um juízo adequado sobre os fatos postos a sua análise.

Nota-se, assim, que o exame da legitimidade dos atos discricionários deve ser cuidadoso, prudente e preocupado com a preservação das faculdades discricionárias da Administração Pública. Além de reconhecer a existência de uma pluralidade de soluções legítimas para determinado caso, a Corte de Contas deve atentar para hipóteses mais tormentosas, nas quais emana uma dúvida fundada sobre o acerto da conduta administrativa. Nesse particular, a análise dialética se mostra fundamental, pois somente a partir dela é possível sopesar critérios argumentativos que devem conduzir, obrigatoriamente, a uma conclusão verdadeira, objetiva e, fundamentalmente, atenta à garantia das atribuições discricionárias da Administração.

\subsubsection{O julgamento do Chefe do Executivo pelo Tribunal de Contas.}

Como se expôs, ao Chefe do Poder Executivo reserva-se um julgamento de índole política pelo Legislativo, todavia, esse julgamento não se debruça sobre fatos isolados, mas analisa todo um conjunto de ações, e, porque não dizer de omissões, que orientaram a condução política da atividade financeira do Estado. Sobretudo, como já se fez notar, o Legislativo julga atos essencialmente discricionários, que não se submetem, aprioristicamente, a um juízo peremptório de certo ou errado, mas que podem redundar no 
sucesso ou no fracasso do direcionamento da atuação financeira concebida pelo Chefe do Executivo.

Entretanto, essa reserva constitucional que prevê ao Chefe do Executivo um julgamento político em matéria financeira não faz concluir, obrigatoriamente, que o Tribunal de Contas está impedido de sindicar e de julgar o Chefe do Poder Executivo. Ora, o julgamento político relaciona-se ao direcionamento global das finanças públicas e procede a uma avaliação de desempenho das finalidades e diretrizes encampadas pelo governante. Já a Corte de Contas debruça-se sobre o quotidiano da gestão pública perquirindo sobre a correção de atos administrativos concretos. Assim, caso o Chefe do Executivo atue diretamente na administração dos recursos públicos, expedindo, nessa condição, atos relativos à execução orçamentária e à gestão de bens e valores, ele estará, inevitavelmente, sujeito às competências do Tribunal de Contas.

Não é difícil identificar inúmeros casos nos quais o Chefe do Executivo exerce a administração direta dos recursos públicos. Nesse particular, ele age, motu proprio, como ordenador de despesa e executor de programas de governo, responsabilizando-se diretamente por eventuais impropriedades que venham macular os atos de gestão administrativa.

Destarte, o Tribunal de Contas não pode se furtar em exercer sua atribuição constitucional de julgar os administradores e responsáveis por bens e valores públicos, ainda que estes ocupem o cargo de Chefe do Executivo. José de Ribamar Caldas Furtado apregoa que: "o regime do julgamento de contas será determinado pela natureza dos atos a que elas se referem, e não por causa do cargo ocupado pela pessoa que os pratica. Para os atos de governo haverá o julgamento político; para os atos de gestão o julgamento técnico" 374

Desse modo, pouco importa a natureza do cargo que o agente assume: se ele gere, diretamente, bens e recursos públicos estará sujeito ao juízo do Tribunal de Contas. O fato de que a Constituição prevê um julgamento político ao Chefe do Executivo, não o imuniza da possível sindicância das Cortes de Contas quando os fatos versarem sobre a gestão corrente de bens e valores públicos.

${ }^{374}$ FURTADO, José de Ribamar Caldas. Os regimes... p. 75. 
O STF, nessa linha, não tem se furtado em confirmar condenações do TCU sobre a atuação de prefeitos municipais na gestão verbas federais, conforme se depreende desse ementário:

"PREFEITO MUNICIPAL. CONVÊNIO COM GOVERNO FEDERAL. PRESTAÇÃO DE CONTAS.CONDENAÇÃO IMPOSTA PELOTRIBUNAL DE CONTASDA UNIÃO. ALEGADA VIOLAÇÃO AOS ARTS. 5. ${ }^{\circ}$ E 37 DA CONSTITUIÇÃO FEDERAL. A Corte de Contas, levando em consideração o montante das verbas federais repassadas ao Município de Aquidabã - SE durante a gestão do impetrante, concluiu por sua responsabilidade na administração de tais recursos, não havendo falar em contrariedade aos princípios da isonomia, legalidade, moralidade e impessoalidade pelo simples fato de o convênio em questão haver sido firmado pelo Prefeito antecessor. Mandado de segurança indeferido., 375

Nesse caso, embora se possa vislumbrar alguma particularidade quanto ao fato do TCU julgar um agente de outra esfera federativa, é importante ressaltar que a previsão do julgamento das contas do prefeito pelo Legislativo Municipal não foi capaz de elidir o juízo de reprovação da Corte de Contas federal, tendo em vista que o prefeito atuou diretamente na administração de verbas federais e lesionou, com a sua gestão, os cofres da União.

José de Ribamar Caldas Furtado ${ }^{376}$ esclarece, de seu turno, que o julgamento do Chefe do Executivo pelo Tribunal de Contas ocorre, quase que exclusivamente, em pequenos municípios nos quais a estrutura administrativa faz com que os Prefeitos funcionem, também, como ordenadores de despesa. Nos Estados, na União e em Municípios maiores o escalonamento da estrutura administrativa acaba atribuindo aos Chefes do Executivo funções claras de direção política, deixando a administração propriamente dita aos servidores subalternos.

Logo, somente diante de Administrações simplificadas, como as de pequenos municípios, é que restaria aos Chefes do Executivo a gestão direta de recursos públicos e, consequentemente, a possibilidade de serem julgados pelos Tribunais de Contas. Nesses termos, o próprio STJ reconheceu às Cortes de Contas a competência para

\footnotetext{
${ }^{375}$ BRASIL. Supremo Tribunal Federal. MS 24328/DF. Rel Min. Ilmar Galvão. j. 06.12.2002.

${ }^{376}$ FURTADO, José de Ribamar Caldas. Os regimes... p. 75.
} 
julgar, diretamente, os prefeitos quando agirem na condição de ordenadores de despesas. Dispõe a ementa da referida decisão:

“ADMINISTRATIVO - TRIBUNAL DE CONTAS: FUNÇÕES (ARTS. 49, IX, C/C 71 DA CF/88).1. O Tribunal de Contas tem como atribuição apreciar e emitir pareceres sobre as contas públicas (inciso I do art. 71 da CF/88), ou julgar as contas (inciso II do mesmo artigo).2. As contas dos agentes políticos - Prefeito, Governador e Presidente da República são julgados pelo Legislativo, mas as contas dos ordenadores de despesas são julgados pela Corte de Contas.3. Prefeito Municipal que, como ordenador de despesas, comete ato de improbidade, sendo julgado pelo Tribunal de Contas. 4. Recurso ordinário improvido. ${ }^{377}$

Deve-se argumentar, entretanto, que a competência constitucional do Tribunal de Contas para julgar qualquer administrador ou responsável por bens e valores públicos não alcança, tão somente, os prefeitos municipais, antes, os Chefes do Executivo de todas as esferas da Federação deverão se submeter ao julgamento das Cortes de Contas sempre que administrarem diretamente os recursos do erário, bem como quando derem causa direta a qualquer desfalque ou extravio no patrimônio público.

Isso porque não só nos pequenos municípios há a administração direta de recursos pelos Chefes do Executivo. Há, por exemplo, o caso dos gastos pessoais realizados diretamente pelos Prefeitos, Governadores e Presidentes, muitas vezes pela via dos chamados "cartões corporativos" que são fontes de custeio até certo ponto ilimitadas e muito pouco transparentes. Assim, a gestão de recursos em despesas pessoais pelos agentes políticos, que se notabilizam pelos excessos e imoralidades, não podem escapar à sindicância e à eventual reprovação pelos Tribunais de Contas. ${ }^{378}$

Nesses casos, a fiscalização quanto à legitimidade se revelaria um importante instrumento para verificar qualquer impropriedade na gerência de bens e recursos públicos pelos Chefes do Executivo. A sindicância de moralidade, que a fiscalização quanto à legitimidade franqueia, permitiria um controle substantivo sobre os gastos pessoais dos governantes que são, no mais das vezes, realizados de modo arbitrário

377 BRASIL. Superior Tribunal de Justiça. RO MS 13499/CE. Rel. Min. Eliana Calmon, $2^{\text {a }}$ turma. j. 13.08.2002.

${ }^{378}$ Cf. HARADA, Kiyoshi. Cartões corporativos infringem princípios de Direito Financeiro. In: Âmbito Jurídico, Rio Grande, 2008 Disponível em: http://www.ambitojuridico.com.br/site/index.php?n_link=revista_artigos_leitura\&artigo_id=2757. Acesso em 28/06/2011. 
e sem uma maior preocupação com a prestação de contas. Necessidades requintadas e desarrazoadas dos detentores do Poder não merecem, sob o prisma ético, o custeio público, e, uma vez constatadas, tais incorreções devem ensejar o julgamento condenatório por parte da Corte de Contas.

Destarte, a atuação direta dos Chefes do Executivo na gestão de bens e recursos públicos não está subtraída da competência julgadora dos Tribunais de Contas. Se a conduta dos Chefes do Executivo revelarem a administração corriqueira do patrimônio público e a execução direta dos programas orçamentários, eles estarão, seguramente, sob o juízo do Tribunal de Contas. Do contrário, se o Chefe do Executivo atuar tão somente na linha do direcionamento político, veiculando finalidades e diretrizes gerais, ele só se submeterá ao julgamento político perpetrado pelo Poder Legislativo. 


\section{A FISCALIZAÇÃO FINANCEIRA QUANTO À LEGITIMIDADE MEDIANTE CONTROLE INTERNO.}

Se o controle da legitimidade, mediante controle externo suscita inúmeras controvérsias sobre o enfrentamento do mérito administrativo, é bem verdade que a análise de legitimidade pelos órgãos de controle interno não traz consigo maiores perplexidades.

Há, de fato, duas razões muito evidentes que facilitam a sindicância de legitimidade pelo sistema de controle interno. O primeiro motivo é que no controle interno não há interferência externa capaz de substituir a decisão do administrador público. Nesta espécie de controle, como indica a nomenclatura, a Administração fiscaliza a si própria, inexistindo ingerências de órgão ou Poder estranho à estrutura administrativa.

Assim, se no controle externo deve ser sublinhada a preocupação institucional de se preservar a esfera discricionária do gestor para impedir que órgãos estranhos intrometam-se na função privativa da Administração, no controle interno tal preocupação inexiste, pois qualquer ingerência advirá dos quadros da própria Administração, não havendo que se cogitar sobre intromissões indevidas de um Poder ou órgão sobre outro.

Ocorre que, mediante o exercício do controle interno, toda ingerência não só será permitida - dada a ausência de intromissão externa - como também será desejável na medida em o controle interno propicia à Administração a possibilidade de avaliar, constantemente, a eficácia e a eficiência de sua gestão financeira.

Conforme explicita a CF de 1988, no art. 74, a avaliação de resultados, metas e programas é finalidade institucional dos órgãos de controle interno. Essa atribuição constitucional acaba por erigir o sistema de controle interno em polo de orientação estratégica da gestão dos recursos públicos, uma vez que, consoante as avaliações das controladorias internas, a atuação ineficiente, ineficaz e grosseira deve ser revista e não mais repetida.

José Mauricio Conti e Andre Carvalho apregoam, nesse sentido, que o controle interno: 
"Tem a finalidade de constatar a eficiência, efetividade eficácia, legalidade e legitimidade das atividades administrativas e financeiras exercidas pelos diversos componentes dos órgãos em questão, realizando o acompanhamento das políticas traçadas pelo gestor, e dar subsídios para correções, ajustes e aperfeiçoamentos voltados a atingir as metas além de fornecer informações úteis e necessárias para a tomada de decisões". 379

Segue-se, portanto, que as finalidades do sistema de controle interno resultam fundamentais à consecução de boas práticas administrativas. Cabe, sobretudo, ao controle interno evidenciar as causas que conduziram aos resultados pífios e ao não atendimento das metas estabelecidas de modo a indicar à Administração a necessidade de corrigir as impropriedades apontadas com o escopo de imprimir na gestão dos recursos públicos o maior nível de eficiência possível.

Isso, sem dúvida, possibilita às controladorias internas apreciar a aptidão das escolhas administrativas em alcançar a maximização dos resultados e atingir as metas estabelecidas nos planos e programas orçamentários. Nesse sentido, vale ressaltar que a própria configuração constitucional do sistema de controle interno lhe apregoa finalidades que exigem uma minuciosa investigação da discricionariedade administrativa no intuito de desvelar o real desempenho da gestão pública.

Vislumbra-se, desse modo, a segunda razão pela qual o controle interno pode, sem problemas, enfrentar o mérito administrativo. Eis que os órgãos de controle interno são, por natureza, destinados a avaliar e retificar a gestão pública dos recursos financeiros, perquirindo, para tanto, sobre a legitimidade das decisões relativas à atuação financeira do Estado.

A feição institucional do controle interno lhe defere, como um instrumento indispensável, a possibilidade de contraditar escolhas e decisões que, por certo, influem na performance da atuação financeira do Estado. A legitimidade surge, na espécie, como padrão de correção próprio do controle interno, uma vez que o contraste da mera

${ }^{379}$ CARVALHO, André de Castro e CONTI, José Maurício. O Controle Interno na Administração Pública Brasileira: qualidade do gasto público e responsabilidade fiscal. Direito Público. Ed. Síntese/IDP: Porto Alegre/Brasília, v. 37, jan/fev, 2011. p. 207. 
legalidade não se mostraria hábil para avaliar o rendimento material da gestão pública. Reforçam, nessa linha, as lições de Marcelo Neves:

“Com a adoção dessa nova sistemática de controle interno passando de um mero órgão executor de auditorias de conformidade ('compliance') para a realização de auditorias de natureza operacional (desempenho) - ganha a Administração não um mero fiscal, mas um verdadeiro parceiro. Sabemos, contudo, que essa alteração pode gerar, inicialmente, uma relativa insegurança para os órgãos de execução, que será pouco a pouco dissipada com a ênfase que deve ser dada pelas Controladorias no trabalho de assessoramento à gestão, bem como na elaboração de avaliação de resultado, o que servirá como elementos de indiscutível apoio às tomadas de decisões dos gestores. Dessa forma, reforça-se o eixo do trabalho de controle interno para além do campo da legalidade, incorporando a legitimidade". 380

Desse modo, a sindicância da legitimidade, melhor destinada a avaliar os aspectos de desempenho da gestão pública, abre campo para que o sistema de controle interno possa verificar o mérito da ação administrativa no sentido de apontar as deficiências operacionais que levaram à ineficiência programática dos gastos públicos.

Consoante disposição do art. $74 \mathrm{da} \mathrm{CF}$, as finalidades constitucionais consignadas ao controle interno colocam ênfase na análise de resultados, formatando um controle voltado, essencialmente, à gestão operacional, o que importa, consequentemente, na análise das escolhas de mérito efetuadas pelos gestores públicos.

Não há, portanto, no particular do controle interno uma preocupação em preservar a esfera discricionária do gestor público, pois institucionalmente essa espécie de controle volta-se a avaliar se eleição de programas, planos e atividades mostraram-se

\footnotetext{
${ }^{380}$ NEVES, Marcelo. O novo paradigma para os órgãos de controle interno: da auditoria de conformidade (campo da legalidade) para a auditoria operacional de natureza eminentemente preventiva. Fórum de Contratação e Gestão Pública, Belo Horizonte, ano 6, n. 67, jul, 2007. p. 41.
} 
competentes para produzir resultados satisfatórios e para atender as metas previamente consignadas pelo planejamento financeiro.

Assim, de todo exposto, pode-se concluir que a análise de legitimidade mediante controle interno não suscita grandes problemas em relação à discricionariedade. Primeiro porque é da natureza dos órgãos de controle interno rever, corrigir e coibir as ações ineficientes, bem como aquelas que não se mostram condizentes com padrões éticos indeclináveis, o que lhes permite aferir, diretamente, os critérios de conveniência e oportunidade que orientaram a gestão administrativa. Em segundo lugar, o fato de que o controle interno está inserido dentro do âmbito da Administração elide qualquer perplexidade relativa à preservação da discricionariedade administrativa de eventuais ingerências indevidas por parte dos órgãos de controle estranhos à estrutura administrativa. 


\section{A FISCALIZAÇÃO FINANCEIRA QUANTO À LEGITIMIDADE: AS EMPRESAS ESTATAIS, AS RENÚNCIAS DE RECEITAS E AS SUBVENÇÕES.}

É de se notar que a fiscalização financeira das empresas estatais, das renúncias de receitas e das subvenções revela algumas peculiaridades, ainda mais quando o aspecto sindicado - a legitimidade - possibilita um controle mais profundo e substancial.

Em outras palavras, o controle da legitimidade no particular das empresas estatais, das renúncias de receitas e das subvenções, suscita algumas reflexões específicas que vão além das já aludidas até o presente momento, fazendo-se, portanto, necessária uma análise mais cuidadosa sobre os temas apontados.

5.1 O controle de legitimidade e as empresas estatais.

Há, por certo, alguma confusão conceitual acerca das empresas estatais, logo, é preciso esclarecer, antes de tudo, que estas dizem respeito não só às sociedades de economia mista, como também às chamadas empresas públicas. Ou seja, “empresas estatais" é o gênero do qual são espécies as sociedades de economia mista, de capital misto, e as empresas públicas, cujo capital é inteiramente estatal. Como é sabido, ambas as espécies têm natureza jurídica de direito privado, pertencem ao âmbito da administração indireta e constituem-se como instrumentos estatais para a intervenção na economia e para a prestação de serviços públicos. ${ }^{381}$

${ }^{381}$ DI PIETRO, Maria Sylvia Zanella. Direito...p. 442. 
Por força constitucional, as empresas estatais não escapam à fiscalização financeira arquitetada pelos arts. 70, e seguintes, visto que elas compõem a chamada administração indireta. Recorde-se, destarte, a redação do caput do art. 70 segundo a qual a fiscalização orçamentária, financeira, patrimonial e operacional recai tanto sobre a administração direta como a indireta. De igual forma acontece com a competência dos Tribunais de Contas, que está habilitado, nos termos do art. 71, II, a julgar os administradores e responsáveis por bens e valores públicos pertencentes à administração direta e indireta. ${ }^{382}$

Nota-se, portanto, que as empresas estatais, enquanto tomam parte da administração indireta, estão claramente sujeitas ao controle financeiro apregoado pela Constituição. Todavia, esta não foi a interpretação inicial que o STF deu aos dispositivos constitucionais citados. Ao julgar os Mandados de Segurança nº 23627 e n ${ }^{\circ} 23875$, a Corte Suprema conferiu imunidade às sociedades de economia mista em relação ao controle exercido pelo Tribunal de Contas da União. ${ }^{383}$ Pesou nesses casos a argumentação de que a natureza jurídica das sociedades de economia mista é privada e que elas administram, outrossim, bens privados, dispensando a atuação das Cortes de Contas. Mas se invocou, sobretudo, que a autonomia gerencial de empresas estatais poderia ser diminuída caso fosse admitida a fiscalização pelos Tribunais de Contas.

Ocorre que às empresas estatais deve ser garantida a autonomia operacional, sob pena de desfigurarem-se as razões que motivaram a criação dessas entidades. Há um fundamento para que Administração opere a descentralização e crie pessoas jurídicas autônomas, revestindo-as com o figurino de entes privatísticos. Ao criar uma empresa estatal, a Administração renuncia a certos privilégios e sujeições próprios do regime jurídico de direito público para obter uma liberdade maior em relação à gestão empresarial. Como apregoa Henrique Motta Pinto:

"É preciso valorar a vontade estatal contida no ato de criação da nova pessoa jurídica, e não menosprezá-la como fator de segunda importância. As empresas estatais surgem

\footnotetext{
${ }^{382} \mathrm{O}$ controle financeiro das empresas paraestatais é um reclame antigo da doutrina. Muito antes da CF de 1988 já havia quem defendesse a necessidade e a possibilidade de se sindicar as empresas estatais. Cf. GONÇAVES, Wilson. A Fiscalização financeira das entidades da administração indireta na constituição federal. Revista de Informação Legislativa. Brasília, v. 10, n.39, p. 43-50, jul/set, 1973.

383 BRASIL. Supremo Tribunal Federal. MS 23875/DF e MS 23627/DF. Rel. Min. Carlos Velloso. j. 07.03.2002.
} 
num processo de descentralização que lhes concede autonomia para o cumprimento de uma missão social, e nascem sujeitas a um regime jurídico empresarial, comum a quaisquer empresas, do setor privado ou estatal. Para esta constatação, é indiferente atentar para a sua atuação; uma empresa pode servir a diversos fins, mas é a lógica empresarial que guia o seu cotidiano e as suas relações jurídicas com acionistas, sócios, fornecedores, consumidores, empregados e orienta a sua postura perante a comunidade em que atua", 384

Não se está a advogar, evidentemente, a absoluta igualdade entre as empresas privadas comuns e as empresas estatais. É certo que sobre essas últimas há alguma derrogação de normas de direito privado por normas de direito público, uma vez que são dirigidas pelo ente estatal que as criou e seu escopo precípuo não é o lucro, mas atender finalidades ditadas pelo interesse geral. ${ }^{385}$ Contudo, a natureza de direito privado das empresas estatais não pode ser totalmente derrogada, pois graças a essa feição privatística, elas conseguem uma autonomia operacional mais condizente com o eficaz atendimento de certas necessidades reclamadas pelo interesse público. Depreende-se, nessa esteira, do magistério de Hely Lopes Meirelles ${ }^{386}$, que a natureza privada das empresas estatais não lhes retira a incidência de princípios básicos da Administração, mas lhes asseguram melhores condições de eficiência no desempenho de atividades de natureza econômica.

Assim, ao criar uma empresa estatal, o Estado avalia que este é o melhor método para atingir certas finalidades que reclama o interesse público. A aderência das empresas estatais ao regime jurídico de direito privado é o elemento condutor da vontade estatal ao criá-las, uma vez que, não incidindo integralmente sobre elas o rigor burocrático das normas publicísticas, acabam por gozar de uma liberdade e eficiência muito próximas à autonomia experimentada pelas empresas privadas comuns.

\footnotetext{
${ }^{384}$ MOTTA PINTO, Henrique. A autarquização das empresas estatais na jurisprudência do Supremo Tribunal Federal: um obstáculo para as reformas na administração pública. Caderno de Gestão pública e Cidadania. São Paulo, v. 15, n 57. 2010, p. 227.

${ }^{385}$ Cf. BANDEIRA DE MELLO, Celso Antônio. Curso... p. 180 a 189.

${ }^{386}$ MEIRELLES, Hely Lopes. Direito... p. 364.
} 
Desse modo, o controle financeiro que se exerce sobre as empresas estatais não pode tolher a autonomia e a liberdade gerencial dessas entidades, sob pena de torná-las instrumentos inócuos para lograr êxito nas finalidades que o Estado pretende alcançar ao constituí-las.

Porém, toda essa argumentação que subsidiou, em alguma medida, a posição inicial do STF, não foi suficiente para impedir que a Corte Constitucional alterasse seu entendimento acerca da matéria, permitindo, posteriormente, que a sindicância do Tribunal de Conta alcançasse as empresa estatais.

Nos Mandados de Segurança $n^{\circ} 25181$ e $n^{\circ} 25092$ prevaleceu, por unanimidade, a tese de que as empresas estatais submetem-se, sim, à fiscalização pelos Tribunais de Contas ante os argumentos de que a sindicância das estatais decorre diretamente de preceitos constitucionais que franqueiam o controle externo sobre os entes da administração indireta, bem como que os bens das estatais são públicos, sendo a natureza privada dessas empresas incapaz de obstar a atuação da Corte de Contas. ${ }^{387}$

$\mathrm{Na}$ posição firmada pelo STF, os Ministros não distinguiram entre sociedades de economia mista e empresas públicas, pois entenderam que ambas fazem parte da Administração Indireta e se compõem de bens de natureza pública, razão pela qual se submetem à fiscalização dos Tribunais de Contas.

Mas não se pode deixar de notar, todavia, a preocupação dos Ministros em preservar a autonomia gerencial das empresas estatais. Ainda que reconheçam a competência da Corte de Contas para sindicar as estatais, eles asseveraram que essa sindicância não tem o condão de subtrair as escolhas gerenciais de empresas que atuam sob o influxo das regras do mercado. Ressaltou o Ministro Sepúlveda: "Também deixo explícito outra fonte de preocupações, que há de ter pesado nos precedentes: a de que essa fiscalização se pode tornar abusiva, na medida em que fuja aos estritos limites que constitucionalmente a legitimam e pretenda imiscuir-se na tomada de decisões ou na execução de decisões empresariais das empresas públicas e sociedades de economia mista."

De fato, reputa-se acertado o novo entendimento da Corte Constitucional. A CF de 1988 é de clareza solar ao permitir o controle externo financeiro sobre as entidades da administração indireta, incluindo-se, nessa espécie, as empresas estatais. De outro modo

${ }^{387}$ Cf. BRASIL. Supremo Tribunal Federal. MS 25181/DF. Rel. Min. Marco Aurélio. j. 10.11.2005, e BRASIL. Supremo Tribunal Federal. MS 25092/DF. Rel. Min. Carlos Velloso. j. 10.11.2005. 
não poderia ser, pois o capital dessas empresas é integralizado - na sua totalidade, ou, quando menos na sua maioria - por recursos públicos, bem como a Administração cria tais entidades para atender necessidades públicas. Em outras palavras, as empresas estatais, embora possuam natureza de direito privado, não são entidades desprendidas do interesse da Administração, antes, esta lhes constitui o patrimônio e lhes adjudica finalidades de transcendência coletiva, o que reclama, por si só, o controle financeiro por parte dos órgãos responsáveis.

Nesse diapasão, como advoga Celso Antonio Bandeira de Mello ${ }^{388}$, a própria Lei Maior mitiga, em grande medida, a natureza privada das empresas estatais, colocando-as sob a égide de normas de direito público, como é o caso dos preceitos constitucionais que autorizam a fiscalização pelo Tribunal de Contas sobre elas. Por meio dessa competência, o Tribunal de Contas poderá não só zelar pelo patrimônio, mas também pelas finalidades do interesse público a que estão adstritas as empresas estatais.

Mas o novo posicionamento do STF é, outrossim, acertado sobretudo porque alguns julgadores consignaram, expressamente, as limitações da atribuição sindicante do Tribunal de Contas sobre as empresas estatais. Na sua missão de controle, a Corte de Contas não poderá minar a autonomia gerencial das estatais, logo, o problema que se coloca não é sobre a possibilidade de se exercer a fiscalização financeira externa, mas sim a intensidade do controle a ser efetivado pelo Tribunal de Contas. O Ministro Cezar Peluso aludiu a essa celeuma nos Mandados de Segurança $n^{\circ} 25181$ e no 25092 , assentando que:

"A questão que me pareceu algo mais complexa, mas apenas na aparência, é a da natureza do controle adequado a sociedade ou sociedades que atuam segundo as regras do mercado e da concorrência. Mas, ai, parece-me que o problema é de metodologia da fiscalização, não problema de competência para fiscalizar, isto é, deve o Tribunal de Contas, e de certo o fará por competência técnica, seriedade e bom senso dos seus agentes, conciliar as exigência da autonomia empresarial e do interesse público, até porque, no caso das sociedades de economia mista e das empresas

${ }^{388}$ BANDEIRA DE MELLO, Celso Antônio. Curso... p. 183, 187 e 188. 
públicas, tais requisitos são complementares, não antagônicos"

A Constituição não deixa dúvidas sobre a autorização às Cortes de Contas para fiscalizar as empresas estatais, entretanto, tarefa das mais complexas é compatibilizar essa fiscalização com a preservação da autonomia gerencial das empresas, ainda mais quando se argumenta que o Tribunal de Contas pode aferir a legitimidade dos atos de gestão financeira. Sem qualquer laivo de incerteza, a aferição da legitimidade - e, também, da economicidade - acentuam a profundidade da sindicância, permitindo aos Tribunais de Contas realizar um verdadeiro contraste sobre gestão financeira das estatais o que importa, muitas vezes, em contraditar escolhas e decisões dos responsáveis pela direção operacional da atividade empresarial.

Em todo caso, a competência da Corte de Contas há de observar determinados limites. O Tribunal de Contas não pode colocar-se como o tutor da administração de empresas estatais, sobretudo daquelas que atuam sob o regime de intensa concorrência. Deve haver, por certo, a preservação de aspectos negociais cuja condução depende, exclusivamente, das regras de mercado e da livre concorrência, vedando-se aos Tribunais de Contas o contraste das atividades tipicamente mercantis para as quais as empresas públicas foram criadas.

Demóstenes Tres de Albuquerque ${ }^{389}$ afirma, por sua vez, que o Tribunal de Contas da União não se faz alheio à necessidade de garantir a liberdade gerencial das empresas estatais e cita, como exemplo, a consagrada jurisprudência da Corte de Contas que garante à Petrobrás a dispensa de realizar licitação para atividades inseridas no complexo comercial de exploração, refinamento e venda de combustíveis. O autor elabora uma interessante exegese no sentido de que a atividade fim das empresas estatais merece um tratamento diferenciado por parte dos órgãos de controle com o escopo de lhes preservar a autonomia de mercado e a competitividade econômica. De outra sorte, o autor aduz que as empresas estatais realizam atividades rotineiras, internas e não diretamente relacionadas com a atividade fim, sendo imperioso, nesses casos, que o parâmetro de controle seja menos flexível de modo assemelhar-se com a fiscalização que recai sobre a administração direta.

389 ALBUQUERQUE, Demóstenes Tres. O Tribunal de Contas e o controle das estatais que exploram atividade econômica. In: PEREIRA, Cláudia Fernanda de Oliveira (org.). Controle Externo: temas polêmicos na visão do Ministério Público de Contas. Belo Horizonte: Editora Fórum, 2008. p. 309. 
Logo, se as empresas estatais realizam atividades rotineiras que não compactuam diretamente com a atuação no mercado, estas sofrem o impulso de um controle mais pujante por parte da Corte de Contas, pois nesse particular não que há que cotejar a atuação sindicante com a preservação da autonomia das empresas estatais para bem conduzir sua atividade econômica principal. Cite-se, exemplificativamente, a fiscalização do TCU sobre os contratos de publicidade firmados pela Petrobrás Distribuidora. ${ }^{390}$ Ninguém nega a importância da publicidade para empresas que atuam no regime de mercado, todavia, as empresas estatais devem observar algumas restrições quando da contratação desses serviços, uma vez que o âmbito publicitário não guarda qualquer relação direta com a atividade fim da empresa estatal em comento. O TCU reconheceu, nesse caso, não obstante a natureza jurídica privada da estatal em tela, que a contratação de serviços de publicidade deve observar à Lei 8666 de 1993, que é lei geral de licitações para o Poder Público, bem como indagou sobre a conveniência e o real benefício de patrocínios concedidos a clubes esportivos.

Não se pode deixar de notar que, no caso exposto, sobressai a aferição de legitimidade pelo Tribunal de Contas. Em principio, não é incorreto que Petrobrás Distribuidora se valha de expedientes publicitários, todavia, não é legítimo que o subjetivismo do gestor escolha a empresa responsável pela prestação desses serviços. Uma axiologia baseada na impessoalidade e na preservação do patrimônio público impõe à estatal a necessidade de realizar licitação para a contratação de serviços publicitários, pois o certame, além de selecionar a melhor proposta, não faz prevalecer a preferência do gestor para contratar um empresa em detrimento das demais. Assim, ainda que a autonomia privada das estatais lhe defira uma maior liberdade de atuação mercadológica, é preciso afirmar que a contratação de serviços publicitários só é legítima quando precedida de licitação. Até mesmo os patrocínios concedidos pela Petrobrás aos clubes esportivos deve passar por um juízo de legitimidade. Não lhe cabe dispensar patrocínios arbitrariamente, antes, a legitimidade desses auxílios comprova-se quando eles revertem em algum benefício à atividade precípua da empresa de modo que a autonomia do gestor fica restrita à comprovação do real proveito econômico obtido com a promoção de grêmios esportivos.

Ressalte-se, por outro lado, que no exemplo citado não se pode cogitar de interferências do TCU quanto à autonomia negocial da atividade fim da empresa, que é a distribuição de combustível. O Tribunal de Contas não contrastou estratégias mercantis

${ }^{390}$ BRASIL. Tribunal de Contas da União TC 008.450/2002-7. Rel. Min. Adylson Motta. j. 30.07.2003. 
próprias à finalidade precípua da empresa estatal, mas revisou, sim, atos e contratos que não se relacionam com a atividade essencial da empresa e que podem acarretar prejuízos ao patrimônio da estatal.

Desse modo, as atividades-meios das empresas estatais estão, a toda evidência, sujeitas ao vigoroso controle exercido pela Corte de Contas. Os administradores das estatais não podem valer-se da estrutura empresarial privada para perpetrarem, mais facilmente, todo o gênero de desvios. Antes, a atuação irregular dos gestores deve encontrar barreiras na função de controle do Tribunal de Contas.

A liberdade gerencial que se concede às empresas estatais é com vistas a promover a compatibilidade destas com os mecanismos de mercado, garantindo que a atividade fim da empresa possa desenvolver-se sem maiores dificuldades em um ambiente econômico marcado pela livre iniciativa e ampla concorrência. Portanto, somente no que tange à atividade fim da empresa estatal é que o Tribunal de Contas deve se abster de exercer uma fiscalização mais intensa, procurando respeitar as decisões e estratégias mercantis que guiam a atividade negocial da empresa estatal.

Reafirme-se, assim, que as empresas estatais não escapam ao controle dos Tribunais de Contas; seus administradores, inclusive, podem ser julgados por esta Corte na medida em provoquem qualquer dano ao patrimônio público. No entanto, essa função sindicante encontra alguns balizamentos, pois a Corte de Contas não poderá imiscuir-se em decisões tipicamente empresariais que nortearam a atividade principal para a qual a empresa estatal foi criada. Em outros termos, os atos relacionados com a atividade fim das empresas estatais estão preservados de uma atuação mais robusta dos Tribunais de Contas, garantindo às estatais a liberdade necessária para atender com eficiência a finalidade pública por elas perseguida.

\subsection{O controle de legitimidade e as renúncias de receitas.}

Averiguar a legitimidade das renúncias de receitas comporta em verificar a procedência de seu real benefício sócio-econômico e se tais benesses foram concedidas segundo princípios e valores que denotam o sentido de justiça. 
Note que as receitas arrecadadas pelo Estado destinam-se ao financiamento das necessidades públicas e, por certo, renunciar a tais receitas resulta em um sensível gravame ao interesse fiscal do Estado. Estevão Horvath recorda que o Estado arrecada recursos para atuar em benefício de toda a coletividade, logo, a renúncia de receitas só encontra justificativa quando amparada na axiologia albergada pelo Texto Maior. Em relação à renúncia de receitas tributárias assevera o autor: "Noutro giro, a renúncia à arrecadação de tributos também deve encontrar fundamento constitucional para poder existir. Não se cuida de atuação meramente discricionária, colocada ao bel-prazer de quem renuncia. Há de existir justificativa embasada nos princípios e valores constitucionais que implique o acolhimento de tal abandono."391

Diante dos mais variados reclames sociais e individuais que o Estado deve atender, ele não pode, simplesmente, abdicar dos recursos a que tem direito de perceber. Eis que as necessidades públicas devem encontrar o respectivo respaldo financeiro, sem o qual será impossível satisfazer, a contento, os misteres estatais. Nesse contexto, toda renúncia de receitas deve ter um justificativa plausível e que encontre fundamento em critérios de justiça agasalhados pelo texto constitucional. Não pode o alvedrio subjetivo conduzir a concessão de favores e benesses fiscais, pois qualquer renúncia de receitas tem de ter um efeito prático sensivelmente melhor do que teria a efetiva arrecadação.

Faça-se eco, aqui, às críticas de Ricardo Lobo Torres ${ }^{392}$, para quem os privilégios tributários e financeiros pela vertente das receitas públicas serviram durante décadas para ocultar benefícios odiosos a setores improdutivos da economia. Ele relata que isenções e subsídios eram concedidos de forma indiscriminada e muito pouco transparente para setores econômicos que, seguramente, não mereceriam nenhum incentivo. Desse modo, as renúncias de receitas não podem prestar-se à concretização de privilégios ilegítimos. Antes, devem promover a justiça fiscal, procurando, exemplificativamente, nos termos da Constituição, equilibrar as desigualdades regionais, prestigiar a capacidade contributiva e fomentar o desenvolvimento econômico.

No campo da legislação infraconstitucional há, também, uma preocupação em limitar as renúncias de receitas. Especificamente, a Lei de Responsabilidade Fiscal empenhou-se em balizar a concessão de benefícios fiscais apregoando em seu artigo $1^{\circ}$ que a gestão fiscal responsável pressupõe a observância de limites e condições no que tange à

${ }^{391}$ HORVATH, Estevão. O Direito Tributário no contexto da atividade financeira do Estado. São Paulo: edição do autor, 2009. p. 120.

392 TORRES, Ricardo Lobo. Tratado... p. 319 a 325. 
renúncia de receitas. Coube ao art. 14, I e II, da LRF consignar as limitações para a concessão de renúncias de receitas, a saber: a concessão de incentivos e benesses na vertente das receitas públicas deve estar acompanhada da estimativa de impacto orçamentário, na qual se demonstrará que a renúncia foi previamente planejada, não afetando os resultados e metas fiscais, ou que os incentivos serão compensados por meio do aumento na arrecadação.

A renúncia de receitas não pode, portanto, frustrar as metas de arrecadação e o êxito dos resultados fiscais e, caso a renúncia seja implementada, a despeito das metas e resultados fiscais, exige-se a adoção de medidas compensatórias que garantam a higidez fiscal das contas públicas. Percebe-se, então, que a ratio legis é impedir a renúncia indiscriminada de receitas públicas, preservando-se o equilíbrio fiscal e a capacidade de financiamento do Estado para bem prover as necessidades individuais e coletivas dos cidadãos.

Ainda, a LRF não se furtou em definir os mecanismos pelos quais se opera a renúncia de receitas, registrando-os no $\S 1^{\circ}$ do art. 14 , que prescreve: "A renúncia compreende anistia, remissão, subsídio, crédito presumido, concessão de isenção em caráter não geral, alteração de alíquota ou modificação de base de cálculo que implique redução discriminada de tributos ou contribuições, e outros benefícios que correspondam a tratamento diferenciado."

Verifica-se da leitura do preceito citado que os institutos afeitos às renúncias de receitas possuem uma evidente natureza tributária. ${ }^{393}$ Com efeito, é importante ressaltar que esses mecanismos tributários pelos quais se opera a renúncia de receitas submetem-se a uma sistemática constitucional específica. Por exigência da legalidade em matéria tributária, todos esses mecanismos que concedem benefícios fiscais deverão ser veiculados mediante lei. Assim, dispõe o $§ 6^{\circ}$ do art. 150 da CF de 1988:

“Qualquer subsídio ou isenção, redução de base de cálculo, concessão de crédito presumido, anistia ou remissão, relativos a impostos, taxas ou contribuições, só poderá ser concedido mediante lei específica, federal, estadual ou

\footnotetext{
${ }^{393}$ Excetua-se, é claro, do subsídio que se inclui no conceito de subvenção, consubstanciado-se em uma benesse financeira pelo prisma da despesa pública. Cf. HERIQUES, Elcio Fiori. Os benefícios ... p. 35 e 140 a 147.
} 
municipal, que regule exclusivamente as matérias acima enumeradas ou o correspondente tributo ou contribuição, sem prejuízo do disposto no art. $155, \S 2 .{ }^{\circ}$, XII, g. "

Não obstante a legalidade seja a regra para conceder os benefícios fiscais, é de se reconhecer, todavia, as exceções que a própria Constituição veicula ao autorizar a alteração, por via administrativa, das alíquotas dos tributos de natureza extrafiscal. ${ }^{394}$ Destarte, pode se dizer que certos privilégios fiscais, que dependem da alteração da alíquota, podem ser concedidos por ato do Poder Executivo, prescindo de lei formal ordinária.

Em todo caso, as particularidades das normas constitucionais permitem concluir que os institutos tributários que geram renúncia de receitas só podem ser veiculados por meio de lei ou por ato do Executivo que, autorizado constitucionalmente, poderá reduzir as alíquotas dos tributos de acento extrafiscal.

Tudo isso evidencia a existência de um plexo de discricionariedade política acerca da decisão que concede os benefícios fiscais. Em última análise, o Parlamento e o Poder Executivo decidem, com alguma liberdade, sobre a outorga de privilégios fiscais, renunciando às receitas que poderiam ingressar nos cofres públicos. Sendo assim, é de se questionar se o Tribunal de Contas, a título do controle de legitimidade das renúncias de receitas, poderia enfrentar o mérito de uma lei ou de um ato do Poder Executivo que defere o benefício fiscal. Em outros termos, interroga-se sobre a competência dos Tribunais de Contas para censurar uma lei ou um ato do Poder Executivo que implique em concessão de benefício fiscal.

A resposta é, certamente, negativa. A legitimidade dos benefícios fiscais não está sob o juízo do Tribunal de Contas. A renúncia de receitas tributárias possui um aspecto político notório, pois sua concessão fica a depender de critérios de conveniência e oportunidade que indicam os meios mais acertados para a realização da justiça tributária e do fomento econômico. E, na medida em que se exige a lei ou o ato do Poder Executivo para veicular os benefícios fiscais, cabem somente ao Executivo e ao Legislativo a decisão sobre como, quando, em que e de quanto será a renúncia de receitas tributárias.

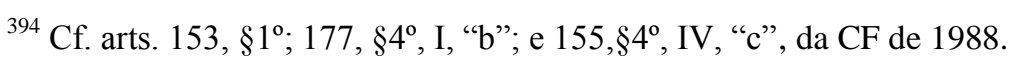


Desse modo, caso o Tribunal de Contas pudesse julgar a legitimidade de benefícios fiscais ele estaria se imiscuindo em competências, que, seguramente, não lhe pertencem. Não lhe cabe decidir sobre meios mais adequados à realização da justiça fiscal e do fomento econômico. Essas atribuições recaem, sobretudo, aos órgãos de representação política, ou seja, o Executivo e o Legislativo que, em última análise, são os responsáveis pela definição dos fins e dos meios inerentes à consecução do bem comum.

Muito menos competiria ao Tribunal de Contas embaraçar prerrogativas constitucionais do Chefe do Executivo para manejar as alíquotas de tributos extrafiscais. Essa faculdade é um instrumento imprescindível para a regulação da economia e a indução de comportamentos benéficos à coletividade de modo que a Corte de Contas resta, também, impedida de contraditar as escolhas do Poder Executivo acerca da alteração das alíquotas dos tributos de natureza extrafiscal.

Desse modo, um julgamento definitivo sobre a legitimidade das renúncias de receitas tributárias só poderia ser dado, genericamente, pelo Parlamento, quando da apreciação global das contas do Chefe do Executivo. Não cabe, portanto, ao Tribunal de Contas julgar a legitimidade das renúncias de receitas que se operam pela via dos benefícios fiscais. Helio Mileski reconhece que, nos casos relativos à disciplina legal da LRF, a competência do Tribunal de Contas limita-se à fiscalização de acompanhamento e a emissão do parecer prévio sobre as contas, sem, contudo, proferir uma decisão peremptória sobre a gestão fiscal. Assevera Mileski:

“conforme está posto na Lei Complementar 101/2000, o exercício da fiscalização pelo Tribunal de Contas $e$ a emissão do parecer prévio conclusivo não ensejam uma decisão propriamente dita, na medida em que se trata de uma lei de acompanhamento, em que o órgão de fiscalização acompanha a ação administrativa quanto à prática de atos de gestão fiscal, verificando o alcance das metas fixadas pela Administração Pública e dizendo de sua conformidade ou não com determinações legais, contudo, sem proceder ao 
julgamento dos atos de gestão fiscal e, consequentemente, sem aplicar sanções em decorrência do exame realizado." 395

O que Mileski leciona é que a eventual inobservância das normas apregoadas pela LRF não franqueiam a possibilidade de um julgamento peremptório por parte da Corte de Contas, a qual apenas verificará o atendimento de metas, resultados e diretivas fiscais, sem, contudo, sancionar o agente que descumpre as regras relativas à gestão fiscal responsável. Conforme esclarece Emerson Cesar Gomes ${ }^{396}$, a LRF não estabeleceu sanções pessoais aos agentes públicos, mas, tão somente, penalidades aos entes federados. Coube à Lei 10.028 estabelecer as infrações administrativas e os crimes e relativos às faltas pessoais cometidas em desprestígio às regras de responsabilidade fiscal.

Todavia, as infrações administrativas da Lei 10.028 de 2000, a serem apuradas pelo Tribunal de Contas, não evidenciam uma preocupação direta com descumprimento de metas e resultados fiscais. A inobservância das condições e dos limites impostos para a concessão de renúncia de receitas, por exemplo, não figura como causa de sanção administrativa a ser aplicada pela Corte de Contas. ${ }^{397}$

Nesses termos, a fiscalização que os Tribunais de Contas exercem sobre os limites e as condições impostas para a renúncia de receitas na LRF é de mero acompanhamento, abstendo-se de censurar, definitivamente, a inobservância da disciplina consignada para a concessão de benefícios fiscais. Logo, se o Tribunal de Contas não julga propriamente aqueles que não observaram os limites e as condições para as renúncias de receitas, com maior razão esta Corte não poderá apreciar a legitimidade dos benefícios fiscais concedidos.

\footnotetext{
${ }^{395}$ MILESKI, Hélio Saul. O Controle... p. 279.

${ }^{396}$ GOMES, Emerson Cesar da Silva. Responsabilidade Financeira: uma teoria sobre a responsabilidade no âmbito dos tribunais de contas. Porto Alegres:Nuria Fabris, 2012. p. 184.

${ }^{397}$ Conforme o art. $5^{\circ}$ da lei 10.028: "Constitui infração administrativa contra as leis de finanças públicas: I - deixar de divulgar ou de enviar ao Poder Legislativo e ao Tribunal de Contas o relatório de gestão fiscal, nos prazos e condições estabelecidos em lei; II - propor lei de diretrizes orçamentárias anual que não contenha as metas fiscais na forma da lei; III - deixar de expedir ato determinando limitação de empenho e movimentação financeira, nos casos e condições estabelecidos em lei; IV - deixar de ordenar ou de promover, na forma e nos prazos da lei, a execução de medida para a redução do montante da despesa total com pessoal que houver excedido a repartição por Poder do limite máximo. $\$ 1^{\circ}$ A infração prevista neste artigo é punida com multa de trinta por cento dos vencimentos anuais do agente que lhe der causa, sendo o pagamento da multa de sua responsabilidade pessoal. $\S 2^{\underline{o}} \mathrm{~A}$ infração a que se refere este artigo será processada e julgada pelo Tribunal de Contas a que competir a fiscalização contábil, financeira e orçamentária da pessoa jurídica de direito público envolvida."
} 
Reafirme-se, assim, que o mérito dos benefícios fiscais concedidos por lei ou por prerrogativa constitucional do Poder Executivo não está sob o juízo do Tribunal de Contas. A fiscalização financeira quanto à legitimidade das renúncias de receitas não pode, pelas razões expostas, permitir que o Tribunal de Contas devasse critérios políticos que orientaram a concessão de benefícios fiscais. Não obstante, deve-se afirmar que os Tribunais de Contas estão constitucionalmente habilitados para julgar a legitimidade dos atos de renúncia da arrecadação de receitas certas e exigíveis. Não se trata aqui de controlar o mérito dos benefícios fiscais concedidos mediante lei ou por prerrogativa constitucional do Chefe do Executivo, mas sim de fiscalizar eventuais falhas na arrecadação das receitas públicas perfeitamente líquidas, certas e exigíveis. Nesse particular, é a própria atividade arrecadatória da Administração em buscar as receitas devidas que pode ser apreciada e julgada pelo Tribunal de Contas.

Quando se advoga que o Tribunal de Contas pode julgar as renúncias de receitas é evidente que não se coloca sobre a sua competência julgadora o mérito de uma lei ou ato de um Executivo que defere benefícios fiscais pela vertente da receita pública. $\mathrm{O}$ que o Tribunal de Contas pode julgar, com base no art. 71, II da CF, é o dano patrimonial provocado pela renúncia de receitas que deveriam ser arrecadas e não foram. Note, nesse sentido, que a lógica dos benefícios fiscais é muito diferente, pois, nesses casos, as receitas renunciadas poderiam ser arrecadadas e não foram porque a lei ou a prerrogativa constitucional do Executivo dispensou o recolhimento.

O juízo do Tribunal de Contas sobre a renúncia de receitas pode ser exercido, então, quando não há nenhum expediente, legal ou constitucional, dispensando o recolhimento. Ou seja, nos casos em que o Tribunal de Contas julga as renúncias de receitas, nenhum comando legal ou constitucional escusa o recolhimento de valores; simplesmente, as receitas certas e exigíveis não ingressam nos cofres públicos porque a conduta do agente administrativo é ilícita, ímproba, grosseira e negligente, provocando um claro dano ao erário público. Nada obsta, por exemplo, que a Corte de Contas julgue e sancione o agente moroso que dá causa à prescrição de créditos devidos à Fazenda Pública.

Em relação à fiscalização quanto à legitimidade na renúncia de receitas certas e exigíveis destaca-se um julgamento da Corte de Contas de São Paulo. Esse Tribunal julgou regulares as contas de empresa municipal de saneamento muito embora tenha constatado que a entidade deixará prescrever um volume considerável de créditos. $\mathrm{Na}$ assentada, pesou a questão da legitimidade na renúncia da arrecadação, uma vez que as 
dívidas prescritas referiam-se aos débitos de escolas da rede municipal e de instituições de reconhecida benemerência. 398

No caso, não havia norma autorizando a dispensa do pagamento. Os créditos eram certos e exigíveis e a empresa estatal deveria buscar essa receita. No entanto, a notória função de interesse público exercida por alguns devedores fez com que a empresa municipal renunciasse à cobrança de débitos das instituições municipais de ensino e das agremiações beneméritas. O Tribunal de Contas, por sua vez, entendeu legítima essa renúncia de receitas, pois vislumbrou que a conduta não era imoral, mas justificada ante a axiologia encampada pelo texto constitucional. Eis que as escolas públicas e as entidades de benemerência prestam serviços de notório interesse público, merecendo, legitimamente, gozar de certos incentivos financeiros que podem afetar a arrecadação de receitas públicas.

Fica claro no exemplo colacionado a pouco que o Tribunal de Contas pode julgar a legitimidade das renúncias de receitas certas e exigíveis, verificando eventual dano ao patrimônio público e o real benefício socioeconômico obtido com tais renúncias. Efetivamente, se o agente estatal abandona recursos que deveria buscar, essa inércia só é legítima se tiver uma finalidade consentânea com o bem comum. A Administração não pode renunciar a receitas certas e exigíveis sem um fundamento razoável que denote, por exemplo, a preocupação com a justiça social, com a erradicação da pobreza e das desigualdades, balizando-se, ao mesmo tempo, a imperiosa necessidade de financiamento dos cofres públicos.

Logo, se as renúncias de receitas certas e exigíveis evidenciam um indiscutível gravame ao patrimônio público, é verdade, também, que em alguns casos elas podem se afigurar legítimas, pois são dispensadas em prestígio a critérios de justiça que permeiam a ordem jurídica. De fato, somente o caso concreto poderá esclarecer a legitimidade de eventual renúncia de receitas, exigindo-se do Tribunal de Contas um juízo de ponderação sobre o efetivo benefício socioeconômico logrado com a renúncia em contraposição com a imperativa necessidade dos ingressos públicos.

Ressalte-se, por fim, que o controle que o Tribunal de Contas exerce sobre as renúncias de receitas deve ser distinguido. De um lado, a Corte de Contas pode julgar qualquer altruísmo com o abandono de receitas certas e exigíveis, verificando eventuais impropriedades quando da abdicação de ingressos que deveriam adentrar aos cofres

398 Cf. BRASIL. Tribunal de Contas do Estado de São Paulo. TC- 2297/026/09. Rel. Robson Marinho. j. 20.10.2010. 
públicos. De outro lado, não lhe compete julgar a legitimidade dos benefícios fiscais concedidos por lei ou por prerrogativa constitucional do Executivo, pois, se assim o fizesse, a Corte de Contas estaria invadindo a esfera de discricionariedade política própria dos Poderes Legislativo e Executivo. Nesses casos, a atuação do Tribunal de Contas limitase à sindicância de acompanhamento, sem emitir, contudo, um juízo peremptório sobre a procedência ou improcedência dos benefícios fiscais deferidos.

\subsection{O controle de legitimidade e as subvenções.}

Ao tratar do tema das subvenções, Ricardo Lobo Torres ${ }^{399}$ anota, desde logo, que estas só são legítimas desde que afinadas com a idéia de justiça. O autor assinala a correção ética de subvencionar entidades assistenciais e empresas cuja atividade se mostre estratégica para viabilizar o crescimento econômico e desenvolver regiões menos favorecidas. Todavia, diante de focos de miséria absoluta, ele afirma o total despropósito em conceder subvenções a clubes de futebol, sociedades carnavalescas e entidades recreativas.

Com base nas assertivas de Ricardo Lobo Torres não se pode deixar de reconhecer a possibilidade de contrastar a legitimidade na concessão de subvenções. Parece evidente que o emprego de auxílios públicos em atividades que em nada contribuem para o bem comum deve merecer uma rigorosa censura. Entretanto, é preciso investigar a sistemática jurídica que regula o instituto das subvenções no intuito de identificar o órgão responsável pela aferição e julgamento da legitimidade dessas benesses.

Nos termos do art. 12 da Lei 4.320 de 1964, as subvenções figuram na categoria econômica das despesas correntes a serem previstas no orçamento. Precisamente, o $\S 3^{\circ}$, do art. 12, da referida lei conceitua subvenções como as transferências destinadas a cobrir despesas de custeio das entidades beneficiadas. O parágrafo citado se desdobra em dois incisos que distinguem entre subvenções sociais, que se destinam a entidades assistenciais ou culturais sem fins lucrativos, e subvenções econômicas voltadas ao

\footnotetext{
${ }^{399}$ TORRES, Ricardo Lobo. Tratado ... p. 326. "As subvenções, desde que afinadas com a idéia de justiça, são legítimas".
} 
subsídio de empresas, públicas ou privadas, de caráter comercial, industrial, agrícola ou pastoril.

Mas o que importa ressaltar, nesse particular, é que as subvenções não fogem da orçamentação pública, antes, encontram a respectiva previsão na lei orçamentária sob a rubrica de uma categoria econômica precisa. De seu turno, o art. 26 da LRF exige que as subvenções, além de encontrar previsão orçamentária, devem ser autorizadas por lei específica, sendo sua concessão condicionada ao atendimento de requisitos prévios estabelecidos pela lei de diretrizes orçamentárias. ${ }^{400}$

Assim, a previsão e o destino das subvenções estão plasmados tanto na lei orçamentária, como na lei específica que autoriza a sua concessão. A destinação de auxílios financeiros pela via das subvenções fica, então, ao critério do legislador que, por sua vez, define o quantum do auxílio público, bem como indica quem são seus potenciais beneficiários.

Comprovar que as subvenções são definidas por lei, seja ela orçamentária ou específica, é importante para compor o quadro do controle financeiro desses auxílios públicos. É bem verdade que o art. 70, caput, da CF impõe o controle externo e interno sobre as subvenções, todavia, sendo esse auxílio financeiro dispensado por lei, é de se indagar a competência do Tribunal de Contas para apreciar e julgar a legitimidade da previsão legal das subvenções. Em outras palavras, questiona-se a possibilidade da Corte de Contas verificar a legitimidade da lei, orçamentária e específica, que opera a destinação das subvenções.

Conforme raciocínio já expresso alhures, fica claro que o Tribunal de Contas não está habilitado a contraditar a legitimidade da previsão legal de determinada subvenção. Se assim fosse, a Corte de Contas estaria invadindo os critérios de conveniência política próprios do Legislativo e do Executivo e que orientaram a fixação do dispêndio. Decidir qual entidade receberá o auxílio público, bem como o volume de recursos que haverão de perceber é da competência peculiar do Executivo e do Legislativo, que, por meio de lei, indicarão quais serão as entidades empresariais e beneméritas contempladas pelas subvenções.

\footnotetext{
${ }^{400}$ Art. 26 da LRF: “A destinação de recursos para, direta ou indiretamente, cobrir necessidades de pessoas físicas ou déficits de pessoas jurídicas deverá ser autorizada por lei específica, atender às condições estabelecidas na lei de diretrizes orçamentárias e estar prevista no orçamento ou em seus créditos adicionais." Outrossim, cf. CONTI, José Mauricio (coord). Orçamentos Públicos: a lei 4320 de 1964 comentada. São Paulo: RT, 2008. p. 80.
} 
Vale lembrar que a fixação da despesa no orçamento tem viés nitidamente político e, portanto, reserva-se à previsão legal das despesas públicas um julgamento de índole igualmente política a ser perpetrado pelo Legislativo. Quando muito o Tribunal de Contas pode consignar suas opiniões no parecer prévio, mas deve se abster de realizar qualquer julgamento acerca da previsão legal das despesas públicas. Do mesmo modo ocorre com a previsão legal e orçamentária das subvenções, eis que a fixação normativa desses auxílios financeiros depende do exercício da discricionariedade política do Executivo e do Legislativo, vedando-se à Corte de Contas o contraste da decisão que opera a determinação legislativa das subvenções.

Mas essa limitação não diminui a importância dos Tribunais de Contas quanto à fiscalização das subvenções, pois é preciso ressaltar que o controle das Cortes de Contas alcança diretamente a atuação das entidades beneficiadas com a subvenção. $\mathrm{O}$ $\mathrm{STF}^{401}$ em jurisprudência antiga já franqueava ao Tribunal de Contas a possibilidade de sindicar entidades privadas que recebiam recursos públicos. A ementa do MS 21644/DF afirma, explicitamente, que:

"Embora a entidade seja de direito privado, sujeita-se à fiscalização do Estado, pois recebe recursos de origem estatal, e seus dirigentes hão de prestar contas dos valores recebidos; quem gere dinheiro público ou administra bens ou interesses da comunidade deve contas ao órgão competente para a fiscalização. 5. Hipótese de competência do Tribunal de Contas da União para julgar a matéria em causa, a teor do art. 71, II, da Constituição, havendo apuração dos fatos em procedimentos de fiscalização, assegurada ao impetrante ampla defesa."

É, como relata Rodrigo Pagani ${ }^{402}$, indeclinável reconhecer que o Tribunal de Contas está autorizado a fiscalizar as entidades contempladas com a subvenção e julgar, diretamente, os responsáveis por qualquer impropriedade no emprego dos recursos públicos a elas transferidos. Isso porque a Constituição põe a cargo do Tribunal de Contas

\footnotetext{
${ }^{401}$ BRASIL. Supremo Tribunal Federal. MS 21644/DF. Rel. Min. Néri da Silveira. j. 08.11.1996.

402 SOUZA, Rodrigo Pagani. O controle estatal das transferências de recursos públicos para o terceiro setor. Tese de Doutorado. Faculdade de Direito da USP. São Paulo: edição do autor, 2009. p. 174 a 177.
} 
a missão institucional de julgar os administradores e responsáveis por bens e valores públicos, bem como qualquer pessoa que der causa, perda, extravio ou outra irregularidade que resulte em prejuízo ao erário público (art. 71, II, da CF). Evidencia-se, então, que as competências do Tribunal de Contas atingem qualquer um que lide com recursos públicos, inclusive, os gestores de entidades privadas que não compõem os quadros da Administração, mas que recebem e gerenciam bens e valores públicos, notadamente, as subvenções.

Afirme-se, nesse sentido, a possibilidade do Tribunal de Contas investigar a aptidão estrutural das entidades assistenciais para bem prestar serviços de interesse público custeados com as subvenções. Tal como preconiza o parágrafo único do art. 16 e o art. 17, caput, da Lei 4320 de 1964, as entidades contempladas com as subvenções devem demonstrar padrões mínimos de eficiência e condições satisfatórias de funcionamento para lograr perceber as subvenções. Do contrário, deferir subvenções a entidades impossibilitadas de bem prestar serviços assistenciais representaria um grave desperdício de recursos públicos, uma vez que o seu emprego não resultaria em benefícios socioeconômicos efetivos, culminando, apenas, em prejuízo aos cofres públicos.

Se as entidades a quem se concedem as subvenções não possuem condições estruturais de realizar a contento suas atividades, elas não podem receber esses auxílios públicos. Ocorre que a simples destinação legal e orçamentária da subvenção não enseja para a entidade contemplada o direito subjetivo de recebê-la. Régis de Oliveira, fundado em remota jurisprudência da Corte Constitucional, leciona de modo inequívoco que: "Pode-se afirmar, pois, sem sombra de dúvida que não há direito à subvenção. É mera expectativa de direito, a depender, seu exercício, de circunstâncias empíricas e da fiscalização do agente público encarregado não só da liberação do recurso, mas de seu destino". 403

Régis de Oliveira ${ }^{404}$ critica, ainda, certa imprudência do Legislativo e do Executivo em liberar os recursos relativos às subvenções sem, antes, verificar a aptidão das entidades beneficiadas para prestar os serviços de modo satisfatório. Desse modo, nada impede que os Tribunais de Contas analisem a procedência dos repasses das subvenções, verificando a competência estrutural das entidades beneficiadas para bem prestar os serviços a que se propõem. Diga-se, também, que a Corte de Contas pode julgar, inclusive,

${ }^{403}$ OLIVEIRA, Régis Fernandes. Curso... p. 384.
${ }^{404}$ Idem. 
os agentes administrativos que liberaram subvenções às entidades inaptas para escorreita prestação de serviços assistenciais.

$\mathrm{Na}$ verdade, a mera previsão orçamentária não basta para efetivar o repasse das subvenções, pois a transferência dos recursos viabiliza-se por meio de expedientes administrativos como os convênios, contratos de gestão, termos de parceria e outros instrumentos congêneres que são firmados entre a Administração e a entidade beneficiada. ${ }^{405}$ Nesses casos, a celebração de tais acordos com o Poder Público exige que a entidade privada demonstre sua capacidade para gerir adequadamente os recursos repassados, bem como ateste o adimplemento de requisitos estabelecidos em lei e em outros atos normativos que regulamentam a liberação das subvenções. ${ }^{406}$

Logo, se os agentes administrativos não se mostram cuidadosos na análise da capacidade gerencial das entidades beneficiadas, repassando os auxílios públicos a quem não tem competência técnica para bem empregá-los, eles podem sofrer as sanções aplicadas pelas Cortes de Contas, pois se responsabilizam, solidariamente, pela má destinação e aplicação dos recursos públicos. Constatada a deficiência das entidades subvencionadas, o agente administrativo que autorizou o repasse de recursos financeiros, mediante os mais variados acordos, responderá por eventual dano ao erário, pois não vigiou para que o numerário fosse destinado a quem pudesse bem geri-los. ${ }^{407}$

Sublinhe-se que, nesse particular, o Tribunal de Contas não contrasta a conveniência política da previsão legal e orçamentária da subvenção. A Corte apenas julga e sanciona o agente administrativo faltoso que não se assegurou da efetiva capacidade da entidade subvencionada em gerir satisfatoriamente os recursos a ela repassados.

Por outro lado, não se pode deixar de consignar a habilitação do Tribunal de Contas para averiguar a legitimidade na aplicação das subvenções pelos próprios gestores das entidades beneficiárias, julgando-os - nos termos do art. 71, II, da CF - por eventual dano ao patrimônio público. Ocorre, não raras vezes, que as finalidades das subvenções são pervertidas sem, contudo, macular o aspecto de legalidade formal. Nesse sentido, a

\footnotetext{
405 “Os instrumentos jurídicos mais comuns para a concessão de subvenções são os contratos de gestão, celebrados com organizações sociais, e os termos de parceria, com as organizações da sociedade civil de interesse público." CONTI, José Mauricio (coord). Orçamentos... p.80.

${ }^{406}$ Ribamar Caldas Furtado, ao discorrer sobre a fiscalização das subvenções dedica grande atenção à analise das leis e dos atos normativos que regulamentam a concessão de repasses financeiros. Cf. FURTADO, José de Ribamar Caldas. Elementos... p.335 a 342.

${ }^{407}$ Confira, nessa linha, o art. $254, \S 2^{\circ}$, do Regimento Interno do TCU que impõe multa para a autoridade administrativa que transferir, mediante acordo, convênio ou outro instrumento congênere, recursos federais a gestores omissos na prestação de contas ou que tenham dado causa a qualquer perda, extravio ou irregularidade que resulte dano ao erário.
} 
escorreita aplicação das subvenções reclama um exame acentuado de legitimidade cujo objetivo é garantir, sobretudo, a correção ética na gestão dos auxílios públicos.

A título de aferir legitimidade das subvenções, a Corte de Contas poderá realizar uma pujante fiscalização na gestão dos valores públicos repassados, verificando o modo como os recursos estatais foram empregados. Sobressai, assim, a possibilidade de se empreender uma análise não somente voltada a eficiência da gestão, mas também um exame ético da conduta dos administradores privados quanto à aplicação dos recursos públicos. Não é demais ressaltar que todo o espectro decisório dos gestores das entidades subvencionadas pode ser sindicado pelo Tribunal de Contas em face de preceitos valorativos que, se afrontados, reclamam uma atuação contundente. Cite-se, como exemplo, a relevante atuação do TCU ao exigir, no que couber, o procedimento licitatório para entidades privadas beneficiadas com subvenções.

A rigor, a Lei 8666 de 1993, a lei geral de licitações, não se aplica aos entes privados que não compõem os quadros administrativos, todavia, o fato de que elas recebem subvenções públicas foi determinante para que a Corte de Contas da União lhes determinasse a realização de licitação para a aplicação dos recursos públicos recebidos. Confira os termos do voto do relator no $\mathrm{TC}^{\circ}$ 003.361/2002-2:

"É notório que a iniciativa privada não se sujeita aos princípios que regem a licitação no setor público e muito menos está obrigada a aplicar, nas suas contratações, a Lei $n^{\circ} 8.666 / 93$, mesmo porque naquela impera a autonomia da vontade e, por isso mesmo, só não pode fazer o que a lei expressamente proíbe, ao contrário do administrador público que só pode fazer o que a lei determina. No entanto, o particular, ao firmar convênio com a administração pública, assume todos os deveres e obrigações de qualquer gestor público, estando, como este, sujeito aos princípios da legalidade, da impessoalidade, da moralidade e dos demais princípios informadores da gestão da coisa pública, dentre os quais destacamos o da licitação e o do dever de prestar contas, insculpidos no art. 37, inciso XXI, e art. 70, 


parágrafo único, da Constituição
respectivamente." 408

Ainda que não haja, explicitamente, uma lei minudenciando a forma de gestão das subvenções, especialmente quanto à obrigatoriedade de se realizar licitações, é fato que o ente privado não pode aplicar os recursos públicos arbitrariamente. A natureza estatal do numerário repassado exige dos gestores privados uma atuação conforme os princípios reitores da coisa pública, evidenciando a necessidade de aderir a um padrão de legitimidade peculiar. No caso específico da exigência de licitação, os responsáveis pela aplicação das subvenções devem procurar a melhor proposta, buscando de modo impessoal aqueles que serão remunerados com os recursos públicos. Não resultaria consentâneo com a legitimidade aplicar as subvenções prodigamente, muito menos usá-las para privilegiar alguns em detrimento de outros, por isso, o certame licitatório é uma necessidade que se impõe.

Esse exemplo revela que os repasses públicos não podem ser empregados de modo apartado da axiologia que rege a Administração. Ao gerir recursos públicos, os entes privados têm, seguramente, sua autonomia da vontade mitigada por princípios administrativos como o da moralidade, da impessoalidade, da publicidade, entre outros, que, por sua vez, imprimem a necessidade de aderir a padrões de correção mais vigorosos, superando a mera legalidade estrita. Não se cogita, portanto, que a gestão das subvenções fuja à observância de mandatos axiológicos típicos do Poder Público, franqueando-se, nessa linha, aos Tribunais de Contas a possibilidade de constatar qualquer ilegitimidade na aplicação das subvenções, e censurar, se necessário, os agentes privados que cometerem alguma impropriedade com o patrimônio do Estado.

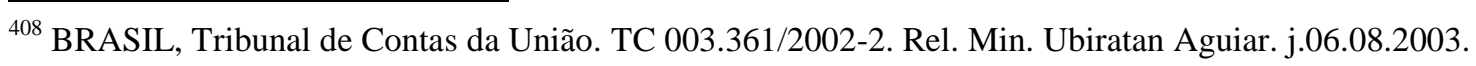




\section{SÍNTESE CONCLUSIVA.}

1. O tema: "Fiscalização financeira quanto à legitimidade", diz respeito à fiscalização incidente sobre a atividade financeira do Estado, inserindo-se, primordialmente, no âmbito do direito financeiro.

2. O tema possui status constitucional, tendo em vista que a Constituição Federal trata com detença da fiscalização das finanças públicas, estabelecendo os fundamentos básicos da matéria. Especificamente, os arts. 70 a 75 da Constituição Federal minudenciam o modo de ser do controle das contas públicas, erigindo um complexo sistema de fiscalização financeira do Estado.

3. Tal sistema indica que toda a atividade financeira do Estado está, em alguma medida, submetida ao controle. Ele institui os órgãos responsáveis pela fiscalização, explicita os sujeitos a serem sindicados, bem como elenca alguns princípios que, se observados, atestam a correção da atuação financeira. Verifica-se, nesse sentido, que a legitimidade é um dos princípios perquiridos pelo sistema de fiscalização.

4. Topologicamente, as normas constitucionais que versam sobre a fiscalização financeira encontram-se no capítulo "Do Poder Legislativo". Quis, então, o constituinte de 1988, conferir ao Poder Legislativo a competência para exercer a atividade de fiscalização financeira do Estado. Nota-se que o controle financeiro surge dentro de uma perspectiva de limitação do poder e introduz, em larga medida, o equilíbrio e a harmonia necessários à efetivação da teoria da separação dos Poderes.

5. No exercício da fiscalização financeira, o Poder Legislativo será auxiliado pelo Tribunal de Contas, conforme prescreve o art. 71 da Constituição Federal. Entretanto, cabe alertar que tal Poder não exerce a fiscalização financeira com exclusividade. $O$ controle das finanças públicas, tal como prescreve a Constituição Federal no art. 70, será exercido de duas formas distintas, podendo ser interno ou externo. O controle externo é aquele realizado pelo Poder Legislativo com o auxílio da Corte de Contas, já o controle interno é aquele perpetrado por cada Poder sobre si mesmo.

6. Na perspectiva da dualidade de controle é possível constatar que a legitimidade é aferida de modo distinto, conforme se trate do controle externo ou do controle interno. Isso porque a Constituição atribui competências e finalidades distintas a cada uma das espécies de 
controle. O Poder Legislativo leva a efeito um controle de índole política, julgando, exclusivamente, o Chefe do Poder Executivo. O Tribunal de Contas possui, por sua vez, competências privativas, sindicando e julgando qualquer pessoa que gerencie bens e valores públicos, bem como aqueles que causarem dano ao erário. Os órgãos de controle interno, de seu turno, fiscalizam os Poderes aos quais pertencem e, grosso modo, têm por finalidade apoiar a missão institucional do controle externo e realizar uma avaliação de resultados da gestão.

7. Anote-se que a fiscalização financeira quanto à legitimidade - apurada mediante controle externo e interno - não deixa de revelar algumas dificuldades. A primeira delas consiste em saber qual é a exata noção do vocábulo "legitimidade". O termo em questão é polissêmico, podendo significar a justificação do título e do exercício do poder, o que lhe dá um viés sociológico, ou, ainda, pode ser-lhe atribuído o sentido de justiça e de correção material.

8. No plano do controle financeiro, os juristas atribuem noções distintas à legitimidade prevista no art. 70 da CF de 1988. Alguns a confundem com o assentimento democrático, outros a compreendem desprovida de qualquer carga axiológica, dizendo que ela corresponde à efetiva satisfação do interesse público; ainda, há quem diga que a legitimidade conforma-se com a justiça, ou seja, a atuação financeira será legítima se for materialmente correta na medida em que desvela o bem comum.

9. Precisamente, a noção de legitimidade, no contexto da fiscalização financeira, confundese com a idéia de justiça material. Isso porque o assentimento democrático nem sempre se revela consentâneo com o bem comum. A maioria - e, também, a unanimidade - pode se perverter e assentir ao erro, razão pelo qual a vontade democrática não é um método seguro para fundamentar a legitimidade de algo. Por outro lado, não se pode negar à legitimidade um forte sentido axiológico de modo que a definição do interesse público está sujeita a uma ponderação axiológica que revela quais são as verdadeiras e indispensáveis necessidades humanas.

10. A legitimidade liga-se, ainda, à moralidade, à legalidade e à economicidade. É próprio da atuação legítima ser, outrossim, moral, na medida em que não existe correção material sem que a ação humana seja virtuosa, superando a perspectiva de mera adstrição a uma ordem objetiva formal. De outra sorte, a nova concepção de legalidade não diz respeito só à lei formal, mas também a um plexo de valores positivados que - radicados no sentido de justiça - evidenciam, tal qual a legitimidade, uma necessidade de comprovação material de 
validade. Por fim, a economicidade, ao apregoar a otimização na equação custo-benefício, revela um dever de justiça, pois em um cenário de descompasso entre recursos públicos e contingências humanas, a legitimidade só se concretiza quando se alcançam os melhores resultados ao menor custo possível.

11. Fixada a definição de legitimidade, é importante ressaltar que a fiscalização desse aspecto induz a uma celeuma que questiona a possibilidade de enfrentar o mérito administrativo. A legitimidade visa constatar a correção material da atuação estatal, confrontando, desse modo, as escolhas provenientes das faculdades discricionárias. Todavia, é importante ressaltar que a insindicabilidade do mérito administrativo não é um dogma absoluto. Comprovado o uso viciado da discricionariedade, o mérito resta contestável e passível de revisão.

12. Assim, nada impede que a fiscalização financeira quanto à legitimidade possa devassar os critérios de conveniência e oportunidade no sentido de coibir qualquer impropriedade no trato com os recursos públicos. No entanto, convém garantir que o controle desse princípio não invada as prerrogativas gerenciais da Administração, ou seja, não se pode admitir que, a pretexto de sindicar a legitimidade, os órgãos de controle interfiram nas funções privativas da Administração.

13. Logo, a fiscalização quanto à legitimidade deve compatibilizar-se com a preservação do ambiente discricionário. Tal equilíbrio é alcançado quando se debruça sobre a doutrina referente à discrição administrativa, conjugando-a com regime orçamentário e com as peculiaridades dos controles interno e externo.

14. A discricionariedade pode ser administrativa ou política. Esta última refere-se à ampla liberdade dos agentes políticos para definir a direção geral do Estado, elegendo, nesse particular, as finalidades $\mathrm{e}$ as diretrizes da atuação estatal. De seu turno, a discricionariedade administrativa é instrumental em relação à discricionariedade política, consistindo em uma margem de liberdade mais restrita para que se possa, no caso concreto, atender as finalidades ditadas no âmbito político. Ocorre, assim, que a discricionariedade política possui uma imunidade maior se comparada à administrativa e, portanto, cada qual exige um controle diferenciado.

15. A sistemática constitucional da atuação financeira do Estado recolhe essas duas espécies de discricionariedade, plasmando-as na composição institucional do regime orçamentário. A elaboração, a aprovação, a alteração e o contingenciamento do orçamento evidenciam uma notória discricionariedade política, pois por meio desse processo são 
definidos os fins e os meios adotados pela atuação financeira do Estado. Mas, uma vez vigente o orçamento, é possível vislumbrar que a sua execução acarreta o exercício de uma discricionariedade nitidamente administrativa. A concretização de muitas dotações exige uma integração discricionária por parte do gestor, possibilitando a realização do gasto. Logo, percebe-se que o regime orçamentário importa, também, em uma discricionariedade de cunho administrativo, autorizando uma esfera de liberdade para que se possa alcançar, em certos casos, as finalidades descritas no plano de gastos.

16. Assim, a fiscalização quanto à legitimidade compatibiliza-se com a discricionariedade, porque em relação às escolhas políticas se prevê um julgamento fluído, plástico e extremamente subjetivo a ser realizado pelo Legislativo. Note que a pouca objetividade desse julgamento permite uma maior imunidade quanto à eleição dos fins e dos meios da atuação financeira do Estado, preservando-se o exercício da discricionariedade política.

17. O Tribunal de Contas, porquanto se debruça sobre o quotidiano da atuação administrativa, não está habilitado, constitucionalmente, a contraditar as escolhas políticas, mas apenas a sindicar a discricionariedade administrativa. Mesmo imbuído desse mister, é fato que a Corte de Contas deve preservar as prerrogativas discricionárias da Administração, pautando-se pela prudência quando do confronto com o exercício de competências discricionárias.

18. Quanto à atuação do Chefe do Executivo, é preciso dizer que ele, normalmente, submete-se ao julgamento político do Legislativo, pois desvela, institucionalmente, a direção geral da atuação financeira do Estado. Todavia, caso o Chefe do Executivo proceda à gerência pessoal de bens e valores públicos ele deverá, eventualmente, submeter-se ao juízo do Tribunal de Contas.

19. No que tange ao controle interno, a análise de legitimidade não suscita grandes problemas. Primeiro, porque nessa espécie de controle o Poder fiscaliza suas próprias estruturas, não havendo que se preocupar com ingerências externas de um Poder sobre outro. Em segundo lugar, o controle interno é voltado, essencialmente, à análise de resultados o que importa, fatalmente, no contraste das escolhas gerenciais, pois a atuação grosseira e ineficiente deve ser revista e não mais repetida.

20. Esclareça-se, no entanto, que a fiscalização quanto à legitimidade revela algumas peculiaridades quando se controla as empresas públicas, as subvenções e as renúncias de receitas. 
21. Em relação às empresas públicas é preciso consignar que a sindicância de legitimidade não pode tolher a autonomia de mercado dessas entidades. Assim, a atividade-fim da empresa escapa a uma fiscalização mais rigorosa a ser efetuada pela Corte de Contas. Mas em relação à atividade-meio, que não influencia na estratégia empresarial junto ao ambiente de mercado, é possível defender um controle financeiro mais rígido no qual a fiscalização quanto à legitimidade permite contrastar a conveniência das escolhas realizadas pelos administradores dessas entidades.

22. As subvenções são, antes de tudo, despesas previstas no orçamento e, ostentando essa condição, é fato que os Tribunais de Contas não podem contrastar a legitimidade da previsão orçamentária de tais auxílios, sob pena de interferir em decisões políticas tomadas quando da elaboração do orçamento. Entretanto, a Corte de Contas pode avaliar a legitimidade do emprego dessas benesses financeiras pelas entidades beneficiadas, verificando o modo como são empregados os recursos públicos, bem como se as entidades possuíam condições fáticas de bem gerir os valores repassados pela via das subvenções.

23. Por fim, a aferição de legitimidade das renúncias de receitas exige que o Tribunal de Contas deixe de apreciar a procedência socioeconômica de um benefício fiscal concedido mediante lei ou por prerrogativa constitucional do Executivo. Isso porque as renúncias de receitas tributárias submetem-se a um regime de legalidade peculiar, cabendo somente aos órgãos de representação política decidir sobre a legitimidade ou ilegitimidade da concessão de benefícios tributários. Todavia, nada impede que a Corte de Contas fiscalize a renúncia de receitas certas e exigíveis. Nesse particular, o Tribunal de Contas não contradita o mérito de uma lei ou de um ato, autorizado constitucionalmente, que dispensa o recolhimento de uma obrigação pecuniária, mas constata se a Administração agiu adequadamente na persecução de um crédito certo, líquido e perfeitamente exigível. Logo, toda a renúncia de receitas exigíveis pode ser sindicada pelo Tribunal de Contas em relação à legitimidade. 


\section{REFERÊNCIAS BIBLIOGRÁFICAS.}

ALBUQUERQUE, Demóstenes Tres. O Tribunal de Contas e o controle das estatais que exploram atividade econômica. In: PEREIRA, Cláudia Fernanda de Oliveira (org.). Controle Externo: temas polêmicos na visão do Ministério Público de Contas. Belo Horizonte: Editora Fórum, 2008.

ALEXY, Robert. O conceito e validade do direito. Trad. Grecélia de Oliveira Mendes. São Paulo: Martins Fontes, 2009.

Teoria da Argumentação Jurídica: a teoria do discurso racional como a teoria da justificação jurídica. Trad. Zilda Silva. $2^{\mathrm{a}}$ ed. São Paulo: Landy Editora, 2005.

Teoria dos Direitos Fundamentais. Trad. Virgílio Afonso da Silva. São Paulo: Malheiros, 2008.

ÁLVAREZ, Tomás Prieto. La dignidad de la persona: núcleo de la moralidad y el orden públicos, límite al ejercicio de libertades públicas. Madrid: Thomson Civitas, 2001.

AMORTH, Antonio. Atti del Governo. In: AMORTH, Antonio. Scritti Giuridici: 19311939. V I. Milano: Giuffrè Editore, 1999.

APPIO, Eduardo. Controle Judicial das Políticas Públicas no Brasil. Curitiba: Juruá, 2005.

ARAUJO, Julio Cesar Manhães de. Controle da atividade administrativa pelo Tribunal de Constas na Constituição de 1988. Curitiba: Juruá Editora, 2010.

ASSONI FILHO, Sérgio. Controle de Constitucionalidade da lei orçamentária. In: CONTI, José Mauricio e SCAFF, Fernando Facury (coord.) Orçamentos Públicos e Direito Financeiro. São Paulo:RT, 2011.

. Transparência Fiscal e Democracia. Porto Alegre: Nuria Fabris, 2009.

ATALIBA, Geraldo. Extensão do conceito de bem público para efeito de controle financeiro interno e externo. Revista de Informação Legislativa, Brasília, Ano. 22, $\mathrm{n}^{\circ} 86$. p. 283/300. Abr/jun, 1985.

BALEEIRO, Aliomar. Uma introdução à ciência das finanças. Atual. Djalma de Campos. 15. ed. Rio de Janeiro: Forense, 1998. p. 454.

BANDEIRA DE MELLO, Celso Antônio. Curso de Direito Administrativo. 17 ed. São Paulo: Malheiros, 2004.

BANDEIRA DE MELLO, Celso Antonio. Discricionariedade e Controle Jurisdicional. $2^{\text {a }}$ ed., $9^{a}$ tr. São Paulo: Malheiros, 2002.

. "RELATIVIDADE" da Competência Discricionária. Revista Eletrônica de

Direito do Estado. Salvador, Instituto de Direito Público da Bahia, $\mathrm{n}^{\circ}$ 5, p. 1/10, jan/fev/mar, 2006. Disponível em: http://www.direitodoestado.com. Acesso em 13. 08.2012.

BARCELLOS, Ana Paula de. Constitucionalização das políticas públicas em matéria de direitos fundamentais: o controle político-social $e$ o controle jurídico no espaço democrático. In: SARLET, Ingo Wolfang; TIMM, Luciano Benetti (orgs.). Direitos fundamentais. Orçamento e "reserva do possível". Porto Alegre: Livraria do Advogado, 2008 . 
BARROS, Maurício. Orçamento e Discricionariedade. In: CONTI, José Mauricio e SCAFF, Fernando Facury (coord.) Orçamentos Públicos e Direito Financeiro. São Paulo:RT, 2011.

BASTIT, Michel. Dialectique et Métaphysique. In: LAMAS, Félix Adolfo. La Dialéctica Clásica: la lógica de la investigación. Buenos Aires: Instituto de Estudios Filosóficos Santo Tomás de Aquino, 2008.

BASTOS, Celso Ribeiro. Curso de Direito Constitucional. São Paulo:Celso Bastos Editora, 2002.

Curso de Direito Financeiro e Tributário. $7^{\mathrm{a}}$ ed. São Paulo: Saraiva, 1999.

BEREIJO, Alvaro Rodriguez. "Estudio preliminar". In: LABAND, Paul. "Derecho presupuestario”. Madri: Instituto de Estudios Fiscales, 1979. p. XI.

BINENBOJM, Gustavo. Da Supremacia do Interesse Público ao Dever de Proporcionalidade: um novo paradigma para o Direito Administrativo. In: SARMENTO, Daniel (org.). Interesses Públicos versus Interesses Privados: desconstruindo o princípio da supremacia do Interesse público. Rio de Janeiro: Lumen Juris, 2007.

Uma Teoria do Direito Administrativo: Direitos fundamentais, Democracia e Constitucionalização. $2^{\mathrm{a}}$ ed. Rio de Janeiro: Renovar, 2008.

BOBBIO, Norberto. O Futuro da Democracia: uma defesa das regras do jogo. $6^{\text {a }}$ ed. Rio de Janeiro: Paz e Terra.

BOBBIO, Norberto; MATTEUCI, Nicola; e PASQUINO, Gianfranco. Dicionário de Política. $7^{\text {a }}$ ed. Brasília: UNB, 1993.

BLOTTA, Vitor Souza Lima. Habermas e o Direito: da normatividade da razão à normatividade jurídica. São Paulo: Quartier Latin, 2010.

BONAVIDES. Paulo. Ciência Política. 13 ed. São Paulo: Malheiros, 2006.

BRASIL. Tribunal de Contas do Estado de São Paulo. Manual Básico - Remuneração dos Agentes Políticos Municipais. 2a ed. atual, 2007.

BRASIL. Tribunal de Contas da União. Manual de auditoria operacional / Tribunal de Contas da União. $3^{\text {a }}$ ed. Brasília: TCU, Secretaria de Fiscalização e Avaliação de Programas de Governo (Seprog), 2010.

BRASIL. Tribunal de Constas do Estado de São Paulo. Manual Básico - Remuneração dos Agentes Políticos Municipais. 2aed. atual, 2007.

BRITTO, Carlos Ayres. O Regime Constitucional dos Tribunais de Contas. Revista Diálogo Jurídico, v. I, $\mathrm{n}^{\circ} . \quad 9, \quad$ p. 1/11, dez, 2001. Disponível em: <http://www.direitopublico.com.br>. Acesso em: 17.06.2011.

BUCCI, Maria Paula Dallari. Direito Administrativo e Políticas Públicas. São Paulo: Saraiva, 2002.

BUGARIN, Paulo Soares. O Princípio da Economicidade na Jurisprudência do Tribunal de Contas da União. Belo Horizonte: Editora Fórum, 2004.

CANOTILHO, José Joaquim Gomes. Direito Constitucional. $5^{\text {a }}$ ed. Coimbra: Almedina, 1992.

CAPPELLETTI, Mauro. El control judicial de la constitucionalidad de las leys en el derecho comparado. México: Universidad Autónoma de México, 1966. 
CARDOZO, José Eduardo Martins. A Discricionariedade e o Estado de Direito. In: GARCIA, Emerson (org). Discricionariedade Administrativa. Rio de Janeiro: Lumen Juris, 2005.

CASTRO, Rodrigo Pironti Aguirre de. Sistema de Controle Interno. Disponível em: http://www.tce.to.gov.br/seminarioLRF/documento/apostila.pdf . Acesso em 28.04.2011.

CATAPANI, Márcio Ferro. A discricionariedade do Poder Executivo na elaboração do projeto de lei orçamentária anual. In: CONTI, José Mauricio e SCAFF, Fernando Facury (coord.) Orçamentos Públicos e Direito Financeiro. São Paulo:RT, 2011.

CHAVES, Francisco Eduardo Carrilho. As contas do governo da República e os Tribunais de Contas. Revista de Informação Legislativa, Brasília, Ano. 44, no 1174, p. 309/317, Abr/Jun, 2007.

CHEVALLIER, Jacques. L'État de droit. Paris: Montchrestien, 1992.

CARVALHO FILHO, José dos Santos. A Discricionariedade: análise de seu delineamento jurídico. In: GARCIA, Emerson (coord). Discricionariedade Administrativa. Rio de Janeiro: Lumen Juris, 2005.

CARVALHO, André de Castro e CONTI, José Maurício. O Controle Interno na Administração Pública Brasileira: qualidade do gasto público e responsabilidade fiscal. Direito Público. Ed. Síntese/IDP: Porto Alegre/Brasília, v. 37, p. 201/220, jan/fev, 2011.

CARVALHO JUNIOR, Clóvis de. Mérito do Ato Administrativo. Tese de Doutorado USP. São Paulo: edição do autor, 1978.

COMPARATO, Fábio Konder. $O$ poder de controle na sociedade anônima. $2^{\mathrm{a}}$ ed. São Paulo:RT, 1977.

- Sobre a Legitimidade das Constituições. In: BONAVIDES, Paulo e outros (coord.) Constituição e Democracia: estudos em homenagem ao Prof. J.J. Gomes Canotilho. São Paulo: Malheiros, 2008.

CONTI. José Maurício. A autonomia financeira do poder judiciário. São Paulo: MP editora, 2006.

1998.

Direito Financeiro na Constituição de 1988. São Paulo: Oliveira Mendes,

Iniciativa Legislativa em matéria financeira. In: CONTI, José Mauricio e SKAFF, Fernando Facury (coord). Orçamentos Públicos e Direito Financeiro. São Paulo: RT, 2011.

2008.

(coord). Orçamentos Públicos: a lei 4320 de 1964 comentada. São Paulo: RT,

CRETELLA JÚNIOR, José. Tratado de Direito Administrativo. V. II. $2^{\mathrm{a}}$ ed. Rio de Janeiro: Forense, 2002. p. 179.

D'ENTRÈVES, Alexandre Passerin. Légalité et Legitimité. p. 30. In: Annales de Philosophie Politique n.7: L'idée de Légitimité. Paris: Press Universitaires de France, 1967.

DI PIETRO, Maria Sylvia Zanella. Direito Administrativo. 22a ed. São Paulo:Atlas, 2009. Discricionariedade Administrativa na Constituição de 1988. 2 a ed. São Paulo:Atlas, 2007. 
DROMI, Jose Roberto. “Constitución, Gobierno y Control” Argentina: Ediciones Ciudad Argentina, 1983.

DWORKIN, Ronald. Equality, democracy, and constitution: we the people in Court. Alberta Law Review, n. 28, p. 324/346, 1990.

ENTERRÍA, Eduardo García de. Democracia, Jueces y Control de la administración. $5^{\text {a }}$ ed. ampl. Navarra: Thomson Civitas, 2005.

FAGUNDES, Miguel Seabra. O contrôle dos atos administrativos pelo Poder Judiciário. $4^{\mathrm{a}}$ ed. Rio de Janeiro: Forense, 1967.

. Reformas essenciais ao aperfeiçoamento das instituições políticas. Revista de Direito Administrativo, Rio de Janeiro, vol. 43, p. 9/21, jan/mar, 1956.

FARIA, José Eduardo. A definição do interesse público. In: SALLES, Carlos Alberto (org.). Processo Civil e Interesse Público. São Paulo: RT, 2003.

FARIA, Rodrigo Oliveira de. Natureza Jurídica do Orçamento e Flexibilidade Orçamentária. Dissertação de mestrado. Faculdade de Direito da USP. São Paulo: edição do autor, 2009.

FERNANDES, Jorge Ulisses Jacoby. Tomada de contas especial: processo $e$ procedimento nos Tribunais de Contas e na Administração Pública. Brasília: Brasília Jurídica, 1996.

Fórum, 2003.

. Tribunais de Constas do Brasil: jurisdição e competência. Belo Horizonte:

FERREIRA FILHO, Manoel Gonçalves. A Reconstrução da democracia. São Paulo:Saraiva, 1979.

. Curso de Direito Constitucional. 30 ed. São Paulo: Saraiva, 2003.

$\overline{\text { Saraiva, } 2010 .}$

. Princípios Fundamentais do Direito Constitucional. $2^{\mathrm{a}}$ ed. São Paulo:

FILOMENA, Márcia Mata. Fiscalização da Administração Pública em face da economicidade. RT, São Paulo, 710. p. 233/236. dez. 2004.

FRANCO SOBRINHO, Manoel de Oliveira Franco. O controle da moralidade administrativa. São Paulo: Saraiva, 1974.

FREITAS, Juarez. Discricionariedade Administrativa e o Direito Fundamental à Boa Administração Pública. $2^{\text {a }}$ ed. São Paulo: Malheiros, 2009.

FURTADO, José de Ribamar Caldas. Elementos de Direito Financeiro. Belo Horizonte: Fórum, 2009.

. O controle de legitimidade do gasto público. Fórum de Contratação e

Gestão Pública, Belo Horizonte, Ano 5, n. 54, p. 7298/7301, jun. 2006.

Os regimes de Contas Públicas: contas de governo e contas de gestão.

Revista do Tribunal de Contas da União, Brasília, n. 109, p. 61/89 mai/ago, 2007.

GIACOMONI, James. Orçamento Público. 13 ed. São Paulo: Atlas, 2007.

GIACOMUZZI, José Guilherme. A Moralidade Administrativa e a Boa-Fé da Administração Pública - o conteúdo dogmático da moralidade administrativa. São Paulo: Malheiros, 2002. 
GOMES, Emerson Cesar da Silva. Responsabilidade Financeira: uma teoria sobre a responsabilidade no âmbito dos tribunais de contas. Porto Alegres:Nuria Fabris, 2012.

GONÇAVES, Wilson. A Fiscalização financeira das entidades da administração indireta na constituição federal. Revista de Informação Legislativa. Brasília, v. 10, n.39, p. 43-50, jul/set, 1973.

GOYARD-FABRE, Simone. Os Princípios Filosóficos do Direito Político Moderno. Trad. Irene A. Partenot. São Paulo: Martins Fontes, 2002.

GUALAZZI, Eduardo Lobo Botelho. Regime Jurídico dos Tribunais de Contas. São Paulo: RT, 1992.

HABERMAS, Jürgen. Verdad y justificación. Trad. Pere Fabra e Luis Díez. Madrid: Trota, 2002.

HARADA, Kiyoshi. Cartões corporativos infringem princípios de Direito Financeiro. In: Âmbito Jurídico, Rio Grande, 2008 Disponível em: http://www.ambitojuridico.com.br/site/index.php?n_link=revista_artigos_leitura\&artig o_id=2757. Acesso em 28/06/2011.

HENRIQUES, Elcio Fiori. Os Benefícios Fiscais no Direito Financeiro e Orçamentário: o gasto tributário no direito brasileiro. São Paulo: Quartier latin, 2010.

HERNÁNDEZ DE LAMAS, Gabriela Beatriz. Dialéctica, Retórica y Educación: el método en el discurso pedagógico. In: LAMAS, Félix Adolfo. La Dialéctica Clásica: la lógica de la investigación. Buenos Aires: Instituto de Estudios Filosóficos Santo Tomás de Aquino, 2008.

HOLMES, Stephen. Precommitment and the paradox of democracy. In: ELSTER, Jon; SLAGSTAD, Rune. Constitutionalism and Democracy. Cambridge: Cambridge University Press, 1998.

HORVATH, Estevão. O Direito Tributário no contexto da atividade financeira do Estado. São Paulo: edição do autor, 2009.

LIMA, Gustavo Massa Ferreira. O Princípio Constitucional da Economicidade $e$ o Controle de Desempenho pelos Tribunais de Contas. Belo Horizonte: Fórum, 2010.

LOPES, José Reinaldo de Lima. Judiciário, democracia e políticas públicas. Brasília: Revista de Informação Legislativa, Brasília, v.31, n. 122, p. 255/265, mai/jun, 1994.

MANNARINO, Rosanne. Prestação de Contas do Governo da República. Para quem? A sociedade Brasileira?p. 230. In: SOUSA JÚNIOR, José Geraldo de (org.). Sociedade Democrática, direito público e controle externo. Brasília: TCU, 2006.

MARTINS, Fernando Rodrigues. Controle do Patrimônio Público. São Paulo: RT, 2000.

MATIAS-PEREIRA, José. Finanças Públicas: a política orçamentária no Brasil. $4^{\mathrm{a}}$ ed. São Paulo: Atlas, 2009.

MC ILWAIN, Charles Howard.. Constitucionalismo Antiguo y Moderno. Trad. José Rovira Armenegol. Buenos Aires: Editorial Nova, 1947.

MENDES, Marcos José. Sistema orçamentário brasileiro: planejamento, equilíbrio fiscal e qualidade do gasto público. Série Texto para discussão no 39. Brasília: Senado Federal, 2008.

MEIRELLES, Hely Lopes. Direito Administrativo Brasileiro. $34^{\mathrm{a}}$ ed. São Paulo: Malheiros, 2008. 
MEDAUAR, Odete. Controle da Administração Pública. São Paulo: RT, 1993.

O Direito Administrativo em Evolução. $2^{\text {a }}$ ed. São Paulo:RT, 2003.

MENDONÇA, Eduardo. Da faculdade de gastar ao dever de agir: o esvaziamento contramajoritário das políticas públicas. In: SARLET, Ingo Wolfang; TIMM, Luciano Benetti (orgs.). Direitos fundamentais. Orçamento e "reserva do possível". $2^{\mathrm{a}}$ ed. Porto Alegre: Livraria do Advogado, 2010.

MILESKI, Helio Saul. O Controle da Gestão Pública, São Paulo: RT, 2003.

MILL. John Stuart. Considerações sobre o governo representativo. Trad. Débora Ginza e Rita de Cássia Gondim. São Paulo: Editora Escala, 2006.

MIRANDA, Jorge. Manual de Direito Constitucional. Tomo II. $2^{\mathrm{a}}$ ed. Coimbra: Coimbra Ed., 2005.

2005.

Manual de Direito Constitucional. Tomo V. $2^{\mathrm{a}}$ ed. Coimbra: Coimbra Ed.,

MONCADA, Luis S. Cabral de. Estudos de Direito Público. Coimbra: Coimbra ed., 2001.

MOREIRA NETO, Diogo de Figueiredo. Moralidade Administrativa: do conceito à efetivação. Revista de Direito Administrativo, Rio de Janeiro, v. 190, p. 1/44, out./dez. 1992.

MORTATI, Costantino. L'ordinamento del Governo nel Nuovo Diritto Pubblico Italiano. Milano: Giuffré, 2000.

Legitimidade e Discricionariedade. $2^{\text {a }}$ ed. Rio de Janeiro: Forense, 1991.

MOTTA PINTO, Henrique. A autarquização das empresas estatais na jurisprudência do Supremo Tribunal Federal: um obstáculo para as reformas na administração pública. Caderno de Gestão pública e Cidadania. São Paulo, v. 15, n 57. 2010.

MÜLLER, Friedrich. "Quem é o povo? A questão fundamental da democracia”. $4^{\mathrm{a}}$ ed. São Paulo: RT, 2009.

NASCIMENTO, Rogério Soares do. A ética do discurso como justificação dos Direitos Fundamentais na obra de Jürgen Habermas. In. TORRES, Ricardo Lobo (org.). Legitimação dos Direitos Humanos. $2^{\text {a }}$ ed. Rio de Janeiro: Renovar, 2000.

NEVES, Marcelo. O novo paradigma para os órgãos de controle interno: da auditoria de conformidade (campo da legalidade) para a auditoria operacional de natureza eminentemente preventiva. Fórum de Contratação e Gestão Pública, Belo Horizonte, ano 6, n. 67, p. 40/42, jul, 2007.

OLIVEIRA, Farlei Martins Riccio de. Controle de Legitimidade de Políticas Públicas: limites e possibilidades. Atlas: Revista de Direito Administrativo, Rio de Janeiro, v. 247, p. 57-97, 2008.

OLIVEIRA, Régis Fernandes. Curso de Direito Financeiro. $2^{\mathrm{a}}$ ed. São Paulo: RT, 2008.

Fiscalização Financeira e Orçamentária. Revista de Direito Público, São Paulo, n. 96. p. 213/223. out/dez, 1990.

OHLWEILER, Leonel Pires. Políticas Públicas e controle jurisdicional: uma análise hermenêutica à luz do Estado de Direito. In: SARLET, Ingo Wolfang; TIMM, Luciano Benetti (orgs.). Direitos fundamentais. Orçamento e "reserva do possível". $2^{\mathrm{a}}$ ed. Porto Alegre: Livraria do Advogado, 2010. 
PEDERIVA, João Henrique e PONTES, João Batista. Contas prestadas pelo Presidente da República: apreciação do Congresso Nacional. Consultoria Legislativa do Senado Federal. Brasília, Textos para Discussão nº 14. Ago. 2004.

PÉREZ ROYO, Fernando. Derecho Financiero y Tributario: parte general. $20^{\mathrm{a}}$ ed. Cizur Menor: Civitas, 2010.

PINHEIRO, Luis Felipe Valerim. Orçamento Impositivo. Dissertação de mestrado. Faculdade de Direito da USP. São Paulo: edição do autor, 2007.

POLLARI, Nicolò. Scienze delle finanze. Roma: Laurus Robuffo, 1995.

RAMOS, Naimar M. Planejamento e Política Financeira do Governo. Brasília: Esaf, 1982.

REALE, Miguel. Lições Preliminares de Direito. 26 ed. São Paulo: Saraiva, 2002.

REZENDE, Fernando. Finanças Públicas. 2a ed. São Paulo: Atlas, 2007.

SESIN, Domingo. Administración Pública: actividad reglada, discrecional y técnica. Buenos Aires: Deopalma, 1994.

SCHUMPETER, Joseph Alois. Capitalismo, socialismo e democracia. Trad. Ruy Jungmann. Rio de Janeiro: Ed. Fundo de Cultura, 1961.

SCLIAR, Wremyr. Controle externo brasileiro: Poder Legislativo e Tribunal de Contas. Revista de Informação Legislativa, Brasília, Ano. 46, nº 181, p. 249/274. jan/mar, 2009.

SHAKESPEARE, William. Júlio César. Ato III. Cena II. Trad. Carlos Lacerda. $2^{\text {a }}$ ed. Rio de Janeiro: Bibliex, 1992.

SILVA, Alexandre Garrido da. Direitos Humanos, Constituição e Discurso da Legitimação: Possibilidades e Limites da Teoria do Discurso. In. TORRES, Ricardo Lobo (org.). Legitimação dos Direitos Humanos. $2^{\mathrm{a}}$ ed. Rio de Janeiro: Renovar, 2000.

SILVA, José Afonso. Curso de Direito Constitucional Positivo. 23 ed. São Paulo: Malheiros, 2005.

. Orçamento-programa no Brasil. São Paulo:RT, 1973.

SILVA, Virgílio Afonso da. A constitucionalização do Direito: os direitos fundamentais nas relações entre particulares. São Paulo: Malheiros, 2008.

SOUZA, Celina. Construção e consolidação de instituições democráticas: papel do orçamento participativo. In: São Paulo Perspectiva, São Paulo, v. 15, n. 4, dez. 2001.

Disponível em <http://www.scielo.br/scielo.php?script=sci_arttext\&pid=S010288392001000400010\&lng $=$ pt\&nrm=iso $>$. Acesso em: 22. 06.2011.

SOUZA, Rodrigo Pagani. O controle estatal das transferências de recursos públicos para o terceiro setor. Tese de Doutorado. Faculdade de Direito da USP. São Paulo: edição do autor, 2009.

SPADARO, Antonino. "Contributo per una Teoria della Costituzione: fra democrazia relativista e assolutismo etico". V. I. Milano: Giufré, 1994.

STERNBERGER. Dolf. Typologie de la Légitimité. In: Annales de Philosophie Politique n.7: L'idée de Légitimité. Paris: Press Universitaires de France, 1967.

TÁCITO, Caio. A moralidade administrativa e a nova lei do Tribunal de Contas da União. Revista de Direito Administrativo, Rio de Janeiro, vol. 190, p. 45/53, out/nov, 1992. 
TOLLINI, Helio. Em busca de uma participação mais efetiva do Congresso Nacional no processo de elaboração orçamentária. Brasília: Biblioteca Digital da Câmara dos Deputados, 2008.

TORRES, Ricardo Lobo, Curso de Direito Financeiro e Tributário. 8. ed. Rio de Janeiro: Renovar, 2001.

. Tratado de Direito Constitucional Financeiro e Tributário: o orçamento na Constituição, v. 5. $3^{\text {a }}$ ed. Rio de Janeiro: Renovar, 2000.

VILLEY, Michel. O direito e os direitos humanos. Trad. Maria Ermantina de Almeida Prado Galvão. São Paulo: Martins Fontes, 2007.

Filosofia do Direito: definições e fins do direito, os meios do direito. Trad. Márcia Martinez de Aguiar. São Paulo:Martins Fontes, 2003.

VIVES, Francesc Vallés. El control externo del gasto público: configuración y garantía constitucional Madrid:Centro de Estudios Políticos y Constitucionales, 2003.

WEBER, Max. Economia e Sociedade: fundamentos da Sociologia Compreensiva. V.1. $3^{\mathrm{a}}$ ed. Brasília: UNB, 1994

\section{JULGADOS.}

BRASIL. Supremo Tribunal Federal. MS 25092/DF. Rel. Min. Carlos Velloso. j. 10.11.2005.

BRASIL. Tribunal de Contas da União. TC - 009.569/2005-3. Rel. Min. Benjamin Zymler. j. 20.09.2005.

BRASIL. Tribunal de Contas da União. TC - 012.060/2004-4. Rel. Min. Benjamin Zymler. j. 25.07.2005.

BRASIL. Supremo Tribunal Federal. ADI 1779/PE. Rel. Min. Ilmar Galvão, j.01.08.2001.

BRASIL. Supremo Tribunal Federal. ADI 1964/ES - MC. Rel. Min. Sepúlveda Pertence. 25.03. 1999.

BRASIL. Supremo Tribunal Federal. ADI 261-9/SC. Rel. Min. Gilmar Mendes, j.14.11.2002.

BRASIL. Supremo Tribunal Federal. ADI 261-9/SC - MC. Rel. Min. Gilmar Mendes, j.26.05.2006.

BRASIL. Supremo Tribunal Federal. MS 24353-8/DF. Rel. Min. Ellen Gracie, j.20.02.2003.

BRASIL. Supremo Tribunal Federal. ADI 23919-1/DF. Rel. Min. Carlos Velloso, j.24.10.2002.

BRASIL. Supremo Tribunal Federal. MS 21644-1/DF. Rel. Min. Néri da Silveira. j. 04.11.1993.

BRASIL. Supremo Tribunal Federal. ADI 1934-7/DF-MC. Rel. Min. Moreira Alves. j. 01.09.1999. 
BRASIL. Supremo Tribunal Federal. MS 224312-2/DF. Rel. Min. Hellen Gracie. j. 19.02.2003.

BRASIL. Superior Tribunal de Justiça. Resp. 429.570/GO. Rel. Min. Eliana Calmon. J. 22.03. 2004.

BRASIL. Supremo Tribunal Federal. ADI 4048/DF-MC. Min. Gilmar Mendes. j. 22.08.2008.

BRASIL. Tribunal de Contas da União. TC - 012.484/2007-2. Rel. Benjamin Zymler. j. 14. 11. 2007.

BRASIL. Tribunal de Contas da União. TC - 018.771/2009-4. Rel. Ana Arraes. j. 16. 11. 2011.

BRASIL. Supremo Tribunal Federal. MS 25888 DF- MC. Rel. Min. Gilmar Mendes. j. 23.03. 2006.

BRASIL. Tribunal de Contas da União. TC 009.647/2009-4. Rel. Raimundo Carreiro. j. 14.10. 2009.

BRASIL. Supremo Tribunal Federal. MS 24328/DF. Rel Min. Ilmar Galvão. j. 06.12.2002.

BRASIL. Superior Tribunal de Justiça. MS 13499/CE-RO. Rel. Min. Eliana Calmon, $2^{\mathrm{a}}$ turma. j. 13.08.2002.

BRASIL. Supremo Tribunal Federal. MS 23875/DF e MS 23627/DF. Rel. Min. Carlos Velloso. j. 07.03.2002.

BRASIL. Supremo Tribunal Federal. MS 25181/DF. Rel. Min. Marco Aurélio. j. 10.11.2005.

BRASIL. Supremo Tribunal Federal. MS 25092/DF. Rel. Min. Carlos Velloso. j. 10.11.2005.

BRASIL. Tribunal de Contas da União TC 008.450/2002-7. Rel. Min. Adylson Motta. j. 30.07.2003.

BRASIL. Tribunal de Contas do Estado de São Paulo. TC- 2297/026/09. Rel. Robson Marinho. j. 20.10.2010.

BRASIL. Supremo Tribunal Federal. MS 21644/DF. Rel. Min. Néri da Silveira. j. 08.11.1996.

BRASIL, Tribunal de Contas da União. TC 003.361/2002-2. Rel. Min. Ubiratan Aguiar. j.06.08.2003. 